\title{
RYNEK KAPITAŁOWY WOBEC WYZWAŃ DEKONIUNKTURY
}

redakcja naukowa Teresa Czerwińska i Alojzy Z. Nowak

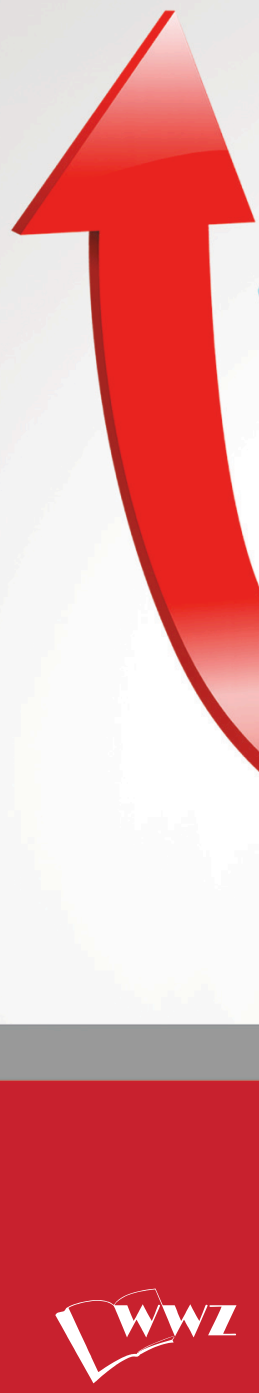

Wydawnictwo Naukowe

Wydziału Zarzadzania

$70 \%$

$100 \%$

Uniwersytetu Warszawskiego

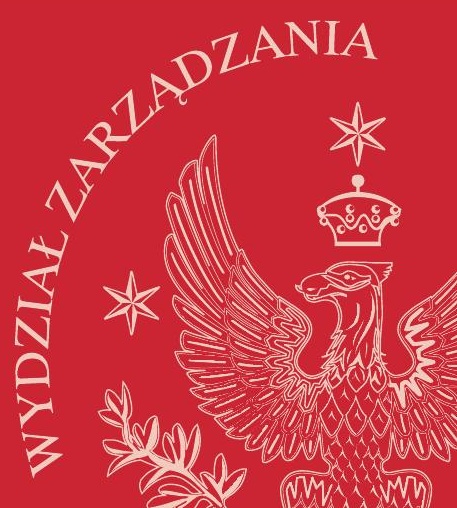


RYNEK KAPITAKOWY WOBEC WYZWAŃ DEKONIUNKTURY 



\section{RYNEK KAPITAKOWY WOBEC WYZWAŃ DEKONIUNKTURY}

REDAKCJA NAUKOWA:

TERESA CZERWIŃSKA AlojzY Z. NOWAK

WARSZAWA 2014

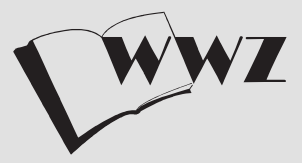

Wydawnictwo Naukowe Wydziału Zarządzania Uniwersytetu Warszawskiego 
Recenzent naukowy: prof. nzw. dr hab. Teresa Czerwińska prof. dr hab. Andrzej Gospodarowicz prof. dr hab. Marian Górski dr hab. Sebastian Majewski prof. dr hab. Alojzy Z. Nowak dr Iwona Sroka prof. dr hab. Jan Turyna prof. dr hab. Małgorzata Zaleska

Redakcja: Anita Sosnowska

Projekt okładki: Agnieszka Miłaszewicz

(C) Copyright by Wydawnictwo Naukowe Wydziału Zarządzania Uniwersytetu Warszawskiego, Warszawa 2014

ISBN: 978-83-63962-51-7

ISBN: 978-83-63962-52-4 (on line)

DOI: 10.7172/2014.wwz.6

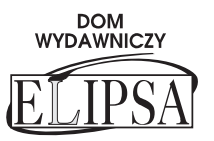




\section{Spis treści}

Rynek kapitałowy $w$ okresie dekoniunktury - wprowadzenie

(Teresa Czerwińska, Alojzy Z. Nowak)

\section{CZĘŚ́́ I}

\section{TENDENCJE ROZWOJU RYNKU KAPITAŁOWEGO}

\section{ROZDZIAE I}

Zastosowanie koncepcji zarządzania wartościa $w$ największych spótkach notowanych na GPW $w$ Warszawie (Dariusz Zarzecki) ............ 19

ROZDZIAE II

Pozytywistyczny paradygmat wartości (Katarzyna Włodarczyk)........ 33

ROZDZIAE III

Asymetria informacji na giełdowym rynku akcji - raportowanie danych pozafinansowych przez spótki publiczne na Gietdzie Papierów Wartościowych $w$ Warszawie (Teresa Czerwińska) ................ 49

ROZDZIAE IV

Katastroficzne instrumenty pochodne - stan rynku i perspektywy rozwoju (Agnieszka Majewska) . ...................... 70

RozDZIAE V

Determinanty raportowania transakcji podejrzanych przez sektor bankowy (Patrycja Chodnicka)...................... 86

ROZDZIAt VI

Rola repozytoriów transakcji $w$ zwiększeniu transparentności rynku derywatów (Iwona Sroka) . . . . . . . . . . . . . . . . . . . 100

ROZDZIAE VII

Niski poziom alfabetyzacji finansowej spoteczeństwa jako bariera ograniczająca rozwój rynku kapitałowego (Bożena Frączek). 


\section{CZĘŚ́́ II}

\section{MODELOWANIE ZJAWISK NA RYNKU KAPITALOWYM W WARUNKACH NIEPEWNOŚCI I RYZYKA}

\section{ROZDZIAE VIII}

Ryzyko rynku akcji międzynarodowych rynków giełdowych (Alojzy Z. Nowak, Tadeusz Winkler-Drews)............................... 135

ROZDZIAE IX

Zastosowanie rozktadu NIG $w$ modelowaniu danych finansowych przy wykorzystaniu dodatkowych informacji o cenach minimalnych $i$ maksymalnych (Grzegorz Perczak) . . . . . . . . . . . . . . . . . 159

ROZDZIAE X

Wplyw informacji nieekonomicznych na ksztattowanie się kursów akcji spótek prowadzących dziatalność sportowa (Sebastian Majewski)....... . 179

ROZDZIAE XI

Rynkowe wykorzystanie kointegracji - osiaganie absolutnych stóp zwrotu $z$ kontraktów futures notowanych na GPW w Warszawie (Piotr Jaworski, Hubert Wiśniewski)

\section{ROZDZIAE XII}

Niestabilność wspótczynnika beta $w$ sektorze finansowym - analiza dla wybranych rynków europejskich (Renata Karkowska, Katarzyna Niewińska)

RozDZIAE XIII

Ocena efektywności strategii inwestycji społecznie odpowiedzialnych na przyktadzie wyników polskich funduszy inwestycyjnych (Tomasz Jedynak). 


\section{Rynek kapitałowy w okresie dekoniunktury - wprowadzenie}

Realia kryzysu ogólnogospodarczego oraz pogarszająca się kondycja finansów publicznych wielu krajów stawia zagadnienie rozwoju i roli rynku kapitałowego w gospodarce w nowym świetle. Coraz silniej akcentuje się znaczenie transparentności rynku, standardów bezpieczeństwa zawierania i rozliczania transakcji oraz raportowania danych pozafinansowych w kontekście zaufania do mechanizmu rynku kapitałowego, które - jak podkreśla wielu ekspertów - jest kluczowym czynnikiem jego rozwoju. Kryzys zadłużenia w sferze finansów publicznych oraz niepewne perspektywy rozwoju koniunktury gospodarczej, nie tylko w krajach Unii Europejskiej, stanowią podstawowe źródło znacznego wzrostu poziomu ryzyka na rynku kapitałowym, gdzie, jak wspomniano, zaufanie jest kwestią zasadniczą. Inwestorzy są świadkami często precedensowego obniżania ratingów papierów wartościowych dotychczas uznawanych za tzw. risk free.

Wzajemne powiązania rynku kapitałowego z gospodarką są niezwykle złożone i wielokierunkowe. Coraz częściej podnoszona jest kwestia finansyzacji gospodarki (zob. Ratajczak 2012), pada pytanie: czy Wall Street rządzi Main Street? Jak wykazują badania, w obecnych realiach gospodarczych strumień przepływów finansowych wielokrotnie przewyższa strumienie przepływów realnych. Obserwujemy pewne uniezależnienie tych dwóch strumieni. Szacuje się, że przepływy strumieni pieniężnych na współczesnych rynkach finansowych tylko w ok. $10 \%$ dotyczą realnych procesów gospodarowania. Stąd coraz częściej mówimy o „kasynie kapitalizmu” (Sopoćko 2012), większość transakcji ma bowiem charakter spekulacyjny.

Niewątpliwie znaczny rozwój instrumentów i innowacji finansowych przyczynił się do pewnego rozerwania między rynkiem kapitałowym a realną 
gospodarką, nasiliło się zjawisko moral hazard związane z dynamicznym rozwojem instytucji pośrednictwa finansowego oraz potęgowaniem problemu agencji, zwłaszcza w strukturach instytucji o charakterze konglomeratowym. Zjawiska te powodują, że sprzężenia zwrotne między rynkiem kapitałowym a realną gospodarką są trudniej przewidywalne. Zarówno w literaturze przedmiotu, jak i praktyce przeważa pogląd o implikacji zmienności koniunktury giełdowej przez cykl koniunkturalny gospodarki narodowej. Powiązania między cyklem koniunkturalnym występującym w gospodarce a cyklem giełdowym są na tyle istotne, że wykształcił się cały nurt badawczy zajmujący się prognozowaniem koniunktury giełdowej w oparciu o sygnały płynące z gospodarki. Rynek kapitałowy jest bowiem silnie powiązany tak z gospodarką krajową, jak i międzynarodową, a fluktuacja koniunktury na rynku giełdowym jest wypadkową wielu czynników mających swoje źródło w czynnikach makrogospodarczych, sektorowych i politycznych.

Istotne znaczenie dla powstawania nowych paradygmatów na rynku finansowym w odpowiedzi na globalny kryzys finansowy ma ewolucyjna zmiana percepcji zarządzania procesem inwestycyjnym, dotycząca przede wszystkim kryteriów selekcji instrumentów do portfela inwestycji oraz analizy i oceny jego efektywności. Rozwój współczesnej teorii finansów opiera się w zasadzie na utylitaryzmie szkoły neoklasycznej, która kładzie nacisk na racjonalność zachowań inwestora, efektywność wyceny i alokacji kapitału w systemie rynkowym. Stąd koncepcja klasyczna ujmuje parametry portfela inwestycji w kategoriach ryzyko-zwrot. Implementacja zaś koncepcji społecznej odpowiedzialności na rynku kapitałowym wymaga poszukiwania rozwiązań umożliwiających łączenie celów typowo biznesowych z celami społecznymi na gruncie praktyki. Jest to, jak się wydaje, właściwy kierunek poszukiwań w odpowiedzi na nowe wyzwania w globalnej ekonomii, o czym przekonuje laureat Nagrody Nobla Joseph Stiglitz: spotecznie odpowiedzialne inwestowanie to prawdopodobnie najważniejszy i najbardziej pomyślny kierunek rozwoju nowoczesnego zarzadzania aktywami (High Net Worth Individuals and Sustainable Investment 2010). Wartość rynku społecznie odpowiedzialnych inwestycji (Social Responsible Investment) w krajach Unii Europejskiej po wystąpieniu kryzysu ekonomicznego w latach 2007-2009 wzrosła o ponad 87\% (European SRI Study 2010). Rozwój koncepcji SRI nie tylko dał początek redefiniowaniu kryteriów selekcji aktywów do portfela inwestycji, lecz także przyczynił się do wykształcenia się odrębnych strategii inwestycyjnych, które zmieniły klasyczne postrzeganie zarządzania procesem inwestycyjnym.

Stan polskiego rynku kapitałowego odzwierciedla sytuację krajową, związaną przede wszystkim ze spowolnioną koniunkturą gospodarczą, 
niską dynamiką eksportu, trudną sytuacją finansów publicznych, znacznym wyhamowaniem inwestycji publicznych, a także w znacznej mierze problemy, z którymi boryka się cała Unia Europejska. Nawiązując do hipotezy efektywności rynku kapitałowego, sformułowanej przez noblistę Eugene'a Famę, można stwierdzić, że na rynku kapitałowym, jak w soczewce, skupiają się nierozwiązane problemy gospodarcze. W monografii przedstawiano zjawiska zachodzące na rynku kapitałowym w dwóch głównych obszarach: sensu stricto - instrumentarium modelowania zjawisk na rynku kapitałowym w warunkach niepewności i ryzyka oraz pomiaru i oceny efektywności oraz sensu largo - podejście w wymiarze makro dotyczące obserwowanych trendów i powstawania nowych paradygmatów w „pokryzysowych” realiach rynku kapitałowego i jego otoczeniu instytucjonalnym. Podstawowym celem naukowym monografii jest przedstawienie głównych nurtów wielowątkowej dyskusji w zakresie rozwoju rynku kapitałowego w okresie ogólnej dekoniunktury oraz przegląd wyników badań prowadzonych w środowisku naukowym.

W pierwszej części monografii analizie poddano wybrane zjawiska i tendencje rozwojowe rynku kapitałowego. Przedmiotem rozważań jest paradygmat kreowania i zarządzania wartością, co jest w pewnym sensie signum temporis współczesnych rynków finansowych (zob. rozdz. 2. Katarzyna Włodarczyk, Pozytywistyczny paradygmat wartości). Koncepcja Value Based Management i wielorakie aspekty jej zastosowania wciąż są przedmiotem dyskusji, a teza, że niewłaściwa aplikacja tej koncepcji stała się jedną z głównych przyczyn trudności finansowych i upadku firm, tj.: Enron, Worldcom, Parmalat wydaje się być zasadna. Jak wykazują badania przeprowadzone w grupie 50 największych pod względem kapitalizacji spółek publicznych notowanych na GPW, prawie 1/5 zarządzających największymi spółkami publicznymi w Polsce nie zna koncepcji VBM, a blisko 48\% spółek, których przedstawiciele udzielili odpowiedzi, wykorzystuje VBM w zarządzaniu firmą (zob. rozdz. 1. Dariusz Zarzecki, Zastosowanie koncepcji zarzadzania wartościa w największych spótkach notowanych na GPW w Warszawie). Wdrożenia systemu VBM przedsiębiorstwa te dokonały relatywnie niedawno (dopiero po 2003 roku). Niemniej jednak 76,9\% badanych spółek deklaruje wolę wdrożenia i stosowania VBM w przyszłości. Zatem, w świetle obowiązującego prowartościowego paradygmatu nauk o zarządzaniu, pojawia się potrzeba wnikliwych badań w zakresie konsekwencji zastosowania VBM w spółkach publicznych.

Niezwykle istotną rolę w rozwoju rynku kapitałowego odgrywa transparentność mechanizmów jego funkcjonowania, przejrzystość oraz ograniczanie 
asymetrii informacyjnej. Niski poziom wiedzy w zakresie rynku kapitałowego jest czynnikiem potęgującym zjawisko asymetrii informacyjnej i przyczynia się do spowolnienia rozwoju rynku kapitałowego (zob. rozdz. 7. Bożena Frączek, Niski poziom alfabetyzacji finansowej spoteczeństwa jako bariera ograniczająca rozwój rynku kapitatowego). Poziom asymetrii informacyjnej na współczesnym rynku kapitałowym zdeterminowany jest w znacznym stopniu transparentnością emitentów w zakresie raportowania danych pozafinansowych (Environment, Social, Corporate Governance - ESG). Wprowadzane na wysoko rozwiniętych rynkach regulacje w zakresie raportowania danych pozafinansowych mają na celu zwiększyć transparentność, obliczalność działalności spółek, co z kolei przyczynia się w znaczącym stopniu do redukcji asymetrii informacyjnej, a w konsekwencji, istotnie redukuje błędy prognostyczne w zakresie ryzyko - dochód portfeli inwestycji oraz oznacza większą stabilność rynku, redukuje zjawisko szoków cenowych. W części krajów UE raportowanie danych pozafinansowych jest już pewnym standardem. Transparentność rynku w zakresie ujawniania danych pozafinansowych umożliwia kompletną holistyczną ocenę ryzyka przedsiębiorstwa i wycenę jego wartości (zob. rozdz. 3. Teresa Czerwińska, Asymetria informacji na giełdowym rynku akcji - raportowanie danych pozafinansowych przez spótki publiczne na Gietdzie Papierów Wartościowych w Warszawie).

Zwiększenie transparentności funkcjonowania rynku jest kluczowe, zwłaszcza w kontekście wypracowywania mechanizmów kontrolnych i samoregulacji rynków finansowych w pokryzysowych realiach gospodarczych. W tym aspekcie niezwykle istotne jest zapewnienie transparentności bardzo dynamicznego, spekulacyjnego rynku derywatów (zwłaszcza rynku over-the-counter - OTC), który jako nieregulowany rynek pozagiełdowy w zasadzie wymknął się spod kontroli organów nadzorczych, co przyczyniło się w znacznej mierze do obecnego kryzysu. Nieregulowany pozagiełdowy rynek derywatów odgrywa istotną rolę w zarządzaniu ryzykiem związanym z czynnikami stricte gospodarczymi oraz wynikającym ze zmian pogodowych, katastrof naturalnych, tzw. rynek katastroficznych instrumentów pochodnych (głównie: rynek obligacji katastroficznych oraz Industry Loss Warranties - ILWs). Rynek ten umożliwia transfer ryzyka ubezpieczeniowego na rynek kapitałowy w związku z rosnącymi stratami spowodowanymi zdarzeniami ekstremalnymi w krajach wysoko rozwiniętych, co przyczynia się do zwiększenia pojemności rynku ubezpieczeniowego oraz zmniejszenia kosztów reasekuracji. Jak wykazują badania, czynnikami decydującymi o dynamicznym rozwoju rynku katastroficznych instrumentów pochodnych są: zwiększanie się liczby zdarzeń katastroficznych 
oraz rosnący udział ubezpieczonych w stratach w wyniku zajścia zdarzeń ekstremalnych w krajach wysoko rozwiniętych. (zob. rozdz. 4. Agnieszka Majewska, Katastroficzne instrumenty pochodne - stan rynku i perspektywy rozwoju).

Zwiększeniu transparentności rynku derywatów ma służyć wdrożenie repozytoriów transakcji, które zapewnią gromadzenie i przetwarzanie danych o rynku derywatów w jednej bazie danych. Powszechne wprowadzenie międzynarodowych zaleceń dotyczących wdrażania repozytoriów transakcji, odpowiednie ich umocowanie w systemie prawnym danego państwa oraz późniejsza współpraca repozytoriów w kwestii wymiany informacji, wymagają przejścia wieloetapowego procesu, który potrwa zapewne jeszcze kilka lat (zob. rozdz. 6. Iwona Sroka, Rola repozytoriów transakcji w zwiększeniu transparentności rynku derywatów). Niemniej jednak proces ten nie tylko przyczyni się do wzrostu transparentności rynku OTC, lecz także zapewni większą efektywność kontroli organów nadzorczych.

Obok obowiązku raportowania międzynarodowe regulacje wprowadzają także wiele innych wymogów ostrożnościowych, związanych z funkcjonowaniem rynków finansowych, co przyczyni się do wzrostu bezpieczeństwa uczestników tego rynku i pozwoli łagodzić potencjalne szoki i kryzysy. Dotyczy to przede wszystkim istotnych systemowo instytucji finansowych, tj. banków i zakładów ubezpieczeń. Istotnym elementem zapewnienia transparentności rynku finansowego, obok wdrażania nowych standardów w zakresie płynności, wypłacalności oraz mechanizmów samoregulacji i kontroli, jest również przeciwdziałanie zjawiskom związanym z korupcją, manipulacją oraz praniem pieniędzy. Zjawisko prania pieniędzy na rynkach finansowych dotyczy głównie banków. To banki monitorują oraz raportują znaczną większość transakcji podejrzanych o pranie pieniędzy (od 60 do 99\% wszystkich raportowanych transakcji w różnych krajach) (zob. rozdz. 5. Patrycja Chodnicka, Analiza czynników ryzyka zjawiska prania pieniędzy w bankach). Jak wykazują badania, istotny wpływ na liczbę transakcji podejrzanych o pranie pieniędzy raportowanych przez banki ma rozmiar sektora bankowego. Naturalnym środowiskiem dla prania pieniędzy w przypadku dużych organizacji są międzynarodowe centra finansowe. Wysoko rozwinięty sektor usług finansowych jest czynnikiem wpływającym pozytywnie na napływ środków pieniężnych pochodzących z pierwotnej działalności niezgodnej z prawem. Umiędzynarodowienie usług finansowych wymaga stosowania bardziej restrykcyjnych regulacji w tym zakresie. W krajach, które zaimplementowały przepisy dotyczące zapobiegania praniu pieniędzy istnieje obowiązek rejestrowania transakcji ponadprogowych oraz natychmiastowego zgłaszania transakcji 
podejrzanych organom nadzoru (Dyrektywa 2005/60 WE Parlamentu Europejskiego i Rady).

W drugiej części monografii przedmiotem badań jest modelowanie zjawisk na rynku kapitałowym w warunkach niepewności i ryzyka. Dynamiczne środowisko rynku kapitałowego wymaga stałego poszukiwania i rozwijania instrumentarium identyfikacji i kwantyfikacji ryzyka. W tym aspekcie istotne znaczenie mają badania znajdujące się w nurcie poszukiwań możliwości zwiększenia dokładności prognozowania zmiennych finansowych z wykorzystaniem również modeli heteroskedastyczności warunkowej $(\mathrm{G})$ ARCH i metod wywodzących się z teorii zdarzeń ekstremalnych (Extreme Value Theory), co ma istotne znaczenie zwłaszcza dla coraz bardziej popularnych w instytucjach finansowych metod kwantyfikacji ryzyka typu VaR. Warta zastanowienia jest propozycja wykorzystania cen minimalnych i maksymalnych w estymacji modeli, ponieważ dzięki temu zjawiska szokowe mają bardziej krótkotrwały wpływ na zmienność niż wynikałoby to z modelu GARCH szacowanego na podstawie wyłącznie cen zamknięcia, co jest w wyraźnej opozycji do wyników uzyskiwanych np. na podstawie zmienności implikowanej (zob. rozdz. 9. Grzegorz Perczak, Zastosowanie rozktadu $N I G$ w modelowaniu danych finansowych przy wykorzystaniu dodatkowych informacji o cenach minimalnych i maksymalnych). Co prawda instytucje finansowe w kwantyfikacji ryzyka $\mathrm{z}$ wykorzystaniem VaR preferują obecnie modele warunkowe, aby uniknąć niepożądanych częstych zmian w limitach tolerowanego ryzyka. Niemniej propozycja jest ciekawa i warta prowadzenia dalszych badań empirycznych, zastosowanie bowiem proponowanego rozkładu z wykorzystaniem cen minimalnych i maksymalnych może przyczynić się do istotnych zmian w limitach podejmowanego przez instytucje ryzyka.

Globalizacja i integracja światowych rynków finansowych skutkuje wzrostem poziomu ryzyka rynkowego. Problematyka ta jest niezwykle ważna i aktualna, tym bardziej że wzajemne powiązania rynków finansowych generują pewien ciąg zależności, które należy rozpatrywać zarówno z punktu widzenia przyczyn (czynniki ryzyka), jak i konsekwencji dla całego systemu gospodarczego. Niezwykle istotne w tym kontekście są powiązania i współzależności między poszczególnymi rodzajami ryzyka, co z jednej strony powoduje pojawianie się dodatkowych rodzajów ryzyka, z drugiej zaś - w znacznym stopniu komplikuje jego identyfikację, pomiar oraz prognozowanie natężenia i zakresu możliwych skutków realizacji. Jak wykazują badania w zakresie poziomu ryzyka rynku akcji największych światowych giełd, tj.: NYSE, LSE, Euronext, Deutsche Börse oraz Tokyo SE, najwyższy 
poziom ryzyka względnego realnych stóp zwrotu (mierzony relacją odchylenia standardowego rozkładu realnych stóp zwrotu do stopy zwrotu) indeksu FTSE osiągają w krótkim horyzoncie czasowym (od 1 do 5 lat). W dłuższych horyzontach najwyższe wartości ryzyka względnego osiąga indeks CAC 40. Poziom ryzyka względnego indeksu DAX jest najniższy dla wszystkich analizowanych horyzontów inwestycyjnych (zob. rozdz. 8. Alojzy Z. Nowak, Tadeusz Winkler-Drews, Ryzyko rynku akcji międzynarodowych rynków gietdowych). Istotne długoterminowe współzależności można zaobserwować również na rynku kontraktów terminowych. Jak wykazują badania, występuje istotna statystycznie zależność między cenami kontraktów terminowych notowanych na Giełdzie Papierów Wartościowych w Warszawie (kointegracja między cenami derywatów). Istnieje równowaga pomiędzy cenami kontraktów terminowych na akcje wchodzące w skład indeksu WIG20 a derywatami na niego (zob. rozdz. 11. Piotr Jaworski, Hubert Wiśniewski, Rynkowe wykorzystanie kointegracji - osiaganie absolutnych stóp zwrotu z kontraktów futures notowanych na GPW warszawie).

Pomiar ryzyka oraz identyfikacja parametrów i determinantów jego fluktuacji w różnych fazach cyklu koniunktury giełdowej są bardzo istotne w warunkach zmienności koniunktury oraz szoków cenowych na rynkach finansowych. Doświadczenia pokazują, że pomiar ryzyka rynkowego nastręcza trudności, a jego mierniki są przedmiotem krytyki i ciągłej ewaluacji w procesie doboru instrumentarium zarządzania ryzykiem. Dyskusja ta jest tym bardziej potrzebna, że, jak wykazał globalny kryzys gospodarczy, obecne metody pomiaru i kontroli ryzyka, w tym kredytowego i rynkowego, nie zapobiegają bankructwom instytucji finansowych. Badania wykazują, że inwestorzy mają tendencje do niedoszacowywania ryzyka systematycznego w okresie hossy giełdowej. W przypadku napływu negatywnych informacji z giełdy, stopy zwrotu spółek finansowych reagują silniej, niż wynikałoby to z wartości klasycznej miary ryzyka - współczynnika beta, co oznacza, że w fazie spadków spółki finansowe traciły więcej niż w fazie wzrostów (zob. rozdz. 12. Renata Karkowska, Katarzyna Niewińska, Niestabilność wspótczynnika beta $w$ sektorze finansowym - analiza dla wybranych rynków europejskich). Biorąc pod uwagę możliwości predykcji wrażliwości cen walorów na zmiany rynkowe na rynku giełdowym ważne staje się testowanie relacji pomiędzy współczynnikami beta w kolejnych okresach, ponieważ:

1) zmienność współczynników beta jest wypadkową zarówno czynników charakterystyk rynkowych, jak i parametrów fundamentalnych spółki;

2) współczynnik beta w każdym okresie jest obciążony pewnym błędem losowym, co determinuje trafność prognoz. 
Współczynniki beta portfeli są mniej obciążone błędem i wykazują większą stabilność w czasie, a prognozowanie na ich podstawie jest bardziej dokładne. Zaobserwować można również zróżnicowanie stabilności współczynnika beta w zależności od stopnia rozwoju rynku kapitałowego, a mianowicie większą niestabilność na rynkach zaliczanych do emerging markets, tj.: w Polsce, Czechach oraz większą stabilność bet na rynkach dojrzałych. Przyczyna zróżnicowania współczynnika beta może mieć związek tak ze stopniem rozwoju rynku kapitałowego, jak i zróżnicowaniem stosowanych strategii inwestycyjnych. Stąd pojawia się pytanie o wpływ stosowanych strategii inwestycyjnych na profil ryzyko-zwrot portfela inwestycji, zwłaszcza w kontekście wspomnianych nowych paradygmatów zarządzania portfelem polegających na stosowaniu strategii społecznie odpowiedzialnych. Brakuje jak dotychczas bezspornych dowodów na pozytywne oddziaływanie aplikacji kryteriów ESG na efektywność portfela inwestycji (zob. Demystifying Responsible Investment Performance 2007). Z przyczyn obiektywnych, z jednej strony wynika to z niezwykłej złożoności samego przedmiotu badań, niedostatecznej ilości i jakości szeregów czasowych, trudności w kwantyfikacji tzw. miękkich aspektów zarządzania portfelem inwestycji oraz problemów natury metodologicznej. Z drugiej natomiast - bardzo istotne są bariery związane $\mathrm{z}$ paradygmatami $\mathrm{w}$ środowisku zarządzających oraz inwestorów, zwłaszcza: tzw. krótkowzroczność - krótkoterminowa (często kwartalna) perspektywa postrzegania wyników przedsiębiorstw i oceny wyników zarządzania portfelem inwestycji oraz bariery o charakterze mentalnym. W świetle klasycznej teorii portfelowej oraz hipotezy rynku efektywnego, konstrukcja portfela z uwzględnieniem kryteriów ESG może skutkować obniżeniem efektywności portfela inwestycji w długim okresie. W warunkach efektywnego rynku bowiem, efektywność portfela rynkowego przewyższa wszystkie inne skonstruowane portfele (w tym również portfele tworzone $\mathrm{z}$ wykorzystaniem kryteriów ESG) (Kekäläinen 2004). Stąd, im bardziej efektywny jest rynek kapitałowy, tym większy jest wpływ wdrożenia kryteriów ESG na wyniki zarządzania portfelem. Prowadzone badania na polskim rynku kapitałowym wykazują, że przeciętna stopa zwrotu osiągana przez fundusze deklarujące stosowanie strategii SRI nie różniła się istotnie od przeciętnej stopy zwrotu osiąganej przez fundusze stosujące klasyczne strategie inwestycyjne (zob. rozdz. 13. Tomasz Jedynak, Ocena efektywności strategii inwestycji spotecznie odpowiedzialnych na przyktadzie wyników polskich funduszy inwestycyjnych). Jednocześnie, uzyskane wyniki pozwalają przypuszczać, że fundusze SRI charakteryzują się niższym ryzykiem od funduszy klasycznych, ponieważ 
w przypadku zdecydowanej większości badanych funduszy SRI, wariancja ich stopy zwrotu była statystycznie różna od wariancji stopy zwrotu z przyjętego benchmarku. Ze względu na krótki horyzont czasowy badań oraz małą próbę badawczą, trudno wnioskować w szerszym zakresie, niemniej jednak uzyskane wstępne wyniki mogą sugerować, że stosowanie strategii społecznie odpowiedzialnych na rynku kapitałowym nie powoduje obniżenia efektywności i wzrostu ryzyka inwestycyjnego portfela.

W świetle sformułowanej przez Eugene'a Famę, fundamentalnej dla rynku kapitałowego hipotezy efektywności (Efficiency Market Hypothesis) (Fama 1970, s. 373-417; 1991, s. 1575-1617), rynek w sposób ciągły dyskontuje dostępne informacje w cenie notowanych papierów wartościowych. Zakres dostępnych inwestorom informacji oraz ich kompletność i rzetelność ma wpływ na poziom asymetrii informacyjnej na rynku kapitałowym. Biorąc pod uwagę, że profil ryzyko - dochód portfela inwestycji jest wypadkową czynników mierzalnych, stricte ekonomiczno-finansowych oraz pewnych parametrów pozafinansowych cechujących emitenta instrumentu finansowego, tj. np. informacji związanych z: ochroną środowiska, kontekstem społecznym i ładem korporacyjnym spółki (Environment, Social, Corporate Governan$c e-\mathrm{ESG})$, wynikami rozegranych meczów czy też informacji o transferach zawodników, inwestorzy podejmując decyzje, poszukują informacji dotyczących nie tylko parametrów ekonomicznych i finansowych spółki, lecz także podejmują się oceny ryzyka inwestycyjnego związanego z działalnością spółki w wymiarze pozafinansowym. Powstaje zatem pytanie dotyczące determinantów ceny papierów wartościowych i siły ich wpływu na dany walor. Jak wykazują badania, na rynku występują efekty działań emocjonalnych inwestorów giełdowych, które powodowane są pozaekonomicznymi czynnikami zewnętrznymi, tj.: wynik spotkania piłkarskiego czy dzień rozgrywania meczu w przypadku wyceny akcji spółek klubów sportowych (efekt „wygranych i przegranych meczów") (zob. rozdz. 10. Sebastian Majewski, Wplyw informacji nieekonomicznych na ksztattowanie się kursów akcji spótek prowadzacych działalność sportowa).

Dziękując autorom za trud przygotowania publikacji oraz recenzentom za cenne uwagi podnoszące wartość merytoryczną publikacji, mamy jednocześnie nadzieję, że będzie ona inspiracją do twórczej dyskusji naukowej oraz wsparciem dla praktyków w zakresie podejmowania decyzji na rynku kapitałowym.

Teresa Czerwińska Alojzy Z. Nowak 
16 Teresa Czerwińska, Alojzy Z. Nowak - Rynek kapitałowy w okresie dekoniunktury - wprowadzenie

\section{Bibliografia}

Demystifying Responsible Inwestment Performance (2007). A review of key academic and broker research on ESG factors. A joint report by The Asset Management Working Group. UNEP FI and Mercer, October.

Dyrektywa 2005/60 WE Parlamentu Europejskiego i Rady z dnia 26 października 2005 roku w sprawie przeciwdziałania korzystaniu z systemu finansowego w celu prania pieniędzy oraz finansowania terroryzmu (Dz. Urz. UE L309/15 (25.11.2005)).

European SRI Study (2010). Eurosif. Pobrano z: www.eurosif.

Fama, E.F. (1970). Efficient Capital Markets: A Review of Theory and Empirical Work, Journal of Finance, May, 373-417.

Fama, E.F. (1991). Efficient Capital Markets: II, Journal of Finance, 46(5), December 575-1617.

Kekäläinen, S. (2004). Sustainability of privately managed Pension Funds. Final thesis for the department of Organization and Strategy. University of Tilburg. Praca niepublikowana.

Ratajczak, M. (2012). Finansyzacji gospodarki, Ekonomista, 3.

Sopoćko, A. (2012). Gra finansowa - stagnacja czy wzrost bogatego świata?, Ekonomista, 4. 


$$
\text { CZĘŚĆ I }
$$

\section{TENDENCJE ROZWOJU RYNKU KAPITAŁOWEGO}





\title{
Rozdział I
}

\author{
DARIUSZ ZARZECKI*
}

\section{Zastosowanie koncepcji zarządzania wartością w największych spółkach notowanych na GPW w Warszawie}

\begin{abstract}
Streszczenie
W artykule omówiono istotę zarządzania wartością firmy oraz przedstawiono zalety i wady wynikające z wdrażania systemu VBM. Następnie zaprezentowano wyniki badań z 2013 r. dotyczące znajomości i zastosowania koncepcji zarządzania wartością w największych polskich spółkach giełdowych. Poruszono również kwestię wynagradzania zarządów w oparciu o wzrost wartości rynkowej kapitału własnego spółek i wskazano na kluczowe problemy związane z zarządzaniem opartym na wartości (VBM).
\end{abstract}

Słowa kluczowe: wycena przedsiębiorstw, zarządzanie wartością, spółki publiczne.

\section{Summary}

The paper presents an essence of the Value Base Management concept and discusses the key advantages and drawbacks of implementing the VBM system. Next, the key findings of a questionnaire review carried out in 2013 among the group of the biggest public companies in Poland have been presented. Linkage between value creation and remuneration of top managers has been examined. Finally, the major challenges facing implementation and application of the Value Based Management concept have been deliberated.

Keywords: business valuation, value-based management, public companies.

* Dr hab., prof. US Dariusz Zarzecki - Katedra Inwestycji i Wyceny Przedsiębiorstw, Instytut Zarządzania i Inwestycji, Uniwersytet Szczeciński; e-mail: dariusz.zarzecki@zarzecki.pl. 


\section{Istota zarządzania wartością (Value Based Management - VBM)}

Zarządzanie wartością jest podejściem w zarządzaniu kładącym nacisk na maksymalizację wartości dla akcjonariuszy (Rappaport 1999). Definicje podawane przez różnych autorów czy firmy doradcze są zbieżne (Cwynar i Cwynar 2002; Marcinkowska 2000; Jaki 2012; Borowiecki 2009, s. 96-105). Pewne różnice dotyczą określenia beneficjentów procesu maksymalizowania wartości (Jaki 2012). Większość autorów, firm doradczych i użytkowników wskazuje na właścicieli (akcjonariuszy, udziałowców) jako tych, którzy mają być najważniejszymi beneficjentami zarządzania wartością (Young i O’Byrne 2001). Niektórzy uważają, że chodzi o pomnażanie wartości z punktu widzenia wszystkich interesariuszy przedsiębiorstwa. To drugie podejście stosowane jest m.in. przez Deloitte\&Touche, Coca-Colę, AT\&T, Siemensa i Deutsche Bank (Cwynar i Cwynar 2002).

W rzeczywistości dwoistość podejścia jest pozorna: trudno wyobrazić sobie kreowanie wartości w spółce w długim okresie, ignorując bądź zaniedbując oczekiwania innych poza właścicielami interesariuszy. Zarząd niewykazujący troski o klientów prędzej czy później doprowadzi do destrukcji wartości dla właścicieli, spadnie bowiem sprzedaż. Niewłaściwe traktowanie pracowników, brak wyznaczonych ścieżek kariery, niemotywacyjne systemy wynagradzania, niskie płace, zła atmosfera, konflikty - to oczywiste przyczyny zwiększonej fluktuacji zatrudnienia i negatywnej selekcji, a w konsekwencji niższej wydajności i efektywności pracy, co również prowadzi do destrukcji wartości. Także relacje z dostawcami muszą spełniać przyjęte standardy (solidność kupiecka, dotrzymywanie terminów, elastyczność, długoterminowa wiarygodność etc.). W przeciwnym wypadku najlepsi (w sensie jakości dostarczanych surowców, podzespołów itd. oraz cen i innych warunków umowy) odmówią współpracy albo, postrzegając partnera jako bardziej ryzykownego, zaproponują współpracę na gorszych warunkach. Mechanizm jest w każdym przypadku podobny: zmniejsza się suma zdyskontowanych przepływów pieniężnych netto dla właścicieli, czyli wartość kapitału własnego, a więc bogactwo właścicieli. Powyższe nie oznacza, że problem optymalizacji działań nie istnieje. Odniesiemy się do tego w końcowej części niniejszego artykułu.

\section{Zalety i wady wynikające $z$ wdrażania systemu VBM}

Efektywne pomnażanie wartości przedsiębiorstwa, a tym samym skuteczna realizacja strategii kreowania wartości, wymaga kompleksowego podejścia poprzez stworzenie systemowej struktury zarządzania ukierunkowanego na 
pomnażanie wartości przedsiębiorstwa. Dlatego też kluczowe znaczenie dla efektywnego wdrażania strategii kreowania wartości ma system zarządzania wartością przedsiębiorstwa (system VBM). Negatywne dla przedsiębiorstwa i jego właścicieli konsekwencje występowania problemu agencji, wynikające z oddzielenia własności od zarządzania, sprawiają, że od systemu VBM oczekuje się $\mathrm{w}$ takiej sytuacji przede wszystkim nadania procesowi zarządzania przedsiębiorstwem cech zbliżonych do zarządzania właścicielskiego, przy którym właściciele przedsiębiorstwa za pomocą dostępnych instrumentów wywierają wpływ na jego funkcjonowanie oraz realizację zamierzonych celów. Implementacja takiego systemu ma zatem także w swoim założeniu za zadanie stworzenie warunków, w których menedżerowie myślą i działają, jak właściciele (Olsen 2002, za: Jaki 2011, s. 823).

Implementacja systemu VBM prowadzi w efekcie do istotnej redefinicji celów przedsiębiorstwa, przekształcenia jego struktury wewnętrznej, odnowienia procesów strategicznych i operacyjnych, a także wprowadzenia zmian w zakresie praktyk zarządzania zasobami ludzkimi. W rezultacie mamy tutaj do czynienia $\mathrm{z}$ wszechstronną i wielokierunkową zmianą w organizacji działalności przedsiębiorstwa (Starovic, Cooper i Davis 2004, s. 22, za: Jaki 2011, s. 825).

W literaturze wskazuje się na następujące zalety związane $\mathrm{z}$ wdrażaniem systemu VBM w przedsiębiorstwie (Jaki 2011, s. 827):

- wprowadzenie jednolitego, czytelnego języka w komunikacji wewnętrznej i zewnętrznej;

- narzędzie umożliwiające pełną porównywalność z alternatywnymi osiągnięciami;

- przydatność w procesie alokacji zasobów: lepsze rozróżnienie pomiędzy inwestycjami kreującymi i niekreującymi wartość;

- pozytywne oddziaływanie na wyniki finansowe, które uzyskiwane jest poprzez redukcje podstawy kapitałowej;

- skuteczne narzędzie strategiczne;

- użyteczne narzędzie orientowania zarządzania wokół nośników wartości;

- możliwość bardziej efektywnego kreowania wartości dla akcjonariuszy przez zwiększenie odpowiedzialności poszczególnych jednostek biznesowych.

Natomiast wśród wad związanych z wdrażaniem systemu VBM w przedsiębiorstwie szczególnie istotne są następujące:

- komplikacje wynikające $\mathrm{z}$ wielości form i metod zarządzania wartością;

- niezadowalająca użyteczność w przypadku niższych poziomów zarządzania z powodu trudności z prognozowaniem wartości; 
- konieczność poniesienia kosztów zarządzania związanych z wdrażaniem systemu;

- ograniczenia wynikające ze złożoności prowadzonego rachunku kreowania wartości;

- trudności z transformacją miar finansowych na operacyjne miary klientów;

- trudności techniczne i niejednoznaczność w pomiarze efektów, np. w odniesieniu do szacowania kosztu kapitału, szczególnie kosztu kapitału własnego.

\section{Badanie na temat zarządzania wartością w największych spółkach notowanych na GPW}

Wdrożenie zarządzania wartością, mapowania wartości i innych koncepcji tworzenia wartości niewątpliwie przyczyniło się do zwiększenia wagi i roli analityków ds. wyceny przedsiębiorstw i całej profesji wyceny przedsiębiorstw. Jednakże zastosowanie zarządzania wartością w mniej rozwiniętych krajach nie jest tak rozpowszechnione, jak w Stanach Zjednoczonych. Przykładowo w Polsce jedynie niewielka liczba spółek wdrożyła taki system. Badania ankietowe przeprowadzone wśród małych i średnich przedsiębiorstw w Południowych Morawach w Czechach pokazały, że tylko siedem przedsiębiorstw stosowało systemy wynagrodzeń oparte na wartości, z czego tylko jeden z nich opierał się na wskaźniku EVA (Jakubcova i Fedorova 2012).

W celu rozpoznania rzeczywistej znajomości koncepcji zarządzania przez wartość w polskich firmach, w okresie marzec-kwiecień 2013 r. przeprowadzono badanie ankietowe obejmujące grupę 50 największych, pod względem kapitalizacji, spółek notowanych na GPW w Warszawie. Chodzi przy tym wyłącznie o polskie spółki publiczne, a nie wszystkie największe spółki notowane na GPW, w tym zagraniczne (np. UniCredit, CEZ i MOL - spółki te zostały wyłączone z badania). Respondentom (członkom zarządu ds. finansowych lub ds. strategii/rozwoju) zadano osiem pytań, w tym cztery bezpośrednio, cztery zaś pośrednio związane ze znajomością i wykorzystaniem koncepcji $V B M$.

Odpowiedzi na pierwsze, podstawowe pytanie dotyczące znajomości koncepcji VBM (Czy zna Pan/Pani pojęcie zarzadzania przez wartość?) udzieliło 21 spółek, tj. 42,0\% z grupy pięćdziesięciu badanych podmiotów o największej wartości kapitału własnego. Siedemnastu przedstawicieli zarządów $(81,0 \%)$ udzieliło odpowiedzi twierdzącej, a czterech $(19,0 \%)$ 
negatywnej. Odsetek odpowiedzi negatywnych wydaje się być mimo wszystko wysoki. Jeżeli przyjmiemy, że szerokie upowszechnienie koncepcji VBM w skali światowej, w tym przede wszystkim w USA i Kanadzie, można wiązać z wydanymi na początku lat dziewięćdziesiątych dwiema fundamentalnymi pracami (Valuation: Measuring and Managing the Value of Companies T. Copelanda, T. Kollera i J. Murrina oraz The Quest for Value. A Guide for Senior Managers G.B. Stewarta III) ${ }^{1}$, to oznacza, że po upływie ćwierć wieku prawie $1 / 5$ zarządzających największymi spółkami publicznymi w Polsce nie zna wiodącej i bardzo popularnej w krajach rozwiniętych koncepcji zarządzania. Co więcej, od połowy lat dziewięćdziesiątych XX wieku dostępne są w Polsce prace naszych autorów (zarówno prace zwarte, jak i artykuły na temat VBM), a w 1997 r. wydawnictwo WIG Press wydało przetłumaczoną na język polski pierwszą z wymienionych wcześniej książek (Wycena: mierzenie i ksztaltowanie wartości firm). Dwa lata później ukazała się w Polsce, nakładem WIG Press, praca A. Rappaporta pt. Wartość dla akcjonariuszy. Poradnik menedżera $i$ inwestora. W ostatnich dwudziestu latach w programach studiów czołowych wydziałów ekonomicznych w Polsce można znaleźć liczne odniesienia do koncepcji VBM (całe przedmioty, elementy przedmiotów, a nawet specjalności i dedykowane zarządzaniu wartością studia podyplomowe, szkolenia i konferencje). Tak znaczny odsetek zarządzających, którzy nie znają istoty i podstawowych założeń koncepcji VBM może więc niepokoić. Tym bardziej, że badania dotyczyły wyłącznie największych spółek. Z dużym prawdopodobieństwem można przyjąć, że poza grupą dużych firm, znajomość koncepcji VBM wśród kadry zarządzającej polskich spółek jest jeszcze mniejsza, a w odniesieniu do podmiotów nienotowanych, których jest zdecydowanie najwięcej, wiedza o VBM jest zapewne najsłabsza.

Sama znajomość koncepcji VBM nie przesądza jeszcze, iż jest ona stosowana w praktyce. Potwierdza to rozkład odpowiedzi na drugie pytanie (Czy firma, którą Pan/Pani reprezentuje wykorzystuje Value Based Management (VBM) w zarządzaniu firma?). Tylko dziesięciu spośród siedemnastu zarządzających znających koncepcję VBM $(58,8 \%)$ potwierdziło jej stosowanie w zarządzanych przez siebie spółkach. Oznacza to, że 47,6\% spółek, których przedstawiciele udzielili odpowiedzi, wykorzystuje VBM w zarządzaniu firmą. Wdrożenia systemu VBM miały miejsce stosunkowo niedawno, ponieważ spośród tych, którzy udzielili odpowiedzi na to pytanie jako rok rozpoczęcia stosowania koncepcji VBM wskazano wyłącznie lata po 2000 roku

1 W kolejnych latach ukazały się liczne prace innych autorów, np.: Young i O’Byrne (2001); Ehrbar (1998); Knight (1998). 
(konkretnie: 2003, 2009 i 2012). W pozostałych siedmiu przypadkach nie podano roku wdrożenia systemu VBM.

Aż 10 respondentów deklaruje wolę stosowania systemu VBM w przyszłości, co stanowi 76,9\% wszystkich odpowiedzi udzielonych na to pytanie. Można to interpretować w ten sposób, że firmy wykorzystujące VBM zamierzają robić to również w przyszłości, a poza tym aż 5 spośród pozostałych (nie stosujących VBM) spółek planuje wdrożyć i stosować VBM.

Zdecydowanie pozytywnie należy ocenić $100 \%$ pozytywnych odpowiedzi na pytanie dotyczące wykorzystywania w ocenie projektów inwestycyjnych w swoich firmach kryterium wartości bieżącej netto NPV lub wewnętrznej stopy zwrotu IRR. Wszyscy respondenci potwierdzili, że zawsze wykorzystują przynajmniej jedno $\mathrm{z}$ tych kryteriów. W porównaniu z wcześniejszymi i szerszymi pod względem zakresu i wielkości próby badaniami, wyniki te są bardzo dobre. W badaniach przeprowadzonych w 1994 roku na próbie 114 podmiotów z województwa zachodniopomorskiego zaledwie $23 \%$ respondentów wskazało na NPV, a tylko $8 \%$ na IRR jako stosowane przez nich w praktyce kryteria ${ }^{2}$. Natomiast w badaniu z 2005 roku wśród 239 odpowiedzi było $39 \%$ potwierdzających wykorzystywanie NPV i odpowiednio 38\% IRR (Rogowski 2013, s. 436). Postęp jest więc wyraźny i spektakularny i nie zmienia tego różna wielkość i struktura próby oraz nieco odmienny sposób sformułowania pytań.

Przeprowadzone badanie dotyczące wiedzy nt. VBM, jej zastosowań w praktyce oraz planów wdrożenia wskazuje, że w grupie największych polskich spólek publicznych prowartościowy paradygmat zarządzania jest rzeczywistością. Nie jest to tylko postulat teorii wobec praktyki, aczkolwiek deklaracje o stosowaniu koncepcji VBM wymagałyby bardziej pogłębionej weryfikacji - najlepiej w formie konkretnych studiów przypadku.

Zwolennicy teorii VBM zwykle nie poświęcają w ogóle lub bardzo niewiele miejsca krytyce koncepcji zarządzania przez wartość i różnym pułapkom związanym z jej praktycznym zastosowaniem. Pojawiają się poglądy, że jest to zgrabnie opakowany w spójną teorię i prezentujący się atrakcyjnie dla zarządzających produkt firm doradczych. Krytycznie o koncepcji VBM wypowiadali się m.in. Grinblatt, Titman, Damodaran. Bardzo ciekawy krytyczny wywód nt. koncepcji VBM zaprezentował S. Kasiewicz w dostępnym również w Internecie artykule pt. Koncepcja zarzadzania wartościa jako źródto kryzysu finansowego (2009).

2 Warto podkreślić, że były to spółki w większości małe i średnie. Zob. Zarzecki (1997). 


\section{Wynagradzanie przez wartość}

Sformalizowane systemy zarządzania wartością wiążą się ściśle z systemami motywacyjnymi, które uzależniają zmienną część wynagrodzenia menedżerów od wyników, a szczególnie od wzrostu rynkowej wartości kapitału własnego. Aż 12 z 13 respondentów, tj. 92,3\%, którzy udzielili odpowiedzi na to pytanie, potwierdziło występowanie motywacyjnego systemu wynagradzania członków zarządu. W systemie dominują zdecydowanie nagrody pieniężne występujące w 11 spośród 12 największych podmiotów giełdowych, które udzieliły odpowiedzi na to pytanie i równocześnie posiadają motywacyjny system wynagradzania. W czterech przypadkach $(33,3 \%)$ stosowane są opcje na akcje. Również w czterech firmach $(33,3 \%)$ menedżerowie wynagradzani są w formie obligacji zamiennych na akcje, przy czym w dwóch przypadkach $(16,7 \%)$ stosowane są zarówno opcje na akcje, jak i obligacje zamienne. W dwóch firmach $(16,7 \%)$ menedżerowie mogą otrzymać wynagrodzenie w postaci akcji. W jednej spółce system wynagradzania daje zarządzającym możliwość wykupu menedżerskiego spółki (Management Buy-Out).

Aż $41,7 \%$ respondentów twierdzi, że w ich firmach zmienne elementy wynagrodzenia stanowią więcej niż $40 \%$. Ale w $1 / 3$ spółek udział ten jest mniejszy niż 20\%. Średnio zmienna część wynagrodzenia menedżerów w badanej próbie wyniosła około $35 \%$. Identyczny udział części zmiennej wynagrodzenia uzyskano w badaniach przeprowadzonych na polskim rynku przez $\mathrm{PwC}$ w 2012 r. (Wynagrodzenie największych spótek giełdowych... 2013). Udział ten (35\%) jest więc nieco wyższy niż wskazują dane dotyczące wszystkich spółek notowanych na GPW w Warszawie (30\% - średnią obniżają mniejsze spółki, w których zmienna część wynagrodzenia jest niższa niż w spółkach największych). Udział zmiennych składników wynagrodzenia wynoszący średnio 30\% jest na GPW zdecydowanie niższy niż w przypadku spółek amerykańskich, gdzie udział ten w pakiecie wynagrodzeniowym menedżerów najwyższego szczebla (członków zarządu) oscyluje średnio wokół 70\% (w Wielkiej Brytanii odsetek ten jest nieznacznie mniejszy). W Polsce aż 2/3 uposażeń kluczowych menedżerów nie zależy więc bezpośrednio od wyników działalności, będąc stałą częścią wynagrodzenia. Pomiędzy standardami polskimi a anglosaskimi jest więc w tym zakresie ogromna różnica.

$\mathrm{Z}$ jednej strony charakterystyczne dla Polski proporcje podziału całkowitej płacy na część stałą i zmienną mogą budzić niepokój. Stosunkowo niewielki udział ruchomej części wynagrodzenia oznacza słabszą zależność łącznej gratyfikacji od wyników i mniejszą motywację do ich poprawiania. 
Z drugiej zaś - to także mniejsza skłonność do ryzyka - szczególnie opartego na agresywnym korzystaniu $\mathrm{z}$ długu.

Wspomniane badania PwC wskazują, że w latach 2011-2012 zainteresowanie długookresowymi programami motywacyjnymi (Long-Term Incentive Plan - LTIP) w największych polskich spółkach giełdowych kształtowało się na podobnym poziomie (około $40 \%$ spółek oferowało swoim top menedżerom takie motywatory). Mimo że udział ten jest znacznie wyższy niż jeszcze kilka lat wcześniej (około 30\%), to nadal odbiega od średnich obserwowanych na rozwiniętych rynkach kapitałowych, gdzie udział ten jest dużo większy i sięga niemal $100 \%$.

Do rewizji myślenia na temat struktury wynagradzania członków zarządu skłonił kryzys z lat 2007-2008. Uznano, że w pogoni za coraz wyższymi nagrodami i innymi korzyściami oferowanymi w ramach agresywnych pakietów wynagrodzeniowych (np. tymi, które wynikają ze wzrostu wartości akcji zarządzanej spółki), menedżerowie zbyt często zapominają o ryzyku i hamulcach bezpieczeństwa, decydując się na realizację projektów obiecujących co prawda wysokie stopy zwrotu (a zatem także atrakcyjne bonusy), ale także nieproporcjonalnie wysokie ryzyko. $\mathrm{W}$ rezultacie powszechne do niedawna przekonanie, że im większy udział części zmiennej w całkowitym wynagrodzeniu, tym lepiej, w krótkim czasie ustąpiło miejsca poglądom znacznie bardziej konserwatywnym. Widać to wyraźnie m.in. w zaleceniach licznych instytucji, w tym tych związanych z Unią Europejską. Do tej pory nikt nie pokusił się jednak o wskazanie rozsądnej struktury wynagrodzenia członków zarządów i nie zaproponował przekonującej i naukowo uzasadnionej metody optymalizacji w tej dziedzinie.

Jak zauważa A. Cwynar (2012), ,problem jest dużo bardziej złożony i bez wątpienia wykracza poza ramy dyskusji na temat tego, jaki procent w całkowitym wynagrodzeniu powinny stanowić bodźce zależne od wyników, a jaki stała płaca. Dotyczy on między innymi kwestii wyboru samego miernika wyników. Być może jest tak, że duży udział składnika ruchomego nie w każdym przypadku musi prowokować menedżerów do podejmowania się realizacji najbardziej ryzykownych projektów. Wielu wierzy, że można temu przeciwdziałać za pomocą konstrukcji właściwego miernika bądź mierników menedżerskich osiągnięć. Tymczasem płacenie za wyniki musi brać pod uwagę, że na menedżerskie premie mógł zapracować wyłącznie rynek (branża, cała gospodarka albo jedno i drugie jednocześnie). Dziś nikt nie ma też złudzeń co do tego czy istnieje miernik, którym nie dałoby się manipulować. W związku z tym, że płacenie za wyniki oznacza konieczność posługiwania się miernikami tych wyników, musi ono brać też pod uwagę, że za mene- 
dżerskimi premiami kryje się menedżerska inżynieria będąca rezultatem ich wiedzy na temat właściwości używanego do oceny ich wyników miernika".

Badania, do których odwołuje się A. Cwynar pokazują, że większość akcjonariuszy byłaby skłonna zaakceptować jeszcze większe niż obecnie wynagrodzenia menedżerów, ale pod warunkiem, że płacenie za wyniki nie byłoby drogą prowadzącą tylko $\mathrm{w}$ jedną stronę - wyższych wynagrodzeń za lepsze rezultaty. Chodzi o bardziej symetryczny układ co do ekspozycji na ryzyko niepomyślnego rozwoju wydarzeń (downside risk). Wiadomo, że inwestorzy je ponoszą: mogą stracić część zainwestowanego kapitału. Strata menedżera w takim przypadku to brak premii albo bezwartościowe opcje zakupu akcji. Dyskusja na temat menedżerskich wynagrodzeń musi brać pod uwagę przestrzenną dychotomię w skali świata. Stany Zjednoczone istotnie różnią się pod tym względem od pozostałych gospodarek. Różnice dotyczą przede wszystkim dwóch - tak naprawdę kluczowych - spraw: wielkości i struktury menedżerskiego wynagrodzenia. CEO amerykańskich spółek zarabiają przeciętnie więcej niż prezesi spółek mających siedziby w jakimkolwiek innym kraju. Większą niż gdziekolwiek indziej część całkowitego wynagrodzenia stanowi też u nich składnik ruchomy (zmienny), zależny od wyników działalności. Należy przy tym zwrócić uwagę, że zmienny komponent płacy tworzą tam przede wszystkim instrumenty związane z kapitałem akcyjnym/akcjami zarządzanej przez menedżera spółki (equity-based compensation) - opcje zakupu akcji (stock options), akcje warunkowe (restricted stock), prawo do udziału w zyskach kapitałowych (stock appreciation rights) i podobne (Cwynar 2012).

$\mathrm{W}$ żadnym innym kraju wynagradzanie związane $\mathrm{z}$ akcjami (chodzi nie tylko o samo wynagradzanie akcjami), jak podkreśla A. Cwynar, nie stało się tak powszechne jak w Stanach Zjednoczonych. Z raportów płacowych takich firm, jak Towers Perrin, Mercer czy Hay Group wynika, że wartość całkowitego pakietu płacowego przeciętnego CEO w Stanach Zjednoczonych może być nawet dwukrotnie wyższa niż np. w Niemczech, natomiast polscy menedżerowie zarabiają nawet trzykrotnie mniej niż niemieccy czy brytyjscy. Wynagrodzenie zmienne CEO amerykańskiej spółki stanowi średnio ok. $60-70 \%$ całego pakietu płacowego - tyle, ile przeciętnie stała płaca zasadnicza prezesa polskiej spółki (top menedżerowie w krajach, takich jak Niemcy czy Wielka Brytania są pomiędzy tymi dwoma skrajnymi charakterystykami; w krajach anglosaskich udział części zmiennej jest - przeciętnie - wyższy). W okresie szczytowej popularności menedżerskich opcji zakupu akcji (2001 r.) ich udział w całkowitej wartości menedżerskiej płacy sięgnął w Stanach Zjednoczonych prawie 55\%, podczas gdy w Europie Zachodniej było to średnio zaledwie kilkanaście procent (w Azji i Ameryce Południo- 
wej nieco ponad 20\%). Wniosek jest taki, że Amerykanie zarabiają więcej, ponieważ mogą - na większe niż gdziekolwiek indziej zarobki pozwala im relatywnie duża ruchoma część płacy. Jednocześnie dominacja Stanów Zjednoczonych w dziedzinie wysokości menedżerskich wynagrodzeń sprawia, że to właśnie tam debata na ich temat jest najbardziej gorąca, a w rezultacie jak wielokrotnie wcześniej - to często stamtąd rozpoczyna się dyfuzja na cały świat nowych rozwiązań będących reakcją na budzący kontrowersje obecny stan rzeczy w dziedzinie menedżerskich wynagrodzeń (Cwynar 2012).

Konkretyzacją tych postulatów na niwie krajowej są zaproponowane przez MSP w kwietniu 2013 r. tzw. dobre praktyki w zakresie kształtowania wysokości i składników wynagrodzeń, w przypadku zawierania kontraktów menedżerskich z członkami zarządów wybranych spółek z udziałem Skarbu Państwa. Zgodnie z tymi wytycznymi, którymi będą mogły kierować się rady nadzorcze, wysokość kontraktu nie powinna odbiegać od średnich wynagrodzeń na rynku oraz składać się z części stałej (60\%) i zmiennej (40\%) (MSP chce, by wynagrodzenia... 2013).

Problem rzeczywiście wydaje się być znacznie głębszy i ma prawdopodobnie charakter strukturalny. Duża ranga zmiennej części wynagrodzenia w łącznych dochodach top menedżerów ma sens, jeśli otoczenie jest stabilne i wyniki rzeczywiście da się przypisać talentom, pracowitości i sprawności decydentów. Tymczasem współczesne otoczenie jest globalne i bardzo turbulentne, co powoduje, że wyniki firmy są często słabo lub zupełnie niezwiązane z efektami pracy menedżerów. Paradoksalnie, może być więc tak, że potwierdzony cytowanymi wcześniej badaniami relatywnie niski udział zmiennej części wynagrodzeń w największych polskich spółkach giełdowych jest raczej zaletą niż wadą ${ }^{3}$. Przy dużej zmienności otoczenia i obiektywnych trudnościach w przypisaniu przyrostu wartości akcji do działań menedżerów niższy udział części zmiennej jest mniej ryzykowny dla spółki i jej akcjonariuszy. Jeśli jednak zmienna część wynagrodzenia miałaby mieć większe znaczenie, to rekomendowanym rozwiązaniem jest wdrażanie systemów wynagradzania z premiami i nagrodami uznaniowymi, przyznawanymi przez rady nadzorcze po kompleksowej ocenie wyników spółki, sytuacji sektora i gospodarki, zdarzeń nadzwyczajnych (np. gwałtownych zmian cen czy kursów walut). Jest to zdecydowanie lepsze rozwiązanie niż tworzenie regulaminów premiowania i nagradzania zawierających algorytmy, które mogą

3 Problem braku właściwych relacji pomiędzy wynikami spółek a wynagrodzeniami czołowych menedżerów był w polskiej literaturze obecny już od dawna. Zob. np. Mączyńska i Zawadzki (1999). 
skłaniać zarządzających do podejmowania niewłaściwych, a niekiedy wręcz patologicznych i skrajnie ryzykownych działań i decyzji.

\section{Próba podsumowania i potrzeba dalszych poszukiwań nowego paradygmatu}

W literaturze przedmiotu w licznych pracach zarządzanie wartością jest nadal przedstawiane jako wiodący nurt współczesnych nauk o zarządzaniu. Kluczowym problemem i wadą tej koncepcji jest to, co miało być jej zaletą: oparcie systemu na wycenie rynkowej. Zmienność rynków akcji będąca pochodną przynależnego tym rynkom wysokiego ryzyka, tudzież spekulacyjny przepływ kapitału w skali globalnej, a nawet celowe działania na rozchwianie rynków finansowych, powodują, że wycenę rynkową trudno uznać za obiektywny miernik wyników zarządu spółki. Stochastycznie biorąc, taki związek nie jest wcale oczywisty, co potwierdzają m.in. wyniki badań prowadzonych przez M. Lynch oraz M.A. Khana, N.H. Shaha i A. ur Rehmana (z badań M. Lynch przeprowadzonych już 1997 r. wynika, że ta korelacja jest ledwie śladowa; najnowsze badania zrealizowane na pakistańskim rynku kapitałowym wykazały ujemną korelację pomiędzy EVA a stopą zwrotu z akcji) (Khan, Shah i ur Rehman 2012). Nie ulega wątpliwości, że w krótkich okresach zmienność cen akcji jest funkcją tak wielu czynników, że trudno tutaj o szukanie sensownych związków z efektami pracy zarządu. Jest to możliwe w średnim i długim okresie, aczkolwiek nawet w dłuższym horyzoncie czasowym mamy obiektywne i często silnie oddziałujące czynniki zakłócające. Przykładowo, o zmianie cen akcji na przestrzeni kilku lat decydują m.in. perspektywy sektora, w którym działa spółka. Jest to w większości przypadków czynnik niezależny od decyzji i sprawności zarządu.

Innym problemem, już na poziomie operacjonalizacji systemu zarządzania wartością, jest jego skomplikowanie i zbiurokratyzowanie oraz mnóstwo szczegółowych kwestii metodycznych, organizacyjnych i realizacyjnych (Pietrewicz 2008, s. 83-88). W artykule L. Pietrewicza poddano ocenie praktykę zarządzania wartością (VBM). Analizowano dwa obszary potencjalnych słabości VBM: obszar wdrożeń i efekty funkcjonowania VBM w firmie. Wyniki pokazują szereg słabości tej koncepcji Do najważniejszych problemów w obszarze wdrażania zaliczono niemożność obiektywnego określenia najlepszej miary wartości i techniczne trudności implementacji miar (związane np. z określeniem kosztu kapitału i wysokości zaangażowanego kapitału), zwłaszcza na poziomie wydziałów. W obszarze efektów stosowania VBM 
główne słabości to krótkowzroczność i orientacja na efektywność kosztem kreatywności, prowadzące do pogorszenia efektywności w długim okresie.

I kolejna fundamentalna wada: nie znając przyszłości, z definicji nie jesteśmy w stanie optymalizować naszych decyzji na podstawie kryterium maksymalizacji wartości bieżącej przepływów pieniężnych netto. Znamy jedynie oczekiwaną rentowność aktualnie rozpatrywanych projektów (które też są obarczone ryzykiem), ale nie wiemy kiedy i jakie okazje inwestycyjne pojawią się w przyszłości.

Kryzys globalny wywołał eksplozję dyskusji na temat dysfunkcji sektora finansowego. Problematyka te jest przedmiotem licznych publikacji, w których wskazuje się, że liberalizacja przepisów, finansowe innowacje, zniesienie kontroli kapitału i globalizacja systemu finansowego sprawiają, że sektor ten rozrósł się do ogromnych, nieuzasadnionych rozmiarów. Ostrzeżenia na ten temat formułowane były także wcześniej (Mączyńska 2011). Już w 1936 r. John M. Keynes niemalże proroczo oceniał, że „W miarę ulepszania organizacji rynków pojawia się istotne niebezpieczeństwo, że spekulacja weźmie górę nad przedsiębiorczością. Spekulanci mogą być nieszkodliwi, gdy są niczym piana na spokojnych wodach przedsiębiorczości. Ale sytuacja staje się poważna, gdy przedsiębiorczość poczyna być pianą na wirze spekulacji” (Keynes 2003, s. 140, za: Mączyńska 2011). Ten kierunek przemian sprawia, że, stuga staje się panem (Mączyńska 2011). S. Kasiewicz zwraca uwagę na istotne słabości koncepcji zarządzania wartością i wymienia trzy główne uwarunkowania, które jego zdaniem przyczyniły się do kryzysu finansowego z 2008 r. (Kasiewicz 2009):

- wpływ procesów postępującej globalizacji, implikujących wielokierunkowe zmiany w zakresie funkcjonowania i rozwoju rynków oraz działających na nich podmiotów;

- agresywność systemów motywacyjnych stanowiących kluczowy składnik systemu zarządzania wartością;

- brak integracji pomiędzy koncepcją zarządzania wartością a koncepcją zarządzania ryzykiem $\mathrm{w}$ przedsiębiorstwie.

Koncepcja zarządzania wartością jest stosunkowo nowa, wywarła jednak znaczący wpływ na zmianę paradygmatu zarządzania i rozwój współczesnych przedsiębiorstw - szczególnie dużych korporacji międzynarodowych, amerykańskich i z innych krajów rozwiniętych. Koncepcja ta ma również swoje wady, ograniczenia i pułapki. Teza, że niewłaściwe zastosowanie VBM było jedną z przyczyn problemów finansowych, które dotknęły liczne firmy zachodnie (np. Enron, Worldcom, Parmalat) wydaje się być prawdziwa. 
Menedżerowie podejmowali ogromne ryzyko kosztem właścicieli (hazard moralny), a wobec przytłaczających ich spółki problemów uciekali się często do manipulacji księgowych.

Nie ulega wątpliwości, że dyskusja na temat możliwości zastosowania i przydatności zarządzania wartością i różnych mierników związanych z tworzeniem wartości, będzie kontynuowana w świetle nadal obowiązującego prowartościowego paradygmatu nauk o zarządzaniu i równocześnie nasilającej się krytyki i kontestowania jego podstawowych elementów (Jaki 2012).

\section{Bibliografia}

Borowiecki, R. (red.) (2009). Pomiar i ocena procesów kreowania wartości w badaniu efektywności przedsiębiorstwa. Kraków: Wydawnictwo Fundacja Uniwersytetu Ekonomicznego w Krakowie.

Copeland, T., Koller, T. i Murrin, J. (1990). Valuation: Measuring and Managing the Value of Companies. New York: John Wiley \& Sons.

Cwynar, A. (2012). Wynagrodzenia menedżerów: fakty i mity. Pobrano z: http://biznes.pl/ magazyny/manager/statystyka/wynagrodzenia-menedzerow-fakty-i-mity,5113925,magazyn -detal.html.

Cwynar, A. i Cwynar, W. (2002). Zarzqdzanie wartościq spótki kapitałowej. Koncepcje, systemy, narzędzia. Warszawa: Fundacja Rozwoju Rachunkowości w Polsce.

Eccles, R.G., Herz, R.H., Keegan, E.M. i Phillips, D.M.H. (2001). The Value Reporting Revolution. New York: Wiley \& Sons.

Ehrbar, A. (1998). EVA: The Real Key to Creating Wealth. New York: Wiley \& Sons.

Jaki, A. (2011). System zarządzania wartością przedsiębiorstwa. W: D. Zarzecki (red.), Zarzadzanie finansami. Inwestycje, wycena przedsiębiorstw, zarzadzanie wartościa, Zeszyty Naukowe Uniwersytetu Szczecińskiego Nr 639.

Jaki, A. (2012). Mechanizmy procesu zarządzania wartościa przedsiębiorstwa. Kraków: Wydawnictwo Uniwersytetu Ekonomicznego w Krakowie.

Jakubcova, M. i Fedorova, A. (2012). Implementation of EVA indicator in value based remuneration system in small and medium-sized enterprises, Acta univ. agric. et silvic. Mendel. Brun., LX, No. 4. Pobrano z: www.mendelu.cz/dok_server/slozka.pl?id=57208; download $=97648$.

Kasiewicz, S. (2009). Koncepcja zarządzania wartością jako źródło kryzysu finansowego, Finansowanie Nieruchomości, 20.

Keynes, J.M. (2003). Ogólna teoria zatrudnienia, procentu i pieniądza, przekład M. Kalecki, S. Rączkowski. Warszawa: Wydawnictwo Naukowe PWN.

Khan, M.A., Shah, N.H. i ur Rehman, A. (2012). The Relationship between Stock Return and Economic Value Added (EVA): A Review of KSE-100 Index, January 26. Pobrano z: http://papers.ssrn.com/sol3/papers.cfm?abstract_id=1992209.

Kimmel, G.S. (1984). Creating Shareholder Value: A Primary Financial Objective, Forum, June.

Knight, A. (1998). Value Based Management. Developing a Systematic Approach to Creating Shareholder Value. New York: McGraw-Hill. 
Mączyńska, E. (2011). Gdy sługa staje się panem, czyli dysfunkcje pomiaru wartości biznesu i wyników działalności gospodarczej. W: D. Zarzecki (red.), Czas na pieniądz. Zarzadzanie finansami. Inwestycje, wycena przedsiębiorstw, zarzq̨dzanie wartościa, Szczecin: Wydawnictwo Naukowe Uniwersytetu Szczecińskiego.

Mączyńska, E. i Zawadzki, M. (1999). Wartość przedsiębiorstwa a wynagrodzenia menedżerów, Nasz Rynek Kapitatowy, 10.

Marcinkowska, M. (2000). Kształtowanie wartości firmy. Warszawa: Wydawnictwo Naukowe PWN.

MSP chce, by wynagrodzenia menedżerów $w$ części zależaty od wyników $i$ realizacji inwestycji (2013). Pobrano z: http://finanse.wp.pl/kat,7069,title,MSP-chce-by-wynagrodzeniamenedzerow-w-czesci-zalezaly-od-wynikow-i-realizacji-inwestycji,wid,15464335,wiadomo sc.html?ticaid $=110 \mathrm{ff} 8$.

Myers, R. (1996). Metric Wars, CFO: The Magazine for Senior Financial Executives, October.

Olsen, E. (2002). New Directions in Value Management, The Boston Consulting Group, Inc. 2002. Pobrano z: http://www.bcg.com/impact_expertise/publications/files/New_Directions_ Value_Management_Dec2002.pdf.

Pietrewicz, L. (2008). Pułapki zarządzania wartością, Ekonomika i Organizacja Przedsiębiorstwa, 2.

Porter, M. (1985). Competitive Advantage: Creating and Sustaining Superior Performance. New York: Free Press.

Rappaport, A. (1986). Creating Shareholder Value. The New Standard for Business Performance. New York: The Free Press.

Rappaport, A. (1999). Wartość dla akcjonariuszy. Poradnik menedżera i inwestora. Warszawa: WIG Press.

Reimann, B.C. (1986). Implementing Value-Based Strategic Management, Planning Review, July.

Rogowski, W. (2013). Rachunek efektywności inwestycji. Wyzwania teorii i potrzeby praktyki. Warszawa: Oficyna Wolters Kluwer Polska.

Starovic, D., Cooper, S. i Davis, M. (2004). Maximising Shareholder Value. Achieving clarity in decision- making. London: CIMA.

Stewart, G.B., III (1991). The Quest for Value. A Guide for Senior Managers. Harper-Business.

Treynor, J.T. (1981). The Financial Objective in the Widely Held Corporation, Financial Analysts Journal, March-April.

www.bcg.com/impact_expertise/publications/files/New_Directions_Value_Management_Dec 2002.pdf.

www.rf.edu.pl/uploads/media/S_Kasiewicz_02.pdf.

Wynagrodzenia największych spótek gietdōwych w 2012 roku. Czy giełda poptaca? (2013). Warszawa, 12 czerwca. Pobrano z: http://www.pwc.pl/pl/biuro-prasowe/assets/pwc_prezentacja_wynagrodzenia_czlonkow_zarzadu.pdf.

Young, S.D. i O'Byrne, S.F. (2001). EVA and Value Based Management. A Practical Guide to Implementation. New York: McGraw-Hill.

Zarzecki, D. (1997). Metody oceny efektywności inwestycji - wybrane zagadnienia. Szczecin: Interbook.

Zarzecki, D. (2006). Zastosowanie ekonomicznej wartości dodanej w wycenie przedsiębiorstw. W: Strategie wzrostu wartości przedsiębiorstw. Teoria i praktyka, Zeszyty Naukowe Uniwersytetu Szczecińskiego, nr 434, Prace Instytutu Ekonomiki i Organizacji Przedsiębiorstw, nr 48, Szczecin. 


\title{
Rozdział II
}

\author{
KATARZYNA WŁODARCZYK*
}

\section{Pozytywistyczny paradygmat wartości}

\begin{abstract}
Streszczenie
Patrząc przez pryzmat pozytywistycznych założeń oraz kuhnowskiej teorii rozwoju nauki, można utożsamić wartość fundamentalną, wynikającą z modelu DCF, z pozytywistycznym paradygmatem wartości. Jednakże pewne zdarzenia zachodzące na rynkach finansowych można interpretować jako odchylenia od istniejącego paradygmatu. Wynika to z faktu, że powszechnie akceptowalny model wyceny przedsiębiorstw zdyskontowanymi przepływami pieniężnymi nie jest jedynym źródłem determinującym pojmowanie wartości przez inwestorów giełdowych. Autor uważa, że występuje wiele determinantów, które wpływają na pojmowanie wartości przedsiębiorstw przez inwestorów, lecz nie można dokładnie zmierzyć siły ich oddziaływania na pojmowaną wartość inwestorów. Wiąże się to z faktem, iż determinanty te dotyczą subiektywnej kategorii wartości, wpływu finansów behawioralnych oraz informacji i jej wagi dla każdego z inwestujących.
\end{abstract}

Słowa kluczowe: paradygmat, pozytywizm, Kuhn, wartość fundamentalna, model DCF.

\begin{abstract}
In the light of Kuhn's theory of science and positivist assumptions, we can identify the fundamental value resulting from the DCF model as an example of the positivist paradigm values. However, certain events appearing in the financial markets, can be interpreted as aberrations from the existing paradigm. This is due to the fact that the generally acceptable valuation model of business discounted by cash flows is not the only source of determining the stock market investors' understanding of value. The author believes that there are many determinants that influence the investors' perception of the value, but the force of their impact value cannot be accurately measured. This stems from the fact that the aforementioned determinants are linked with the category of subjective values, the impact of both behavioural finance and information and to the significance of the information for each of the investors.
\end{abstract}

Keywords: paradigm, positivism, Kuhn, fundamental value, DCF model.

\footnotetext{
Mgr Katarzyna Włodarczyk - Zakład Zarządzania Finansami, Instytut Organizacji i Zarządzania, Wydział Informatyki i Zarządzania, Politechnika Wrocławska; e-mail: katarzyna.wlodarczyk@pwr.wroc.pl.
} 


\section{Wstęp}

Słowo „wartość” pochodzi od słowa łacińskiego valor lub valere - które oznacza wartość, być wartym oraz od greckiego aksios, co znaczy odpowiedni, wart, godny, cenny. Ze względu na szeroki zakres występowania słowa „wartość” różne są jego definicje. Problem w zdefiniowaniu pojęcia „wartość" bardzo trafnie obrazują słowa polskiego filozofa Władysława Tatarkiewicza: „Zdefiniowanie wartości jest trudne, jeśli w ogóle możliwe [...]. To, co wygląda na definicję wartości, jest raczej zastąpieniem wyrazu przez inny wyraz mniej więcej to samo znaczący albo jest jego omówieniem" (1978, s. 61). Mimo braku jednorodnej i uznanej przez wszystkich definicji, warunkiem obligatoryjnym przy ustaleniu wartości jest określenie przedmiotu wartościowania.

Mówiąc o wartości przedsiębiorstwa, używa się pojęcia „wartość fundamentalna” lub „wartość wewnętrzna przedsiębiorstwa”, które określa zdolność firmy do osiągania dochodów. Może być na przykład rezultatem wyceny przedsiębiorstwa za pomocą powszechnie używanego modelu dyskontującego przyszłe przepływy pieniężne (discounted cash flow - DCF). Model ten szacuje wartość bieżącą przyszłych oczekiwanych przepływów pieniężnych, bazując na koncepcji wartości pieniądza w czasie. Koncepcja ta pojawiała się już w XIX wielu w literaturze aktuarialnej, lecz historia wprowadzenia jej do wyceny przedsiębiorstw, jako oceny efektywności inwestycji, jest stosunkowo krótka, sięga bowiem dopiero od lat pięćdziesiątych XX wieku (Zarzecki 1999), w przeciwieństwie do samej metody dyskontowania przepływów pieniężnych, której początki odnotowano już w starożytności (Parker 1968). Duży wkład w rozwój tej metody miała praca Fishera, który w książce The Theory of Interest omówił wybór wariantów inwestycyjnych, maksymalizując wartość bieżącą (Parker 1968). Prekursorami teorii DCF dotyczącej wyceny przedsiębiorstw w literaturze przedmiotu nazywa się H.M. Millera i F.M. Modiglianiego, natomiast w praktycznym zastosowaniu - J.M. Sterna (Zarzecki 1999).

Założenia i technika tego modelu wyceny powodują, że ma on pozytywistyczne ujęcie. Wynika to z tego, że w procesie wyceny świat jest obiektywny i niezależny od podmiotu poznającego go, czyli analityka. Dzięki regularnym obserwacjom badacza, poprawnym modelom naukowym i bezstronnej postawie samego analityka można odkrywać przyczynowość oraz tłumaczyć, prognozować i monitorować zjawiska, zdarzenia. Dzięki odrębności podmiotu badania i subiektywności człowieka istnieją obiektywne fakty, nienacechowane czynnikami wartościującymi badacza. Zatem wiedza jest autentyczna, 
ponieważ jej źródłem jest mierzalna obserwacja, która dostarcza tych samych konkluzji rozmaitym inwestorom zajmującym się tymi samymi podmiotami (Nowak-Dziemianowicz 2006). Stąd też bierze się niepodważalność wartości fundamentalnej, wynikającej z modelu DCF.

Jednak pojawiające się zdarzenia na rynkach finansowych, takie jak: niewyjaśnione spadki czy też wzrosty na giełdach, każą się zastanowić nad tym czy powszechnie panujący model wyceny jest zgodny z tym, jak wartość pojmują inwestorzy.

Dotychczas w literaturze przedmiotu pojawił się artykuł T. Dudycz i B. Brycz (2009) pt. Czy paradygmat wartości przeżywa kryzys?, w którym postawiono hipotezę dotyczącą kategorii obiektywnej. Mianowicie, istnienie wartości fundamentalnej, jako kategorii obiektywnej, nie ma uznania w praktyce oraz istnieją przesłanki ku temu, że kategoria ekonomicznej wartości przedsiębiorstwa przeżywa kryzys.

Utożsamiając wartość wewnętrzną w kuhnowskiej koncepcji rozwoju nauki, można zauważyć, że wartość fundamentalna (wynikająca z analizy fundamentalnej) stanowi swoisty paradygmat. Pojęcie to Kuhn zdefiniował jako: „powszechnie uznane osiągnięcia naukowe, które w pewnym czasie dostarczają społeczności uczonych modelowych problemów i rozwiązań" (Kuhn 2001, s. 12). Zgodnie z przytoczoną definicją, analiza fundamentalna wykształciła model, który wykorzystuje zaplecze metodologiczne do oszacowania wewnętrznej wartości przedsiębiorstw, służącej jako podstawa podjęcia decyzji przez inwestorów giełdowych. Jak wykazał wspomniany badacz w swojej koncepcji, w pewnym momencie pojawiają się anomalie, których dotychczasowy paradygmat nie wyjaśnia. Podjęcie działań, mających na celu wyjaśnienie pojawiających się anomalii oznacza prowadzenie badań w nowym kierunku. W konsekwencji podążanie w stronę nowej praktyki badawczej jest kryzysem, co warunkuje (według teorii Kuhna) rewolucję naukową, oznaczającą zmianę paradygmatu.

W świetle kuhnowskiej koncepcji rozwoju nauki, pojawiające się anomalie na rynkach finansowych mogą być symptomem tego, że obecnie panujący pozytywistyczny paradygmat nie spełnia swojej funkcji, czyli pojmowanie wartości przez inwestorów nie wynika tylko z analizy fundamentalnej. Celem artykułu jest wykazanie, że na rozumienie wartości przedsiębiorstw przez inwestorów giełdowych składa się wiele czynników, których siły oddziaływania nie da się do końca zmierzyć. Gdyż wiążą się z napływem i przetworzeniem informacji przez rynek. Dlatego też, powszechnie stosowany model wyceny przedsiębiorstw metodą DCF nie oddaje sposobu pojmowania wartości przez inwestorów. Cel pracy realizowany jest na czterech eta- 
pach. W pierwszym omówiono wartość fundamentalną oraz czynniki, które na nią oddziałują. Następnie wskazano przesłanki, że w obecnie panującym pozytywistycznym paradygmacie występują odchylenia. W kolejnym etapie scharakteryzowano hipotezę rynków efektywnych oraz asymetrię informacji i omówiono ich znaczenie w pojmowaniu wartości. W ostatnim opisano wpływ finansów behawioralnych na podejmowanie co poniektórych decyzji przez inwestorów giełdowych.

\section{Rodzaje wartości i ich znaczenie}

Wartość w ekonomii to pojęcie podstawowe. Ojciec współczesnej ekonomii, Adam Smith, rozpisywał się o ekonomii jako o „teorii wartości” (Jaki 2004, s. 20). Używane w ekonomii pojęcie „wartość” może za każdym razem oznaczać coś innego. Chociażby w wycenie przedsiębiorstw: przy zastosowaniu różnych metod wyceny informuje o czymś odmiennym, mimo że dotyczy jednego przedmiotu wyceny. Mówiąc o wycenie przedsiębiorstwa w kategoriach ekonomicznych, trzeba zaznaczyć, że jego wartość również jest traktowana jako wartość wymienna dobra, które jest przedmiotem wymiany rynkowej. Przedsiębiorstwa są dobrami o szczególnym charakterze, gdyż są niepomnażane lub trudno pomnażane (Jaki 2004). Skoro przedsiębiorstwo jest traktowane jako dobro wymiany, wiąże się z nim wartość użytkowa. Kategoria ta jest subiektywna, ponieważ niesie ze sobą kontekst psychologiczny, a także indywidualne upodobania inwestora (Jajuga i Jajuga 2006). Wartość użytkowa wykorzystuje zarówno fundamentalne decyzje konsumpcyjne, jak i inwestycyjne. A decyzja o ostatecznym rozliczeniu opiera się na podstawie zadowolenia lub użyteczności.

Rezultat połączenia wartości użytkowej i wymiennej wiąże się z racjonalnymi decyzjami inwestorów, czego wynikiem są podaż i popyt, co stanowi o tej właśnie wartości, którą Adam Smith nazwał „wartością naturalną” (Smith 1954, za: Jaki 2004, s. 22). W kreacji wartości naturalnej, spośród trzech głównych grup metod wyceny przedsiębiorstw (majątkowych, dochodowych oraz mieszanych), najczęściej wykorzystuje się metody dochodowe, ze względu na najbardziej przydatną i wiarygodną oszacowaną wartość.

Inwestorzy, patrząc na przedsiębiorstwo jako inwestycję, uznają ją jako wartość finansową. Wartość finansową można rozumieć w trzech aspektach - jako: ekonomiczną, fundamentalną i rynkową.

Wartość ekonomiczna rozumiana jest jako kategoria zdolności do generowania nadwyżek gotówki. Ma związek z wartością wymienną, ponieważ 
w tym kontekście wartość dobra definiuje się jako kwotę, którą inwestor jest teraz w stanie zapłacić, oczekując w przyszłości profitów (Zarzecki 1999). Ponadto wartość ekonomiczna wiąże się także z wartością użytkową, o której już wcześniej wspomniano. Posiadanie dobra, jakim jest m.in. przedsiębiorstwo, wiąże się z posiadaniem korzyści nazwanych przez A. Jakiego „dynamicznym kontekstem wartości” (2004, s. 23). Oznacza to zmianę w pojmowaniu kapitału z kategorii realnej w kategorię abstrakcyjną.

Wartość fundamentalna (wewnętrzna), jak już wspominano, rozumiana jest jako wartość obecna przyszłych przepływów pieniężnych (Tobin 1967; za: Panfil i Szablewski 2006, s. 484). Oddziałują na nią wszelkie dostępne informacje rynkowe w skali makroekonomicznej, a także wskaźniki giełdowe.

Wadą wartości fundamentalnej jest to, że zostaje naznaczona subiektywnością analityka, który ją wyznaczał, ponieważ nie wszystkie parametry dotyczące jej określenia są danymi rynkowymi. Zaprognozowane przyszłe przepływy pieniężne dyskontowane są odpowiednią stopą dyskontową, uwzględniającą ryzyko tych przepływów, zgodnie z modelem DCF. Model CAMP służy do obliczenia kosztu kapitału własnego, uwzględniając stopę wolną od ryzyka oraz premię za ryzyko (liczoną jako iloczyn indeksu ryzyka danej spółki i rynkowej premii za ryzyko). „Model ten wykazuje zależność pomiędzy stopami zwrotu a ryzykiem przy założeniu efektywności rynku na poziomie zagregowanym oraz racjonalnością inwestora na poziomie indywidualnym" (Zielonka 2011, s. 30). W przypadku stosowania dźwigni finansowej czynnikiem dyskontującym jest średnio ważony koszt kapitału (weighted average cost of capital - WACC), uwzględniający finansowania obce i własne.

Wartość fundamentalna, będąca wynikiem szacowania przedsiębiorstwa metodą dochodową, wykorzystywana jest w rekomendacjach maklerskich. Te z kolei, w teorii, mają dostarczać inwestorom podstaw do podejmowania decyzji w praktyce inwestycyjnej.

Wartość rynkowa to odwzorowanie postępowania uczestników rynku, czego rezultatem jest wielkość podaży i popytu, na podstawie których kształtuje się cena. Skoro inwestorzy składają zlecenia kupna/sprzedaży, powinni mieć uzasadnione podłoże do dokonania takich transakcji. Dlatego obecnie panuje założenie, że wartość rynkowa jest zdeterminowana wartością fundamentalną, która powinna dostarczać inwestorom takich podstaw.

Analiza fundamentalna jest to metoda badania, która zajmuje się rozpatrywaniem czynników determinujących cenę danego podmiotu. Jest w stanie odpowiedzieć na pytanie „Dlaczego?”. Skupia się na przyczynach zdarzeń zachodzących na rynku, w przeciwieństwie do analizy technicznej, skupiającej się tylko na skutkach (Murphy 1999). Dzięki temu podejściu wyznaczana 
jest wewnętrzna wartość spółki, która informuje o statusie wartości podmiotu, a dokładnie o jego niedowartościowaniu lub przewartościowaniu. Metoda fundamentalna, odnosząca się do wyceny przedsiębiorstwa, wiąże się z perspektywą długoterminową i obarczona zostaje subiektywną oceną analityka, dotyczącą chociażby parametrów dyskontowanych przepływów pieniężnych (Panfil i Szablewski 2006). Jednak mimo szczegółowej analizy od odpowiednich wskaźników makroekonomicznych do szczegółowych wskaźników danego przedsiębiorstwa wyznaczona cena jest opóźniona. „Ceny rynkowe wyprzedzają wiedzę fundamentalną" (Murphy 1999, s. 5). Maklerzy giełdowi szacują, że ceny rynkowe $\mathrm{z}$ wyprzedzeniem około 3-5 miesięcy dyskontują dostępną wiedzę fundamentalną. Dlatego też brakuje uniwersalnego algorytmu, dzięki któremu analitycy byliby w stanie ustalić cenę akcji na bazie aktualnych informacji fundamentalnych (Zielonka 2011), ponieważ każda informacja może mieć inny wpływ na wartość rynkową, niż by tego oczekiwano.

\section{Odchylenia od panującego pozytywistycznego paradygmatu}

Zanim T. Kuhn umiejscowił pojęcie anomalii w swojej koncepcji rozwoju nauki, słowo to było już wcześniej definiowane w wielu dziedzinach nauki. Jak napisał McGoun, pierwsze zapisane definicje sięgają 1581 r. I jak w przypadku nauk przyrodniczych anomalie znacząco przyczyniają się do rozwoju nowych i ostatecznie bardziej udanych teorii, tak w przypadku ekonomii finansowej anomalia odgrywa zupełnie inną rolę. Często używa się jej do wykazania odchyleń od modeli, na przykład modelu CAPM. Lecz ostatnio wykorzystuje się ją w nowej literaturze, współczesnej ekonomii, która kwestionuje niektóre z kluczowych założeń dotyczących tradycyjnych zachowań w finansach. Co więcej, anomalie w ekonomii finansowej odgrywają rolę w procesie odkrywania prawdy (Frankfurter i McGoun 2001). Są one także powszechnie akceptowalne i stanowią część „gry rynkowej”.

W powszechnej literaturze przedmiotu istnieje pogląd, że wartości rynkowe nie odzwierciedlają rzeczywistej wartości przedsiębiorstw. Za ten stan winę zrzuca się na krótkowzroczność inwestorów - zarówno indywidualnych, jak i korporacyjnych - przez co ceny rynkowe nie odzwierciedlają wewnętrznych wartości przedsiębiorstwa, które skupiają się na długofalowych celach (Stalmach 2005). Dlatego też wielu inwestorów wyczekuje sprawozdań finansowych, aby dowiedzieć się, jak wygląda sytuacja finansowa z perspektywy księgowości. Po publikacji takich informacji na rynku mają miejsce znaczące 
spadki lub wzrosty, co może podważać wartość fundamentalną. Przykładem takiej sytuacji jest spadek akcji TPSA w lutym 2013 r. - po publikacji jej sprawozdań finansowych za IV kwartał 2012 r. kurs akcji tej spółki spadł o 27\%. Trzeba zaznaczyć, że perspektywa księgowa jest trudnym kryterium porównującym, a mimo to często publikacja sprawozdań finansowych jednego podmiotu zmienia kurs akcji spółki konkurencyjnej. Co jest przejawem tego, że inwestorzy nie trzymają się kurczowo długoterminowej wyceny wynikającej $\mathrm{z}$ modelu DCF.

$\mathrm{Na}$ wycenę wpływa niewątpliwie wiele czynników. Jednym z nich jest informacja, która czasem: jest w nadmiarze dla osób uprzywilejowanych oraz bywa niewystarczająca dla pozostałych interesariuszy. Wpływ polityki informacyjnej przedsiębiorstwa jest pomijany przez analizę fundamentalną. Wyjątkami są obligatoryjne sprawozdania finansowe, w których mieszczą się kluczowe kategorie, nieodzwierciedlające pełnej sytuacji finansowej przedsiębiorstwa. Firmy same dostarczają nieodpowiedniej lub lakonicznej informacji, która może mieć wpływ na decyzje inwestorskie, w konsekwencji spółki mogą być przewartościowane lub niedoszacowane. Jak wynika z badań przeprowadzonych przez Stowarzyszenie Inwestorów Indywidualnych, inwestorzy są skłonni zapłacić więcej za spółki, które uprawiają politykę długofalowej informacji z rynkiem (Kucharczyk 2013). Różnice pomiędzy wartością fundamentalną, jaką postrzegają uczestnicy rynku, a tą postrzeganą przez analityków mogą być spowodowane samą metodą wyceny DCF. Niesie ona bowiem zbyt dużą nieścisłość przy wycenie spółki poprzez zbyt subiektywną ocenę ryzyka, prognoz przepływów pieniężnych czy też wartości rezydualnej, która plasuje się często powyżej 50\% (Dudycz i Brycz 2009). To powoduje, że sam model może nie mieć potwierdzenia w rzeczywiście wypracowanych wynikach spółki.

Pojawiające się nagłe zmiany indeksów giełdowych, których nie można wyjaśnić za pomocą analizy fundamentalnej, są przykładami anomalii w panującym paradygmacie. Najbardziej znanym odchyleniem, którego zaistnienie nie było wynikiem fundamentalnych warunków, jest największy spadek indeksu giełdowego Dow Jones Industrial Average z 19 października 1987 r. Indeks ten stracił jedną piątą swojej wartości i był to spadek niemal dwukrotnie większy niż podczas krachu giełdowego w 1929 r. Podobna sytuacja, lecz bardzo krótkotrwała, miała również miejsce na nowojorskiej giełdzie 6 maja 2010 r., gdzie zanotowano około 9\% spadek w przeciągu kilkunastu minut. Natomiast w drugiej połowie maja 2013 r. indeks tureckiej giełdy XU100 spadł o 20\% w przeciągu dwóch tygodni, również bez jakichkolwiek fundamentalnych przesłanek. Spadki czy też wzrosty na jednej gieł- 
dzie, szczególnie dużej, prowadzą do tego samego na innych giełdach, gdyż są źródłem czynników giełdowych oddziałujących na wielkość popytu i podaży na rynkach akcji.

5 grudnia 1996 r. A. Greenspan użył znamiennych słów opisujących zachowanie inwestorów: „irracjonalny entuzjazm”, przez co na światowych giełdach w pewnym momencie w ciągu dnia nastąpiły gwałtowne spadki, takie jak: japoński indeks Nikkei - 3,2\%, w Hongkongu Hang Seng - 2,9\%, w Niemczech DAX - 4\%, natomiast londyński indeks FT-SE 100 - 4\%. Także w Stanach Zjednoczonych Dow Jones Industrial Average spadł o 2,3\%, na rozpoczęciu sesji. Zdaniem Shillera słowa Greenspana sugerowały możliwość, że na giełdzie mogą pojawiać się spadki lub przynajmniej może stać się mniej obiecującą inwestycją (Shiller 2000). Tak na prawdę te przypuszczenia nie miały żadnych podstaw. Historia pokazała, że wzrosty choćby na nowojorskiej giełdzie, były nieproporcjonalnie większe niż wzrosty płac w Stanach Zjednoczonych.

Odchylenia wykazują nie tylko indeksy giełdowe, lecz także pojedyncze kursy akcji spółek. W połowie lutego 2009 r. akcje banku PEKAO SA spadły o prawie 19\% (mimo wysokich obrotów) bez jakichkolwiek powodów fundamentalnych.

Można również wyróżnić typowe błędy behawioralne, jak: efekt przełomu miesiąca, sell in may and go away czy panująca euforia na światowych rynkach w 2007 r., choć napływały sygnały o występowaniu bańki spekulacyjnej na rynku mieszkaniowym (Żurawik 2012).

Wykazane odchylenia od obecnie panującego pozytywistycznego paradygmatu są przejawem tego, że podejmowanie decyzji inwestorskich nie jest rezultatem stosowania analizy fundamentalnej jako naczelnego narzędzia decyzyjnego, lecz wspomagającego. Jest to spowodowane tym, że analiza fundamentalna ma zbyt wąski charakter, który nie uwzględnia subiektywnych uwarunkowań inwestorskich lub narzuca zbyt wyśrubowany model DCF, nieprzekładający się na warunki rzeczywiste. Jak wynika z powyższych przykładów, nawet pojawienie się opinii może przyczynić się do ruchów cen akcji. Dlatego też kluczowe znaczenia ma to, co dociera na rynek oraz jak tę informację on przetworzy. To pierwsze wiąże się z istnieniem asymetrii informacji, natomiast to drugie $-\mathrm{z}$ hipotezą rynków efektywnych, którym będzie poświęcony kolejny rozdział.

Bliższe przyjrzenie się czynnikom, które powodują odchylenia, może przyczynić się do zlokalizowania miejsca, w którym obecnie panujący paradygmat nie pokrywa się z pojmowaniem wartości przez inwestorów. Dlatego prowadzenie badań, które miałyby na celu wytłumaczenie powyższych, a także 
i innych niewytłumaczalnych zjawisk zachodzących na giełdach, warunkowałby kryzys w obecnym paradygmacie.

\section{Rynek efektywny a asymetria informacji}

Analizę fundamentalną łączy się z hipotezą rynku efektywnego, gdyż uwzględnia ona napływające informacje fundamentalne. Jest to zgodne z założeniem pozytywizmu, że na bazie systematycznych obserwacji można mierzyć i prognozować.

Rynek, który odzwierciedla w cenach akcji, natychmiast, wszystkie napływające informacje, został nazwany rynkiem efektywnym. Przez co nie jest możliwe osiągnięcie ponadprzeciętnych zysków. Założeniem istnienia takiego rynku jest to, że inwestorzy są od siebie niezależni i podejmują racjonalne decyzje, a informacje mające wpływ na cenę walorów są od siebie niezależne i napływają losowo (Piontek i Papla 1999).

Na przestrzeni lat hipoteza rynku efektywnego rozwijała się poprzez dołączanie do niej zaplecza nowych elementów, które mogłyby lepiej wyjaśnić cenę walorów, choćby przez dodatnie kosztów transakcyjnych czy też asymetrii informacji (Potocki i Świst 2009). Wszystkie prace badawcze wciąż opierają się jednak na podstawowej hipotezie rynku efektywnego, sformułowanej przez E. Famę oraz skorygowanej przez niego jej pierwotnej definicji: „rynek efektywny to rynek, gdzie ważne informacje bieżące są prawie bezkosztowo dostępne dla wszystkich uczestników oraz na którym aktywnie współzawodniczy duża liczba racjonalnie postępujących inwestorów działających z nastawieniem na maksymalizację zysku i starających się przewidzieć rozwój kursu akcji. Na rynku efektywnym konkurencja pomiędzy jego inteligentnie postępującymi uczestnikami doprowadza do tego, że bieżąca cena akcji w każdym momencie odzwierciedla informacje związane z przeszłymi wydarzeniami oraz wydarzeniami, które dopiero zajdą na rynku" (Fama 1990, za: Gabryś 2006, s. 7). Fama wyróżnił trzy formy rynku efektywnego ze względu na zakres informacji (Fama 1970, za: Piontek i Papla 1999, s. 287-298): słabą, średnią i silną efektywność rynku.

Słaba efektywność charakteryzuje się tym, że cena odzwierciedla wszystkie możliwe informacje przeszłe, na przykład obroty czy liczbę transakcji. Dlatego też analiza techniczna nie ma w tym przypadku racji bytu. Średnia efektywność oznacza, że cena akcji odzwierciedla nie tylko informacje giełdowe, ale także wszelkie dostępne informacje publiczne. Więc stosowanie regularnie zarówno analizy fundamentalnej, jak i technicznej również nie przyniesie 
większych zysków. Przy ostatniej formie efektywności cena akcji zawiera oprócz zawartych wszystkich informacji, jak w przypadku półefektywności, również informacje poufne, niedostępne dla rynku. Według tej hipotezy, ceny rynkowe powinny wiernie odzwierciedlać wszystko to, co dzieje się na rynku gospodarczym oraz „odzwierciedlać prognozy oczekiwanych strumieni pieniężnych generowanych w przyszłości” (Dudycz i Brycz 2009, s. 321).

„Wszystkie trzy wyrażają ogólną ideę, że z wyjątkiem długookresowych trendów, przyszłe ceny akcji są trudne, jeśli nie niemożliwe do przewidzenia" (Malkiel 2007; za: Bitner 2009, s. 4). Z wielu badań wynika, że prognozowanie przyszłych kursów akcji obarczone jest dużym prawdopodobieństwem błędu, ponieważ istnieje niska korelacja pomiędzy kursami historycznymi. Dlatego też prawdopodobieństwo osiągniecie ponadprzeciętnych zysków na bazie historycznych notowań jest bliskie zera.

McGoun porównuje efektywność rynków tylko do maszynki wykonującej transformację cen, ponieważ ceny powinny poruszać się tylko w odpowiedzi na otrzymane nowe informacje z przyszłości (2008). Nieznajomość informacji jest źródłem ryzyka, a jeśli mamy doskonałe informacje, ceny będą odzwierciedlać nieodłączne wartości i nie będzie ryzyka. Jest to metafora, że rynki są maszynami wykonującymi transformację cen (po wejściu danych informacji). Podczas gdy informacje mogą dotrzeć losowo, w związku z tym ceny różnią się losowo. Proces transformacji jest zdecydowanie nieprzypadkowy. Ryzyko nie pochodzi z rynków, ale z otoczenia rynków, z których pochodzą informacje napływające na ten rynek.

Biorąc jednak pod uwagę wymienione wcześniej odchylenia - bezprzyczynowe spadki czy też ponadprzeciętne wzrosty, których również nikt nie prognozował, trudno zgodzić się z hipotezą rynków efektywnych. Kluczowe znaczenie ma czy każdy inwestor uwzględnia napływające informacje w ten sam sposób, a także czy podejmuje decyzje racjonalnie i niezależnie od innych?

Dla tego rynku charakterystyczny jest paradoks efektywności (Zielonka 2011). Polega on na tym, że im bardziej uczestnicy rynku uwierzą w jego istnienie i nie wykażą chęci do szukania odstępstw od niego, tym mniej efektywny będzie stawał się rynek. Czyli im większa wiara w jego efektywność, tym mniejsza jego rzeczywista efektywność. Ów paradoks spowodowany jest tym, że efektywność nie jest cechą rynku, która jest mu nadana na zawsze, ale jego efektywność właśnie zależy od zachowania inwestorów, wynikającego z pojmowania przez nich wartości i interpretacji napływających do nich informacji. Jednak czy wartość rynkowa odzwierciedla wtedy wartość fundamentalną, czy krótkotrwałe nastroje giełdowe? 
W opozycji do założeń rynku efektywnego stoi asymetria informacji, która jest definiowana „najczęściej jako sytuacja, w której jedna ze stron transakcji posiada większy zasób informacji na temat danej wymiany rynkowej niż druga strona" (Polański, Pietrzak i Woźniak 2008; za: Sieroń 2010, s. 1). Taka sytuacja bardzo często występuje zarówno na rynku transakcji kupna-sprzedaży walorów giełdowych, jak i na co dzień w życiu każdego człowieka.

Zgodnie $\mathrm{z}$ istnieniem rynku efektywnego, nie ma znaczenia różnica pomiędzy inwestorem początkującym a inwestorem $\mathrm{z}$ długim stażem, ponieważ obaj i tak bazują na tych samych informacjach (Majewski 2004). Jednakże rzeczywistość wygląda zupełnie inaczej niż zakładałby rynek efektywny. Przede wszystkim dlatego, że na rynku obrotu giełdowego występuje wiele stron, które muszą być zaangażowane w obrót papierami wartościowymi na rynku regulowanym. Każda ze stron, mimo pełnienia innej funkcji w tym obiegu zamkniętym, chce czerpać korzyść dla siebie. Korzyści te nie zawsze są zbieżne z korzyściami innych, wyjątek stanowią (prawnie powinny stanowić) podmioty regulujące i nadzorujące. W związku z tym pojawiają się na rynku informacje. S. Forlicz wyróżnia dwa podstawowe determinanty przepływu informacji (2001, za: Karaban b.d., s. 4). Pierwszy z nich ma na celu poprawę stanu wiedzy, dotyczącej kupna potencjalnych papierów wartościowych, co pozwoli inwestorowi na osiągnięcie w przyszłości większych zysków. Drugi determinant dąży do wprowadzenia innych uczestników „gry rynkowej” w błąd w celu poprawy swojej pozycji wśród konkurencji. Ponadto, nie każdy inwestor interpretuje napływające informacje rynkowe w ten sam sposób, jak wynikałby to z założeń rynku efektywnego. Do tego każdy z nich może stosować inną strategię inwestycyjną, która pomogłaby mu osiągnąć wyższą stopę zwrotu. Dlatego starając się wyprzedzić rynek, podchodzą oni do informacji w sposób odmienny niż wynikałoby to z teoretycznych założeń. Co więcej, w wyniku asymetrii informacji, brak niezbędnych informacji służących podjęciu decyzji inwestorskiej wspomaga podejmowanie irracjonalnych decyzji przez inwestorów, co w konsekwencji wprowadza zaburzenia na rynkach finansowych.

Tak więc na rynek kapitałowy wpływa wiele czynników związanych $\mathrm{z}$ dostarczeniem informacji i jej interpretacją, co powoduje, że nie jest on sztywnym wytworem. Swoją plastyczność zawdzięcza skutkom decyzji inwestorskich, a same decyzje inwestorskie niosą brzemię ludzkiego subiektywizmu. Jak pisał M. Bitner, „Za ruchami cen stoją miliardy decyzji, myśli i innych celowych działań - rynek jest wytworem człowieka, efektem i miejscem koordynacji jego planów, a nie dziełem przypadku" (2009).

Łącząc oba skrajne podejścia, rynek na pewno uwzględnia wszystkie napływające nowe informacje, lecz stopień oddziaływania każdej z nich na 
decyzje inwestorów jest zależny od tego od momentu odbioru informacji oraz tego jaką ma ona wagę dla poszczególnego gracza giełdowego. Poza tym nie wszystkie napływające na rynek informacje są uwzględnianie w modelu DCF, mimo iż stanowi on dość zaawansowane narzędzie szacowania wartości.

\section{Zachowanie inwestorów}

Nauka zajmująca się badaniem decyzji inwestorskich w mikroskali, w warunkach niepewności i ryzyka, a także ich przyczyn psychologicznych i emocjonalnych $w$ literaturze została nazwana finansami behawioralnymi. Jest to część ekonomii behawioralnej, która dotyczy skali makro; nauka ta jest przeciwna do klasycznego paradygmatu finansów, który zakłada racjonalność inwestorów (paradygmat homo economicus), a ich nieracjonalność jest anomalią. Natomiast finanse behawioralne akceptują nieracjonalność inwestorów, uważają je za regułę, a także skupiają się na mikroanalizie zachowań jednostek na rynku finansowym (Cieślak 2003) na podstawie eksperymentów. Również racjonalność inwestorów różnicuje nowoczesną teorię portfelową i psychologię rynków finansowych. W tej pierwszej inwestorzy podejmują racjonalne decyzje w celu maksymalizacji swojej użyteczności, badacze ekonomii behawioralnej wykazują zaś, że człowiek nie jest w stanie zawsze posługiwać się racjonalnością, a wspomaga się różnego rodzaju heurystykami, czyli ograniczonym dostępem do informacji i prozaicznym sposobem radzenia sobie ze skomplikowanymi problemami (Panfil i Szablewski 2006), co także podważa istnienie rynku efektywnego.

Znamienne dla finansów behawioralnych jest to, że ludzie w warunkach niepewności podejmują decyzje pod wpływem emocji, które są wywoływane ową niepewnością (Żurawik 2012).

W głównej mierze finanse behawioralne zostały rozpowszechnione przez badania Tversky'ego i Kahnemana - dzięki wprowadzeniu przez nich teorii perspektywy, która jest rozszerzeniem teorii oczekiwanej użyteczności (Cieślak 2003). Na jej podstawie wytłumaczono co poniektóre heurystyki, używane przez nieracjonalnego inwestora, jak na przykład: krótkowzroczną awersję do strat, uleganie efektowi dyspozycji czy podatności na wpływ utopionych kosztów, których nie tłumaczyła teoria oczekiwanej użyteczności. Ponadto, teoria perspektywy jest w stanie uchwycić zmienność relacji danej jednostki do ryzyka (Cieślak 2003), które jest nieuniknione w procesie inwestycyjnym. 
Tversky i Kahneman prowadzili badania nad irracjonalnością inwestorów. $\mathrm{Z}$ ich badań wynika, że inwestorzy przywiązują większą wagę do strat aniżeli do zysków, przez co reakcje na zyski i straty są niesymetryczne. Skutkuje to tym, że niewielkie zyski skłaniają inwestora do sprzedaży papierów wartościowych w celu uniknięcia strat. Straty natomiast wywołują negatywne emocje, choćby poczucie wstydu (Żurawik 2012).

Nieracjonalność inwestorów i wykorzystywane przez nich heurystyki powodują, że odbierane przez nich bodźce $\mathrm{z}$ rynku nie zawsze są poprawne oraz nie zawsze są poprawnie interpretowane. Co więcej, inwestorzy mogą selekcjonować otaczające ich informacje, które nie są sprzeczne z ich opiniami lub pomijać te, które są (Żurawik 2012). Te interpretacje skutkują zaś decyzjami inwestycyjnymi, które trafiają z powrotem na rynek, zamykając ten cykl - nazwanym przez G. Sorosa - dualizmem nauk społecznych. A tego mechanizmu nie uwzględnia żadna teoria związana $\mathrm{z}$ wyceną przedsiębiorstw. Analiza fundamentalna i finanse behawioralne nawzajem się uzupełnią (Zielonka 2011). Ponieważ rynkowe ceny akcji tylko do jakiegoś momentu są wyjaśniane na podstawie czynników fundamentalnych, a reszta to elementy psychologiczne, odnoszące się do indywidualnych decyzji uczestników rynku. Jednakże zbadanie wpływu tych wszystkich indywidulanych czynników na tak dużą skalę jest bardzo trudne, o ile nie niemożliwe.

Przyjęcie założeń behawiorystów podważa pozytywistyczny paradygmat między innymi dlatego, że nieracjonalność inwestorów jest sprzeczna z przyjęciem tej samej prawomocnej konkluzji z badania (wyceny) przez wszystkich inwestorów. Ponadto, w świetle tej nieracjonalności wartość wewnętrzna przedsiębiorstwa przestaje być obiektywną wartością, a staje się wartością użytkową.

\section{Zakończenie}

Wartość fundamentalna, zgodnie z pozytywistycznym paradygmatem, ma służyć inwestorom giełdowym w dostarczaniu wiadomości na temat fundamentów istnienia i rozwijania się przedsiębiorstwa w długiej perspektywie. Na proces pojmowania wartości wpływa wiele czynników o zróżnicowanych wagach, przez co wartość przedsiębiorstw ma dla każdego inwestora indywidualną wartość wymienną i użytkową. Na czynniki te oddziałują sygnały, które stanowią podstawę podejmowania decyzji na giełdach. W głównej mierze trzeba wziąć pod uwagę ustalenia behawiorystów, którzy twierdzą, że ludzkie myślenie z złożenia naznaczone jest piętnem nieracjonalności. Łączą 
się one z czynnikami psychologicznymi, takimi jak na przykład emocje, które niejednokrotnie mają wpływ na popyt i podaż na giełdach. Dodatkowo zjawiska socjologiczne na przykład „owczy pęd”, panika czy mechanizm handlu giełdowego potęgują siłę zjawisk występujących na rynkach, zamiast wpływu ważnych, fundamentalnych informacji, które i tak są w rozmaity sposób przetwarzane. Wymienionych powyżej czynników oraz sygnałów nie uwzględnia powszechnie stosowany model DCF, mimo swojej wysublimowanej specjalizacji, staje się jednym $\mathrm{z}$ wielu punktów podparcia, a nie podwaliną decyzji inwestorskich.

Trzeba zwrócić uwagę także na to, że rekomendowane wartości fundamentalne niejednokrotnie służą do osiągnięcia „specyficznych” pośrednich lub bezpośrednich celów przez ich twórców. W konsekwencji może to powodować brak ufności inwestorów do wartości fundamentalnej, którzy będą uważać ją za nieautentyczną. Dodatkowo, zbyt prozaiczne założenia w modelu DCF są przyczyną tego, że rekomendowana wartość jest niewiarygodna. Ponadto, nieraz rekomendowana wartość fundamentalna składa się z procentowego udziału różnych metod wyceny. Na przykład rekomendowana wartość docelowa zawiera $80 \%$ wartości wynikającej z modelu DCF, a $20 \%$ wartości stanowi rezultat wyceny metodą porównawczą. To z kolei oddala oszacowaną, nową wartość od rzeczywistej wartości fundamentalnej, gdyż nie jest ona szacunkiem wewnętrznych determinantów wartości, lecz uwzględnieniem w jakimś ułamku nastrojów giełdowych.

Dlatego też, powszechnie stosowane modele wyceny przedsiębiorstw nie oddają jakości pojmowania wartości przez inwestorów giełdowych, czego dowodzą pojawiające się anomalie na rynkach. Inwestorzy nie podążają tylko za wartością fundamentalną, czyli za wewnętrznymi przesłankami płynącymi z przedsiębiorstw i gospodarek, w której działają, lecz za wartością, która wynika $\mathrm{z}$ ich subiektywnego pojmowania każdego z przedsiębiorstw. W związku z czym, nie można mówić o wartości jako kategorii obiektywnej w ujęciu pozytywistycznym, gdyż jest ona nacechowana czynnikami wartościującymi.

Czy w ogóle istnieje zatem wartość fundamentalna, która obiektywnie opisywałaby wartość przedsiębiorstw pojmowaną przez inwestorów? Dalsze badania nad występującymi niewyjaśnionymi odchyleniami (które przyczyniają się do destabilizacji rynku), mogą pomóc sprecyzować nowy paradygmat, który lepiej oddawałby jakość pojmowanej wartości. Jest to problem ważny, którego rozwiązanie może przyczynić się do zmniejszenia niepewności i ryzyka na rynku, a który na pewno będzie przełomem we współcześnie panującej koncepcji ekonomii. Zgodnie z kuhnowską teorią rozwoju nauki, 
stary paradygmat zostaje zastąpiony nowym, jeśli jest w stanie wyjaśnić to, czego wcześniejszy już nie objaśniał. Zatem czy dojdzie do rewolucji, czy zakończy się tylko na kryzysie?

\section{Bibliografia}

Bitner, M. (2009). Czy Hipoteza Efektywnego Rynku Finansowego ma implikacje inwestycyjne?, e-Finanse. Finansowy kwartalnik internetowy, 4.

Cieślak, A. (2003). Behawioralna ekonomia finansowa. Modyfikacja paradygmatów funkcjonujacych w nowoczesnej teorii finansów. Warszawa: Narodowy Bank Polski.

Dudycz, T., Brycz, B. (2009). Czy paradygmat wartości przeżywa kryzys?. Zeszyty Naukowe Uniwersytetu Szczecineckiego (534) Finanse, Rynki Finansowe, Ubezpieczenia, 17.

Frankfurter, G., McGoun, E. (2001). Anomalies in finance. What are they and what are they good for?, International Review of Financial Analysis, 10. DOI:10.1016/S10575219(01)00061-8

Gabryś, A. (2006). Efektywność rynku kapitałowego: poszukiwania teoretyczne i obserwacje empiryczne. Warszawa: Fundacja Aurea Mediocritas.

Jajuga, K., Jajuga, T. (2006). Inwestycje. Instrumenty finansowe. Aktywa niefinansowe. Ryzyko finansowe. Inzynieria finansowa. Warszawa: Wydawnictwo Naukowe PWN.

Jaki, A. (2004). Wycena przedsiębiorstwa. Przestanki, procedury, metody. Kraków: Oficyna Ekonomiczna.

Karaban, B. (b.d.). Zjawisko asymetrii informacyjnej i niewiedzy uczestników rynku na przyktadzie rynku kapitałowego w Polsce. Kurs: Giełda Papierów Wartościowych i rynek kapitatowy. Pobrano z: http://www.kapital.edu.pl/pliki/wyroznione_prace/B_Karaban-Asymetria_informacyjna_i_niewiedza_uczestnikow_rynku_KARABAN.pdf (dostęp: 05.02.2013).

Kucharczyk, $\overline{\mathrm{K}}$. (2013). Dobra polityka informacyjna to nie banał. Naprawdę się opłaca, Gazeta Gietdy PARKIET, 46(5074), luty.

Kuhn, T. (2001). Struktura rewolucji naukowych. Warszawa: Fundacja Aletheia.

Majewski, S. (2004). Inwestowanie $w$ warunkach nadmiaru informacji. Pobrano z: http:// mikroekonomia.net/en/library/76 (dostęp: 11.02.2014).

McGoun, E. (2008). The inherent manipulability of markets, Accountancy Business and the Public Interest, 7(2).

Murphy, J. (1999). Analiza techniczna rynków finansowych. Warszawa: WIG-PRESS.

Panfil M. i Szablewski A. (red.). (2006). Metody wyceny spótki. Perspektywa klienta i inwestora. Warszawa: Poltext.

Parker, R. (1968). Discounted Cash Flow in historical Perspective, Journal of Accounting Research, 6(1), Spring, University of Chicago, Accounting Research Center, Booth School of Business. Pobrano z: http://www.jstor.org/stable/2490123?seq=1 (dostęp: 31.08.201).

Piontek, K. i Papla, D. (1999). Próba zastosowania wielokryterialnego wspomagania decyzji w badaniu efektywności rynków kapitałowych. W: Dynamiczne modele ekonometryczne. VI Ogólnopolskie Seminarium Naukowe - Toruń, wrzesień 1999 r. Materiały konferencyjne. Toruń: Uniwersytet Mikołaja Kopernika w Toruniu.

Potocki, T. i Świst, T. (2009). Polski rynek kapitałowy vs hipoteza rynków efektywnych weryfikacja paradygmatu, e-Finanse. Finansowy kwartalnik internetowy, 1.

Shiller, R. (2000). Irrational Exuberance. Princeton. New Jersey: Princeton University Press. 
Sieroń, A. (2010). Krytyczne podejście do mainstreamowego ujęcia asymetrii informacyjnej. Fundacja Instytutu Ludwiga von Misesa. Pobrano z: http://mises.pl/wp-content/uploads/2010/09/Krytyczne-podejscie-do-mainstreamowego-ujecia-asymetrii-informacyjnej.pdf (dostęp: 30.01.2013).

Stalmach, R. (2005). Zarzadzanie firma $w$ interesie akcjonariuszy. Warszawa: Difin.

Tatarkiewicz, W. (1978). Parerga. Warszawa: Wydawnictwo Naukowe PWN.

Zarzecki, D. (1999). Metody wyceny przedsiębiorstw. Warszawa: Fundacja Rozwoju Rachunkowości.

Zielonka, P. (2011). Gietda i psychologia. Behawioralne aspekty inwestowania na rynku papierów wartościowych. Warszawa: CeDeWu.PL.

Żurawik, B. (2012). Irracjonalność zachowań inwestorów giełdowych. Prace i Materiały Wydziału Zarządzania Uniwersytetu Gdańskiego, Zarządzanie i Finanse, 2. 


\title{
Rozdział III
}

\author{
TERESA CZERWIŃSKA*
}

\section{Asymetria informacji na giełdowym rynku akcji \\ - raportowanie danych pozafinansowych przez spółki publiczne \\ na Giełdzie Papierów Wartościowych w Warszawie}

\begin{abstract}
Streszczenie
W rozdziale przedstawiono: (1) analizę i ocenę raportowania danych pozafinansowych w zakresie ESG przez spółki notowane na rynku publicznym w Polsce; (2) identyfikację zakresu przedmiotowego luki informacyjnej w zakresie raportowania danych pozafinansowych przez spółki publiczne. Zakres czasowy badań obejmuje lata 2012-2013. Badaniem objęto całą populację spółek publicznych notowanych na GPW oraz rynku New Connect w analizowanym okresie.
\end{abstract}

Słowa kluczowe: asymetria informacji, raportowanie danych pozafinansowych, ESG, spółki publiczne.

\begin{abstract}
Abstact
The paper presents: (1) an analysis and evaluation of reporting non-financial data in terms of ESG by companies listed on the public market in Poland; (2) identify the scope of the information gap in the field of non-financial data reporting by public companies. The scope of the research includes the time period 2012-2013. The study included the entire population of public companies listed on the Warsaw Stock Exchange and the New Connect market during the period.
\end{abstract}

Keywords: asymmetry of information, non-financial data reporting, ESG, public companies.

Prof. nzw. dr hab. Teresa Czerwińska - Katedra Systemów Finansowych Gospodarki, Zakład Ubezpieczeń i Rynków Kapitałowych, Wydział Zarządzania, Uniwersytet Warszawski; e-mail: tczerwińska@wz.uw.edu.pl. 


\section{Wstęp}

W klasycznym ujęciu inwestor podejmuje decyzje inwestycyjne, biorąc pod uwagę dwa kluczowe parametry: oczekiwaną stopę zwrotu oraz poziom ryzyka inwestycyjnego. Ocena tych parametrów dokonywana jest przede wszystkim na podstawie publicznie dostępnej informacji dostarczanej zarówno przez spółkę, jak i przez pozostałych uczestników rynku kapitałowego, tj. analityków, doradców, organ nadzorczy, innych inwestorów etc. Obowiązki informacyjne emitentów papierów wartościowych na rynku publicznym dotyczą przede wszystkim informacji w zakresie kondycji ekonomicznofinansowej, to jednak, jak pokazują doświadczenia, kreowanie wartości spółki ma, po pierwsze, wymiar nie tylko finansowy, po drugie zaś - wymaga trwałego łączenia zarządzania w wymiarze ekonomicznym, społecznym i środowiskowym (tzw. Triple Bottom Line) tak na poziomie przedsiębiorstwa, jak i całej gospodarki (tzw. rozwój zrównoważony). We współczesnej gospodarce globalnej, gdzie bariery przepływu kapitału, towarów oraz zarządzających są w znacznej mierze likwidowane, przedsiębiorstwa upatrują bowiem swojej szansy na kreowanie wartości poprzez budowanie wzajemnych relacji z grupami interesariuszy, zaliczając ich obok kapitału intelektualnego i organizacyjnego do aktywów niematerialnych o fundamentalnym znaczeniu rozwojowym (zob. Stalmach 2005, s. 79; Szablewski 2004, s. 40-42).

Jak wykazują badania na rynkach światowych, obecnie wartość rynkowa przedsiębiorstwa kształtowana jest zaledwie w $1 / 5$ przez aktywa materialne (w 1975 roku stanowiły one 83\% wartości rynkowej przedsiębiorstwa), natomiast resztę dopełniają kategorie niematerialne (Ocean Tomo 2011, za: MG 2013), tj. kapitał ludzki, relacje z interesariuszami, reputacja. Ujawnianie danych pozafinansowych umożliwia kompletną holistyczną ocenę ryzyka przedsiębiorstwa i wycenę jego wartości. Czynniki związane ze środowiskiem naturalnym, społeczeństwem oraz ładem korporacyjnym (ESG: Environment, Social, Corporate Governance) generują ryzyko równie istotne w ocenie inwestycji, co dane finansowe. Pojawia się zatem coraz silniej akcentowana potrzeba wkomponowywania w proces inwestycyjny (w mniejszym lub większym stopniu) oprócz kryteriów stricte ekonomicznych, wartości etycznych, interesów społecznych, ekologicznych oraz dialogu z interesariuszami (The Principles for Responsible... 2007).

Celem opracowania jest: (1) analiza i ocena raportowania danych pozafinansowych w zakresie ESG przez spółki notowane na rynku publicznym w Polsce; (2) identyfikacja zakresu przedmiotowego luki informacyjnej w zakresie raportowania danych pozafinansowych przez spółki publiczne. 
Zakres czasowy badań obejmuje lata 2012-2013. Badaniem objęto całą populację spółek publicznych notowanych na GPW oraz rynku New Connect w analizowanym okresie, łącznie 831 spółek w 2012 roku oraz 853 spółki w 2013 roku. W badaniu wykorzystano metodologię oceny raportowania danych pozafinansowych spółek wg GES Risk Rating.

\section{Asymetria informacji w zakresie danych pozafinansowych - luka informacyjna}

W świetle sformułowanej przez E. Famę (1970, s. 373-417; 1991, s. 1575-1617), fundamentalnej dla rynku kapitałowego hipotezy efektywności (Efficiency Market Hypothesis), rynek w sposób ciągly dyskontuje dostępne informacje w cenie notowanych papierów wartościowych. Rynki mogą się różnić poziomem efektywności informacyjnej. Zakres dostępnych inwestorom informacji oraz ich kompletność i rzetelność ma wpływ na poziom asymetrii informacyjnej na rynku kapitałowym. Biorąc pod uwagę, że profil ryzyko - dochód portfela inwestycji jest wypadkową czynników mierzalnych stricte ekonomiczno-finansowych oraz pewnych parametrów pozafinansowych cechujących emitenta instrumentu finansowego, tj.: społeczne, środowiskowe oraz związane z ładem korporacyjnym (ESG), inwestorzy i zarządzający portfelem podejmując decyzje, poszukują informacji dotyczących nie tylko parametrów ekonomicznych i finansowych spółki, lecz także podejmują się (w sposób pośredni lub bezpośredni) oceny ryzyka inwestycyjnego związanego z działalnością spółki w wymiarze społecznym oraz jej wpływu na środowisko naturalne. Skutki asymetrii informacyjnej obserwowalne są po obu stornach uczestników rynku kapitałowego, zarówno wśród inwestorów i zarządzających portfelem, jak i wśród emitentów. Ryzyko związane z asymetrią informacyjną w zakresie danych pozafinansowych ESG - postrzegane z perspektywy emitenta - związane jest przede wszystkim z ryzykiem nieosiągnięcia założonego wyniku finansowego wskutek ujawnienia „informacji wrażliwych", np. dotyczących praktyk w zakresie reklamacji lub zatrudniania, szkolenia i wynagradzania pracowników, ponoszenia dodatkowych kosztów związanych z sankcjami lub ostracyzmem społecznym oraz ryzykiem utraty dobrej reputacji i wiarygodności zarówno wśród konsumentów, jak i kontrahentów (European Asset Owners... 2010). Natomiast z perspektywy inwestorów ryzyko związane z ESG rozpatrywane jest głównie w aspekcie ryzyka reputacji inwestora oraz efektywności portfela (Czerwińska 2013, s. 69-80). Z kolei emitenci poszukują związków między corporate governance 
a wartością przedsiębiorstwa i jego zdolnością do generowania ponadprzeciętnych stóp zwrotu w długim okresie (Gompers, Ishii i Metrick 2003, s. 107-155).

Inwestorzy argumentują, że wskutek asymetrii informacyjnej dotyczącej ujawniania danych pozafinansowych związanych z praktykami zaliczanymi do obszaru społecznej odpowiedzialności emitenta, możliwe jest uzyskanie przewagi informacyjnej, co może skutkować osiąganiem ponadprzeciętnych stóp zwrotu (Kekäläinen 2004). Inwestorzy, zwłaszcza instytucjonalni o zasięgu globalnym, traktują analizę danych pozafinansowych związanych z ESG przede wszystkim jako analizę dodatkowych czynników ryzyka, a realizowane przez nich badania dotyczą głównie szans i zagrożeń związanych z inwestowaniem w spółki, np. surowcowe oraz z branży energetycznej (The Asset Management Working Group 2007). Najczęściej przedmiotem zainteresowania jest ocena konsekwencji wykluczenia z portfela inwestycji emitentów zaliczanych do kategorii nieodpowiedzialnych, nietransparentnych oraz powiązanie danych związanych z ESG z wartością przedsiębiorstwa1.

Nierówność informacyjna stron kontraktu jest immanentną cechą rynku (zob. Ackerlof 1970, s. 488-500; EC 2013), lecz jej natężenie na rynku kapitałowym zależy w znacznym stopniu od raportowania danych pozafinansowych, ponieważ obowiązujące $\mathrm{w}$ tym zakresie regulacje należy zaliczyć do tzw. miękkich, pozwalających na znaczną dowolność interpretacyjną, umożliwiających stosowanie na zasadzie fakultatywnej, np. comply or explain, często też brak stosowania nie pociąga za sobą realnych sankcji. Badania światowe wykazują, że występuje znacząca luka informacyjna w zakresie danych pozafinansowych ${ }^{2}$. Informacje pozafinansowe uznawane przez menedżerów za istotne (lub bardzo istotne) w procesie podejmowania decyzji są ujawniane w niedostatecznym stopniu, zwłaszcza w zakresie danych dotyczących zwrotu z inwestycji w kapitał ludzki, kosztów rotacji personelu oraz oceny jego produktywności i wewnętrznego rozwoju (rys. 1).

Redukcja asymetrii informacyjnej wymaga rzetelnego okresowego raportowania w zakresie danych pozafinansowych. Według szacunków, obecnie w krajach UE mniej niż 10\% największych przedsiębiorstw ujawnia dane pozafinansowe (EC 2013). Poziom asymetrii informacyjnej różni się na

1 Efekt negatywny włączeń na efektywność i ryzyko portfela inwestycji, zob. Chong, Her, Phillips (2006, s. 406-417); badania wykazujące efekt pozytywny selekcji na ryzyko i efektywność portfela inwestycji, zob. Statman (2006, s. 100-109).

2 Badanie przeprowadzono w 2011 roku wśród tzw. Chef Executive Officers na próbie 1250 przedsiębiorstw w 60 krajach. 
Ry s u n e 1. Luka informacyjna w zakresie danych pozafinansowych spółek

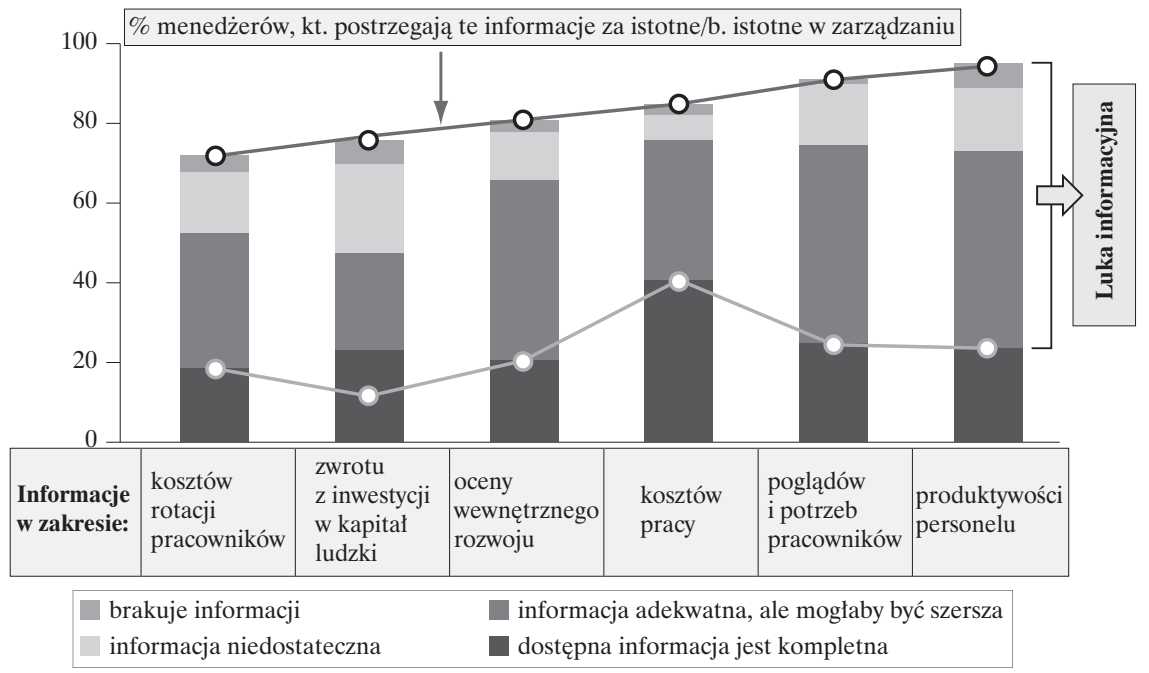

Źródło: Delivering results Growth and value in a volatile world, 15th Annual Global CEO Survey 2012, PricewaterhouseCoopers International (www.pwc.com/ceosurvey).

poszczególnych rynkach UE. W części krajów Unii Europejskiej raportowanie danych pozafinansowych spółek, zwłaszcza dużych, należy nie tylko do tzw. kanonu dobrych praktyk, lecz także jest wymogiem prawnym, jak np. we Francji, gdzie początkowo (od 1977 r.) przedsiębiorstwa zatrudniające powyżej 300 osób zobowiązane są do raportowania tzw. bilansu społecznego (Nouvelles Regulations Economiques art. 116), a od lipca 2010 r. dodatkowo nałożono na wszystkie największe przedsiębiorstwa obowiązek raportowania ESG oraz ich wkładu w zrównoważony rozwój (szerzej: Sroka 2013). Ponadto, na wysoko rozwiniętych rynkach podjęto już wcześniej próbę redukcji luki informacyjnej w zakresie danych pozafinansowych poprzez wdrażanie regulacji rozszerzających obowiązki informacyjne spółek, zalecających ujawnianie danych pozafinansowych, np. w: Wielkiej Brytanii (od 2006 r.) (Department for Environment 2012), Szwecji (od 2007 r.) (Ministry of Enterprise 2007), Hiszpanii (od 2011 r.), Danii (od 2011 r.) (Danish Commerce and Companies Agency 2009). W ramach nowelizacji dyrektyw UE dotyczących rachunkowości (78/660/EWG i 83/349/EWG) Komisja Europejska widzi potrzebę nałożenia powszechnego wymogu raportowania danych pozafinansowych zwłaszcza w przypadku dużych przedsiębiorstw. Obowiązkiem raportowania danych pozafinansowych mają 
być objęte przedsiębiorstwa prowadzące działalność na terenie UE (spó1ki publiczne i nienotowane na rynku publicznym): zatrudniające ponad 500 osób oraz wykazujące sumę bilansową powyżej $20 \mathrm{mln}$ euro (lub obrót netto powyżej $40 \mathrm{mln}$ euro) (EC 2013a). Przedsiębiorstwa te mają sporządzać informację uzupełniającą roczne sprawozdanie finansowe o informacje dotyczące: polityki i wyników postępowania, a także wynikającego z tego ryzyka przedsiębiorstwa związanego z kwestiami: społecznymi, środowiskowymi, zatrudnienia, poszanowania praw człowieka, przeciwdziałania korupcji, jak również praktyk w kwestii różnorodności w organach zarządzających i nadzorczych spółek. Wymóg ten będzie wdrażany na zasadzie comply or explain. Przedsiębiorstwa będą mogły wybrać standard raportowania danych pozafinansowych.

Obecnie w Polsce regulacje prawne (Ustawa z dnia 29 września 1994 r. o rachunkowości, art. 49; Rozporządzenie Ministra Finansów z dnia 19 lutego 2009 r.) również nakładają na przedsiębiorstwa obowiązek ujawniania danych pozafinansowych dotyczących: zatrudnienia, ładu korporacyjnego, środowiska naturalnego, jednak wymóg ten jest traktowany bardzo liberalnie. Raporty dotyczące danych pozafinansowych publikowane są $\mathrm{w}$ zasadzie tylko przez największe spółki, głównie notowane na rynku publicznym. Wciąż brakuje, jak wykazuje nawet pobieżne rozpoznanie wśród zarządzających, jednolitej, kompleksowej oraz - co ważne - systematycznej oceny ryzyka związanego z obszarami pozafinansowymi (tj. ESG) spółek publicznych. $\mathrm{Z}$ jednej strony, wynika to $\mathrm{z}$ wciąż jeszcze, jak wydaje się, niedostatecznej presji $\mathrm{w}$ zakresie uwzględniania danych pozafinansowych, z drugiej zaś z braku konkretnych wytycznych, np. organów nadzorczych.

Egzekwowanie systematycznego, rzetelnego raportowania danych pozafinansowych przyczynia się do wzrostu transparentności, obliczalności działalności spółek, co z kolei przyczynia się w znaczącym stopniu do redukcji asymetrii informacyjnej na rynku kapitałowym, a w konsekwencji, istotnie redukuje błędy prognostyczne w zakresie ryzyko - dochód portfeli inwestycji. Ponadto, większa transparentność przedsiębiorstwa przyczynia się do ograniczenia kontrowersji i konfliktów interesów poszczególnych grup interesariuszy, co często jest przyczyną kryzysów w przedsiębiorstwie i odbija się na jego efektywności i skutkuje wzrostem zmienności kursu emitowanych przez nie instrumentów i szoków cenowych (Becchetti, Cicirettiy i Giovannelli 2012). 


\section{Zakres raportowania danych pozafinansowych przez spółki publiczne notowane na GPW w latach 2012-2013}

Analizy i oceny raportowania danych pozafinansowych w zakresie ESG przez spółki notowane na rynku publicznym w Polsce dokonano z wykorzystaniem metodologii GES Risk Rating 3 . Badaniem objęto całą populację spółek publicznych notowanych na GPW oraz rynku New Connect w analizowanym okresie: łącznie 831 spółek w 2012 roku oraz 853 spółki w 2013 roku. Ocena poziomu raportowania danych pozafinansowych przez spółki publiczne w Polsce dokonywana przez GES Risk Rating opiera się na ocenie transparentności systemów zarządzania w zakresie środowiska, społecznej odpowiedzialności oraz ładu korporacyjnego spółek. Podstawowym źródłem informacji w badaniu są raporty roczne spółek oraz inne ogólnie dostępne dla inwestorów dokumenty i strony internetowe spółek. Dodatkowo, informacje te są uzupełniane danymi ze stron internetowych, np. rządowych, pozarządowych oraz regulatorów, a także artykułów prasowych, publikacji branżowych i serwisów informacyjnych. Ocena ryzyka spółki dokonywana

Rysunek 2. Kryteria oceny raportowania danych pozafinansowych spółek publicznych wg GES Risk Rating

Zarządzanie środowiskiem

Przygotowanie:

- organizacja i procedury

- polityka i programy

- mechanizm weryfikacji zewnętrznej

- raportowanie środowiskowe

- ocena dostawców

Rezultaty:

- gazy cieplarniane

- zużycie energii

- wykorzystanie zasobów wodnych

- racjonalizowanie podróży

służbowych

- rekultywacja i odtwarzanie zasobów

- ocena oddziaływania na środowisko

przyszłych projektów

- odpady niebezpieczne

- emisje do powietrza

- +8 dodatkowych kryteriów

Źródło: GES Risk Rating.
Odpowiedzialność społeczna

\section{Pracownicy:}

- dyskryminacja

- wolność zrzeszania się

- bezpieczeństwo i higiena pracy

- godziny pracy i wynagrodzenie

- +5 dodatkowych kryteriów

Społeczność lokalna:

- przeszkolenie pracowników

ochrony

- korupcja

-+2 dodatkowe kryteria

Dostawcy:

- kodeks postępowania

- system zarządzania i program

- ocena wyników
Lad korporacyjny

\begin{tabular}{l}
\hline Nadzór i kontrola: \\
• komitet audytu, \\
komisja ds. wynagrodzeń, \\
komisja nominacyjna \\
- skład Rady Nadzorczej i jej \\
niezależność \\
- zróżnicowanie Rady Nadzorczej \\
Prawa udziałowców: \\
- równe prawo głosu \\
- przejrzystość struktury \\
własnościowej \\
Przejrzystość i system \\
wynagrodzenia: \\
• wynagrodzenie firm audytorskich \\
- wynagrodzenie prezesa zarządu \\
- raportowanie
\end{tabular}

3 Bazę danych uzyskano od spółki GES Risk Rating, która je zgromadziła i poddała weryfikacji we współpracy ze Stowarzyszeniem Emitentów Giełdowych w ramach cyklicznego projektu „Analiza ESG spółek giełdowych”. 
jest zatem poprzez pryzmat transparentności danych pozafinansowych i procedur stosowanych przez spółki w zakresie: odpowiedzialności społecznej, corporate governance oraz środowiska naturalnego (rys. 2).

Przeprowadzone badania wykazały przede wszystkim, że istnieje znacząca luka informacyjna zwłaszcza w zakresie raportowania zagadnień związanych $\mathrm{z}$ ochroną środowiska oraz obszarem społecznym. Wśród spółek publicznych w sektorach, tj.: technologicznym, telekomunikacyjnym, finansowym, zaledwie od 5 do $15 \%$ emitentów ujawnia informacje dotyczące ochrony środowiska naturalnego oraz odpowiedzialności społecznej (rys. 3). Raportowane przez spółki publiczne dane pozafinansowe dotyczą przede wszystkim ładu korporacyjnego, co niewątpliwie jest związane z polityką GPW w zakresie dobrych praktyk.

Badania wykazały, że dane pozafinansowe raportują przede wszystkim spółki duże, zaliczane do indeksu WIG-20 (rys. 4). Można zaryzykować stwierdzenie, że poziom raportowania danych pozafinansowych jest wprost proporcjonalny do wielkości spółki. Istotną rolę odgrywają tutaj działania w ramach tzw. relacji inwestorskich, realizowane na rynku publicznym przede wszystkim przez dużych emitentów.

Rysunek 3. Luka informacyjna w raportowaniu danych pozafinansowych ESG przez spółki publiczne w Polsce (2012)

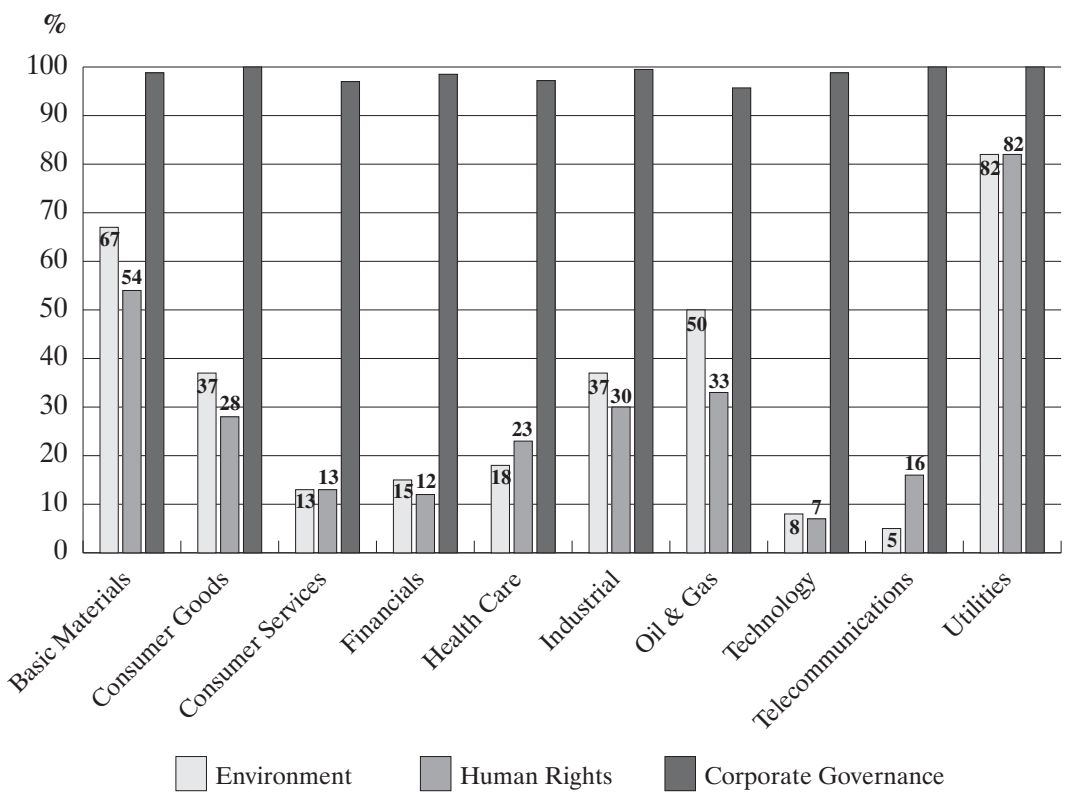

Źródło: opracowanie własne na podstawie danych GES Risk Rating. 
Rysun ek 4. Ocena raportowania danych pozafinansowych w zakresie ESG przez spółki publiczne według indeksów (2012)

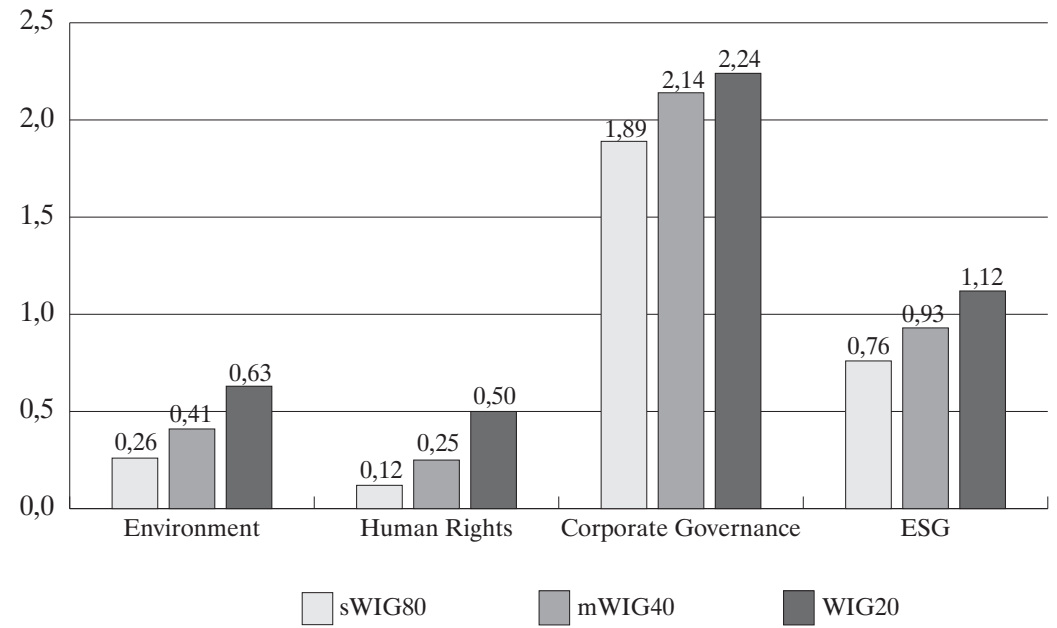

Źródło: obliczenia własne na podstawie danych GES Risk Rating.

Biorąc pod uwagę zakres raportowania ESG oceniany w skali punktowej $^{4}$, należy zauważyć, że ogólny poziom raportowania jest stosunkowo niski (rys. 5). Analiza statystyczna rozkładów ocen zakresu raportowania danych pozafinansowych wykazuje, że spółki najczęściej w zdecydowanej większości nie ujawniają danych dotyczących polityki w zakresie środowiska naturalnego czy społecznej odpowiedzialności lub też nie mają opracowanej polityki zarządzania tym obszarem i ujawniania danych w tym zakresie. Najniższy poziom raportowania dotyczy szeroko pojętych spraw społecznych, pracowniczych i związanych z prawami człowieka (rys. 7). W tym obszarze w zdecydowanej większości spółki publiczne praktycznie nie zajmują stanowiska i nie wypracowują polityki raportowania danych, nie komunikują w zasadzie żadnych

4 Łączny wynik analizy GES Risk Rating jest sumą poszczególnych kryteriów ocenianych w punktach:

- 0 pkt - brak informacji lub całkowite niepowodzenie;

- 0,5 lub 0,33 - wskazówki na istnienie strategii firmy;

- 1 lub 0,67 - rozbudowana polityka firmy;

- 1,5 lub 1 - polityka + program lub polityka + system zarządzania;

- 2 lub 1,33 - polityka + program + system zarządzania;

- 2,5 lub 1,67 - ocena postępu;

- 3 lub 2 - mechanizm zewnętrznej weryfikacji.

Wszystkie kryteria mają przypisaną określoną wartość punktową (zob. Metodologia GES Risk Rating). Pobrano z: www.seg.org.pl. 
Rysu nek 5. Rozkład ocen raportowania danych z zakresu ESG przez spółki publiczne w Polsce w latach 2012-2013

a) 2012

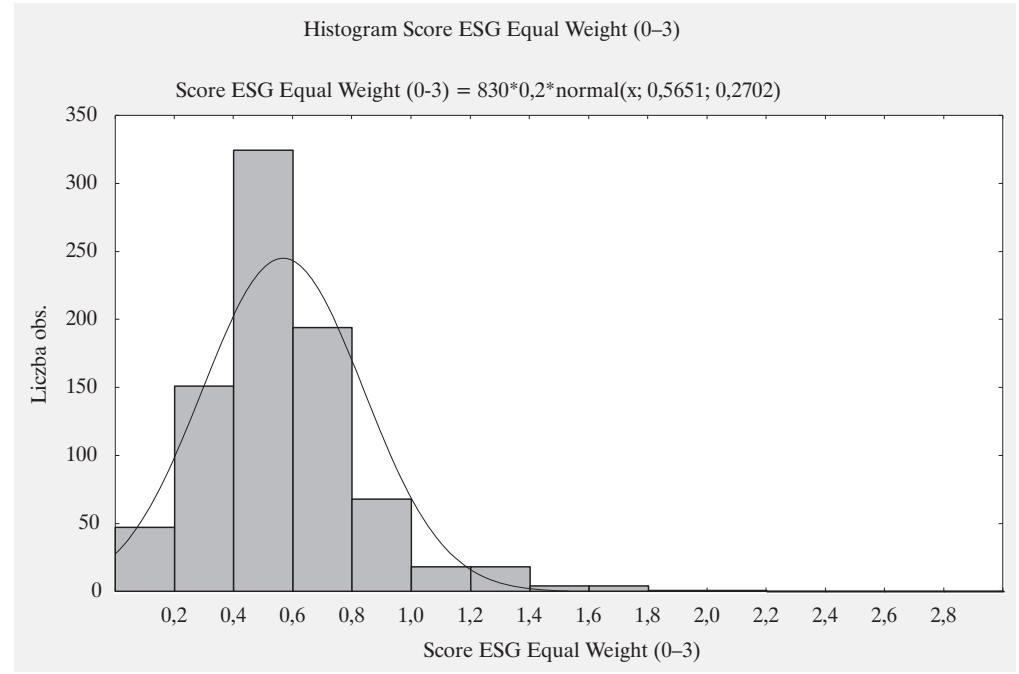

b) 2013

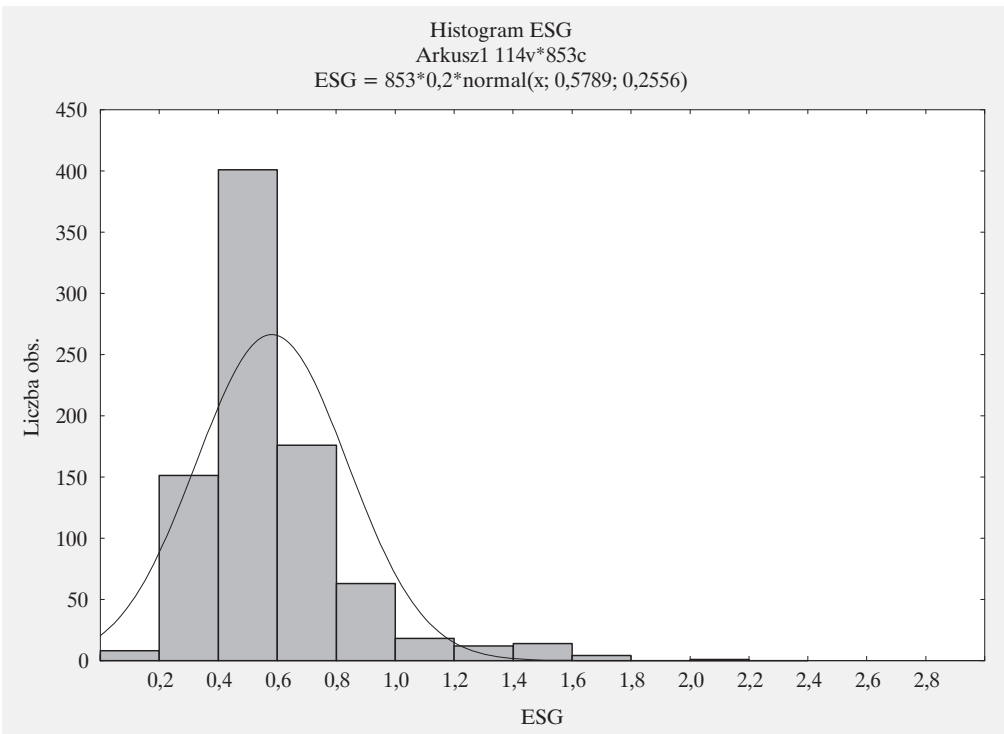

Źródło: obliczenia własne na podstawie danych GES Risk Rating. 
Ry u n e k. Rozkład ocen raportowania w zakresie corporate governance przez spółki publiczne w Polsce w latach 2012-2013

a) 2012

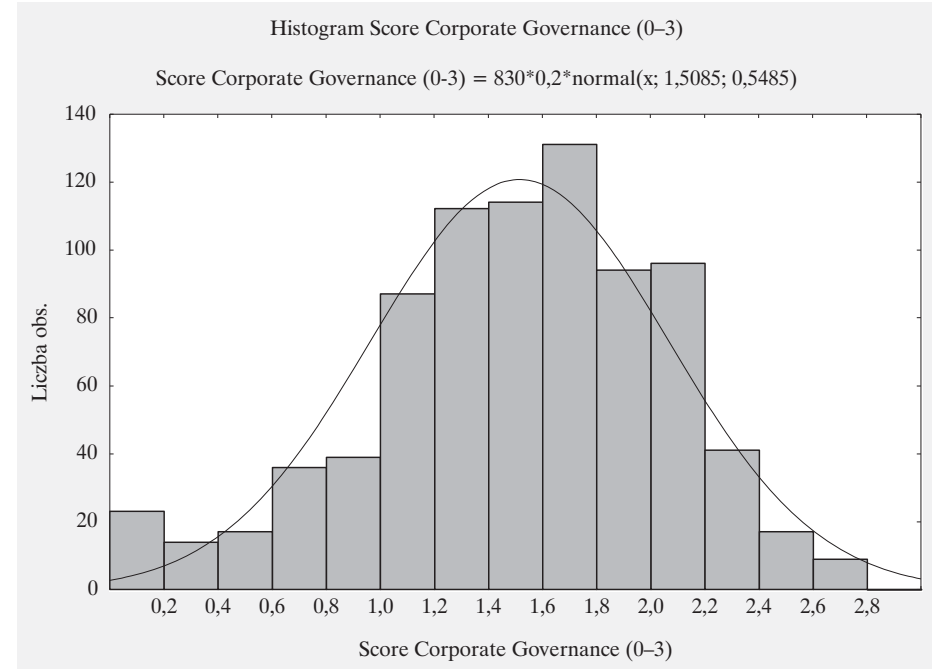

b) 2013

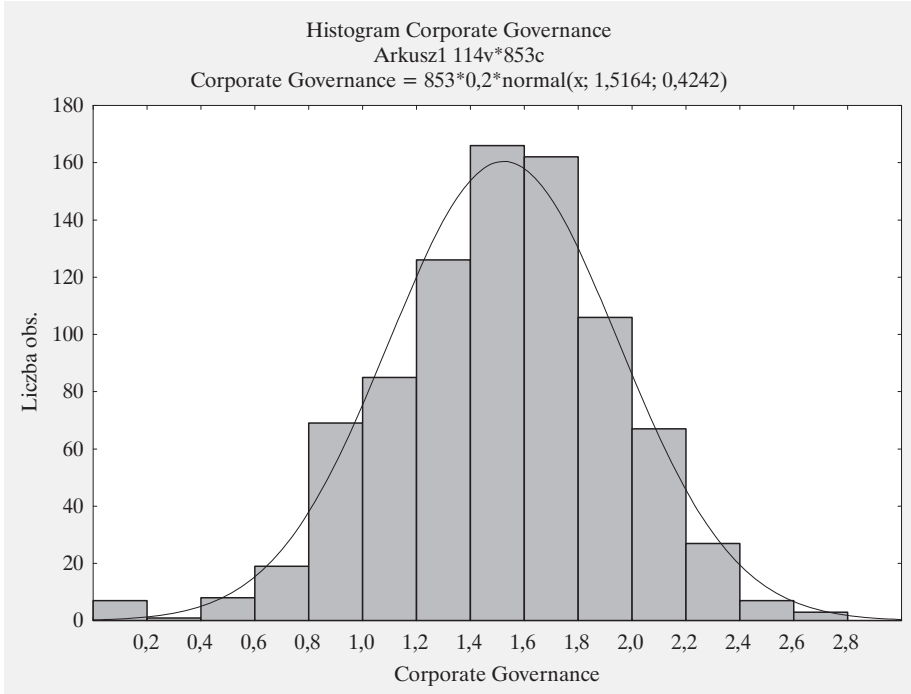

Źródło: obliczenia własne na podstawie danych GES Risk Rating. 
informacji. Najwyższy poziom ujawniania dotyczy informacji związanych z ładem korporacyjnym spółki (rys. 6), co jest wymagane przez GPW, jak już wspomniano, w ramach tzw. dobrych praktyk. Co prawda zakres czasowy badań jest krótki, zaledwie dwuletni, niemniej jednak widoczna jest również istotna statystycznie korelacja pomiędzy poziomem raportowania danych w zakresie społecznej odpowiedzialności i środowiska naturalnego (tab. 1).

Ta b e l a 1. Statystyki opisowe badanej populacji (2013)

\begin{tabular}{|l|c|c|c|c|c|}
\hline \multicolumn{7}{|c|}{ Statystyki opisowe } \\
\hline \multicolumn{1}{|c|}{ obszar oceny } & n obserwacji & średnia & minimum & maksimum & odch. std \\
\hline Enviroment & 853 & 0,13850 & 0,00 & 2,060 & 0,297466 \\
\hline Human Rights & 853 & 0,08175 & 0,00 & 2,025 & 0,227241 \\
\hline Corporate Governance & 853 & 1,51639 & 0,00 & 2,715 & 0,424171 \\
\hline ESG & 853 & 0,57888 & 0,00 & 2,137 & 0,255588 \\
\hline
\end{tabular}

Macierz korelacji:

\begin{tabular}{|l|c|c|c|}
\cline { 2 - 4 } \multicolumn{1}{c|}{} & Enviroment & Human Rights & Corporate Governance \\
\hline Enviroment & 1,000000 & $\mathbf{0 , 7 5 8 3 4 2}$ & $\mathbf{0 , 3 6 9 6 6 3}$ \\
\hline Human Rights & $\mathbf{0 , 7 5 8 3 4 2}$ & 1,000000 & $\mathbf{0 , 3 7 3 8 6 9}$ \\
\hline Corporate Governance & $\mathbf{0 , 3 6 9 6 6 3}$ & $\mathbf{0 , 3 7 3 8 6 9}$ & 1,000000 \\
\hline
\end{tabular}

Uwaga: oznaczone wsp. korelacji są istotne $\mathrm{z} p<, 05000 \mathrm{~N}=853$ (braki danych usuwano przypadkami).

Źródło: opracowanie własne na podstawie danych GES Risk Rating.

Jednocześnie badania wykazały, że, biorąc pod uwagę zróżnicowanie branżowe, najwyższy poziom raportowania wykazują spółki publiczne zaliczane do sektorów: użyteczności, materiałowego oraz petrochemicznego (rys. 9). W ujęciu dynamicznym w relacji do roku poprzedniego można zauważyć pewne zmiany w poziomie raportowania. Jak się wydaje, spółki publiczne dostrzegają powoli potrzebę raportowania danych pozafinansowych w innych obszarach niż corporate governance. W niektórych sektorach zaobserwowano nawet pogorszenie ocen dotyczących raportowania czynników związanych z ładem korporacyjnym, np. w spółkach należących do sektora użyteczności, finansowego oraz telekomunikacyjnego. Niemniej jednak można zaobserwować generalną poprawę parametrów raportowania danych w zakresie ESG w większości analizowanych sektorów. Poprawa ta dotyczyła głównie spółek należących do sektorów: użyteczności, ochrony zdrowia oraz petrochemicznego. Zauważalna jest znacząca poprawa w zakresie raportowania czynników związanych ze środowiskiem naturalnym w spółkach 
Ry s u n e $\mathrm{k}$ 7. Rozkład ocen raportowania danych z zakresu odpowiedzialności społecznej przez spółki publiczne w Polsce w latach 2012-2013

a) 2012

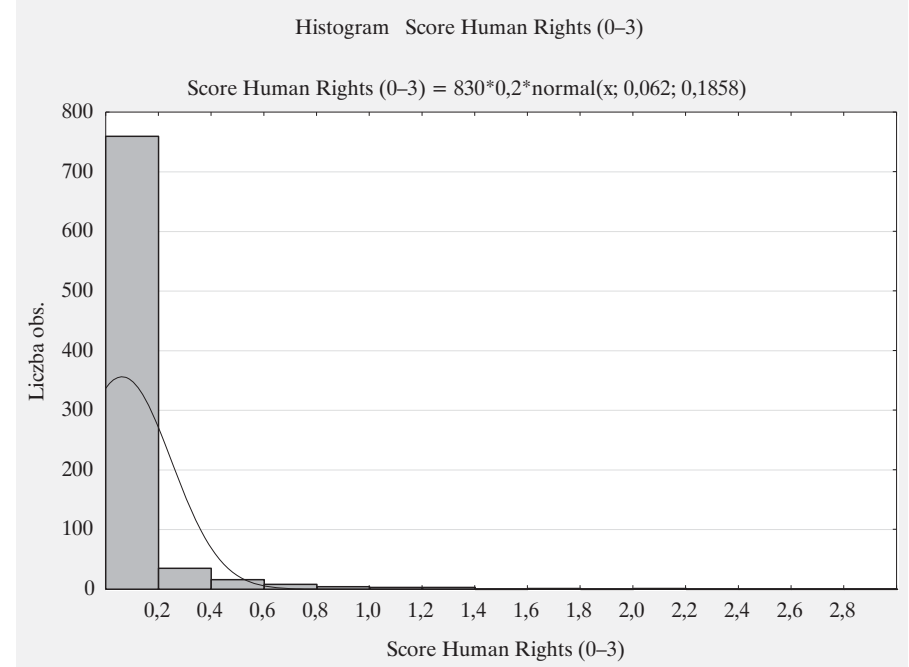

b) 2013

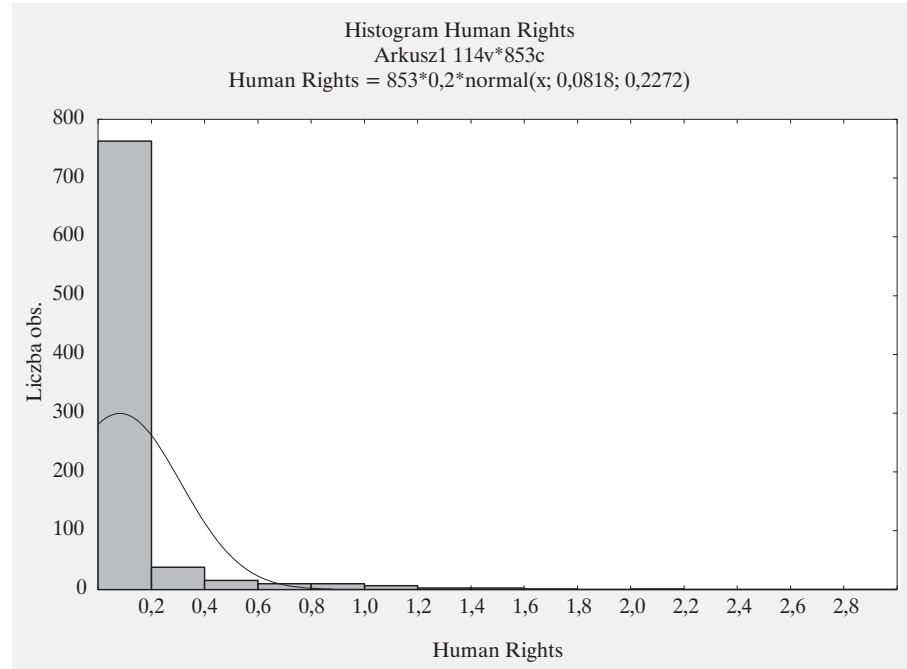

Źródło: obliczenia własne na podstawie danych GES Risk Rating. 
Rys unek 8. Rozkład ocen raportowania danych dotyczących środowiska naturalnego przez spółki publiczne w Polsce w latach 2012-2013

a) 2012

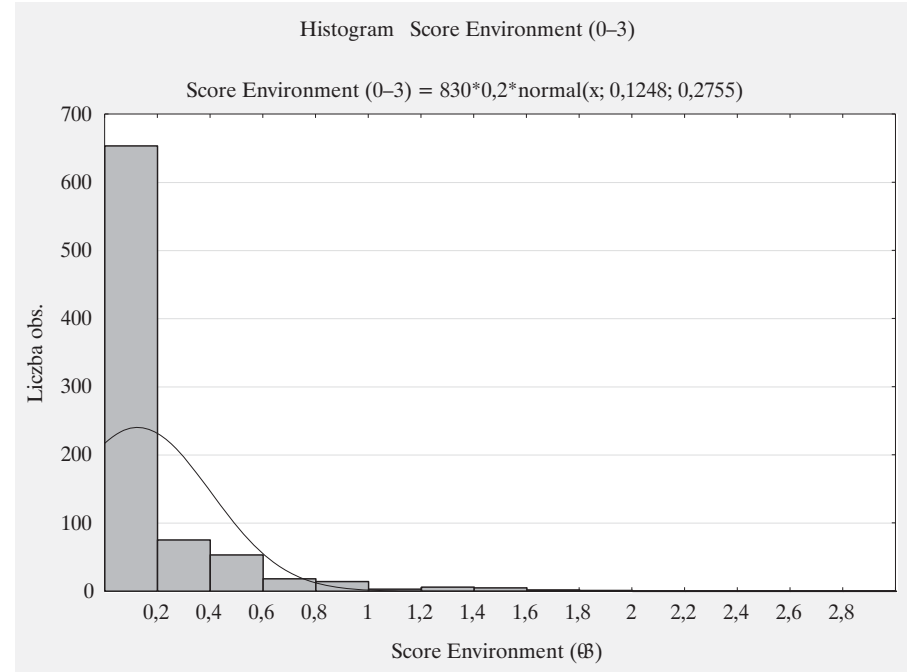

b) 2013

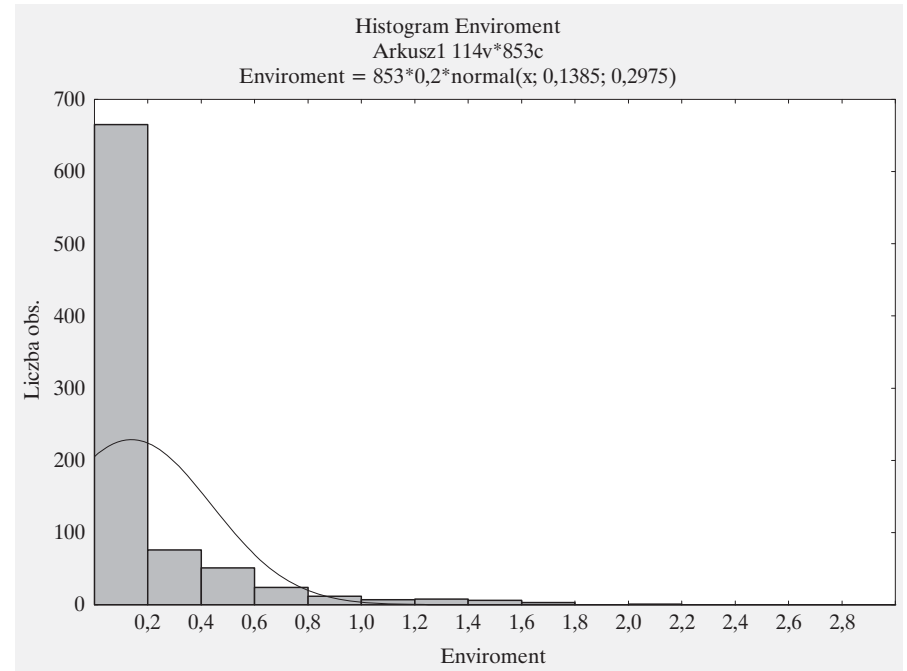

Źródło: obliczenia własne na podstawie danych GES Risk Rating. 
należących do sektorów: finansowego, petrochemicznego i ochrony zdrowia oraz w zakresie czynników związanych z obszarami społecznymi w sektorach: użyteczności, materiałowym i ochrony zdrowia (rys. 9).

Ry s u n e k. Ocena raportowania danych pozafinansowych w zakresie ESG przez spółki publiczne według sektorów (2013)

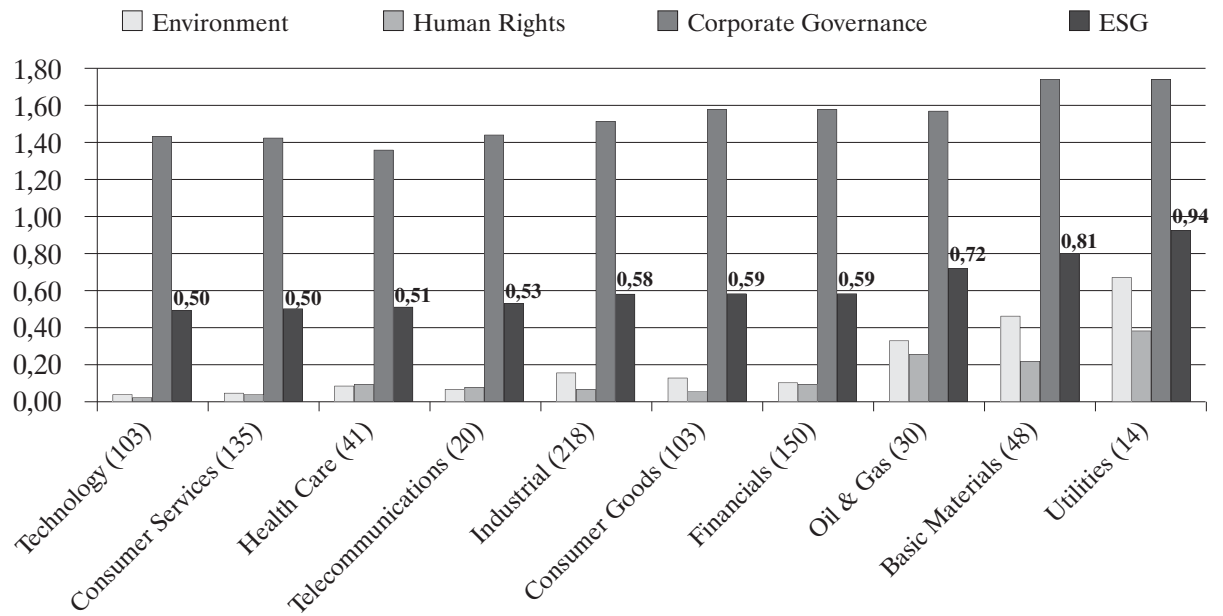

Źródło: opracowanie własne na podstawie danych GES Risk Rating.

Ry u n e 10 . Zmiana ocen raportowania danych pozafinansowych ESG przez spótki publiczne według sektorów ( 2013 w relacji do 2012)

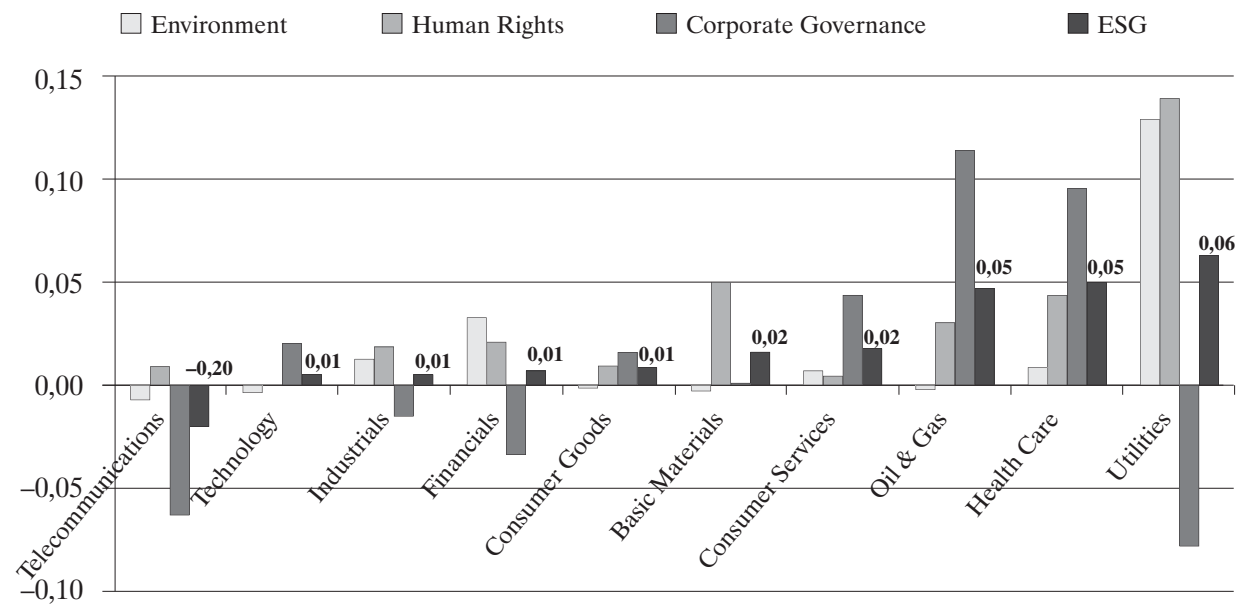

Źródło: opracowanie własne na podstawie danych GES Risk Rating. 


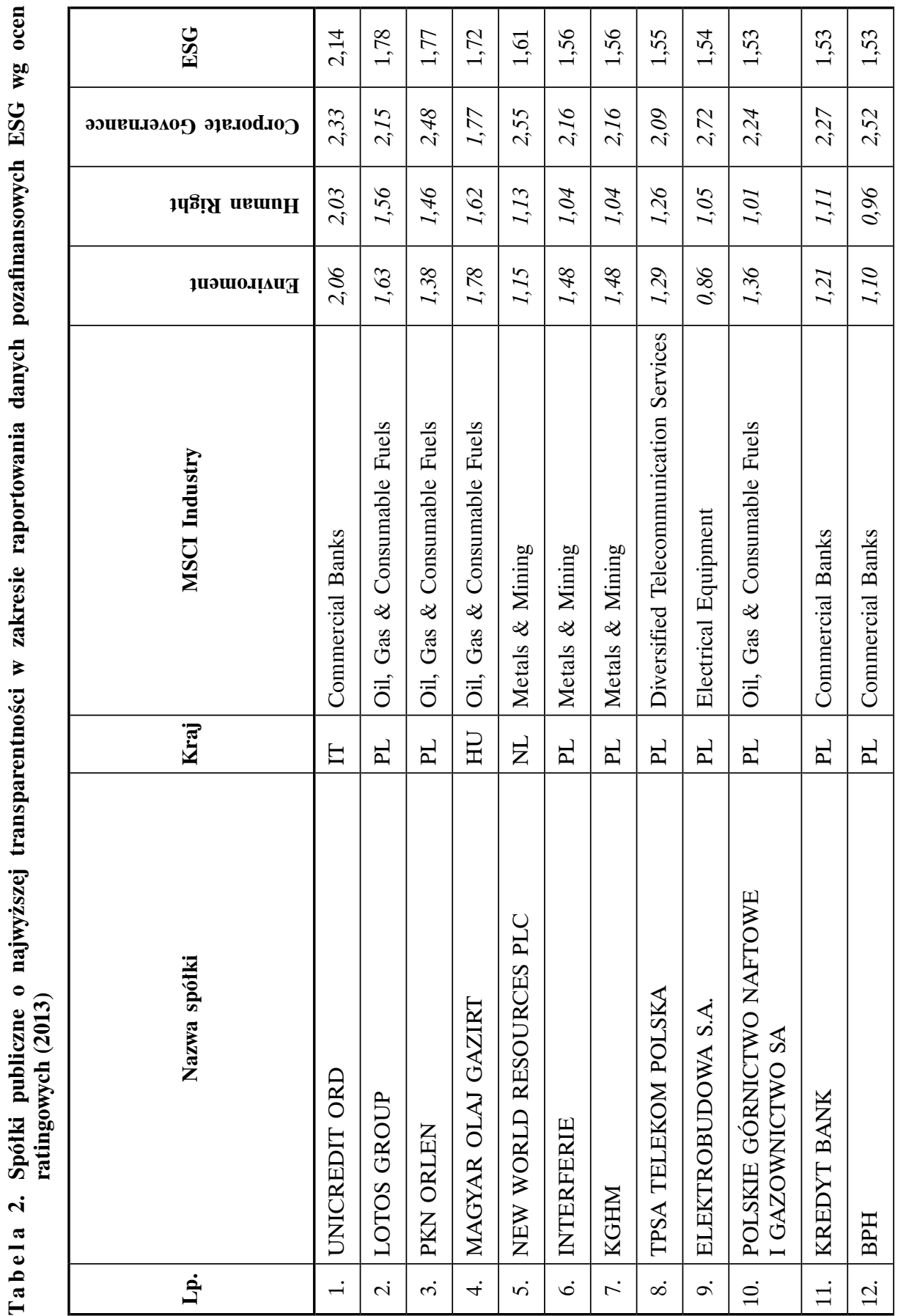




\begin{tabular}{|c|c|c|c|c|c|c|c|c|c|c|c|c|c|c|c|c|c|}
\hline$\sqrt{n}$ & $\stackrel{\circ}{\stackrel{\circ}{\sim}}$ & $\stackrel{\text { fo }}{\stackrel{f}{\sim}}$ & $\stackrel{n}{\stackrel{f}{\sim}}$ & $\underset{\sim}{\stackrel{f}{+}}$ & $\stackrel{\mathscr{f}}{\sim}$ & $\stackrel{\sim}{\underset{f}{\sim}}$ & $\stackrel{\overbrace{}}{-}$ & $\hat{n}$ & $\stackrel{\overbrace{}}{\rightarrow}$ & $\stackrel{?}{\rightarrow}$ & $\stackrel{2}{\sim}$ & $\stackrel{m}{\rightarrow}$ & $\stackrel{m}{\rightarrow}$ & $\stackrel{\infty}{\sim}$ & $\stackrel{\overbrace{}}{\sim}$ & $\stackrel{\overbrace{}}{-}$ & $\underset{\sim}{-}$ \\
\hline$\sqrt{\mathfrak{n}}$ & $\hat{\hat{\sigma}}$ & $\hat{\hat{n}}$ & $\begin{array}{l}\approx \\
\sim\end{array}$ & $\underset{\widetilde{\sigma}}{-}$ & $\hat{\hat{\sigma}}$ & $\underset{v i}{i v}$ & $\stackrel{\infty}{2}$ & $\begin{array}{l}\stackrel{\infty}{\sim} \\
\sim\end{array}$ & $\begin{array}{l}\overrightarrow{2} \\
\vec{v}\end{array}$ & $\begin{array}{l}\stackrel{\sim}{\sim} \\
\sim\end{array}$ & के & $\stackrel{\vec{N}}{\underset{v}{v}}$ & $\begin{array}{l}\stackrel{2}{0} \\
\sim\end{array}$ & $\begin{array}{l}8 \\
i\end{array}$ & $\stackrel{+}{2}$ & $\frac{\infty}{\vec{v}}$ & $\hat{m}$ \\
\hline$\stackrel{8}{2}$ & $\begin{array}{l}8 \\
0\end{array}$ & $\stackrel{2}{2}$ & $\begin{array}{l}7 \\
0\end{array}$ & సે & $\underset{\sim}{\approx}$ & $\stackrel{2}{0}$ & 응 & ㅎ & $\stackrel{2}{2}$ & $\begin{array}{l}0 \\
2 \\
0\end{array}$ & $\hat{\hat{O}}$ & $\stackrel{\infty}{2}$ & $\stackrel{2}{\sigma}$ & $\stackrel{\infty}{2}$ & ర్ & $\hat{N}$ & $\frac{8}{2}$ \\
\hline$\triangleq$ & $\underset{\sim}{\approx}$ & $\stackrel{8}{=}$ & $\stackrel{n}{\sim}$ & $\underset{\sim}{\approx}$ & $\underset{-1}{8}$ & $\triangleq$ & $\pi$ & $\begin{array}{l}n \\
2 \\
0\end{array}$ & $\hat{\imath}$ & $\stackrel{n}{\approx}$ & $\underset{\sim}{\approx}$ & $\stackrel{\infty}{\hat{0}}$ & aे & $\begin{array}{l}\infty \\
\infty \\
0\end{array}$ & $\underset{\sim}{\approx}$ & $\frac{\Omega}{0}$ & $\hat{\hat{N}}$ \\
\hline 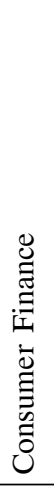 & 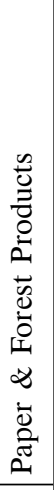 & 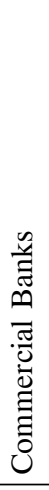 & 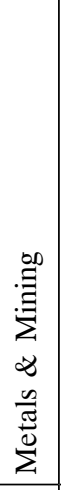 & 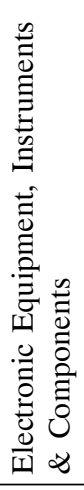 & 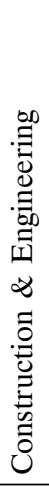 & 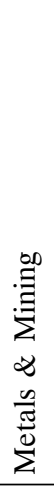 & $\begin{array}{l}\frac{n}{\pi} \\
\frac{\tilde{J}}{\mathbb{E}} \\
\frac{0}{0}\end{array}$ & 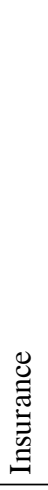 & 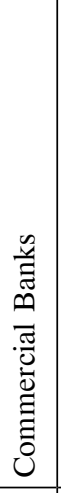 & 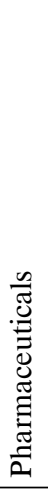 & 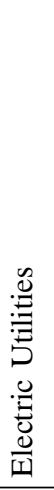 & 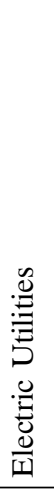 & 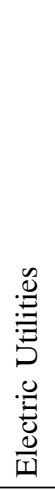 & 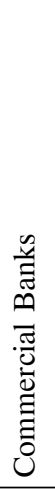 & 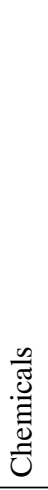 & 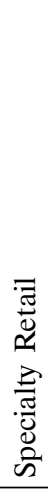 & 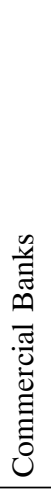 \\
\hline 光 & $\vec{a}$ & $\vec{a}$ & $\vec{a}$ & 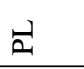 & $\vec{a}$ & 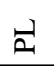 & $\vec{a}$ & $\vec{a}$ & $\vec{a}$ & $\bar{n}$ & $\mathrm{~N}$ & $\vec{a}$ & $\vec{a}$ & $\vec{a}$ & $\vec{a}$ & $\vec{a}$ & $\vec{a}$ \\
\hline 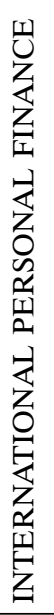 & 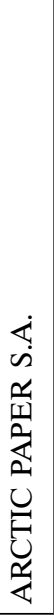 & 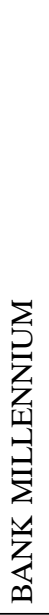 & 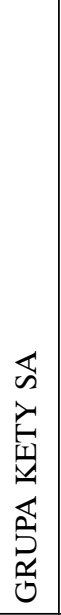 & 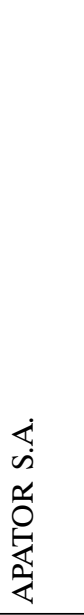 & 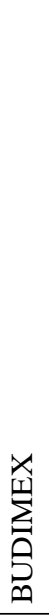 & 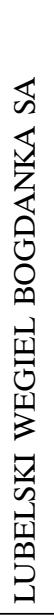 & 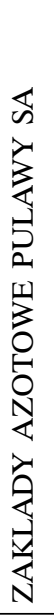 & $\begin{array}{l}\mathbb{\sim} \\
\stackrel{\sim}{N} \\
\stackrel{2}{a}\end{array}$ & 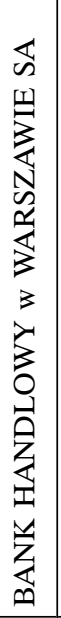 & $\frac{\mathbb{\Delta}}{\mathbb{a}}$ & N & 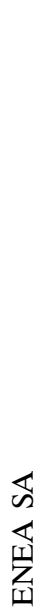 & 崩 & 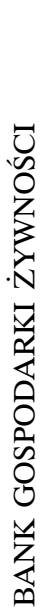 & 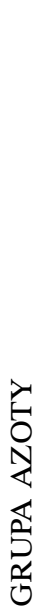 & 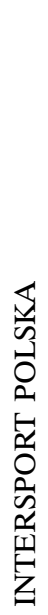 & 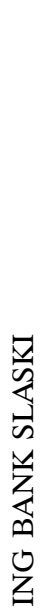 \\
\hline 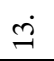 & $\dot{\Xi}$ & $\ddot{n}$ & $\stackrel{\bullet}{\sim}$ & 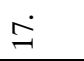 & $\stackrel{\infty}{\sim}$ & $\stackrel{2}{\partial}$ & $\dot{\sim}$ & $\dot{\vec{N}}$ & त் & $\dot{\vec{\lambda}}$ & $\stackrel{\sim}{\sim}$ & $\ddot{a}$ & $\dot{\sim}$ & $\dot{\sim}$ & $\stackrel{\infty}{\sim}$ & $\ddot{\lambda}$ & $\dot{m}$ \\
\hline
\end{tabular}


Badania wykazały, że w Polsce do sektorów cechujących się najwyższym poziomem transparentności w zakresie danych pozafinansowych związanych z ESG należą: finansowy, media i IT. Natomiast, najniższą transparentnością w zakresie raportowania danych pozafinansowych ESG cechują się spółki publiczne należące do sektorów: energetycznego, metalowego oraz produkcji żywności. Do spółek, które cechują się najwyższą transparentnością w zakresie raportowania danych pozafinansowych związanych z ESG należą głównie banki oraz spółki petrochemiczne (tab. 2).

R y s u n e 11 . Ocena raportowania danych pozafinansowych w zakresie ESG przez spółki publiczne według kraju pochodzenia kapitału (2013)

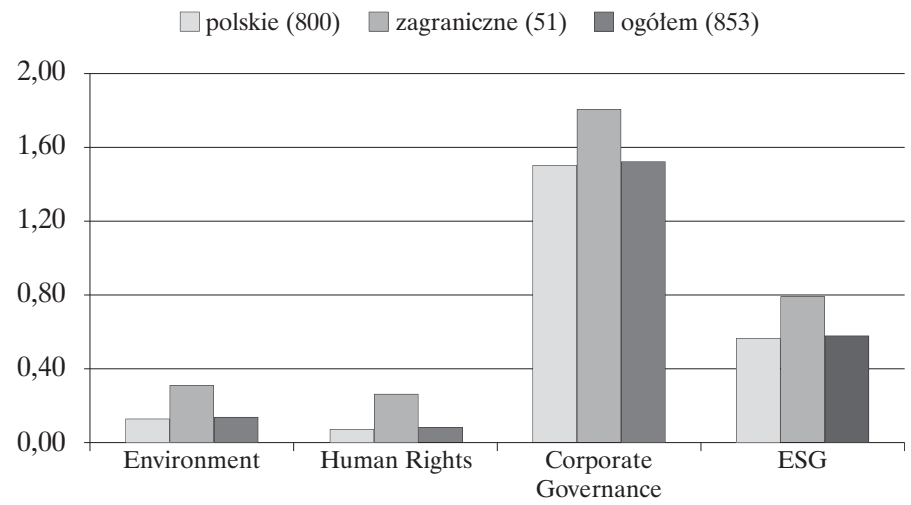

Źródło: opracowanie własne na podstawie danych GES Risk Rating.

Jednocześnie, podobnie zresztą jak w roku 2012, widoczna jest istotna różnica w poziomie raportowania w spółkach polskich i zagranicznych, które cechują się wyższym poziomem raportowania w zakresie każdego z poszczególnych obszarów ESG (rys. 11). Ujawnia się tutaj efekt przenoszenia dobrych praktyk przez emitentów notowanych na zagranicznych bardziej rozwiniętych rynkach kapitałowych, gdzie raportowanie danych pozafinansowych staje się już pewnym standardem. 


\section{Podsumowanie}

Poziom asymetrii informacyjnej na współczesnym rynku kapitałowym zdeterminowany jest w dużej mierze transparentnością emitentów w zakresie raportowania danych pozafinansowych. Wprowadzane na wysoko rozwiniętych rynkach regulacje mają na celu zwiększyć transparentność, a tym samym przyczynić się do większej ich stabilności, zredukować zjawiska szoków cenowych. W części krajów UE raportowanie danych pozafinansowych jest już pewnym standardem. Analiza danych pozafinansowych emitenta pozwala na bardziej adekwatną ocenę ryzyka inwestycyjnego oraz na znacznie bardziej miarodajną wycenę spółki. Przeprowadzone badania dotyczące zakresu raportowania danych pozafinansowych przez spółki publiczne notowane na polskim rynku kapitałowym wykazały, że:

- istnieje znacząca luka informacyjna zwłaszcza w zakresie raportowania zagadnień związanych z ochroną środowiska oraz obszarem społecznym i dotyczącym spraw pracowniczych (najniższy poziom raportowania);

- raportowane przez spółki publiczne dane pozafinansowe dotyczą przede wszystkim ładu korporacyjnego, co jest związane z polityką GPW w zakresie dobrych praktyk;

- dane pozafinansowe raportują przede wszystkim spółki duże, zaliczane do indeksu WIG-20;

- ogólny poziom raportowania danych pozafinansowych związanych z ESG jest niski - spółki najczęściej w zdecydowanej większości nie ujawniają danych dotyczących polityki w zakresie środowiska naturalnego, jak i społecznej odpowiedzialności lub też nie mają opracowanej polityki zarządzania tym obszarem i ujawniania danych w tym zakresie;

- do sektorów cechujących się najwyższym poziomem transparentności w zakresie danych pozafinansowych związanych z ESG na polskim rynku publicznym należą: sektor finansowy, media i IT; natomiast, najniższą transparentnością w zakresie raportowania danych pozafinansowych ESG cechują się spółki publiczne należące do sektorów: energetycznego, metalowego oraz produkcji żywności;

- występuje istotna różnica w poziomie raportowania w spółkach polskich i zagranicznych, które cechują się wyższym poziomie raportowania w zakresie każdego z poszczególnych obszarów ESG.

Zakres czasowy badań jest dość krótki, co nie pozwala na wysnucie bardziej wiążących wniosków. Można jednak zauważyć w ujęciu dynamicznym 
pewne zmiany w poziomie raportowania danych pozafinansowych. Kontynuacja i cykliczność realizowanych badań pozwoli na weryfikację tezy o związku transparentności raportowania danych pozafinansowych ze stopą zwrotu z akcji spółek, czyli identyfikacja ewentualnej „premii rynkowej za transparentność".

\section{Bibliografia}

Ackerlof, G.A. (1970). The Market for 'Lemons': Quality, Uncertainty and the Market Mechanism, Quarterly Journal of Economics, August.

Becchetti, L., Cicirettiy, R. i Giovannelli, A. (2012). Corporate Social Responsibility and Stock Market Efficiency, Working Paper Sustainable Investment Research Platform.

Chong, J., Her, M. i Phillips, G.M. (2006). To sin or not to sin? Now that's the question, Journal of Asset Management, 6(6).

Czerwińska, T. (2013). Ryzyka ESG w spółkach publicznych. W: R. Sroka (red.), Transparentność w obszarze ESG jako element przewagi konkurencyjnej spótki gietdowej. Warszawa: Wyd. Stowarzyszenie Emitentów Giełdowych.

Danish Commerce and Companies Agency (2009). Reporting on corporate social responsibility - an introduction for supervisory and executive boards. Pobrano z: www.CSRgov.dk.

Department for Environment Food and Rural Affairs (2012). Leading businesses to disclose greenhouse gas emissions, June. Pobrano z: www.defra.gov.uk.

EC (2013). Commission moves to enhance business transparency on social and environmental matters, European Commission, IP/13/330, 16/04/2013.

EC (2013a). European Commission proposes ESG disclosure for large companies, April 17. Pobrano z: http://ec.europa.eu/internal_market/accounting/non-financial_reporting/ index_en.htm.

European Asset Owners: SRI Perceptions and Integration Practices (2010). Novethic, December.

Fama, E.F. (1970). Efficient Capital Markets: A Review of Theory and Empirical Work, Journal of Finance, May.

Fama, E.F. (1991). Efficient Capital Markets: II, Journal of Finance, 46(5), 1575-1617, December.

Gompers, P., Ishii, J. i Metrick, A. (2003). Corporate governance and equity prices, The Quarterly Journal of Economics, 118(1).

Kekäläinen S. (2004). Sustainability of privately managed Pension Funds, Final thesis for the Department of Organization and Strategy, University of Tilburg.

Metodologia GES Risk Rating. Pobrano z: www.seg.org.pl.

MG (2013). Raportowanie danych pozafinansowych - przewodnik dla przedsiębiorstw, Ministerstwo Gospodarki, Crido Taxand, Warszawa.

Ministry of Enterprise Energy and Communications (2007). Guidelines for external reporting by state-owned companies 11/2007. Pobrano z: www.regesingen.se.

Ocean Tomo (2011). Intangible Asset Market Value. Pobrano z: http://www.oceantomo.com/ productsandservices/investments/intangible-market-value.

PricewaterhouseCoopers International (2012). Delivering results Growth and value in a volatile world, 15th Annual Global CEO Survey 2012. Pobrano z: www.pwc.com/ceosurvey. 
Rozporządzenie Ministra Finansów z dnia 19 lutego 2009 r. w sprawie informacji bieżących i okresowych przekazywanych przez emitentów papierów wartościowych oraz warunków uznawania za równoważne informacji wymaganych przepisami prawa państwa niebędącego państwem członkowskim (Dz.U. Nr 33, poz. 259).

Sroka R. (2013). Raportowanie społeczne na świecie. W: N. Ćwik (red.), Wspólna odpowiedzialność - rola raportowania spotecznego. Warszawa: Forum Odpowiedzialnego Biznesu.

Stalmach R. (2005). Zarzadzanie firma w interesie akcjonariuszy. Warszawa: Difin.

Statman, M. (2006). Socially responsible indexes: Composition, performance, and tracking error, The Journal of Portfolio Management, 32(3).

Szablewski, A. (2004). Maksymalizacja wartości a społeczna odpowiedzialność przedsiębiorstwa. W: A. Szablewski, R. Tuzimek (red.), Wycena i zarządzanie wartościa firmy. Warszawa: Poltext.

The Asset Management Working Group (2007). Demystifying Responsible Investment Performance. A review of key academic and broker research on ESG factors. A joint report by The Asset Management Working Group. UNEP FI and Mercer, October.

The Principles for Responsible Investment (2007). UNEP Finance Initiative and the UN Global Compact. Pobrano z: www.unpri.org.

Ustawa z dnia 29 września 1994 r. o rachunkowości (Dz.U. z 1994 r., Nr 121, poz. 591). 


\title{
Rozdział IV
}

\author{
AGNIESZKA MAJEWSKA*
}

\section{Katastroficzne instrumenty pochodne - stan rynku i perspektywy rozwoju}

\begin{abstract}
Streszczenie
Zainteresowanie koncepcją przeniesienia ryzyka ubezpieczeniowego na rynek kapitałowy pojawiło się w związku z rosnącymi stratami spowodowanymi zdarzeniami ekstremalnymi w krajach wysoko rozwiniętych. W artykule przedstawiono stan i perspektywy rozwoju rynku katastroficznych instrumentów pochodnych. Analiza rynku z uwagi na dominującą rolę ILWs (Industry Loss Warranties) i obligacji katastroficznych objęła głównie te dwa instrumenty. W odniesieniu do pozostałych produktów brak danych uniemożliwił przeprowadzenie analizy. Wyodrębnione czynniki decydujące o rozwoju ryzyka wskazują, że bezpośrednią determinantą jego wzrostu jest wzrost strat w wyniku zajścia zdarzeń ekstremalnych w krajach wysoko rozwiniętych. Zdarzenia katastroficzne niosące ze sobą rzadkie, aczkolwiek bardzo wysokie straty zmuszają firmy ubezpieczeniowe i reasekuracyjne do poszukiwania alternatywnych źródeł kapitału.
\end{abstract}

Słowa kluczowe: katastroficzne instrumenty pochodne, ILWs, obligacje katastroficzne, zarządzanie ryzykiem katastroficznym.

\begin{abstract}
Abstact
The interest in the concept of the transfer of the insurance risk to the capital market has emerged in connection to increasing losses caused by extreme events in developed countries. This paper presents the status and prospects of development of catastrophe derivatives. Analysis of the market in view of the dominant role of ILWs (Industry Loss Warranties) and cat bonds mainly was limited these two instruments. In relation to the other products, the lack of data had made it impossible to their analyze. Extracted factors of the development of risk indicate that a major determinant of its growth is the increase in losses due to the occurrence of extreme events in developed countries. Catastrophic events bring with them rare but very high losses, thus are forcing insurance companies and reinsurers to seek alternative sources of capital.
\end{abstract}

Keywords: catastrophe derivatives, ILWs, cat bond, catastrophe risk management.

Dr Agnieszka Majewska - Katedra Ubezpieczeń i Rynków Kapitałowych, Wydział Nauk Ekonomicznych i Zarządzania, Uniwersytet Szczeciński; e-mail: magnes@wneiz.pl. 


\section{Wstęp}

Rozwój rynków finansowych wiąże się zarówno z pojawianiem się nowych produktów i instrumentów finansowych, jak i ze zmianami zachodzącymi w zarządzaniu ryzykiem. Katastroficzne instrumenty pochodne wykształciły się w wyniku potrzeb instytucji ubezpieczeniowych, reasekuracyjnych oraz innych firm finansowych zajmujących się działalnością ubezpieczeniową. Rosnący udział strat ubezpieczonych w stratach ogółem będących skutkiem zjawisk katastroficznych ${ }^{1}$ wymaga wypłaty znacznej liczby odszkodowań. Instrumenty pochodne zapewniają instytucjom ubezpieczeniowym dostęp do konkurencyjnego kapitału, który zmniejsza zobowiązania związane z wypłatą odszkodowań oraz umożliwia emisję nowej serii akcji lub pożyczkę kapitału na ustalonych warunkach. Z kolei inwestorom pozwalają zdywersyfikować portfele i uzyskiwać wyższą stopę zwrotu.

Artykuł ma na celu ocenę stanu rozwoju rynku katastroficznych instrumentów pochodnych na świecie wraz ze wskazaniem perspektyw jego rozwoju. Po przedstawianiu motywów powstania i typologii katastroficznych instrumentów pochodnych przeprowadzono analizę rynku z podziałem na instrumenty giełdowe i pozagiełdowe. $\mathrm{Z}$ uwagi na główny udział w rynku instrumentów pozagiełdowych: obligacji katastroficznych oraz ILWs (Industry Loss Warranties) szczegółowo odniesiono się do tych dwóch produktów. W przypadku pozostałych struktur sporadycznie pojawiających się na rynku pozagiełdowym brak danych uniemożliwił przeprowadzenie analizy. Zakres czasowy badania uzależniony był od dostępności danych, stąd w odniesieniu do poszczególnych instrumentów obejmował on różne okresy.

\section{Motywy powstania i typologia katastroficznych instrumentów pochodnych}

Idea wykorzystania instrumentów pochodnych w zarządzaniu ryzykiem katastroficznym narodziła się w branży majątkowej na początku lat dziewięćdziesiątych ubiegłego stulecia. Bezpośrednio przyczyniły sie do tego dwa zdarzenia: Huragan Andrew, który wyrządził szkody o wartości przekraczającej 19,6 mld USD oraz trzęsienie ziemi w Northridge w Kalifornii ze skutkiem

1 W latach 2010-2012 straty ubezpieczone w straty ogółem stanowiły odpowiednio 25, 28 i $41 \%$. 
strat równych 16,3 mld USD². Kumulacja szkód katastroficznych spowodowała konieczność wypłaty znacznej liczby odszkodowań, co przyczyniło się to do niewypłacalności 10 firm ubezpieczeniowych. Rynek ubezpieczeniowy i reasekuracyjny, mając ograniczoną pojemność, nie był w stanie sam pokryć strat, co z kolei pociągnęło za sobą rozwój instrumentów przenoszących ryzyko ubezpieczeniowe na rynek kapitałowy.

Mimo iż ideę wykorzystania instrumentów pochodnych w zarządzaniu ryzykiem katastroficznym przedstawili już na początku lat siedemdziesiątych R. Goshay i L. Sandor (1973, s. 56-66), dopiero 20 lat później, w maju 1990 r. jako pierwsza produkt rynkowy opracowała Chicago Board of Trade (CBOT). Dwa lata później, w grudniu 1992 r., kontrakty futures i opcje zostały wprowadzone do obrotu giełdowego. Jednolicie zaprojektowane umowy ubezpieczenia miały rozwinąć płynny rynek, dzięki któremu ryzyko katastrof można by w łatwy sposób transferować na rynek kapitałowy. Niestety tak się nie stało i ze względu na małe zainteresowanie inwestorów, a co się z tym wiąże niską płynność, trzy lata później zawieszono obrót. Obecnie większość instrumentów występuje w obrocie pozagiełdowym.

Rynek pozagiełdowy katastroficznych instrumentów pochodnych umożliwia uwzględnienie indywidualnych potrzeb instytucji ubezpieczeniowych, reasekuracyjnych oraz innych firm finansowych zajmujących się działalnością ubezpieczeniową. Występująca na rynku giełdowym standaryzacja $\mathrm{z}$ jednej strony gwarantuje przejrzystość produktu, z drugiej - może jednak utrudniać jego dopasowanie do posiadanej ekspozycji na ryzyko. Niewątpliwie zarówno giełdowy, jak i pozagiełdowy rynek katastroficznych instrumentów pochodnych wobec małej pojemności rynku ubezpieczeń oraz wysokich kosztów reasekuracji po zdarzeniach katastroficznych ma na celu umożliwienie branży ubezpieczeniowej zabezpieczenie wyników finansowych.

Należy zwrócić uwagę, że w literaturze katastroficzne instrumenty pochodne czasami określane są jako ubezpieczeniowe instrumenty pochodne. W przekonaniu autora pojęcia te nie powinny być stosowane zamienne. Drugie pojęcie jest znacznie szersze i oprócz wykorzystania instrumentów pochodnych w sekurytyzacji rodzajów ryzyka katastroficznego, obejmuje również sekurytyzację ryzyka życiowego i majątkowego o charakterze nie-

2 Szkody wyrządzone przez te dwie katastrofy łącznie przewyższyły zaistniałe w ciągu poprzednich 12 lat - por. Carayannopoulos, Kovacs i Leadbetter (2003, s. 1-2). Tak znaczne starty wpłynęły na zmianę definicji katastrofy podawana przez Property Claim Service (PCS) - od 1997 roku jest to zdarzenie, które dotyka znaczna liczbę osób i wywołuje uszkodzenie ubezpieczonego mienia o wartości od $25 \mathrm{mln}$ USD (w latach 1982-1996 była to wartość 5 mln USD, a latach 1949-1981 - 1 mln USD). 
katastroficznym. Takie ujęcie zgodne jest z wyróżnieniem przez S. Coxa i R. Schwebacha (1992, s. 628-629) trzech typów ubezpieczeniowych kontraktów terminowych: zdrowotnych, majątkowych i katastroficznych.

W literaturze nie ma jednolitego podziału instrumentów wykorzystywanych w sekurytyzacji ryzyka katastroficznego. Przykładowo Ch.L. Culp i K.J. O'Donnell (2009, s. 447-449) oddzielnie traktują katastroficzne instrumenty pochodne, ILWs (Industry Loss Warranties) i obligacje katastroficzne. Ze względu na cechy i konstrukcje dwa ostatnie produkty nie powinny należeć do oddzielnej kategorii, lecz występować w ramach szerokiej grupy katastroficznych instrumentów pochodnych. Z kolei D. Brach (2003, s. 54-55) w ramach ubezpieczeniowych instrumentów finansowych wyróżnia ubezpieczeniowe instrumenty pochodne oraz ubezpieczeniowe instrumenty hybrydowe (obligacje katastroficzne). Uwzględniając cechy charakterystyczne i konstrukcje poszczególnych instrumentów, zasadny jest podział na sześć głównych grup: ILWs, obligacje katastroficzne, swapy katastroficzne, opcje, kontrakty terminowe, instrumenty hybrydowe. Poza kontraktami futures, które występują wyłącznie w obrocie giełdowym, pozostałe - to głównie instrumenty rynku pozagiełdowego. Przepływy pieniężne związane z powyższymi instrumentami uzależnione są od wystąpienia określonych zdarzeń katastroficznych, a ściślej mówiąc od ich następstw. W pracy, z uwagi na znikomy udział instrumentów giełdowych, ogólnie odniesiono się do obrotu giełdowego, natomiast opisany stan rynku obejmuje dwa dominujące w zarządzaniu ryzykiem katastroficznym instrumenty: ILWs oraz obligacje katastroficzne.

W odniesieniu do walorów bazowych katastroficzne instrumenty pochodne można sklasyfikować jako instrumenty oparte na:

- indeksach branży odnoszących się do strat całego sektora ubezpieczeń, np. indeks PCS (Property Claim Service), GCCI (Guy Carpenter Catastrophe Index);

- indywidualnych stratach podmiotu zabezpieczającego się;

- indeksach parametrycznych (fizycznych) uwzględniających parametry określonej katastrofy, np. dla trzęsień ziemi - skala Richtera; dla huraganów - prędkość wiatru, wielkość ciśnienia w oku cyklonu; dla powodzi - wielkość opadów na danym obszarze;

- modelach straty estymujących straty indywidualne podmiotu zabezpieczającego, opracowywane są przez niezależne firmy, takie jak RMS, AIR, EQECAT.

Istnieją również konstrukcje hybrydowe będące połączeniem różnych struktur odzwierciedlających straty. 


\section{Katastroficzne instrumenty pochodne. Obrót giełdowy}

Wprowadzone w 1992 r. do obrotu giełdowego opcje i kontrakty futures początkowo oparte były na indeksie ISO (Insurance Services Office), który uwzględniał straty katastroficzne zanotowane przez ponad 100 spółek, reprezentujących 23\% branży ubezpieczeniowej nieruchomości (Bruggeman 2010, s. 165). Indeks przestał być wiarygodny, gdy nie odzwierciedlił strat po trzęsieniu ziemi w Northridge w 1994 r. Doprowadziło to do zawieszenia w 1995 r. notowań kontraktów futures, a opcje oparte zostały na indeksie PCS (Property Claim Service $^{3}$ ). Niestety w 2000 r. ze względu na popyt poniżej oczekiwanego oraz małą konkurencyjność wobec innych form zaprzestano notowań również opcji.

Obecnie kontrakty futures i opcje (również binarne) występują w obrocie giełdowym na CME Group ${ }^{4}$. Po ogromnych stratach wywołanych huraganem Katrina w 2005 r. rozpoczęto notowania instrumentów, dla których walorem bazowym jest indeks CHI (CME Hurricane Index). Kalkuluje on potencjalne szkody w odniesieniu do maksymalnej prędkości wiatru $(V)$ i obszaru zasięgu $(R)$ na podstawie publicznie dostępnych danych z National Hurricane Center. Opisywany jest następującą formułą:

$$
C H I=\left(\frac{V}{V_{0}}\right)+\frac{3}{2}\left(\frac{R}{R_{0}}\right) \cdot\left(\frac{V}{V_{0}}\right)^{2},
$$

gdzie:

$V_{0}$ - wartość referencyjna prędkości wiatru równa $74 \mathrm{mil} / \mathrm{h}(119,1 \mathrm{~km} / \mathrm{h})^{5}$; $R_{0}$ - wartość referencyjna zasięgu wiatru równa 60 mil $(96,54 \mathrm{~km})$.

Opracowany został, aby zapewnić szybki i łatwy sposób obliczania szkód huraganów. W zależności od relacji rzeczywistej wartości indeksu do wartości bazowej następuje przepływ kapitału między stronami umowy.

3 Indeks strat katastroficznych liczony od 1949 r. mierzy straty w danym regionie Stanów Zjednoczonych w określonym czasie, 1 pkt odpowiada 100 mln USD strat. Liczony jest dla 9 lokalizacji: całe USA, wschód, północny wschód, południowy wschód, środkowy zachód, zachód, Texas, Floryda, Kalifornia. Z reguły szacowny jest co kwartał, dla niektórych lokalizacji co rok (np. Kalifornia, Teksas). Jest to tzw. okres ekspozycji, po którym następuje okres szacowania strat trwający od 6 do 12 miesięcy. Opcje rozliczane są dopiero po tym okresie.

4 W 2007 roku nastąpiło połączenie Chicago Mercantile Exchange (CME), Chicago Board of Trade (CBOT), New York Mercantile Exchange (NYMEX) i Commodity Exchange (COMEX).

5 Powyżej tej wartości zjawisko silnego wiatru definiowane jest jako huragan. 
W porównaniu do skali Saffira-Simpsona, najczęściej wykorzystywanej do szacowania szkód wyrządzonych wejściem huraganu na ląd, indeks $C H I$ umożliwia pomiar ciaggy, a nie dyskretny. Wartość zero przyjmuje dla prędkości wiatru poniżej wartości referencyjnej i nie jest ograniczony wartością maksymalną. W przypadku, gdy prędkość wiatru i obszar zasięgu odpowiada wartościom referencyjnym $\mathrm{CHI}=2,5$.

Innymi giełdami, na których występują katastroficzne instrumenty pochodne są CATEX (Catastrophe Risk Exchange) i BCOE (Bermuda Commodities Exchange). Obie giełdy nie prowadzą regulowanego handlu, lecz są dostępne wyłącznie dla ich członków.

CATEX utworzona została w $1994 \mathrm{r}$. w celu wymiany ryzyka reasekuracji6. Zorganizowana jest jako giełda internetowa, dla której charakterystyczny jest brak standaryzacji. Stąd jej uczestnicy mogą dowolnie określać wartość kontraktu, specyficzne zagrożenie czy obszary występowania katastrof. Transakcje dostosowane są zatem do indywidualnych potrzeb klientów. Oprócz standardowych produktów istnieje możliwość elastycznego tworzenia struktur hybrydowych, spełniających oczekiwania stron umowy. Transakcje dokonywane za pośrednictwem giełdy obejmują rocznie wartość ponad 4 mld USD. Początkowo głównym produktem były swapy katastroficzne, obejmujące wymianę zobowiązań dotyczących dwóch różnych grup ryzyka katastroficznego. Technicznie porównać to można do wymiany dwóch umów reasekuracyjnych (Himick 1998, s. 62-63). Obecnie stanowią one śladowe ilości transakcji, a większość produktów opiera się na instrumentach z określoną wypłatą świadczenia w przypadku zajścia zdarzenia katastroficznego w zamian za zapłaconą premię (głównie są to opisane poniżej Industry Loss Warranties).

Bermuda Commodities Exchange (BCE) została powołana w 1997 r. jako giełda członkowska, głównie oferująca egzotyczne instrumenty finansowe. Swoim członkom oferuje katastroficzne opcje binarne oparte na indeksie GCCI (Guy Carpenter Catastrophe Index 7 ). Kwota rozliczenia jest ustalona

6 Handel odbywa się za pośrednictwem spółki zależnej CATEX Global Exchange. Spółka wykorzystuje wyspecjalizowane sieci i systemy, których producentem i dostawcą jest CATEX, rozwijający i organizujący platformę oprogramowania. Od 2009 roku funkcjonuje nowy internetowy system transakcyjny Pivot Point 2.0, umożliwiający brokerom, agentom i reasekuratorom zarządzanie ryzykiem. Obecnie system jest wdrażany w dwudziestu krajach (choć nadal większość transakcji dotyczy Stanów Zjednoczonych) w sześciu językach. Zob.: http://www.catex.com; http://www.catexglobalexchange.com.

7 Liczony jest na podstawie danych zbieranych z 39 firm ubezpieczeniowych i wyraża straty w odniesieniu do ubezpieczonej wartości (1 pkt - 0,01\%). Wyznaczany jest co pó1 roku dla sześciu obszarów: całe USA, północny wschód, południowy wschód, środkowy zachód, rejon Gulf, Floryda. 
z góry, a realizacja może nastąpić tylko w określonych terminach do dnia wygaśnięcia opcji (Banks 2004, s. 157).

\section{Industry Loss Warranties (ILWs) ${ }^{8}$}

Pomimo braku polskiego odpowiednika, Industry Loss Warranties można określić jako ubezpieczeniowe warranty straty. Jak podaje E. Michel-Kerjan i F. Morlaye (2008, s. 157) pierwsze ILWs zostały wyemitowane w latach osiemdziesiątych ubiegłego stulecia na pokrycie strat w lotnictwie. Następnie zaczęto je wykorzystywać w celu zabezpieczania ryzyka katastroficznego. Podobnie jak w przypadku pozostałych katastroficznych instrumentów pochodnych, wymagane jest zdefiniowanie zdarzenia katastroficznego, od którego następstw uzależniona jest płatność.

Podmiot nabywający ten instrument otrzymuje prawo do wypłaty określonej kwoty w przypadku, gdy ubezpieczone straty osiągną wcześniej ustaloną wartość progową (może być podana również wartość w „widełkach”). Ich konstrukcja przypomina zatem opcje binarne, dla których charakterystyczna jest stała kwota świadczenia, niezależna od kształtowania się wartości waloru bazowego. Sprzedający za przyjęcie ryzyka otrzymuje określoną premię. $\mathrm{Na}$ rynku istnieje szereg odmian ILWs, w których wypłatę i wartość progową uzależnia się od określonego zjawiska, jego siły, zasięgu, czy czasu trwania (Ishaq 2005, s. 76-77). Podstawowymi walorami bazowymi są następujące indeksy: w Stanach Zjednoczonych - wspomniany wcześniej PCS; w Europie - The Perils Loss Indices ${ }^{9}$. Na obszarach poza Stanami Zjednoczonymi i Europą walory bazowe z powodu braku wskaźników wyznaczane są na podstawie danych dotyczących strat, które publikowane są przez Swiss Re oraz Munich Re NatCat Service.

Wykorzystanie ILWs w zarządzaniu ryzykiem katastroficznym znacząco wzrosło po stratach spowodowanych huraganami, które nawiedziły Stany Zjednoczone w 2005 r. ${ }^{10}$. W 2006 r. w porównaniu z rokiem poprzednim

8 Określane są również jako the original loss warranty (OLW).

9 Dane do indeksu obejmują straty ubezpieczone odnotowane przez firmy ubezpieczeniowe w związku z występującymi wichurami na obszarach: Belgii, Danii, Francji, Niemiec, Irlandii, Luksemburga, Holandii, Norwegii, Szwecji, Szwajcarii, Wielkiej Brytanii, powodziami we Włoszech i Wielkiej Brytanii oraz trzęsieniem ziemi na terenie Włoch.

10 Huragan Katrina (sierpień), Rita (wrzesień) i Wilma (październik) spowodowały łączne straty równe 168 mld USD, z czego ponad połowę (53\%) stanowiły straty ubezpieczone. Ponadto huragan Katrina wpisał się jako katastrofa, dla której odnotowano największe w historii straty ubezpieczone. 
wolumen obrotu wzrósł prawie trzykrotnie (por. rys. 1). Podobna sytuacja miała miejsce po katastrofach naturalnych mających miejsce w latach 2011 i 201211. Wpłynęło to na znaczną liczbę wypłat z ILWs oraz wzrost zainteresowania klientów tą formą sekurytyzacji ryzyka katastroficznego na początku 2012 r. Szacowany przez Willis Re (2012, s. 1) na poziomie od 6,5 do 7,5 mld USD wolumen obrotu okazał się jednak niższy, a w kolejnym roku w porównaniu z poprzednim obniżył się aż o $45 \% 12$.

\section{Ry s u n e k 1. Wolumen obrotu ILWs na świecie w latach 2003-2013}

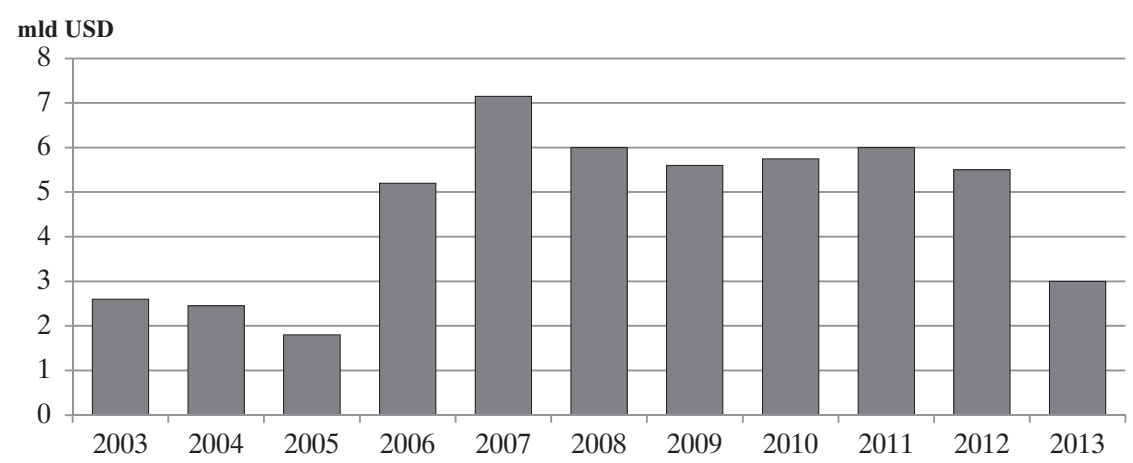

Źródło: opracowanie własne na podstawie danych: Re (2012) oraz informacji ze strony http:// www.trading-risk.com/ilw-volumes-drop-45-in-2013.

Blisko 70\% transakcji z wykorzystaniem ILWs dotyczy terytorium Stanów Zjednoczonych, 18\% Europy, a pozostała przypada na resztę świata (Willis Re 2012, s. 4-5). Wzrostowa tendencja na rynku w latach 2010-2011 spowodowana była występującymi huraganami w Stanach Zjednoczonych i Europie oraz trzęsieniem ziemi i tsunami w Japonii. Należy zaznaczyć, że w zależności od występujących zjawisk katastroficznych ustalane są wartości progów, od których uzależniona jest wypłata. Przykładowo według raportu Willis Re dla Australii, Kanady, Chile i Nowej Zelandii w 2011 roku ustalane były na poziomie 5-10 mld dolarów, podczas gdy obecnie mogą być obniżone do 3 mld dolarów.

11 Wśród 10 największych katastrof według strat ubezpieczonych mających miejsce w latach 1980-2012, trzy zdarzyły się w 2011 r., dwie - w 2012 r. (a osiem w ostatnim dziesięcioleciu). Skutkiem ostatnich pięciu były straty całkowite równe $354 \mathrm{mld}$ USD, a ubezpieczone - 115 mld USD.

12 http://www.trading-risk.com/ilw-volumes-drop-45-in-2013, dostęp dnia 15.12.2013. 


\section{Obligacje katastroficzne ${ }^{13}$}

Obligacje katastroficzne to najbardziej rozpowszechniony instrument zabezpieczający firmy ubezpieczeniowe przed ryzykiem katastroficznym. W latach 2006-2012 średnia wartość emisji wyniosła 15 mld USD ${ }^{14}$ (drugie co do wielkości ILWs miały przeciętną wartość na poziomie 5,6 mld USD). Ponieważ są one zamiennym papierem wartościowym, jako obligacje z wbudowaną opcją, można zaliczyć je do grupy instrumentów pochodnych. Jak podają D. Rode, B. Fischhoff, P. Fischbeck (2000, s. 30) pierwsze tego typu instrumenty zostały wyemitowane w $1996 \mathrm{r}$. na zlecenie firm reasekuracyjnych (AIG, CAT Ltd., ACE Ltd., USAA, CEA, RLI, Hannover Re, St. Paul Re). Było to 8 emisji, z czego połowa została wycofana. Ich wartość wyniosła $243,5 \mathrm{mln}$ dolarów.

Jako instrument pochodny, z którego przepływy powiązane są z możliwością wystąpienia katastrofy, uzależniają wypłatę odsetek i wartości nominalnej od z góry określonej wielkości odniesienia. W przypadku wystąpienia katastrofy, w wyniku której straty przekroczyły ustalony poziom, emitent zostaje zwolniony z części lub całości płatności na rzecz posiadacza obligacji. W roli emitenta nie występuje podmiot zabezpieczający się, inicjujący transakcję (np. firma ubezpieczeniowa czy reasekuracyjna), lecz wybrana spółka celowa (special purpose reinsurer - SPV; special purpose entity - SPE). W jej roli najczęściej występuje firma reasekuracyjna bądź profesjonalni pośrednicy finansowi. Taka struktura jest niezbędna w celu zapewnienia wypłacalności oraz zaakceptowania transferu przez nadzór. Spółka celowa często ze względów podatkowych umiejscowiona jest w rajach podatkowych. Jej działalność ogranicza się wyłącznie do zarządzania wniesionymi środkami a inwestycje mogą obejmować tylko bezpieczne papiery wartościowe. Schemat sekurytyzacji ryzyka za pomocą obligacji katastroficznej przedstawia rysunek 2.

Inwestor nabywając obligację z możliwością braku spłaty, przejmuje ryzyko firmy ubezpieczeniowej w zamian za odpowiednio wyższe oprocentowanie. Zgromadzony przez emitenta kapitał w razie wystąpienia zdarzenia katastroficznego przekazywany jest dla cedującego ryzyko. Umożliwia to instytucjom ubezpieczeniowym wypłatę odszkodowań zaraz po zajściu zdarzenia. Inwestorzy w zamian za przejęte ryzyko otrzymują z obligacji kupony charakteryzujące się wyższą stopą zwrotu. Dodatkowo jako gwarancję przepływów pieniężnych o określonych stopach procentowych spółka celowa

13 Ang. Cut Bonds, „Act of God” Bonds.

14 Wyznaczone na podstawie danych SwissRe. 


\section{Ry s u n e k 2. Sekurytyzacja ryzyka za pomocą obligacji katastroficznej}

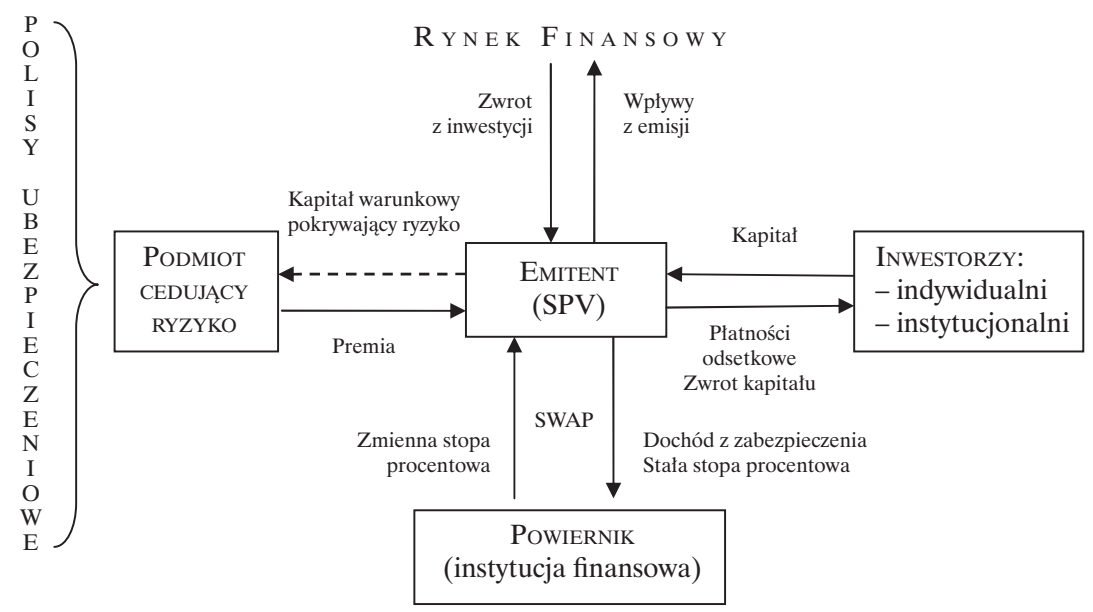

Źródło: opracowanie własne na podstawie: Culp i O’Donnell (2009, s. 448), Bruggeman (2010, s. 155), Carayannopoulos, Kovacs i Leadbetter (2003, s. 5).

może dokonać swapu wymiany stałej stopy (uzyskanej z premii od cedującego ryzyko) na zmienną. Wartość emisji obligacji od początku powstania rynku przedstawia rysunek 3 .

Początkowe lata rynku obligacji katastroficznych charakteryzowały się tendencją wzrostową. Do 2006 r. wartość emisji ogółem rosła średnio z roku na rok o $35 \%\left(\mathrm{R}^{2}=0,98\right)$. Znacznego spadku zainteresowania tą formą transferu ryzyka w kolejnych latach należy upatrywać w ogólnoświatowym kryzysie finansowym, który szczególnie wpłynął na zmniejszenie obrotów na pozagiełdowym rynku instrumentów pochodnych. Na początku kryzysu w 2008 r. emisje ogółem nie odnotowały drastycznego spadku - zaledwie o $10 \%$ - jednak był to wynik $40 \%$ wzrostu wartości emisji trwających. Niestety zauważalna nieufność wobec rynku miała swój wyraz w nowych emisjach, których wartość była prawie trzykrotnie niższa od tych sprzed kryzysu. Podobnie jak w przypadku ILWs, charakterystyczny jest znaczący wzrost emisji w 2006 i 2007 roku (odpowiednio o 57 i $70 \%$ w porównaniu z rokiem poprzednim). Wpływ miały na to wspomniane już huragany, które nawiedziły Stany Zjednoczone w 2005 r. Straty będące wynikiem ich działania stanowily $86 \%$ ogólnych strat odnotowanych w 2005 r. po katastrofach naturalnych. W odniesieniu do strat ubezpieczonych odsetek ten wyniósł aż $96 \%$. Stąd pojawiło się silne zapotrzebowanie na produkty umożliwiające transfer ryzyka i pozyskiwanie niezbędnego kapitału. 
Ry s u n e 3. Wartość emisji obligacji katastroficznych na świecie w latach 1997-2013

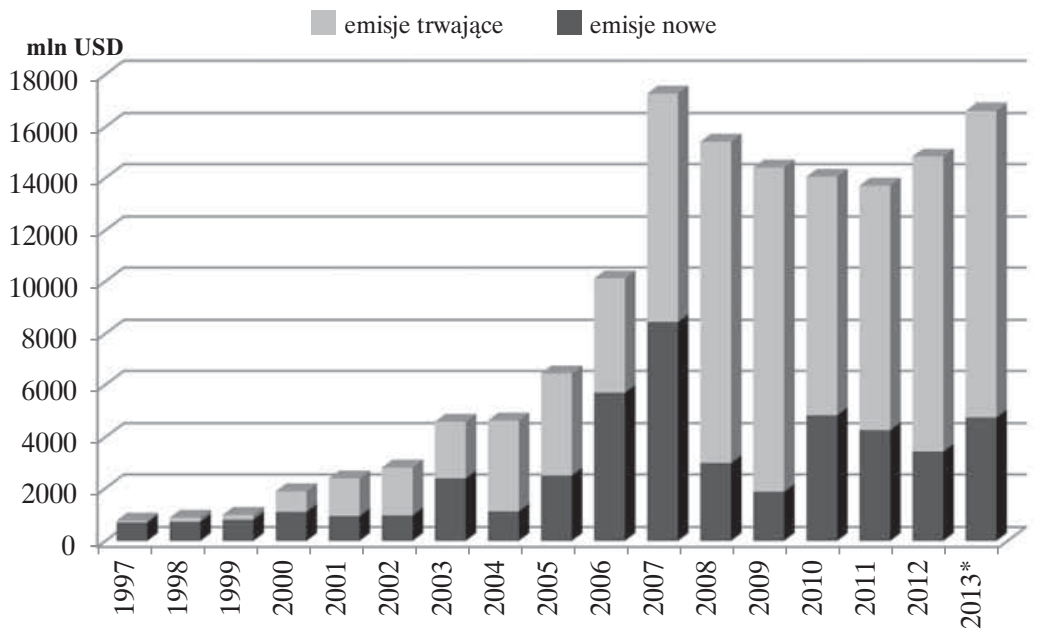

*2013 - dane od stycznia do lipca.

Źródło: opracowanie własne na podstawie danych: Swiss Re (2009; 2012), Guy Carpenter (2013).

Wzrost środków zaangażowanych na rynku obligacji katastroficznych oraz ILWs wiąże się również z rosnącą liczbą zdarzeń katastroficznych. Zasadne jest przyjęcie hipotezy, że powyższe zmienne są dodatnio skorelowane. Wskazują na to współczynniki korelacji wyznaczone na podstawie danych obejmujących lata 2004-2012:

a) liczba zdarzeń katastroficznych - wolumen obrotu ILWs: $r=0,819$ $(\mathrm{p}=0,0035)$

b) liczba zdarzeń katastroficznych - wartość emisji obligacji katastroficznych: $r=0,796(p=0,0051)$.

Po spadkowej tendencji w latach 2007-2011, kolejne dwa lata należy uznać za obiecujące dla rynku obligacji katastroficznych. Szczególnie istotny jest wzrost wartości nowych emisji w 2013 r. Obecne wyniki wskazują, że podmioty chcące transferować ryzyko powoli nabierają przekonania do tych form sekurytyzacji. Wśród zlecających emisje najczęściej występowały firmy: Aetna, Allianz, Assurant, the California Earthquake Authority (CEA), Chubb, Liberty Mutual, Mitsui Sumitomo Insurance (MSI), Munich Re, Swiss Re, Travelers, USAA, Zenkyoren. W odniesieniu do instrumentu bazowego, który w katastroficznych instrumentach pochodnych określany jest jako trigger, można zauważyć zmianę upodobań w badanych latach (por. rys. 4). 
Ry s u n e k. Struktura instrumentu bazowego w obligacjach katastroficznych

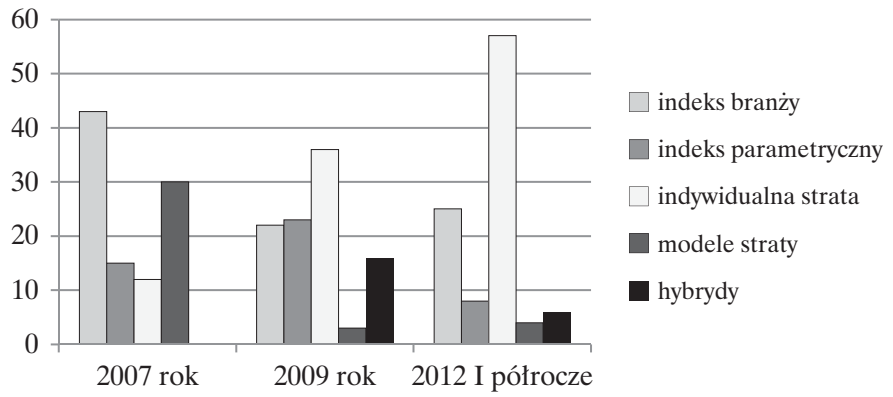

Źródło: opracowanie własne na podstawie danych: Swiss Re (2009; 2012).

W 2009 r. i I półroczu 2012 r. najpopularniejszym walorem wykorzystywanym w konstrukcji obligacji katastroficznych była indywidualna strata podmiotu zabezpieczającego się. Sukcesywnie w badanych latach zyskiwała ona na znaczeniu, a w ostatnim roku jej udział wyniósł blisko 60\%. Drugi w kolejności jest indeks branży, który najwyższą popularność odnotował w 2007 r. W ostatnim, objętym badaniem roku pozostałe trzy parametry (indeks branży, modele straty i hybrydy) miały zbliżony poziom - od 4 do $8 \%$ udziału. W odniesieniu do modeli straty na uwagę zasługuje fakt, że estymacja większości modeli (aż 91\%) dokonywana była przez AIR Worldwide ${ }^{15}$.

Analizując walory bazowe katastroficznych instrumentów pochodnych występujących w obrocie giełdowym i pozagiełdowym, w przypadku pierwszego charakterystyczne jest występowanie indeksów parametrycznych, natomiast na drugim dominują indeksy oparte na stratach. Sytuacja taka wiąże się z charakterem rynków. Obrót giełdowy wymaga standaryzacji, szybkiego rozliczenia i przejrzystości. Indeksy parametryczne wyznaczane na podstawie pomiarów zjawisk pogodowych i geofizycznych zapewniają spełnienie warunków handlu regulowanego. W przypadku obrotu pozagiełdowego warunki umowy mogą być indywidualnie określane przez strony umowy.

Oprócz opisanych powyżej instrumentów w sekurytyzacji ryzyka katastroficznego wykorzystywane są złożone struktury instrumentów pochodnych.

15 AIR Worldwide, założona w 1987 r., jest naukowym liderem i dostawcą oprogramowania do modelowania ryzyka katastroficznego (zarówno naturalnego, jak i terroryzmu). Jako pierwsza opracowała probabilistyczny model katastrofy. Obecnie zajmuje się modelowaniem ryzyka katastroficznego w ponad 90 krajach oraz świadczy usługi doradcze. 
Wśród nich występują opcje na obligacje katastroficzne ${ }^{16}$ czy Catastrophe Equity Put Options (CutEPut) ${ }^{17}$.

\section{Przyszłość rynku katastroficznych instrumentów pochodnych}

Rynek katastroficznych instrumentów pochodnych wykształcił się w wyni$\mathrm{ku}$ potrzeb kapitałowych instytucji ubezpieczeniowych po zaistniałych zjawiskach katastroficznych. Swoim zasięgiem obejmuje głównie Stany Zjednoczone i Europę. Związane jest to przede wszystkim z poziomem rozwoju ekonomicznego oraz stratami notowanymi po katastrofach. Pomimo iż najwyższy odsetek strat wywołanych katastrofami, mającymi miejsce w latach 1980-2012, odnotowano dla Azji - 41\%, zaledwie 14\% odnosiło się do strat ubezpieczonych (występuje tzw. luka ubezpieczeniowa). W Ameryce Północnej odsetki te odpowiednio wyniosły 37 i 64\%, natomiast w Europie 15 i 16\%. Rozwinięty sektor ubezpieczeniowy, wobec wysokich zobowiązań pojawiających się po zdarzeniach ekstremalnych, wymaga narzędzi umożliwiających zabezpieczenia przepływów finansowych.

W krajach rozwiniętych skutki katastrof odczuwane w branży ubezpieczeniowej, potęgowane są bogatą infrastrukturą powstałą w wyniku migracji ludności na tereny wcześniej mało zaludnione i jednocześnie wrażliwe na działanie zjawisk ekstremalnych. Przykładowo blisko 70\% populacji Stanów Zjednoczonych koncentruje się na wybrzeżach (Sandor 2012, s. 241), które są najbardziej narażone na występowanie huraganów. Należy oczekiwać, że wobec rosnącego udziału strat ubezpieczonych w stratach ogółem pożądany będzie dalszy rozwój alternatywnych form reasekuracji. Obecnie dwa najpopularniejsze instrumenty: obligacje katastroficzne i ILW stanowią odpowiednio 5,5 oraz $2 \%$ ogólnej wartości reasekuracji strat katastroficznych.

Wykorzystanie katastroficznych instrumentów pochodnych wymaga zmiany podejścia reasekuratorów i zakładów ubezpieczeń. Konieczne jest sprawne funkcjonowanie działów zarządzania ryzykiem i zatrudnianie

16 Prawo do emisji obligacji po uprzednio ustalonej cenie. Struktura po raz pierwszy użyta przez Allianz Group, gwarantująca transfer ryzyka przy niższych kosztach.

17 Struktura wymyślona przez Aon przeciw spadkom kursów akcji po zdarzeniu katastroficznym, dostępna dla inwestorów instytucjonalnych, zapewniająca kapitał w razie konieczności pokrycia strat. Jest to prawo nabyte od inwestorów przez firmy ubezpieczeniowe do sprzedaży określonej liczy ich akcji po danej cenie w przyszłości, gdy wartość strat katastroficznych osiagnie ustalony poziom (Lee, Lee i Lee 2010, s. 757). 
menedżerów rynków kapitałowych. Zmiany w zakresie prowadzenia działalności ubezpieczeniowej i reasekuracyjnej wymusza również wprowadzenie dyrektywy Solvency II. Podobnie jak Bazylea III, opracowana dla banków, przez konieczność dostosowania wymogów kapitałowych do profilu ryzyka ma ona przyczynić się do efektywnego zarządzania ryzykiem, co z kolei zwiększa poziom harmonizacji w obszarze wypłacalności i zabezpiecza interesy posiadaczy polis. Wymóg pokrycia kosztu kapitału może być spełniony przez szersze wykorzystanie ubezpieczeniowych instrumentów pochodnych (Al-Darwish i in. 2011, s. 50).

W odniesieniu do europejskich zakładów ubezpieczeń i reasekuracji wymagana przez Solvency II (art. 44) konieczność wdrożenia systemu zarządzania ryzykiem powinna sprzyjać zwiększeniu zainteresowania nowymi formami zabezpieczeń ${ }^{18}$. Zgodnie z zasadami Solvency II mogą one stosować sekurytyzację jako skuteczną technikę ograniczania ryzyka. Istotne jest udokumentowanie zasadności i wskazanie efektywności transferu dokonanego za pomocą instrumentów pochodnych. Ponadto konieczne jest uwzględnienie ryzyka niewykonania zobowiązania przez kontrahenta, co jest szczególnie istotne w przypadku produktów pozagiełdowych, które dominują na rynku. Przeszkodą w szerszym wykorzystaniu katastroficznych instrumentów pochodnych może być brak wystarczającej wiedzy oraz niedostateczna liczba wykwalifikowanych pracowników. Przesunięcie terminu rozpoczęcia obowiązywania dyrektywy (wejście w życie planowane jest na rok 2016, a nie jak zakładano początkowo na 2014) wskazuje na brak dostatecznego przygotowania firm ubezpieczeniowych i reasekuracyjnych do wprowadzenia nowych przepisów. Pomimo pozytywnych przesłanek wynikających z Solvency II dla rozwoju alternatywnych form transferu ryzyka, w najbliższych latach nie należy oczekiwać znaczącego wzrostu środków zaangażowanych na rynku katastroficznych instrumentów pochodnych.

Innym elementem przyczyniającym się do rozwoju rynku jest wzrost konkurencji. Rynek faworyzuje dostarczycieli usług o niższym koszcie, potrafiących dostosować się do potrzeb klientów. Bycie konkurencyjnym, przy konieczności spełnienia wymogów kapitałowych, będzie skutkowało poszukiwaniem efektywnych metod transferu i finansowania ryzyka. Dodatkowo zmiana charakteru portfela ubezpieczeniowego (wzrost zarówno wartości, jak i rodzajów ubezpieczanych rodzajów ryzyka) powoduje, że tradycyjna reasekuracja jest niewystarczająca. Ponadto branża ubezpie-

18 Wskazuje również na to raport CEIOPS (Committee of European Insurance and Occupational Pensions Supervisors) - zob. Insurance Linked Securities Report (2009). 
czeniowa w odniesieniu do ryzyka katastroficznego wciąż jest niedokapitalizowana.

Obecnie głównym uczestnikiem rynku katastroficznych instrumentów pochodnych są firmy ubezpieczeniowe i reasekuracyjne, które dzięki niemu mają możliwość sekurytyzacji jednej z najbardziej kapitałochłonnej części działalności. Perspektywy rozwoju wiążą się również z korzyściami dla pozostałych uczestników rynku. Inwestorzy włączając je do swoich portfeli, z uwagi na zazwyczaj słabe skorelowane stóp zwrotu z pozostałymi papierami wartościowymi, mogą dokonywać skutecznej dywersyfikacji, która przyczynia się do osiągania wyższych stóp zwrotu.

\section{Podsumowanie}

Prowadzone rozważania wskazują, że czynnikami decydującymi o rozwoju rynku katastroficznych instrumentów pochodnych jest zwiększanie się liczby zdarzeń katastroficznych oraz rosnący w krajach wysoko rozwiniętych udział strat ubezpieczonych w stratach ogółem. O ile zdarzenia katastroficzne są czynnikiem niezależnym od człowieka, o tyle pozostałe wiążą się z decyzjami podejmowanymi przez ludzi. Wzrost świadomości ubezpieczeniowej przejawiająca się wielkością ubezpieczanych strat wymusza na firmach redystrybucję ryzyka. Dobrze zabezpieczone firmy ubezpieczeniowe powinny być w stanie zapewnić klientom pokrycie oszacowanych szkód. Katastroficzne instrumenty pochodne stanowią alternatywny sposób reasekurowania się. Łączą one rynek ubezpieczeniowy z rynkiem finansowym, zwiększając jego pojemność. Ponadto, będąc w obrocie na wolnym rynku finansowym, mogą przyczynić się do zwiększenia konkurencji rynkowej i zracjonalizowania cen reasekuracji (Sopoćko 2009, s. 17).

Obecnie rynek katastroficznych instrumentów pochodnych głównie ogranicza się do dwóch instrumentów: ILWs i obligacji katastroficznych. Przełomem w jego rozwoju były straty odnotowane w 2005 r. po huraganach, które nawiedziły Stany Zjednoczone. W czasie kryzysu finansowego nieznacznie spadł wolumen transakcji na tym rynku. Obecnie największy wzrost widoczny jest w odniesieniu do emisji obligacji katastroficznych. Rośnie zainteresowanie firm ubezpieczeniowych tymi produktami, które w porównaniu z tradycyjną reasekuracją stanowią tańsze i bardziej elastyczne źródło kapitału. Dla inwestorów jest to z kolei możliwość inwestycji w nowy instrument. W przypadku pozagiełdowych produktów dodatkowym atutem jest możliwość indywidualnego definiowania ekspozycji na ryzyko (zarówno biorcy, jak i dawcy). 


\section{Bibliografia}

Al-Darwish, A., Hafeman, M., Impavido, G., Malcolm Kemp, M. i O’Malley P. (2011). Possible Unintended Consequences of Basel III and Solvency II, IFM Working Paper, Monetary and Capital Markets Department.

Banks, E. (2004). Alternative Risk Transfer. Integrated Risk Management through Insurance, Reinsurance and the Capital Market. New York: John Wiley \& Sons.

Brach, D. (2003). Rynek alternatywnego finansowania ryzyka, Inwestycje finansowe i ubezpieczenia - tendencje światowe a polski rynek. Wrocław: Wydawnictwo AE we Wrocławiu.

Bruggeman, V. (2010). Compensating Catastrophe Victims: A Comparative Law and Economics Approach. Kluver Law International.

Capital Stewardship: Charting the Course To Profitable Growth. Mid-Year Market Overview (2013). Guy Carpenter \&Company, September.

Carayannopoulos, P., Kovacs, P. i Leadbetter D. (2003). Insurance Securitization. Catastrophic Event Exposure and the Role of Insurance Linked Securities in Addressing Risk, Research Paper Series, Institute for Catastrophic Loss Reduction, January.

Cox, S. i Schwebach, R. (1992). Insurance Futures and Hedging Insurance Price Risk, Journal of Risk and Insurance, 59(4).

Culp, Ch.L. i O'Donnell, K.J. (2009). Catastrophe Reinsurance and Risk Capital in the Wake of the Credit Crisis, The Journal of Risk Finance, 10(5).

Dyrektywa Parlamentu Europejskiego i Rady 2009/138/WE z dnia 25 listopada 2009 r. w spawie podejmowania i prowadzenia działalności ubezpieczeniowej i reasekuracyjnej (Wypłacalność II), (Dz. U. L. 335 z 17.12.2009 r.).

Goshay, R.C. i Sandor R.L. (1973). An Inquiry into the Feasibility of a Reinsurance Futures Market, Journal of Business Finance, 5.

Harrington, S.E. (1997). Insurance Derivatives, Tax Policy, and the Future of the Insurance Industry, The Journal of Risk and Insurance, 64(4).

Himick, M. (red.) (1998). Securitized Insurance Risk: Strategic Opportunities for Insurers and Investors. The Glenlake Publishing Company.

Insurance Linked Securities Report. Executive Summary (2009). Committee of European Insurance and Occupational Pensions Supervisors, June.

Ishaq, A. (2005). Reinsuring for Catastrophes through Industry Loss Warranties - A Practical Approach, Casualty Actuarial Society Forum, Spring.

Lee, Ch.F., Lee, A.C. i Lee, J. (red.) (2010). Handbook of Quantitative Finance and Risk Management, Springer.

Michel-Kerjan, E. i Morlaye, F. (2008). Extreme Events, Global Warming, and InsuranceLinked Securities: How to Trigger the "Tipping Point", The Geneva Papers, 33.

Reksa, Ł. (2004). Sekurytyzacja wierzytelności na rynkach międzynarodowych, Bank $i$ Kredyt, luty.

Rode, D., Fischhoff, B. i Fischbeck, P. (2000). Catastrophic Risk and Securities Design, Carnegie Mellon University, Pittsburgh, Working paper.

Sandor, R.L. (2012). Good Derivatives A Story of Financial and Environmental Innovation. New York: John Wiley \& Sons.

Sopoćko, A. (2009). Innowacje sektora ubezpieczeń na rynku kapitałowym, Wiadomości Ubezpieczeniowe, 2.

Swiss Re Capital Markets (2009), Insurance-Linked securities, wrzesień.

Swiss Re Capital Markets (2012), Insurance-Linked securities market update, lipiec.

Willis Re (2012). Q1 2012 ILW update, styczeń. 


\title{
Rozdział V
}

\author{
PATRYCJA CHODNICKA*
}

\section{Determinanty raportowania transakcji podejrzanych przez sektor bankowy}

\begin{abstract}
Streszczenie
W artykule podjęto kwestię ryzyka prania pieniędzy. Wskazano czynniki wpływające na jego wielkość oraz kryteria podziału ryzyka. Ze względu na prowadzenie przez banki działalności transgranicznej przedstawiono również determinanty ryzyka wynikające z takiej aktywności gospodarczej. Pod względem wspomnianych czynników przeanalizowano liczbę raportów przesyłanych przez sektor bankowy w wybranych krajach europejskich, w tym w Polsce. W związku z przeprowadzonymi analizami postawiono hipotezę: Zjawisko raportowania transakcji podejrzanych o pranie pieniędzy przez sektor bankowy uzależnione jest od poziomu rozwoju gospodarczego, stabilności gospodarczej oraz rozwiniętego rynku usług finansowych i jego struktury. Do badania wykorzystano metody statycznej regresji panelowej wraz z niezbędnymi testami.
\end{abstract}

Słowa kluczowe: pranie pieniędzy, sektor bankowy, transakcje podejrzane.

\begin{abstract}
Abstact
In the article was analysed the risk of money laundering. There were presented factors influencing its size and criteria for risk sharing. Due to the conduct cross-border activities by banks are also shown determinants of risk activity. In respect of these factors it was analysed the number of reports sent by the banking sector in selected European countries, including Poland. Due to the fact that studies it was formulated the hypothesis: The phenomenon of reporting suspicious transactions of money laundering in the banking sector is dependent on the level of economic development, economic stability, and developed financial market and its structure. There were used static panel data models with the necessary tests.
\end{abstract}

Keywords: money laundering, banking sector, suspicious transactions.

* Dr Patrycja Chodnicka - Katedra Systemów Finansowych Gospodarki, Zakład Bankowości i Rynków Pieniężnych, Wydział Zarządzania, Uniwersytet Warszawski; e-mail: pchodnicka@wz.uw.edu.pl. 


\section{Wstęp}

Pranie pieniędzy jest zjawiskiem globalnym i łatwo pokonującym granice. Pochodzi od angielskiego zwrotu money laundering i oznacza w sensie largo każdą działalność generowaną przez nielegalną, a niekiedy kryminalną aktywność (Masciandaro 2004). Jej celem jest redukowanie specyficznych kosztów transakcyjnych wywołanych nielegalnym źródłem pochodzenia środków pieniężnych. Jego ekonomiczna funkcja polega na transformowaniu dochodów z nielegalnego źródła pochodzenia lub potencjalnej siły nabywczej w realną siłę nabywczą użyteczną dla konsumpcji, oszczędności czy inwestycji (Masciandaro 2007). Szacuje się, iż zjawisko to może osiągać wartość około 5-7\% światowego PKB (Quirk 1997; Schneider 2007; Schneider i Windischbauer 2008; Schneider 2010).

Naturalnym środowiskiem dla prania pieniędzy w przypadku dużych organizacji są centra finansowe. Co prawda istnieją badania mówiące, że odbywa się ono z daleka od systemów bankowych (Quirk 1997), ale zależy to zarówno od wielkości organizacji, jak i miejsca dokonywania operacji. W związku $\mathrm{z}$ narażeniem sektora finansowego na ryzyko prania pieniędzy wdrażane są liczne regulacje mające na celu przeciwdziałanie temu zjawisku.

Zjawisko raportowania transakcji podejrzanych o pranie pieniędzy przez sektor bankowy do krajowych jednostek analityki finansowej jest bardzo zróżnicowane. Uzależnione jest od kilku czynników. Dyrektywa 2005/60 WE Parlamentu Europejskiego i Rady z dnia 26 października 2005 roku w sprawie przeciwdziałania korzystaniu $\mathrm{z}$ systemu finansowego $\mathrm{w}$ celu prania pieniędzy oraz finansowania terroryzmu oraz przepisy krajowe ryzyko prania pieniędzy dzielą na cztery kategorie: przedmiotowe, podmiotowe, geograficzne i behawioralne. Przy nawiązywaniu stosunków gospodarczych w ramach bankowości, w szczególności korespondencyjnej zwraca się szczególną uwagę na ryzyko geograficzne.

Zweryfikowano hipotezę o wpływie poziomu rozwoju gospodarczego, stabilności gospodarczej oraz rozwiniętego rynku usług finansowych i jego struktury na raportowanie transakcji podejrzanych przy wykorzystaniu modelów regresji panelowej. Do badania wykorzystano dane dotyczące 47 krajów europejskich dla lat 2001-2010. Informacje pozyskano z raportów krajowych jednostek analityki finansowej oraz baz danych Banku Światowego, Transparency International, Komitetu Bazylejskiego do spraw Nadzoru Bankowego oraz Heritage Fundation. 


\section{Przegląd literatury}

W krajach, które zaimplementowały przepisy dotyczące zapobiegania praniu pieniędzy istnieje obowiązek rejestrowania transakcji ponadprogowych oraz natychmiastowego zgłaszania transakcji podejrzanych organom nadzoru, tak zwanym krajowym jednostkom analityki finansowej. W rzeczywistości przepisy te odnoszą się głównie do banków, one to bowiem monitorują oraz raportują znaczną większość wspomnianych transakcji (w zależności od kraju od 60 do $99 \%$ wszystkich raportowanych transakcji).

Dotychczas ukształtowane zostały dwa podejścia do problemu ryzyka prania pieniędzy. Pierwsze z nich oparte jest na regułach (rule based approach). $\mathrm{Na}$ jego potrzeby formułowany jest katalog najbardziej prawdopodobnych sytuacji, w których może dochodzić do prania pieniędzy. Jeżeli spełnione są wszystkie warunki, wówczas instytucja ma obowiązek raportowania i wszczyna się proces oceny transakcji pod kątem jej nielegalności (Hannan i Ross 2007). Podstawową wadą tego podejścia okazuje się możliwość zaadaptowania wskazanych technik przez podmioty zajmujące się opisywaną działalnością, a w konsekwencji nieskuteczność przeciwdziałania temu zjawisku. Ponadto obszerny katalog podejrzanych działań skutkuje dostarczaniem znacznej liczby zbędnych informacji dotyczących legalizacji dochodów pochodzących z czarnej gospodarki (Reuter i Truman 2004), czego efektem jest niska wykrywalność transakcji.

Drugie podejście w przeciwdziałaniu praniu pieniędzy oparte jest na ryzyku (risk based approach). Zostało ono wdrożone w krajach Unii Europejskiej jako wynik Dyrektywy 2005/60 WE Parlamentu Europejskiego i Rady z dnia 26 października 2005 roku w sprawie przeciwdziałania korzystaniu $\mathrm{z}$ systemu finansowego w celu prania pieniędzy oraz finansowania terroryzmu. Powodem tych zmian okazały się innowacje w zakresie kryminalnych rozwiązań legalizacji analizowanego zjawiska, prowadzące do trudności administracyjno-prawnych w celu ustalenia kryteriów ex-ante. W związku z tym zarządzanie ryzykiem prania pieniędzy ograniczono do badania zachowań poszczególnych klientów. Wprowadza ono obowiązek udowodnienia swojego stanowiska w zakresie podejrzenia prania pieniędzy przed regulatorem lub organami prawnymi (Draghi 2007; Hannan i Ross 2007). Banki nie zawsze są gotowe do podejmowania takiego zaangażowania. Duże podmioty z obszerną bazą klientów i znaczącymi aktywami charakteryzują się niską tendencją do ryzyka i mogą odmówić realizacji transakcji przez klienta z błahego powodu (Butler i Ribstein 2006, s. 58). Mniejsze banki, cechujące się skromniejszą bazą klientów, narażone na wysoką konkurencję, mogą być 
skłonne do realizacji operacji zmierzających do legalizacji dochodów pochodzących z działalności niezgodnej z literą prawa, w szczególności, gdy przeprowadzane zlecenia opiewające na znaczne kwoty są wysokodochodowe dla banku oraz wówczas, gdy próby zwalczania prania pieniędzy okazują się bardzo kosztochłonne (Geiger i Wuensch 2006). Innym rozwiązaniem stosowanym przez banki jest pozostawianie decyzji krajowym jednostkom analityki finansowej. Wspomniana strategia realizowana jest przez przekazywanie raportów o transakcjach podejrzanych, a następnie oczekiwanie na podjęcie decyzji przez organy nadzoru. W przedstawionym przypadku bank minimalizuje ryzyko ex-post (Unger i van Waarden 2009; Pellegrina i Masciandro 2009). Efektem jest przesyłanie bardzo dużej ilości informacji powodującej trudności w interpretacji. Problem ten w literaturze jest opisany przez koncepcję crying wolf i informacyjną krzywą Laffera (Reuter i Truman 2004; Takats 2007; Takats 2008). Badania przeprowadzone w Stanach Zjednoczonych (Takats 2007; Takats 2008; Ailofi i Pieth 2003), Włoszech (Costa 2008), Wielkiej Brytanii (Gold i Levi 1994) dowodzą ich prawdziwości.

Dotychczasowe badania odnosity się do analizy trzech grup determinantów mogących wpływać na liczbę raportowanych transakcji podejrzanych o pranie pieniędzy. Jednocześnie brak było w nich jednoznacznego kierunku wpływu, a sama analiza oparta była na modelach teoretycznych. Najczęściej badano, jak poziom rozwoju gospodarczego mierzonego poziomem PKB per capita wpływa na liczbę transakcji zgłaszanych przez sektor bankowy (Mitchell 2002; Veiga, de Andrade i Oliveira 2006; Argentiero, Bagella i Busato 2008, 2009; Masciandaro 2004; Grzywacz 2010; Herdman 1995). Weryfikowano, jak poziom korupcji oddziałuje na analizowane zjawisko (Mauro 1995, 1997; Leite i Weidmann 1999; Alesina i Weder 2002; Fredriksson, Multhukumara i Damania 2003; Barro 1990; Levine Renelt 1991; Salifu 2008; Bartlett 2002; Bungard 2001) oraz czy same rozmiary sektora finansowego są istotne dla liczby przesyłanych transakcji podejrzanych przez banki (Reuter i Truman 2004; Veiga, de Andrade i Oliveira 2006; Quirk 1997, Masciandaro 2004; Chaikin 2009; 2009a).

\section{Sformułowanie modelu oraz prezentacja wyników}

Do modelu wykorzystano obserwacje dla 47 krajów europejskich ${ }^{1}$ w latach 2001-2010. Zmienną zależną wykorzystaną w modelu jest liczba

1 Albania, Andora, Armenia, Austria, Belgia, Białoruś, Bośnia i Hercegowina, Bułgaria, Chorwacja, Cypr, Czechy, Czarnogóra, Dania, Estonia, Finlandia, Francja, Grecja, Gruzja, Hiszpania, Holandia, Irlandia, Islandia, Lichtenstein, Litwa, Luksemburg, Łotwa, 
raportów dotyczących transakcji podejrzanych o pranie pieniędzy, przesyłanych przez sektor bankowy do krajowych jednostek analityki finansowej (zmienna reports). Ze względu na duże zróżnicowanie danych postanowiono wykorzystać opisaną zmienną w postaci zlogarytmowanej. Listę zmiennych niezależnych przedstawiono w tabeli 1.

Ta be l a 1. Charakterystyka zmiennych objaśnianych wykorzystanych w modelu

\begin{tabular}{|c|c|c|}
\hline Lp. & Zmienna & Skrót \\
\hline \multicolumn{3}{|c|}{ Poziom rozwoju gospodarczego } \\
\hline 1. & Produkt krajowy brutto w przeliczeniu na mieszkańca & gdp \\
\hline \multicolumn{3}{|c|}{ Poziom stabilności gospodarczej } \\
\hline 2. & Indeks wolności gospodarczej & free \\
\hline 3. & Indeks korupcji & cor \\
\hline 4. & Indeks AML zaproponowany przez Komitet Bazylejski & $a m l$ \\
\hline 5. & Indeks atrakcyjności kraju B. Unger i J. Walkera & unger \\
\hline \multicolumn{3}{|c|}{ Skala rynku finansowego } \\
\hline 6. & Wskaźnik płynnych zobowiązań do PKB & liquid \\
\hline 7. & $\begin{array}{l}\text { Wskaźnik kredytów udzielanych przez banki depozytowe i instytucje } \\
\text { finansowe do PKB }\end{array}$ & all \\
\hline 8. & Wskaźnik depozytów instytucji finansowych do PKB & financial \\
\hline \multicolumn{3}{|c|}{ Skala sektora bankowego } \\
\hline 9. & Wskaźnik depozytów banków komercyjnych do PKB & deposit \\
\hline 10. & Wskaźnik prywatnych kredytów udzielanych przez banki do PKB & credit \\
\hline 11. & Wskaźnik wartości aktywów banku centralnego do PKB & central \\
\hline 12. & Wskaźnik aktywów banków depozytowo-kredytowych do PKB & assets \\
\hline 13. & Wskaźnik aktywów banków depozytowych do aktywów sektora bankowego & bankassets \\
\hline \multicolumn{3}{|c|}{ Efektywność sektora bankowego } \\
\hline 14. & Marża odsetkowa netto & net \\
\hline 15. & Wskaźnik kosztów ogólnych & overhead \\
\hline 16. & Wskaźnik kredytów do depozytów & creditdep \\
\hline 17. & Wskaźnik kosztów ogólnych do przychodów brutto & costin \\
\hline
\end{tabular}

Macedonia, Malta, Mołdawia, Monako, Niemcy, Norwegia, Polska, Portugalia, Rosja, Rumunia, San Marino, Serbia, Słowacja, Słowenia, Szwajcaria, Szwecja, Turcja, Ukraina, Węgry, Wielka Brytania, Włochy, Stany Zjednoczone. 


\begin{tabular}{|l|l|l|}
\hline Lp. & \multicolumn{1}{|c|}{ Zmienna } & \multicolumn{1}{|c|}{ Skrót } \\
\hline Struktura sektora bankowego & concen \\
\hline 18. & Wskaźnik koncentracji & roa \\
\hline Zyskowność sektora bankowego & roe \\
\hline 19. & ROA & \multicolumn{2}{l|}{} \\
\hline 20. & ROE & zscore \\
\hline Stabilność sektora bankowego & offshore \\
\hline 21. & Wskaźnik - z & remittance \\
\hline Globalizacja sektora bankowego & loans \\
\hline 22. & Wskaźnik depozytów banków z krajów offshore do depozytów & solvency \\
\hline 23. & Wskaźnik przepływów środków pieniężnych do PKB & \\
\hline 24. & Wskaźnik zagranicznych pożyczek od banków nierezydentów do PKB & \\
\hline Ryzyko sektora bankowego & Współczynnik wypłacalności & \\
\hline 25. &
\end{tabular}

Źródło: opracowanie własne.

Ze względu połączenie wymiaru czasowego i przekrojowego otrzymano dane panelowe (panel data). $\mathrm{Z}$ powodu charakteru danych postanowiono wykorzystać do badania modele statyczne. W związku z występowaniem zmiennej stałej w czasie zastosowano model panelowy z dekompozycją składnika losowego przy wykorzystaniu uogólnionej metody najmniejszych kwadratów. Model przyjmuje następującą postać:

$\ln$ reports $_{i, t}=\beta_{0}+\beta_{1} \ln$ gdp $_{i, t}+\beta_{2} \ln$ bankassets $_{i, t}+\beta_{3} \ln$ liquid $_{i, t}+$

$+\beta_{4} \ln$ central $_{i, t}+\beta_{5} \ln$ asstes $_{i, t}+\beta_{6} \ln$ credit $_{i, t}+\beta_{7} \ln$ all $_{i, t}+$

$+\beta_{8} \ln$ deposit $_{i, t}+\beta_{9} \ln$ financial $_{i, t}+\beta_{10} \ln$ creditdep $_{i, t}+$

$+\beta_{11} \ln$ overhead $_{i, t}+\beta_{12} \ln$ net $_{i, t}+\beta_{13} \ln$ concen $_{i, t}+$

$+\beta_{14} \ln$ roa $_{i, t}+\beta_{15} \ln$ roe $_{i, t}+\beta_{16} \ln$ costin $_{i, t}+\beta_{17} \ln$ zscore $_{i, t}+$

$+\beta_{18} \ln$ loans $_{i, t}+\beta_{19} \ln$ offshore $_{i, t}+\beta_{20} \ln$ remittance $_{i, t}+$

$+\beta_{21} \ln$ free $_{i, t}+\beta_{22} \ln$ unger $_{i, t}+\beta_{23} \ln$ cor $_{i, t}+\beta_{24} \ln$ aml $_{i, t}+$

$+\beta_{25} \ln$ solvency $_{i, t}+v_{i t}+u_{i t}$.

Wyniki estymacji modelu zostały zaprezentowane w tabeli 2. 
Tabela 2. Wyniki estymacji $\mathrm{z}$ wykorzystaniem uogólnionej metody najmniejszych kwadratów w modelu z dekompozycją składnika losowego dla 47 krajów

\begin{tabular}{|c|c|c|c|c|}
\hline \multirow{2}{*}{$\begin{array}{c}\text { Zmienna } \\
\text { niezależna }\end{array}$} & \multicolumn{4}{|c|}{$\begin{array}{l}\text { Statyczny model panelowy z dekompozycją składnika losowego oparty } \\
\text { na uogólnionej metodzie najmniejszych kwadratów (Random effect GLS) }\end{array}$} \\
\hline & 1 & $\mathbf{p}$ & 2 & $\mathbf{p}$ \\
\hline lngdp & -0.0038102 & & & \\
\hline lnbankassets & 0.0954469 & & & \\
\hline Inliquid & 0.1944967 & & & \\
\hline Incentral & -0.076922 & & & \\
\hline lnassets & -0.217358 & & & \\
\hline Incredit & -4.491017 & $* *$ & -4.990187 & $*$ \\
\hline Inall & 4.769247 & $* *$ & 5.225765 & $*$ \\
\hline lndeposit & 0.8430393 & & 1.079245 & $*$ \\
\hline Infinancial & 0.1377851 & & & \\
\hline Increditdep & -0.4717255 & $* *$ & -0.5145453 & $* * *$ \\
\hline lnoverhead & 0.0419234 & & & \\
\hline lnnet & 0.0369694 & & & \\
\hline Inconcen & -0.3160965 & $* * *$ & -0.304671 & $*$ \\
\hline lnroa & -0.0086648 & & & \\
\hline Inroe & -0.4131078 & $*$ & -0.4232077 & $*$ \\
\hline Incostin & 0.0642846 & & & \\
\hline lnzscore & 0.9025669 & $*$ & 1.032334 & $*$ \\
\hline Inloans & 0.455649 & $* *$ & 0.416999 & $*$ \\
\hline lnoffshore & -1.269869 & $*$ & -1.219369 & $*$ \\
\hline Inremittance & 0.4835865 & $*$ & 0.4847437 & $*$ \\
\hline free & 0.0039244 & & & \\
\hline unger & -0.0037111 & & -0.0048409 & $* *$ \\
\hline cor & 0.261689 & $* *$ & 0.3127504 & $*$ \\
\hline aml & 0.0319679 & & & \\
\hline solvency & 0.0209609 & & & \\
\hline const & 2.476952 & & 2.997791 & $*$ \\
\hline Test Walda & 0.00 & & 0.00 & \\
\hline Test Hausmana & 1.00 & & & \\
\hline Test LM & 0.00 & & & \\
\hline
\end{tabular}

Uwaga:

* istotność na poziomie $1 \%$,

** istotność na poziomie $5 \%$,

*** istotność na poziomie $10 \%$.

Źródło: opracowanie własne przy wykorzystaniu pakietu statystycznego STATA. 
W modelu wykorzystano 470 obserwacji dla 47 krajów. O jakości dopasowania modelu świadczy $R^{2}$. Grupy są bardzo małe i dlatego dopasowanie w tym zakresie jest niewielkie $\left(R^{2}\right.$ within 0.2857$)$. Statystyka $R^{2}$ between wynosi 0.1092. Wartość wariancji wynikającej z różnorodności między parami (sigma_u) wynosi 2.02, a wariancji wynikającej z wymiaru czasu (sigma_e) 1.88. Współczynnik rho mówi, jaka część wariancji w modelu wyjaśniona jest przez efekty właściwe (53,4\% wariancji wynika z różnic w panelu). Jeśli rho jest relatywnie duże, to znaczy, że model opisuje zjawisko dość stabilne w czasie. Pomimo niskiej wartości $R^{2}$ within model dość dobrze wyjaśnia zjawisko.

Do badania łącznej istotności parametrów modelu wykorzystuje się test Walda. Hipoteza zerowa głosi, że łączny wpływ parametrów jest statystycznie nieistotny. Analizowany model jest istotny statystycznie (wartość $p$ jest poniżej 0.05 ). Do oceny poprawności wyboru pomiędzy modelem panelowym ze sztucznymi zmiennymi a modelem z dekompozycją składnika losowego służy test Hausmana. Hipoteza zerowa zakłada, że efekty grupowe są nieskorelowane ze zmiennymi objaśniającymi. Wyniki przeprowadzonego testu (wartość $p$ powyżej 0.05) wskazują na słuszność zastosowania modelu panelowego z dekompozycją składnika losowego. Test mnożnika Lagrange’a, zaproponowany przez Breuscha i Pagana, pozwala ocenić czy model z dekompozycją składnika losowego jest statystycznie lepszy niż model bez wyróżniania efektów grupowych (model pooled). Hipoteza zerowa mówi, że wyodrębienie części składnika losowego, specyficznego dla obiektów jest nieuzasadnione. W analizowanym modelu wartość $p$ jest poniżej 0.05 , odrzucamy zatem hipotezę zerową na korzyść hipotezy alternatywnej. Efekty grupowe użyte w modelu są istotne, co potwierdza zasadność wykorzystania modelu z dekompozycją składnika losowego.

Po zastosowaniu testu t-Studenta dotyczącego istotności poszczególnych zmiennych, okazało się iż zmiennymi nieistotnie wpływającymi na model są: wartość PKB w przeliczeniu na jednego mieszkańca $(g d p)$, wskaźnik aktywów banków depozytowych do aktywów sektora bankowego (bankassets), wskaźnik płynnych zobowiązań do PKB (liquid), wskaźnik wielkości aktywów banku centralnego do PKB (central), wskaźnik aktywów banków depozytowo-kredytowych do PKB (asstes), wskaźnik depozytów instytucji finansowych do PKB (financial), wskaźnik kosztów ogólnych (overhead), marża odsetkowa netto (net), rentowność aktywów (roa), wskaźnik kosztów ogólnych do przychodów brutto (costin), indeks wolności gospodarczej (free), indeks $A M L$ zaproponowany przez Komitet Bazylejski $(\mathrm{aml})$, współczynnik wypłacalności dla sektora bankowego (solvency). 


\section{Analiza wyników}

Wśród determinantów wpływających istotnie na wielkość raportów dotyczących transakcji podejrzanych o pranie pieniędzy przesyłanych przez banki do krajowej jednostki analityki finansowej określono te, które związane są z wielkością gospodarki, poziomem jej stabilności oraz strukturą i skalą sektora finansowego (jak i bankowego). Analizę przeprowadzono przy zachowaniu zasady ceteris paribus. Okazuje się, że na liczbę analizowanych raportów nie oddziałuje skala gospodarki mierzona produktem krajowym brutto w przeliczeniu na mieszkańca. Wpływ na taką sytuację ma przede wszystkim poziom restrykcyjności polityki stosowanej w zakresie przeciwdziałania praniu pieniędzy przez poszczególne państwa. Nie bez znaczenia pozostaje również efekt Seszeli.

Dotychczasowe badania wskazywały na pozytywny związek pomiędzy korupcją a praniem pieniędzy. Okazuje się, że ta tendencja ma również wpływ na liczbę raportowanych transakcji. Wśród determinantów mogących oddziaływać na analizowane zjawisko znajduje się indeks wolności gospodarczej, otóż wraz ze wzrostem tego indeksu wolumen raportów powinien spadać. Jednak w praktyce nie obserwuje się takiej zależności. Do oceny zjawiska prania pieniędzy zastosowano dwa wskaźniki. Pierwszym z nich jest uprzednio opisany wskaźnik zaproponowany przez B. Unger i J. Walkera. Okazuje się, że wraz ze wzrostem o jednostkę liczba raportów przesyłanych przez sektor bankowy spada przeciętnie o 0,005\%. Kierunek zmian jest jak najbardziej słuszny, biorąc pod uwagę dotychczasowe badania. Jeżeli natomiast chodzi o siłę wpływu, jest ona niewielka $\mathrm{z}$ dwóch powodów. Po pierwsze indeks ten dotychczas nie został w pełni zaktualizowany. Poza tym odnotowuje się wpływ determinantów związanych ze środowiskiem prawnym. Indeks $A M L$ zaproponowany przez Komitet Bazylejski nie ma związku z liczbą analizowanych raportów. Zależność taka jest wynikiem konstrukcji wskaźnika, a mianowicie uwzględnienia w nim danych pochodzących z lat 2010 i 2011.

Kolejną grupą czynników mogących mieć związek z liczbą przesyłanych raportów dotyczących transakcji podejrzanych przez sektor bankowy do krajowych jednostek analityki finansowej jest skala i struktura sektora finansowego. Okazuje się, że spośród wskaźników zaproponowanych przez T. Becka i A. Demirguc-Kunt, dotyczących rozmiarów sektora finansowego wpływ na analizowaną liczbę raportów wywiera tylko wskaźnik prywatnych kredytów udzielanych przez banki depozytowo-kredytowe i inne instytucje finansowe do PKB (zmienna all). Potwierdza to dotychczasowe stanowisko dotyczące pozytywnego związku pomiędzy wielkością systemu finansowego. 
Najlepiej jednak zmiany dotyczące analizowanej liczby transakcji podejrzanych odzwierciedla skala sektora bankowego. Im większy jest zatem sektor bankowy, tym bardziej jest on narażony na zjawisko prania pieniędzy, a jednocześnie również bardziej skłonny do realizacji polityki w zakresie przeciwdziałania mu. Duże banki mają zatem więcej do stracenia w porównaniu z mniejszymi instytucjami finansowymi, dlatego też wolą realizować działania zmierzające ku ograniczeniu tego zjawiska. Ciekawy wniosek można jednak wysnuć, porównując wyniki dla wskaźnika kredytów udzielanych przez banki do PKB (zmienna credit). Okazuje się bowiem, iż istnieje negatywny związek pomiędzy tymi zmiennymi $(-4,99 \%)$. Wpływ na taką sytuację wywiera większe zainteresowanie „praczy” sposobem lokowania środków finansowych. Poza tym banki zazwyczaj zwracają uwagę podczas analiz na depozyty, a nie na udzielane kredyty. Mechanizm analizy wniosków kredytowych jest trudniejszy do obejścia niż założenie lokaty.

Istnieje związek pomiędzy analizowanymi raportami a efektywnością sektora bankowego. Wraz ze wzrostem stosunku kredytów do depozytów o jeden procent liczba transakcji podejrzanych wzrasta średnio o $0,51 \%$. Nie bez znaczenia pozostaje jednak zyskowność sektora bankowego. Wzrost rentowności kapitału o jeden procent skutkuje spadkiem liczby przedstawionych raportów o $0,42 \%$. Banki nastawione na generowanie zysku przy braku realizacji zasad corporate governance nie są skłonne do wykonywania obowiązków związanych z przeciwdziałaniem praniu pieniędzy. Legalizacja dochodów pochodzących z pierwotnej działalności niezgodnej z prawem staje się dodatkowym źródłem dochodów dla sektora bankowego, szczególnie w krajach będących oazami podatkowymi. Okazuje się jednocześnie, że istnieje negatywny związek pomiędzy koncentracją sektora bankowego a liczbą przesyłanych raportów. H. Geiger i O. Wuensch (2006) tłumaczyli takie zjawisko wpływem poziomu konkurencji. Działanie takie było jednak charakterystyczne dla mniejszych banków. Duże banki ze względu na możliwość utraty reputacji skłaniają się ku przestrzeganiu przepisów związanych z przeciwdziałaniem praniu pieniędzy. W analizowanym przypadku wpływ na taki wynik ma przede wszystkim poziom rozwoju gospodarczego kraju oraz przynależność do krajów będących oazami podatkowymi. W słabiej rozwiniętych gospodarczo krajach, które jednocześnie cechują się zazwyczaj wyższą koncentracją sektora bankowego, przesyłanych jest mniej raportów dotyczących transakcji podejrzanych. Należy również zwrócić uwagę na stabilność sektora bankowego określaną przez T. Becka i A. Demirguc-Kunt przy wykorzystaniu wskaźnika - z. Wzrost o jeden procent tego wskaźnika skutkuje wzrostem raportowanych transakcji przeciętnie o $1,03 \%$. 
Dotychczasowe badania wskazywały na wpływ globalizacji sektora bankowego jako czynnika ułatwiającego pranie pieniędzy. Funkcjonowanie $e$-bankingu dodatkowo wzmacnia jego siłę. Opisaną zależność potwierdza również przeprowadzone badanie. Istnieje pozytywny związek pomiędzy wskaźnikiem przepływów środków pieniężnych do PKB a raportowaniem transakcji podejrzanych przez sektor bankowy. Jednocześnie wpływ na tę liczbę wywiera sposób finansowania sektora bankowego. Wzrost finansowania sektora kapitałem zagranicznym skutkuje wzrostem skłonności do przekazywania informacji dotyczących transakcji podejrzanych. Jest to wynik ujednolicania różnych rodzajów polityki wewnętrznej odnoszących się do zwalczania zjawiska, jakim jest pranie pieniędzy. Większość instytucji finansowych ma obecnie międzynarodowy charakter, co potwierdza przedstawioną zależność. Negatywny oddźwięk, jaki ma efekt Seszeli i oazy podatkowe na funkcjonowanie sektora bankowego odzwierciedla wskaźnik depozytów banków z krajów offshore do depozytów utrzymywanych w bankach krajowych (zmienna offshore).

Sektor bankowy nie utożsamia zmian w zakresie współczynnika wypłacalności ze zmianami w liczbie raportów dotyczących transakcji podejrzanych o pranie pieniędzy.

Reasumując wraz ze wzrostem wielkości systemu finansowego, a szczególnie sektora bankowego, rośnie wolumen raportów przesyłanych przez banki do krajowych jednostek analityki finansowej. Istnieje negatywny związek pomiędzy poziomem koncentracji banków, a przesyłanymi transakcjami podejrzanymi. Instytucje kredytowe cechujące się wyższą zyskownością nie są skłonne do wywiązywania się z obowiązku raportowania transakcji, co wynika z możliwości generowania dodatkowych zysków z legalizacji dochodów pochodzących z działalności niezgodnej z prawem. Im bardziej stabilny jest sektor bankowy, tym więcej informacji przekazywanych jest do krajowych jednostek analityki finansowej. Jednocześnie wzrost efektywności sektora wywiera negatywny wpływ na liczbę przesyłanych raportów. Efekt dzielenia się informacjami dotyczącymi podejrzanej aktywności przez klientów jest wzmacniany w wyniku globalizacji sektora bankowego. Nie bez znaczenia pozostaje stabilność gospodarki. Okazuje się, że wraz ze wzrostem korupcji oraz zjawiska prania pieniędzy spada skłonność sektora do raportowania transakcji. Jednak sam poziom wielkości gospodarki mierzonej produktem krajowym brutto w przeliczeniu na jednego mieszkańca nie wpływa istotnie na analizowaną liczbę raportów dotyczących transakcji podejrzanych przesylanych przez sektor bankowy do krajowych jednostek analityki finansowej. 


\section{Wnioski}

Skala sektora bankowego zgodnie z dotychczasowymi badaniami wywiera istotny wpływ na liczbę transakcji podejrzanych o pranie pieniędzy raportowanych przez banki do krajowej jednostki analityki finansowej. Rozwinięty sektor usług finansowych jest czynnikiem wpływającym pozytywnie na napływ środków pieniężnych pochodzących z pierwotnej działalności niezgodnej z prawem. Jednocześnie duże instytucje finansowe, odgrywające znaczną rolę w funkcjonowaniu bankowości międzynarodowej, ponoszą znaczne ryzyko reputacyjne oraz związane ze stosowanymi wobec nich karami i nie są w związku z tym skłonne do działania wbrew prawu.

Pranie pieniędzy jest czynnością niezwykle zyskowną dla sektora bankowego. Sektor bankowy w krajach, gdzie raportuje się mniej transakcji, cechuje się większym poziomem zysku. W słabiej rozwiniętych krajach, gdzie sektor bankowy najczęściej charakteryzuje się wyższą koncentracją sektora bankowego, przesyłanych jest mniej raportów dotyczących transakcji podejrzanych. Jednocześnie zwraca się uwagę, że łatwiej jest ukryć swoje środki finansowe w dużych instytucjach niż w małych podmiotach, czego potwierdzeniem mogą być toczące się w ostatnim okresie sprawy sądowe. Im bardziej stabilny jest sektor bankowy, tym bardziej jest skłonny do przeciwdziałania praniu pieniędzy. Stanowi ponadto bardziej wiarygodne miejsce legalizacji dochodów.

Duże instytucje finansowe o globalnym zasięgu stosują jednolitą politykę wewnętrzną w zakresie przeciwdziałania praniu pieniędzy. Ustawodawca zwraca uwage na potrzebę wprowadzania takich rozwiązań. Umiędzynarodowienie usług finansowych wymaga stosowania bardziej restrykcyjnych regulacji w tym zakresie, a więc przyczynia się do wywiązywania się banków w obrębie raportowania transakcji.

\section{Bibliografia}

Ailofi, G. i Pieth, M. (2003). Anti - Money Laundering: Leveling the Playing Field. Basel Institute of Governance, Working Paper, 1.

Alesina, A. i Weder, B. (2002). Do Corrupt Governments Receive Less Foreign Aid?, American Economic Review, 92(4), September.

Argentiero, A., Bagella, M. i Busato, F. (2008). Money laundering in a two sector model: using theory for measurement. CEIS Research Paper, 128, Tor Vergata University, CEIS, revised 09 . 
Argentiero, A., Bagella, M. i Busato, F. (2009). Money Laundering in a Microfounded Dynamic Model: Simulations for the U.S. and the EU-15 Economies, Review of Law \& Economics, 5(2), Article 4.

Barro, R.J. (1990). The Stock Market and Investment, Review of Financial Studies, Society for Financial Studies, 3(1).

Bartlett, B.L. (2002). The negative effects of money laundering economic development. International Economics Group Dewey Ballantine LLP dla The Asian Development Bank Regional Technical Assistance Project No. 5967 Countering Money Laundering in The Asian and Pacific Region, maj.

Bungard, C. (2001). Offshore banking in the British Dependencies, Touro International Law Review, 141.

Butler, H. i Ribstein, L. (2006). The Sarbanes - Oxley Debacle, AEI Liability Studies. The AEI Press.

Cavalcante Veiga, L.H., Pinto de Andrade, J. i Rossi de Oliveira, A.L. (2006). Money Laundering, Corruption and Growth: An Empirical Rationale for a Global Convergence on Anti-money Laundering Regulation, Latin American and Caribbean Law and Economics Association (ALACDE) Annual Papers, Berkley Paper, Berkley Program in Law and Economics.

Chaikin, D. (2009). How effective are suspicious transaction reporting systems?, Journal of Money Laundering Control, 12(3), DOI: 10.1108/13685200910973628.

Chaikin, D. (2009a). Risk - Based Approaches to Combating Financial Crime, Journal of Law and Financial Management, 8(2), December.

Costa, S. (2008). Implementing the New Anti - Money Laundering Directive in Europe: Legal and Enforcement issues. The Italian Case, Global Business and Economics Review, May. DOI: 10.1504/GBER.2008.019985.

Draghi, M. (2007). The Prevention and Suppression of Money Laundering. Parliamentary Committee of Inquiry into Mafia - like Criminal Organizations, Rome: Bank of Italy.

Dyrektywa 2005/60 WE Parlamentu Europejskiego i Rady z dnia 26 października 2005 roku w sprawie przeciwdziałania korzystaniu z systemu finansowego w celu prania pieniędzy oraz finansowania terroryzmu, (Dz. Urz. UE, Nr 309 (25.11.2005)).

Fredriksson, G. Muthukumara, M. i Damania, R. (2003). The Presistence of Corruption and Regulatory Compliance Failures: Theory and Evidence, IMF Working Paper, No. 03/172, International Monetary Fund.

Geiger, H. i Wuensch, O. (2006). The Fight Against Money Laundering - An Economic Analysis of Cost-Benefit Paradoxon, Journal of Money Laundering Control, 10(1), DOI: $10.1108 / 13685200710721881$.

Gold, M. i Levi, M. (1994). Money Laundering in the UK: An Appraisal of Suspicious Based Reporting. London: Police Foundation.

Grzywacz, J. (2010). Pranie pieniędzy, metody, raje podatkowe, zwalczanie. Warszawa: Oficyna Wydawnicza SGH.

Hannan, M. i Ross, S. (2007). Money Laundering Regulation and risk - based decision making, Journal of Money Laundering Control, 10(1).

Herdman, R.C., (1995). Money laundering. Information Technologies for the Control of Money Laundering, Washington, DC.: U.S. Congress, Office of Technology Assessment.

Holmstrom, B. i Milgrom, P. (1991). Multitask Principal - Agent Analyses: Incentive Contacts, Asset Ownership, and Job Design, Journal of Law, Economics and Organization, Issue 7. 
Leite, C.A. i Weidmann, J. (1999). Does Mother Nature Corrupt? Natural Resources, Corruption and Economic Growth, IME Working Paper, No. 99/85.

Levine, R. i Renelt, D. (1991). Cross-coutry studies of growth and policy: methodological, conceptual, and statistical problems, Policy Research Working Paper Series, 608, The World Bank.

Masciandaro, D. (2004). Combating black money: money laundering and terrorism finance, international cooperation and the G8 role, paper prepared for the Conference „Security, Prosperity and Freedom: why America Leeds the G8”, Bloomington, June.

Masciandaro, D. (2007). Economics of money laundering: A primer. Paolo Baffi Centre. Working Paper, No. 171.

Mauro, P. (1995). Corruption and Growth, The Quarterly Journal of Economics, August.

Mauro, P. (1997). The Effects of Corruption on Growth, Investment, and Government Expenditure: A Cross-Country Analysis. W: Corruption and the Global Economy, Institute for International Economics.

Mitchell, D.J. (2002). U.S. Government Agencies Confirm That Low - Tax Jurisdictions are not Money Laundering Havens, Prosperitas, II, I.

Pellegrina, L. i Masciandaro, D. (2009). The Risk - Based Approach in the New European Anti - Money Laundering Legislation: A Law and Economics View, Review of Law and Economics, 5(2), 6. DOI: 10.2202/1555-5879.1422.

Quirk, P. (1997). Money laundering: Muddying in the Macroeconomy, Finace\&Development.

Reuter, P. i Truman, E. (2004). Chasing Dirty Money: The Fight Against Money Laundering. Washington: Institute for International Economics.

Salifu, A. (2009). he impact of internet crime on development, Journal of Financial Crime, 15(4).DOI: 10.1108/13590790810907254.

Schneider, F. (2007). Money Laundering: some preliminary empirical findings. Discussion paper. Department of Economics, University of Linz.

Schneider, F. i Windischbauer, U. (2008). Money Laundering: Some Facts, European Journal of Law and Economics, 26(3).

Schneider, F. (2010). Turnover of Organized Crime and Money Laundering: some preliminary empirical findings, Public Choice, 144(3), DOI: 10.1007/s111127-010-9676-8.

Takats, E. (2007). A Theory of „Crying Wolf”: The Economics of Money Laundering Enforcement, IMF Working Paper, 07/81, International Monetary Fund. DOI:10.1093/jleo/ewp018.

Takats, E. (2008). Tax Rate Cuts and Tax Compliance - The Laffer Curve Revisited. IMF Working Papers, International Monetary Fund.

Unger, B. i van Waarden, F. (2009). How to Dodge Drowning in Data? Rule- and Risk-Based Anti Money Laundering Policies Compared, Review of Law \& Economics, 5(2), Article 7. 


\title{
Rozdział VI
}

IWONA SROKA*

\section{Rola repozytoriów transakcji w zwiększeniu transparentności rynku derywatów}

\begin{abstract}
Streszczenie
Artykuł porusza kwestie związane funkcjonowaniem repozytoriów transakcji - instytucji działających w celu gromadzenia, przechowywania i przetwarzania informacji o kontraktach pochodnych zawieranych zarówno na rynkach regulowanych, jak i w obrocie niezorganizowanym. Ma również na celu ocenę wpływu nowych regulacji w tym zakresie na funkcjonowanie podmiotów działających na rynku finansowym, w tym regulatorów rynku.

W materiale opisane zostały przesłanki powołujące do życia tego typu instytucje, międzynarodowe zalecenia dotyczące funkcjonowania repozytoriów, podstawy prawne ich działalności oraz funkcje, jakie spełniają na rynku finansowym.

Materiał w szczególności koncentruje się na rynku Unii Europejskiej oraz opisuje działalność repozytorium transakcji funkcjonującego na polskim rynku finansowym. Obowiązek raportowania do repozytoriów, będący pokłosiem ostatniego kryzysu finansowego, wszedł w życie w UE 12 lutego 2014 roku.
\end{abstract}

Słowa kluczowe: repozytorium transakcji, instrumenty pochodne, EMIR, rynek finansowy.

\begin{abstract}
The paper discusses issues relating to the activity of trade repositories: institutions established to collect, maintain and process details of derivative contracts concluded on regulated markets and in OTC trading. It also aims to assess the impact of new regulations to the financial market participants, including market regulators.

The paper outlines the rationale behind the creation of trade repositories, the international guidelines applicable to trade repositories, the legal basis of their activity, as well as their functions on the financial market.
\end{abstract}

* Dr Iwona Sroka - Prezes Zarządu Krajowego Depozytu Papierów Wartościowych SA oraz izby rozliczeniowej KDPW_CCP SA. Adiunkt w Katedrze Gospodarki Narodowej na Wydziale Zarządzania Uniwersytetu Warszawskiego; e-mail: iksroka@gmail.com. 
The paper focuses in particular on the European Union market and describes the activities of the trade repository present on the Polish financial market. The obligation of reporting to trade repositories in the wake of the recent financial crisis came into effect in the EU on 12 February 2014.

Keywords: trade repository, derivatives, EMIR, financial market.

\section{Wstęp}

Za początek ostatniego wielkiego kryzysu na światowych rynkach finansowych przyjęło się powszechnie przyjmować upadek banku Lehman Brothers we wrześniu 2008 r. (Singh i Thomas 2011), a jego przyczyną były kłopoty globalnych instytucji finansowych, spowodowane niekontrolowanym wzrostem rynku derywatów, zwłaszcza z rynku OTC (Carney 2013, s. 12). Rynek OTC (over-the-counter), będący rynkiem pozagiełdowym i nieregulowanym, praktycznie wymknął się spod kontroli organów nadzorczych, które nie dysponowały narzędziami, aby zmierzyć jego skalę i na czas podjąć odpowiednie kroki ostrożnościowe. Najlepszym przykładem obrazującym skalę tej niekontrolowanej części rynku instrumentów pochodnych są dane porównujące dzienne obroty na polskim rynku derywatów: według danych NBP za pierwsze 9 miesięcy $2013 \mathrm{r}$. rynek pozagiełdowych instrumentów pochodnych był blisko 13-krotnie większy niż rynek giełdowy (zob. tab. 1).

Aby podjąć skuteczne działania zapobiegające powstawaniu kolejnych zawirowań na rynkach oraz doprowadzić do złagodzenia skutków ostatniego kryzysu, konieczne było podjęcie współpracy na szczeblu międzynarodowym. Za kluczowe przyjmuje się zalecenia grupy G-20, które zapoczątkowały szereg inicjatyw regulacyjnych na całym świecie. Ich przejawem jest

Tabela 1. Średnie dzienne obroty netto na polskim rynku instrumentów pochodnych w latach 2009-09.2013 (w mln PLN)

\begin{tabular}{|c|r|r|r|r|r|}
\hline & \multicolumn{1}{|c|}{$\mathbf{2 0 0 9}$} & \multicolumn{1}{c|}{$\mathbf{2 0 1 0}$} & \multicolumn{1}{c|}{$\mathbf{2 0 1 1}$} & \multicolumn{1}{c|}{$\mathbf{2 0 1 2}$} & IX 2013 \\
\hline Pozagiełdowe instrumenty pochodne: & 5912,2 & 7638,3 & 10822,3 & 9094,0 & 11403,6 \\
\hline procentowe & 3954,0 & 5824,1 & 9008,0 & 7461,8 & 9792,7 \\
\hline walutowe & 1958,2 & 1814,2 & 1814,3 & 1632,2 & 1610,9 \\
\hline Giełdowe instrumenty pochodne: & 1059,8 & 1413,2 & 1442,2 & 870,0 & 889,3 \\
\hline walutowe & 23,4 & 15,3 & 26,5 & 21,7 & 41,6 \\
\hline związane z rynkiem akcji & 1034,6 & 1397,9 & 1415,7 & 848,3 & 847,6 \\
\hline
\end{tabular}

Źródło: Narodowy Bank Polski. Rynek giełdowy obejmuje jedynie instrumenty notowane na GPW w Warszawie. 
m.in. reforma rynku kapitałowego w USA, znana powszechnie jako DoddFrank Act czy inicjatywy legislacyjne Unii Europejskiej (CRA, CRD, EMIR, MiFID II/MiFIR, RRD) ${ }^{1}$ (Lannoo 2013).

W niniejszym artykule poruszone zostaną kwestie obowiązku raportowania oraz funkcjonowania repozytoriów transakcji w Unii Europejskiej.

\section{Międzynarodowe zalecenia w zakresie zwiększenia bezpieczeństwa rynków finansowych}

Brak wiedzy o skali ryku oraz zaangażowaniu poszczególnych podmiotów w transakcje w derywatach, zwłaszcza OTC, zaburzył prawdziwy obraz rynku i stał się powodem ogólnoświatowego kryzysu. Efektem diagnozy przyczyn kryzysu były m.in. uzgodnienia grupy G-20. 26 września 2009 r. na szczycie organizacji w Pittsburghu uzgodniono, że do końca 2012 r. wszystkie zestandaryzowane kontrakty pochodne, będące przedmiotem obrotu poza rynkiem regulowanym, powinny być rozliczane za pośrednictwem izb rozliczeniowych CCP oraz że kontrakty te należy zgłaszać do repozytoriów transakcji (Rozporządzenie Parlamentu Europejskiego i Rady (UE) NR 648/2012 z dnia 4 lipca 2012 r. w sprawie instrumentów pochodnych będących przedmiotem obrotu poza rynkiem regulowanym, kontrahentów centralnych i repozytoriów transakcji). W Unii Europejskiej nie udało się dotrzymać tego terminu, gdyż obowiązek raportowania wszedł w życie dopiero 12 lutego 2014 r., a rozliczanie derywatów z rynku OTC przez izby rozliczeniowe CCP nastąpi prawdopodobnie pod koniec $2014 \mathrm{r}$.

W 2010 r. w wydanym przez Bank for International Settlements dokumencie Considerations for trade repositories in OTC derivatives markets (Committee on Payment and Settlement Systems... 2010) zostały zawarte zalecenia dotycząca funkcjonowania repozytoriów transakcji. Obejmują one następujące kwestie:

1) uwarunkowania prawne (repozytoria transakcji powinny być umocowane w porządku prawnym danej jurysdykcji);

2) dostęp do danych i transparentność (repozytoria powinny udostępniać informacje odpowiednim organom nadzorczym oraz publicznie w zależności od ich potrzeb);

1 CRA - Credit Rating Agencies Regulation; CRD - Capital Requirements Directive; MiFID II/MiFIR - Markets in Financial Instruments Directive and Regulation, RRD - Resolution and Recovery Directive. 
3) niezawodność działania (należy zidentyfikować źródła ryzyka operacyjnego i ograniczać je poprzez opracowanie niezawodnych i bezpiecznych systemów i procedur; systemy repozytoriów powinny być skalowalne oraz dysponować planem ciągłości działania);

4) zarządzanie (transparentne procedury zarządzania powinny zapewnić pogodzenie wymogów interesu publicznego oraz celów właścicieli i uczestników; osoby zarządzające powinny rozumieć szczególną rolę repozytoriów dla rynku);

5) dostęp i uczestnictwo (repozytoria powinny zapewnić publiczny dostęp do kryteriów uczestnictwa, które powinny równo traktować wszystkie podmioty chcące być uczestnikami repozytorium);

6) ochrona danych (należy wdrożyć odpowiednie warunki i procedury w celu zapewnienia poufności i integralności informacji przechowywanych w repozytorium);

7) terminowe prowadzenie rejestru (repozytorium powinno niezwłocznie rejestrować otrzymywane z rynku informacje oraz zapewnić prawidłowy zapis otrzymanych informacji oraz ich ewidencji);

8) ryzyko połączeń operacyjnych (repozytorium, które posiada krajowe i transgraniczne linki z innymi repozytoriami, a także z instytucjami rynku powinno ocenić potencjalne źródła zagrożeń, które mogą się pojawić oraz zapewnić odpowiednie procedury zarządzania tym ryzykiem);

9) procedury i standardy komunikacji (repozytorium powinno korzystać z powszechnie używanych na rynku, międzynarodowych standardów komunikacji, by umożliwić niezawodną wymianę i rejestrowanie informacji);

10) wydajność (zachowując bezpieczeństwo operacyjne, repozytorium powinno być efektywne kosztowo, by zapewniać opłacalne uczestnictwo w repozytorium oraz powiązania $\mathrm{z}$ innymi podmiotami);

11) transparentność usług (repozytorium powinno zapewnić uczestnikom rynku wystarczający dostęp do informacji o swoich usługach, aby umożliwić im ocenę ryzyka i kosztów związanych z korzystaniem z jego usług);

12) regulacje i nadzór (repozytoria powinny podlegać skutecznemu nadzorowi; w wymiarze krajowym i międzynarodowym regulatorzy powinni ze sobą współpracować w kwestiach nadzoru nad działalnością repozytoriów). 


\section{Rola repozytoriów transakcji w zwiększaniu transparentności rynku}

Repozytorium transakcji to centralny, elektroniczny rejestr informacji o instrumentach pochodnych (Singh i Thomas 2011). Dane gromadzone przez tego typu instytucje mogą być przedmiotem różnorakich analiz rynku, które mogą służyć wzmocnieniu bezpieczeństwa rynku. Niektóre funkcjonujące repozytoria tworzone były oddolnie, z inicjatywy instytucji finansowych, jednak dopiero wprowadzenie regulacji prawnych (Dodd-Frank Act w USA oraz EMIR w UE) spowodowało tworzenie tego rodzaju podmiotów na większą skalę i oferujących określone usługi (Fouque, Joseph i Langsam 2013, s. 24).

Raportowanie informacji o wszystkich zawieranych na rynku kontraktach pochodnych, zwłaszcza z rynku OTC, pozwoli na zwiększenie transparentności zarówno dla sektora nadzorczego, jak i pozostałych uczestników rynku. To z kolei wesprze systemy zarządzania ryzkiem systemowym oraz da organom nadzorczym możliwość podjęcia odpowiednich kroków (przepisów, sankcji, zaleceń). Przyczyni się także do lepszej oceny ryzyka przez kontrahentów transakcji na rynku instrumentów pochodnych (Carney 2013).

Ry s u n e 1. Rola repozytoriów transakcji w zwiększaniu transparentności rynku

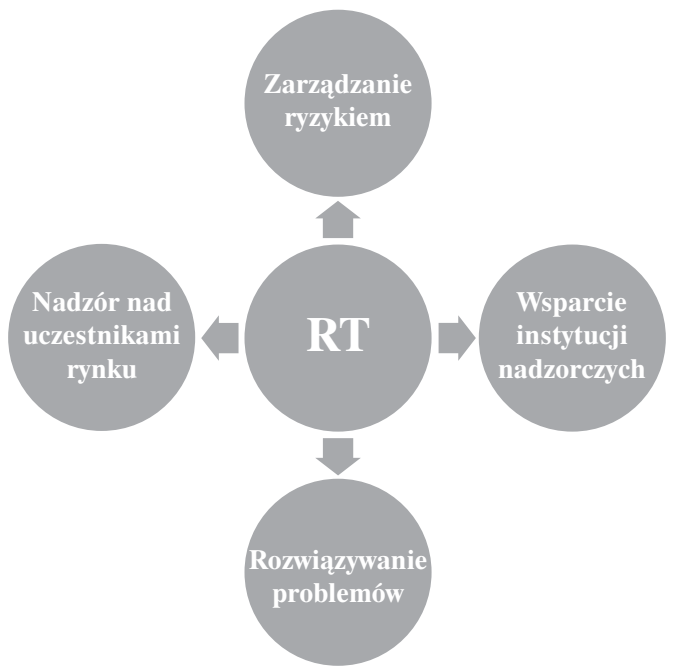

Źródło: opracowanie własne na podstawie: Singh i Thomas (2011). 
Wdrożenie na większości rynków finansowych świata obligatoryjnego raportowania spowoduje, że taki sprawnie działający globalny system informacji pozytywnie wpłynie na poprawę transparentności rynku. Jeśli obroty na rynku pozagiełdowym w Polsce są blisko 13-krotnie wyższe niż na giełdowym, uzyskanie wiedzy na temat tej części rynku pozwoli także na lepszy nadzór nad podmiotami zaangażowanymi w transakcje pochodne OTC.

W prawie europejskim definicję repozytorium transakcji ustanowiono na poziomie Rozporządzenia Parlamentu Europejskiego i Rady (UE) NR 648/2012 z dnia 4 lipca 2012 r. w sprawie instrumentów pochodnych będących przedmiotem obrotu poza rynkiem regulowanym, kontrahentów centralnych i repozytoriów transakcji, znanego bardziej jako European Market Infrastructure Regulation (EMIR).

Zgodnie z art. 2 rozporządzenia EMIR repozytorium transakcji oznacza osobę prawną zajmującą się gromadzeniem i przechowywaniem na szczeblu centralnym danych dotyczących instrumentów pochodnych. Art. 9 z kolei wprowadza obwiązek raportowania i mówi, że kontrahenci transakcji oraz CCP mają zapewnić zgłoszenie szczegółowych informacji na temat każdego zawartego przez siebie kontraktu pochodnego oraz na temat wszelkich zmian lub rozwiązania tego kontraktu repozytorium transakcji, przy czym repozytorium takie musi być zarejestrowane lub uznane przez Europejski Organ Nadzoru Giełd i Papierów Wartościowych (European Securities Market Authority; ESMA). Rozporządzenie EMIR wprowadza ponadto wymóg rejestracji repozytorium w ESMA (art. 55). Repertorium, które uzyska stosowną rejestrację może prowadzić działalność na terenie całej Unii. Szczegółowe wymogi dotyczące repozytoriów transakcji opisuje Tytuł VII rozporządzenia EMIR (art. 78-82).

Pojęcie repozytorium transakcji do polskiego porządku prawnego wprowadziła natomiast nowelizacja ustawy o obrocie instrumentami finansowymi, która weszła w życie 4 sierpnia 2012 r. Art. 48 ust. 5a ustawy stanowi, że Krajowy Depozyt Papierów Wartościowych może prowadzić - na zasadach określonych w odrębnym regulaminie - repozytorium transakcji, czyli działalność polegającą na gromadzeniu i przechowywaniu informacji dotyczących transakcji, których przedmiotem są instrumenty finansowe oraz informacje dotyczące tych instrumentów. 


\section{Obowiązek raportowania w Unii Europejskiej}

Jak już wspomniano, obowiązek raportowania informacji o zawieranych przez przedsiębiorstwa kontraktach pochodnych wynika z Rozporządzenia EMIR. Ma ono na celu przede wszystkim wzrost bezpieczeństwa rynków finansowych i dotyczy nie tylko obowiązku raportowania informacji o transakcjach pochodnych, co ma pozwolić nadzorcom rynku na bieżąco oceniać sytuację na tym rynku, lecz także obliguje do rozliczania derywatów z rynku międzybankowego przez izby rozliczeniowe CCP, wyprowadza jednolite standardy funkcjonowania izb, repozytoriów transakcji oraz modele ich licencjonowania.

Zgodnie z EMIR wejście w życie obowiązku raportowania kontraktów pochodnych do repozytoriów transakcji następuje 90 dni od rejestracji pierwszego repozytorium. W związku z tym, iż ESMA zarejestrowała pierwsze repozytoria 7 listopada 2013 roku, obowiązek raportowy wszedł w życie 12 lutego 2014 roku.

EMIR wprowadza obowiązek raportowania wszystkich kontraktów pochodnych. Zgłaszane muszą być informacje o zawarciu, zmianie i rozwiązaniu kontraktu, niezależnie od rynku, na którym zostały one zawarte (rynek regulowany i OTC). Co istotne, obowiązkiem raportowania objęte są tylko przedsiębiorstwa, w tym także osoby fizyczne prowadzące działalność gospodarczą, a nie dotyczy on osób fizycznych.

Aby wypełnić obowiązek raportowy, zobowiązane do tego przedsiębiorstwa muszą zgłaszać informacje o kontraktach pochodnych do repozytoriów transakcji zarejestrowanych przez Europejski Organ Nadzoru Giełd i Papierów Wartościowych (ESMA). Wybór repozytorium jest dowolny.

Podmioty zobowiązane do raportowania mogą raportować bezpośrednio do repozytorium transakcji, co wymaga uczestnictwa w takiej instytucji bądź wypełniać ten obowiązek za pośrednictwem innego uczestnika raportującego. Zgodnie z unijnymi regulacjami, obowiązek raportowania może być delegowany także do centralnego kontrahenta. Pomimo delegowania raportowania do innego podmiotu, odpowiedzialność za poprawność i terminowość raportowania ciaggle spoczywa na kontrahencie transakcji.

Od 12 lutego 2014 r. informacje na temat każdego zawartego kontraktu pochodnego oraz na temat wszelkich zmian lub rozwiązania tego kontraktu muszą być przekazywane do repozytorium nie później niż w dniu roboczym następującym po zawarciu, zmianie warunków lub rozwiązaniu kontraktu. Ale obowiązek raportowy dotyczy także transakcji zawartych przed 16 sierpnia 2012 r., a aktywnych tego dnia oraz transakcji zawartych 
16 sierpnia 2012 r. i później (tzw. backloading). Na zaraportowanie transakcji zawartych przed 12 lutego 2014 r. przepisy dają pewne okresy przejściowe, co obrazuje tabela 2.

Zgodnie rozporządzeniem EMIR, kody LEI (Legal Entity Identifier) są obligatoryjnym numerem identyfikującym kontrahenta $\mathrm{w}$ procesie przekazywanych do repozytorium transakcji informacji o zawartych kontraktach pochodnych. Zatem każdy podmiot zaangażowany w takie transakcje, bez względu na pozycję, jaką zajmuje w całym procesie zawierania i rozliczania takich transakcji oraz niezależnie od tego czy robi to samodzielnie, czy przez pośrednika, jest zobowiązany do posiadania takiego numeru.

Tabela 2. Backloading

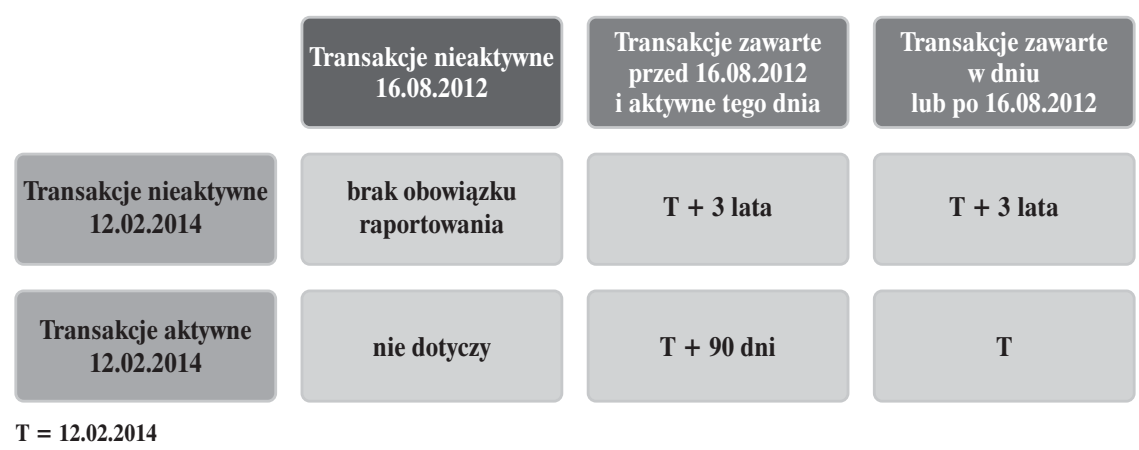

Źródło: opracowanie własne na podstawie: rozporządzenia EMIR.

Za nadawanie kodów LEI odpowiedzialne są specjalnie w tym celu wybrane jednostki, tzw. Local Operating Units (LOU), nadzorowane przez Regulatory Oversight Committee (ROC). Zgodnie z decyzją ROC z 27 grudnia 2013 roku Krajowy Depozyt Papierów Wartościowych uzyskał status jednostki upoważnionej do nadawania kodów LEI.

\section{Repozytorium transakcji na polskim rynku finansowym}

Krajowy Depozyt Papierów Wartościowych jest jak do tej pory jedyną instytucją w Polsce, która świadczy usługi repozytorium transakcji. Nie oznacza to bynajmniej, że przedsiębiorstwa zobligowane do raportowania działające w naszym kraju są zobowiązane do korzystania z usług Krajowego Depozytu. 
KDPW_TR funkcjonuje w oparciu o opublikowany 9 stycznia 2014 roku Regulamin repozytorium transakcji.

Repozytorium Transakcji w KDPW (KDPW_TR) uruchomione zostało 2 listopada 2012 r., a 7 listopada 2013 r. uzyskało rejestrację w Europejskim Organie Nadzoru Giełd i Papierów Wartościowych (ESMA), potwierdzającą zgodność usługi z wymogami rozporządzenia EMIR. Zgodnie z Rozporządzeniem EMIR, decyzja ESMA opatrzona jest vacatio legis wynoszącym 5 dni roboczych od dnia rejestracji. KDPW_TR było jednym z czterech pierwszych repozytoriów transakcji zarejestrowanych przez ESMA, obok DTCC Derivatives Repository Ltd. (DDRL) i UnaVista Ltd., z siedzibą w Wielkiej Brytanii, oraz Regis-TR S.A., z siedzibą w Luksemburgu (Komunikat ESMA..., 2013).

Ta b e l a 3. Lista repozytoriów transakcji zarejestrowanych w ESMA na dzień 6.02.2014

\begin{tabular}{|l|l|l|}
\hline \multicolumn{1}{|c|}{ Repozytorium } & \multicolumn{1}{c|}{$\begin{array}{c}\text { Klasy rejestrowanych } \\
\text { instrumentów }\end{array}$} & \multicolumn{1}{c|}{ Data } \\
\hline $\begin{array}{l}\text { DTCC Derivatives Repository Ltd. } \\
\text { (DDRL) }\end{array}$ & wszystkie klasy instrumentów & 14 listopada 2013 \\
\hline $\begin{array}{l}\text { Krajowy Depozyt Papierów } \\
\text { Wartościowych S.A. (KDPW) }\end{array}$ & wszystkie klasy instrumentów & 14 listopada 2013 \\
\hline Regis-TR S.A. & wszystkie klasy instrumentów & 14 listopada 2013 \\
\hline UnaVista Limited & wszystkie klasy instrumentów & 14 listopada 2013 \\
\hline $\begin{array}{l}\text { CME Trade Repository Ltd. } \\
\text { (CME TR) }\end{array}$ & wszystkie klasy instrumentów & 5 grudnia 2013 \\
\hline $\begin{array}{l}\text { ICE Trade Vault Europe Ltd. } \\
\text { (ICE TVEL) }\end{array}$ & $\begin{array}{l}\text { towarowe, kredytowe, } \\
\text { akcyjne, stopy procentowej }\end{array}$ & 5 grudnia 2013 \\
\hline
\end{tabular}

Źródło: ESMA.

Wniosek rejestracyjny KDPW_TR dotyczył możliwości rejestracji wszystkich rodzajów kontraktów objętych obowiązkiem raportowania (zarówno derywatów giełdowych, jak i z rynku OTC):

1) instrumentów pochodnych na akcje (EQ),

2) instrumentów pochodnych na stopę procentową (IR),

3) walutowych instrumentów pochodnych (CU),

4) kredytowych instrumentów pochodnych (CR),

5) towarowych instrumentów pochodnych $(\mathrm{CO})$,

6) innych instrumentów pochodnych (OT). 


\section{Wnioski}

Rynki finansowe, stając się w zasadzie jednym globalnym systemem finansowym, wymagają specjalnego traktowania i szczególnego nadzoru, ze względu na znaczenie tego sektora dla globalnej gospodarki. Ostatni kryzys finansowy obnażył słabość systemów nadzoru nad rynkami finansowymi. W Stanach Zjednoczonych, gdzie kryzys się rozpoczął, rynek funkcjonował w dużej mierze w oparciu o ustawy pochodzące z czasów Wielkiego Kryzysu... Konieczna zatem była globalna reforma tego sektora, która objęła także kwestie dostarczania nadzorcom odpowiednich informacji o rzeczywistej sytuacji rynkowej.

Gromadzeniu i przetwarzaniu danych o rynku derywatów służyć mają instytucje repozytoriów transakcji. Proces ten tak naprawdę dopiero się zaczął. Już teraz można jednak założyć, że zgromadzenie w jednej bazie danych informacji obrazujących stan rynku derywatów, liczbę i zaangażowanie poszczególnych kontrahentów w różne klasy kontraktów, pozwoli nadzorcom rynku na sprawowanie nad nim właściwej pieczy. Rodzi jednak także pewne obawy, do których można zaliczyć:

1. Problem bezpieczeństwa danych. Gromadzenie w jednym miejscu informacji o kontrahentach wszystkich transakcji na instrumentach pochodnych na rynku, ich wolumenie rodzi groźbę niekontrolowanego wycieku informacji, którego skutki trudno w tym momencie oszacować.

2. Koszty funkcjonowania rynku. Przekazywanie informacji - samodzielnie lub przez pośrednika - pociąga za sobą koszty, którymi obarczone są podmioty zobligowane do raportowania. Oprócz kosztów finansowych doliczyć należy także koszty organizacyjne, koszty pracy, ewentualne sankcje za nienależyte przekazywanie danych. Jest to zwłaszcza problem dla mniejszych podmiotów. Określone koszty poniosły także te instytucje, które powołały do życia repozytoria, zwłaszcza w kwestiach zabezpieczeń dotyczących przechowywanych informacji.

3. Odpowiednie działania nadzorców rynku. Przyczyny kryzysów łatwo jest analizować po ich wystąpieniu; trudniej natomiast je przewidywać i podejmować odpowiednie kroki zapobiegawcze. Ustawodawcy unijni liczą, że nowe przepisy pozwolą instytucjom nadzorującym rynek na realizację polityki antykryzysowej, jednak rynek finansowy ma to do siebie, że szybko ewoluuje i istnieje obawa, iż wkrótce pojawią się nowe instrumenty, nieobjęte obowiązkiem raportowania, które mogą zakłócić prawdziwy obraz i strukturę rynku. 
4. Niedostateczna informacja. Innym istotnym problemem jest fakt, że przepisy dotyczące obligo raportowego zostały wprowadzone bardzo szybko (zgodnie z rozporządzeniem EMIR - 90 dni kalendarzowych od uprawomocnienia się decyzji ESMA o rejestracji repozytorium dla danej klasy instrumentów) i nie były dostatecznie precyzyjne. Wiele wątpliwości było wyjaśnianych przez ESMA już w trakcie okresu po rejestracji pierwszych repozytoriów w tzw. ESMA $Q \& A$ Implementation of EMIR, które nie są przepisem prawa. Wyjaśnienia ESMA dotyczyły między innymi zakresu definicji „przedsiębiorcy” - ESMA przyjęła szeroki zakres stosowania tego pojęcia, które w przypadku prawa polskiego objął także osoby fizyczne prowadzące działalność gospodarczą (http://www.esma.europa.eu/system/ files/2014-164_qa_vi_on_emir_implementation_-_11_february_14.pdf). To z kolei spowodowało, że nie wszystkie podmioty objęte nowymi obowiązkami na czas zapoznały się z nowymi regulacjami oraz zdążyły się do nich przygotować. Banki w Polsce szacują liczbę przedsiębiorstw zaangażowanych w kontrakty pochodne na ok. 8 tys. Tylko mniej więcej połowa $\mathrm{z}$ nich, jak do tej pory, zgłosiła się do KDPW po otrzymanie kodu LEI niezbędnego do prawidłowego raportowania. Nawet jeśli część z firm wyrobiła taki numer poza Polską, to nadal jest duża grupa przedsiębiorstw, które obowiązku na ten moment nie realizują.

5. Sankcje. Rozporządzenie EMIR nie przewiduje sankcji za niedopełnienie obowiązków raportowych. Te muszą w każdym kraju członkowskim wprowadzić lokalni ustawodawcy. W Polsce prace nad sankcjami dopiero trwają. Mają być wprowadzone do ustawy o obrocie instrumentami finansowymi. Bez sankcji prawnych trudno bankom zmusić swoich byłych klientów w transakcjach pochodnych do wyrobienia numeru LEI, niezbędnego do raportowania - w takim wypadku bank złoży raport za jedną stronę transakcji - siebie (Chądzyński 2014, s. 14).

Wprowadzenie we wszystkich jurysdykcjach międzynarodowych zaleceń dotyczących funkcjonowania repozytoriów transakcji, odpowiednie ich umocowanie w lokalnym systemie prawnym oraz późniejsza współpraca repozytoriów w kwestii wymiany informacji, potrwa zapewne jeszcze kilka lat. Regulatorzy liczą także na to, że poniesione koszty związane z obowiązkiem raportowania zostaną zrekompensowane niższym ryzykiem rynkowym.

Obok obowiązku raportowania międzynarodowe regulacje wprowadzają także szereg innych wymogów ostrożnościowych, związanych z funkcjonowaniem rynków finansowych, co w sumie przełoży się na wzrost bezpieczeństwa uczestników tego rynku i pozwoli łagodzić kryzysy. 
Można już podać pierwsze dane dotyczące raportowania do repozytorium transakcji w KDPW. Pierwszego dnia działalności KDPW_TR wpłynęły raporty dotyczące 112 tysięcy transakcji, a na dzień 16 lutego 2014 r. zaraportowane zostały informacje dotyczące już 339 tysięcy transakcji. Są to zarówno transakcje zawarte na bieżąco, jak i historyczne - objęte obowiązkiem raportowym. Rynek nie dysponuje dokładną liczbą transakcji z rynku OTC, można natomiast porównać skalę rynku regulowanego: w styczniu 2014 roku na Giełdzie Papierów Wartościowych w Warszawie zrealizowano 301,6 tys. transakcji na kontraktach pochodnych i opcjach, a w całym $2012 \mathrm{roku}-3,2 \mathrm{mln}$ (http://www.gpw.pl/statystyki_pochodne). Biorąc pod uwagę te dane - wydaje się, że to dużo.

Tabela 4. Podstawowe statystyki KDPW_TR

\begin{tabular}{|l|c|c|}
\hline & 12 lutego 2014 & 16 lutego 2014 \\
\hline Liczba uczestników KDPW_TR & 73 & 83 \\
\hline Liczba przyjętych raportów & 267000 & 759000 \\
\hline Liczba zaraportowanych transakcji & 112000 & 339000 \\
\hline Liczba obsłużonych wniosków o nadanie kodu LEI & 4000 & 4300 \\
\hline Liczba nadanych kodów LEI & 2600 & 2900 \\
\hline Liczba kodów oczekujących na wydanie & 300 & 250 \\
\hline
\end{tabular}

Źródło: KDPW.

\section{Bibliografia}

Bank of England (2012). A network model of financial system resilience. Working Paper, No. 458. Londyn: Bank of England.

Buenaventura, R. i Ross, V. (2013). Transaprency and financial stability, Financial Stability Review, 17. Paris: Banque de France.

Carney, M. (2013). Completing the G20 reform agenda for strengthening over-the-counter derivatives markets, Financial Stability Review, 17. Paris: Banque of France.

Chądzyński, M. (2014). Nie ma sankcji za brak raportu o transakcjach pochodnych, Dziennik Gazeta Prawna, 20 stycznia.

Committee on Payment and Settlement Systems, Technical Committee of the International Organization of Securities Commissions (2010). Considerations for trade repositories in OTC derivatives markets. Bazylea: Bank for International Settlements

Dombret, A. i Lucius, O. (2013). Stability of the Financial System: Illusion Or Feasible Concept?. Glos (UK): Edward Elgar Publishing 
Fouque, J.P., Joseph, A. i Langsam, J.A. (2013). Handbook on Systemic Risk. Cambridge: Cambridge University Press.

Goodhart, C., Hartmann, P., Llewellyn, D., Rojas-Suarez, L. i Weisbrod, S. (1998). Financial Regulation: Why, How and Where Now? Londyn: Routledge.

http://www.esma.europa.eu/system/files/2014-164_qa_vi_on_emir_implementation_-_11_february 14.pdf.

http://www.gpw.pl/statystyki_pochodne.

Komunikat ESMA z dnia 7.11.2013. Pobrano z: http://www.esma.europa.eu/news/ PRESS-RELEASE-ESMA-registers-DDRL-KDPW-Regis-TR-and-UnaVista-traderepositories? $\mathrm{t}=326 \& \mathrm{o}=$ home.

Lannoo, K. (2013). The New Financial Regulatory Paradigm: A transatlantic perspective, CEPS Policy Brief, 287, 21 March, Bruksela. Pobrano z: http://ceps.eu/book/new-financialregulatory-paradigm-transatlantic-perspective.

NBP (2013). Rozwój systemu finansowego w Polsce. Warszawa: Narodowy Bank Polski.

Rozporządzenie Parlamentu Europejskiego i Rady (UE) NR 648/2012 z dnia 4 lipca 2012 r. w sprawie instrumentów pochodnych będących przedmiotem obrotu poza rynkiem regulowanym, kontrahentów centralnych i repozytoriów transakcji.

Singh, M.K. i Thomas, S. (2011). Trade Repositories and their role in the financial marketplace. IGIDR Finance Research Group Technical Report. Mumbai. Indira Gandhi Institute of Development Research. Pobrano z: http://www.igidr.ac.in/FSRR/PDF/201103_trade repositories_technote.pdf. 


\title{
Rozdział VII
}

BOŻENA FRĄCZEK*

\section{Niski poziom alfabetyzacji finansowej społeczeństwa - jako bariera ograniczająca rozwój rynku kapitałowego}

\begin{abstract}
Streszczenie
Znaczenie inwestorów indywidualnych dla rynku finansowego, a zwłaszcza jego rozwoju jest wieloaspektowe. Ważny jest zarówno sam udział inwestorów indywidualnych w poszczególnych segmentach tego rynku (w tym w rynku kapitałowym), socjodemograficzne cechy inwestorów, jak i ich zachowania wpływające na podejmowanie decyzji inwestycyjnych. Wnioski z badań prowadzonych na całym świecie potwierdzają błędy w każdym z tych obszarów. Za główną przyczynę tych błędów uznaje się niewystarczający poziom alfabetyzacji finansowej społeczeństw poszczególnych krajów. Poprawa poziomu alfabetyzacji finansowej społeczeństwa mogłaby w znacznym stopniu przyczynić się do rozwoju rynku kapitałowego.
\end{abstract}

Słowa kluczowe: alfabetyzacja finansowa, edukacja finansowa, inwestor indywidualny, inwestowanie.

\begin{abstract}
The role of individual investors for development at the financial market is multifaceted. It includes the first of all the scale as well as the range of participation of this type of investors in the financial market, Research conducted in this field show the meaning of many sociodemographic features for financial behaviors and financial decision making of individuals, Results of research confirm a lot of mistakes made by individual financial consumers. The main reason is considered to be the lack or unsufficient level of financial literacy (financial knowledge, financial skills, financial awareness and financial behaviors). Increase of the low level of financial literacy of societies of particular countries may contribute to development of financial market.
\end{abstract}

Keywords: financial literacy, financial education, indywidual investor, investing.

\footnotetext{
* Dr Bożena Frączek - Katedra Bankowości i Rynków Finansowych, Uniwersytet
} Ekonomiczny w Katowicach; e-mail: b.fraczek@ue.katowice.pl. 


\section{Wstęp}

Alfabetyzacja finansowa jest pojęciem dosyć pojemnym. Według OECD alfabetyzacja finansowa obejmuje: wiedzę, umiejętności, postawy i zachowania, a także świadomość finansową, które są niezbędne do podejmowania właściwych i świadomych decyzji finansowych, umożliwiających osiągnięcie dobrobytu finansowego (OECD INFE 2011, s. 3). Za najważniejsze narzędzie umożliwiające poprawę niskiego poziomu alfabetyzacji finansowej uważa się edukację finansową. OECD definiuje edukację finansową jako proces, który umożliwia konsumentom finansowym/inwestorom indywidualnym lepsze zrozumienie podstawowych pojęć finansowych, istoty produktów finansowych i poszczególnych rodzajów ryzyka finansowego, rozwijanie umiejętności finansowych, nabywanie pewności siebie oraz zaufania do rynku finansowego (OECD 2005).

Prowadzone na całym świecie badania wskazują na niesatysfakcjonujący poziom alfabetyzacji finansowej społeczeństw poszczególnych krajów. Brak wystarczającej wiedzy, odpowiednich umiejętności oraz niewystarczająca świadomość finansowa ograniczają udział tych społeczeństw w rynku produktów i usług finansowych, zwłaszcza tych ryzykownych. Analfabetyzm finansowy jest dodatkowo potęgowany przez niekorzystne socjodemograficzne cechy potencjalnych inwestorów, co zostało zweryfikowane w wielu badaniach przeprowadzonych na całym świecie. Wśród tych cech wyróżnia się przede wszystkim płeć (OECD/INFE 2013; Berggren i Gonzalez 2010, s. 44), wiek (Atkinson 2007, s. 41; Atkinson i Messy 2012), dochód i poziom edukacji (Atkinson i Messy 2012), a także normy kulturowe (Nannyanzi 2009) i motywację (Mandell i Klein 2007). Przytoczone badania w większości opierają się na ankietach weryfikujących poziom podstawowej wiedzy i podstawowych umiejętności finansowych i coraz częściej bazują na jednakowych testach (pytaniach) w wyniku czego są porównywalne.

Globalny kryzys finansowy zwrócił szczególną uwagę na problem edukacji finansowej społeczeństw jako instrumentu wspomagającego rozwój rynku finansowego, w tym rynku kapitałowego (Caratelli i Ricci 2012, s. 115). W wyniku prowadzonych badań rozpoznano wpływ poziomu alfabetyzacji finansowej na szereg aspektów związanych z funkcjonowaniem rynku finansowego, np. na decyzje w zakresie oszczędności zwłaszcza długoterminowych (Christiansen, Joensen i Rangvid 2008, s. 465-496). Rozpoznano także wpływ określonych elementów powiązanych z alfabetyzacją (np. profil wykształcenia) na nabywanie instrumentów ryzykownych, zwłaszcza akcji. 
Wśród wielu różnych podmiotów funkcjonujących na rynku kapitałowym (oraz innych segmentach rynku finansowego) na szczególną uwagę zasługują inwestorzy indywidualni, reprezentowani przez gospodarstwa domowe. Ważna jest zarówno ich liczba, zaangażowanie kapitałowe, jak i podejście do inwestowania wpływające na ich aktywność na rynku. Z parametrów tych wynika udział inwestorów indywidualnych w kapitalizacji rynku oraz w jego obrotach. Ostatni wymieniony aspekt uczestnictwa inwestorów indywidualnych na rynku kapitałowym bezpośrednio wpływa na jego płynność. Toteż inwestorzy indywidualni często są postrzegani jako tzw. dostarczyciele płynności.

Wiele badań potwierdza także pozytywny wpływ inwestorów indywidualnych na zmienność stóp zwrotu na rynku akcji (Foucault, Sraer i Thesmar 2011, s. 1370). Należy jednak zwrócić uwagę, że parametry opisujące zaangażowanie inwestorów indywidualnych na rynku kapitałowym nie są stałe w czasie. Odnotowano nawet, że w niektórych okresach podlegają one znacznym fluktuacjom, które są bardzo istotne dla funkcjonowania rynku. Dodatkowo należy zaznaczyć, że wiele badań skupiających się wokół aktywności inwestorów indywidualnych, np. na rynku akcji, potwierdza ich rolę jako twórców tzw. szumu. Co prawda, zwraca się uwagę na fakt, że nie tylko inwestorzy indywidualni oraz że nie wszyscy inwestorzy indywidualni są twórcami „szumu” (Foucault, Sraer i Thesmar 2011, s. 1400). Jednak w odróżnieniu od inwestorów instytucjonalnych, inwestorzy indywidualni są uważani za mniej poinformowanych, mają psychologiczne uprzedzenia, toteż często przypisuje im się znaczny udział w ograniczaniu rozwoju rynku kapitałowego.

Prowadzone badania potwierdzają także irracjonalność inwestorów indywidualnych przy podejmowaniu decyzji inwestycyjnych. Brak zdolności do podejmowania odpowiedzialnych decyzji inwestycyjnych jest często przypisywany powszechnemu brakowi wiedzy finansowej (Lusardi 2008). Jako przyczyny typowych błędnych decyzji finansowych wskazywane są inklinacje behawioralne, takie jak efekt predyspozycji, w wyniku którego inwestorzy wykazują tendencje do przedwczesnej sprzedaży walorów zwyżkujących oraz zbyt długiego przetrzymywania walorów tracących na wartości (Laurent, Campbell i Sodini 2009, s. 393-398).

Można wyszczególnić wiele czynników wpływających na charakter i poziom zaangażowania inwestorów indywidualnych na rynku kapitałowym oraz na zmiany w tym zaangażowaniu. Niewątpliwie jednak jednym z ważniejszych czynników jest poziom alfabetyzacji finansowej nie tylko dotychczasowych, lecz także potencjalnych inwestorów indywidualnych.

Celem niniejszego referatu jest przedstawienie poziomu oraz podkreślenie roli alfabetyzacji finansowej społeczeństw jako dotychczasowych i poten- 
cjalnych inwestorów indywidualnych, stanowiących ważną grupę uczestników rynku kapitałowego.

Przegląd światowej literatury oraz analiza dokumentów nieakademickich wzbudziły zainteresowanie autorki i skłoniły do wstępnej analizy niskiego poziomu alfabetyzacji finansowej społeczeństw różnych krajów jako bariery ograniczającej rozwój rynku kapitałowego z zamiarem potraktowania tych wyników jako sugestii dla dalszych badań.

\section{Poziom alfabetyzacji finansowej potencjalnych inwestorów indywidualnych i jego wpływ na rozwój rynku kapitałowego}

Niski i pogarszający się poziom alfabetyzacji finansowej jest charakterystyczny dla współczesnych społeczeństw krajów zarówno rozwijających się, jak i rozwiniętych. Wyniki prowadzonych badań potwierdzają zarówno występujące braki w wiedzy finansowej i w podstawowych umiejętnościach zarządzania finansami, jak i nieodpowiednie zachowania oraz postawy w odniesieniu do różnych okoliczności związanych z zarządzaniem pieniędzmi.

Ta b e l a 1. Odsetek pozytywnych odpowiedzi w ramach badań weryfikujących poziom wiedzy, pozytywnych zachowań społeczeństw w poszczególnych krajach

\begin{tabular}{|l|c|c|c|}
\hline \multicolumn{1}{|c|}{ Kraj } & Wiedza (w \%) & Zachowania (w \%) & Postawy (w \%) \\
\hline Albania & 45 & 39 & 69 \\
\hline Armenia & 46 & 41 & 11 \\
\hline Czechy & 57 & 48 & 62 \\
\hline Estonia & 61 & 27 & 46 \\
\hline Niemcy & 58 & 67 & 63 \\
\hline Węgry & 69 & 38 & 69 \\
\hline Irlandia & 60 & 57 & 49 \\
\hline Malezja & 51 & 67 & 53 \\
\hline Norwegia & 40 & 59 & 57 \\
\hline Peru & 41 & 60 & 27 \\
\hline Polska & 49 & 43 & 54 \\
\hline RPA & 33 & 43 & 49 \\
\hline Wielka Brytania & 53 & 51 & 67 \\
\hline Brytyjskie Wyspy Dziewicze & 57 & 71 & \\
\hline
\end{tabular}

Źródło: dane OECD, za: Atkinson i Messy (2012, s. 10). 
Wyniki badań wskazują na zróżnicowany poziom wiedzy finansowej w poszczególnych krajach. Należy jednak zaznaczyć, że w żadnym przypadku nie jest to poziom satysfakcjonujący (zawsze poniżej 70\% poprawnych odpowiedzi). Niezadowalający jest także poziom aktywnego i świadomego uczestnictwa inwestorów indywidualnych w rynkach finansowych. Ocena zachowań finansowych konsumentów finansowych wskazuje także na duże zróżnicowanie preferencji, a tym samym postaw i wzorców finansowych.

Okazuje się także, że na niezadawalający poziom alfabetyzacji finansowej w poszczególnych krajach w różnym stopniu wpływają jej poszczególne elementy. Nie obowiązuje jedna zasada, która stanowi o wyższości jednych elementów alfabetyzacji finansowej nad drugimi. Zatem chcąc ograniczać bariery rozwoju rynku kapitałowego poprzez podnoszenie poziomu alfabetyzacji finansowej społeczeństw, należy zwrócić uwagę na wszystkie jej elementy: wiedzę, świadomość, umiejętności oraz postawy i zachowania.

\section{Ry s u n e k 1. Różnice w zrozumieniu koncepcji odsetek}

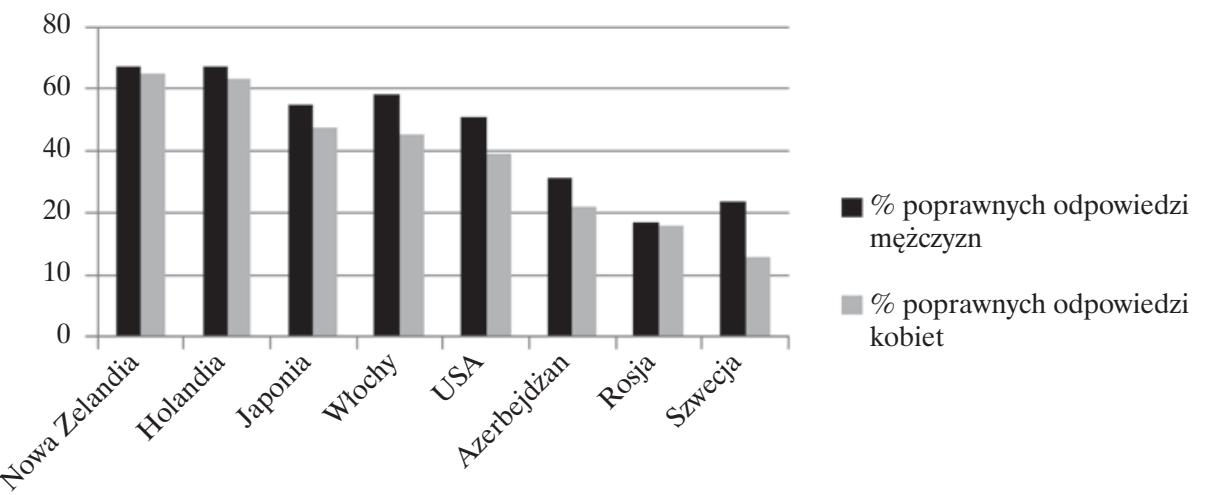

Źródło: dane Banku Światowego.

Pogarszający się poziom alfabetyzacji finansowej jest postrzegany jako jeden $\mathrm{z}$ ważnych czynników wpływających na niesatysfakcjonujący udział inwestorów w rynku akcji oraz innych ryzykownych instrumentów finansowych. Coraz więcej oszczędności jest lokowanych w nieruchomościach, złocie, a także w instrumentach wolnych od ryzyka, takich jak lokaty bankowe czy obligacje.

Analiza problemu niewystarczającego poziomu alfabetyzacji jako bariery rozwoju rynku kapitałowego powinna także uwzględniać szereg czynników 
socjodemograficznych, które wpływają na poziom alfabetyzacji (i tym samym mogą mieć istotne znaczenie dla rozwoju tego rynku). W grupie wspomnianych czynników powinny znaleźć się przede wszystkim płeć, wiek, poziom wykształcenia oraz dochody potencjalnych inwestorów.

\section{Ry s u n e k 2. Różnice w zrozumieniu koncepcji odsetek i kapitalizacji}

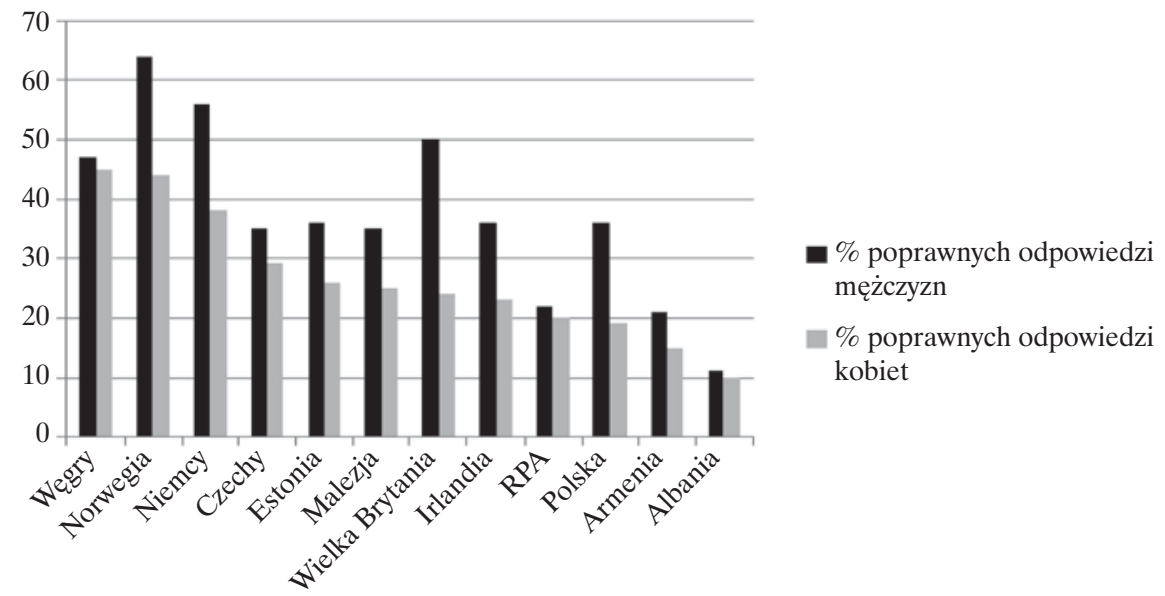

Źródło: dane OECD.

Problem równości płci (a w zasadzie problem jej braku) okazuje się coraz bardziej istotny ze względu na zauważalną różnicę w poziomie alfabetyzacji finansowej pomiędzy kobietami i mężczyznami oraz cechy i rosnący potencjał kobiet, który może być wykorzystany zarówno w biznesie, jak i na rynkach finansowych. Wśród cech kobiet, na które najczęściej zwraca się uwagę są: podejście do ryzyka, zróżnicowane źródła i coraz wyższe dochody, coraz wyższy poziom edukacji oraz coraz dłuży czas trwania życia. Zasadniczo kobiety reprezentują niższy poziom alfabetyzacji, co zostało dowiedzione w wielu badaniach (OECD 2013).

Chociaż poziom alfabetyzacji finansowej kobiet i mężczyzn jest zróżnicowany w poszczególnych krajach, to w każdym przypadku uznawany jest za niewystarczający oraz w każdym z analizowanych przypadków kobiety wypadają gorzej. Jednakże ich specyficzne preferencje w zakresie zarządzania pieniędzmi w tym oszczędzania i inwestowania mogą i powinny być wykorzystane w dalszym rozwoju rynku kapitałowego.

Wiek potencjalnych inwestorów również powinien być brany pod uwage w projektowaniu zmian i ograniczaniu barier na rynku kapitałowym. Zależ- 
ność pomiędzy wiekiem a poziomem alfabetyzacji finansowej ma kształt odwróconego U, co oznacza, że młodzież oraz ludzie starsi dysponują jej niższym poziomem i co bezpośrednio przekłada się na ich zaangażowanie na rynku kapitałowym (zwłaszcza na rynku akcji). W wielu przebadanych krajach wykazano zależność, z której wynika, że niskiemu poziomowi alfabetyzacji towarzyszą złe decyzje inwestycyjne. Jednocześnie zwraca się uwagę, że poprzez wpływ na podejmowane decyzje inwestycyjne alfabetyzacja finansowa wpływa także na skłonności do inwestowania w walory ryzykowne, np. akcje: niższy jej poziom oznacza mniejszą skłonność do tego typu inwestycji (Rooij, Lusardi i Alessie 2007). Należy jednak zauważyć, że zupełnie inne są przesłanki niskiego poziomu alfabetyzacji finansowej u młodzieży i u osób starszych. W przypadku młodych ludzi jest to przede wszystkim niezakończony proces edukacji oraz brak doświadczenia, które to czynniki negatywnie wpływają na poziom wiedzy, umiejętności i świadomości finansowej. U ludzi starszych zwraca się zaś uwagę na pogorszenie funkcji poznawczych, a w związku z tym możliwości przyswajania, zachowywania i stosowania wiedzy finansowej (Atkinson i Messy 2012, s. 446-448).

Do kolejnych cech, które są w ścisłej zależności z poziomem alfabetyzacji finansowej, a tym samym z zaangażowaniem na rynku kapitałowym, należą poziom wykształcenia oraz poziom zamożności (dodatkowo powiązany z cyklem życia). W zakresie wykształcenia zwraca się uwagę na długość pobieranej nauki oraz na profil edukacji. Na przestrzeni ostatnich dwudziestu lat przeprowadzonych zostało wiele badań weryfikujących tezę, że wyedukowani inwestorzy są bardziej skłonni do dokonywania inwestycji $\mathrm{w}$ akcje w porównaniu z inwestorami mniej wykształconymi. Okazuje się, że inwestorzy z wyższym wykształceniem częściej inwestują w akcje niż inwestorzy z wykształceniem średnim czy podstawowym. W rozważaniach dotyczących wpływu rodzaju wykształcenia na zaangażowanie inwestorów na rynkach akcji ważnym punktem wyjścia są koszty związane z inwestowaniem $\mathrm{w}$ te instrumenty. I nie chodzi tu bynajmniej o koszty, które ponosi każdy inwestor, a związane z zakupem akcji czy innych walorów ryzykowanych, ale przede wszystkim o koszty pozyskania wiedzy na temat inwestowania oraz koszty pozyskania umiejętności selekcjonowania i interpretowania informacji wykorzystywanych w procesach inwestycyjnych (w tym także koszty czasu przeznaczonego na zrozumienie tych kwestii). Takie ujęcie problemu pozwala na postawienie hipotezy, że inwestorzy, którzy potrafią lepiej i szybciej wykorzystać dostępne informacje o rynkach akcji i możliwościach inwestowania, ponoszą niższe koszty uczestnictwa, zatem prawdopodobieństwo ich udziału w rynku tych walorów jest wyższe. Ponadto wykazano, że ekonomiści 
są bardziej skłonni do inwestowania w akcje niż inwestorzy o innym wykształceniu. Udowodniono także korzystniejszy poziom alfabetyzacji finansowej w przypadku pracowników umysłowych (w porównaniu z fizycznymi), urzędników i menedżerów, a także osób które są dobre w dziedzinie matematyki i logicznego myślenia (Spataro i Corsini 2013, s. 3).

Zidentyfikowanie luk w alfabetyzacji finansowej społeczeństw, a następnie ich sukcesywne likwidowanie stanowi duże wyzwanie, ale i szansę dla rozwoju rynku kapitałowego. Wyższy poziom alfabetyzacji finansowej sprzyja zwiększeniu udziału inwestorów indywidualnych w rynku. Ważny jest zarówno wzrost liczby inwestorów, jak i pojawienie się inwestorów o nieco odmiennych cechach (kobiety, inne niż dotychczas grupy zawodowe). W takich okolicznościach dużym wyzwaniem dla rynku kapitałowego byłaby konieczność dostosowania oferty produktowej do profilu danej grupy inwestorów. Poprawa poziomu alfabetyzacji, przejawiająca się także w poprawie świadomości finansowej inwestorów indywidualnych, powinna pozytywnie wpłynąć na ich zachowania, co także jest bardzo korzystne dla sprawnego funkcjonowania rynku.

\section{Obszary wpływu edukacji finansowej na rozwój rynku kapitałowego}

Znaczenie oraz odpowiednie podejście do alfabetyzacji finansowej może mieć ogromny wpływ na rozwój poszczególnych segmentów rynku finansowego, zwłaszcza rynku kapitałowego, ponieważ podnoszenie poziomu alfabetyzacji finansowej umożliwia realizacje celów, które sprzyjają rozwojowi tego rynku. Należą do nich np.:

- tworzenie świadomości finansowej lub poprawa jej poziomu;

- nabywanie lub poprawa umiejętności niezbędnych przy wykorzystywaniu produktów i usług finansowych;

- zwiększenie ochrony konsumentów finansowych;

- wspieranie integracji finansowej;

- zmiany zachowań konsumentów.

Finansowa świadomość społeczeństwa oznacza lepsze zrozumienie podstawowych zagadnień i koncepcji finansowych. Obejmuje ona świadomość na temat ryzyka na rynku finansowym, świadomość zalet i wad różnych instrumentów finansowych oraz świadomość możliwości ich wykorzystania. Dla potencjalnych inwestorów niezwykle ważna jest także świadomość możliwości podejmowania odpowiednich działań w sytuacjach wskazujących 
na potencjalne oszustwa lub zagrożenia, które mogą naruszać ich prawa (OECD 2005). W takim rozumieniu świadomość finansowa zwiększa poczucie bezpieczeństwa inwestorów i daje duże szanse na zwiększenie ich udziału w rynku, a także na bardziej przewidywalne reakcje, w mniejszym stopniu narażone na działanie emocji.

Wiedza, jako element alfabetyzacji, ma na celu budowanie umiejętności ludzi do korzystania z produktów i usług finansowych. Odpowiednia wiedza pozwala na podejmowanie decyzji inwestycyjnych spełniających kryteria - w zakresie poziomu wynagrodzenia i ryzyka - dostosowane do profilu inwestora. Inwestorzy nieposiadający odpowiedniej wiedzy finansowej, rozumiejąc własne ograniczenia, często unikają takich zachowań finansowych, które wymagają od nich podejmowania odpowiedzialnych decyzji. Tym samym mogą oni hamować rozwój niektórych produktów i usług finansowych, zwłaszcza tych bardziej wyrafinowanych.

Kolejnym obszarem, poprzez który poziom alfabetyzacji finansowej wpływa na rozwój rynku kapitałowego, jest ochrona konsumentów. Edukacja finansowa, która jest jednym z najważniejszych sposobów zwiększania poziomu alfabetyzacji jest bardzo ważnym (chociaż nie jedynym) narzędziem skutecznej polityki mającej na celu wzmocnienie pozycji konsumentów finansowych na rynku finansowym (OECD 2009). Kwestia ochrony konsumentów na rynku finansowym jest także istotna $\mathrm{z}$ punktu widzenia samych dostawców produktów i usług finansowych, gdyż ich obecność i działalność w dużym stopniu zależy od kondycji ich potencjalnych klientów. Rolą edukacji finansowej dla ochrony konsumentów jest promowanie praw konsumentów dla ochrony ich własności i finansowego dobrobytu. Idea ochrony konsumentów zwiększa ich poczucie bezpieczeństwa i z dużym prawdopodobieństwem może przyczynić się do zwiększenia zaangażowania na rynku kapitałowym.

Alfabetyzacja finansowa sprzyja także integracji finansowej rozumianej jako dostęp do korzystania z produktów i usług finansowych w przystępnej cenie, w dogodny sposób i z godnością dla klientów (Gardeva i Rhyne 2011). Dostarczenie wiedzy oraz poprawa umiejętności planowania finansowego (zwłaszcza długoterminowego) i zabezpieczania się przed zagrożeniami zwiększa dostęp i skalę korzystania z produktów i usług finansowych.

Poprawa alfabetyzacji finansowej (wzrost wiedzy, umiejętności i świadomości) sprawia, że konsumenci dążą do zmiany zachowań finansowych, np. zaczynają lub poprawiają budżetowanie i planowanie finansowe na poziomie gospodarstwa domowego, a także świadomie oszczędzają i inwestują pieniądze. Nie oznacza to jednak, że twórcy programów edukacyjnych mogą poprzez swoje działania bez problemu wpływać na zachowania konsu- 
mentów. Wręcz przeciwnie, zmiana dotychczasowych zachowań finansowych na oczekiwane jest uwarunkowana wieloma czynnikami, w tym ekonomicznymi (zarówno na poziomie mikro, jak i makro), politycznymi, a także społecznymi. Tworzenie właściwych nawyków w zarządzaniu finansami osobistymi obejmuje także nawyki w obszarze konsumenckiej odpowiedzialności i ostrożności. W tym miejscu warto podkreślić, że zmiany zachowań konsumentów finansowych nie są możliwe bez uprzedniej poprawy alfabetyzacji finansowej (Lewis i Klein 2009).

Przedstawione obszary (cele edukacji finansowej) wpływające na rozwój rynku kapitałowego potwierdzają rolę alfabetyzacji finansowej w rozwoju tego rynku. Tym samym kolejny raz należy podkreślić znaczenie skutecznej edukacji finansowej, poprawiającej wiedzę i umiejętności finansowe, zwiększającej świadomość finansową oraz zmieniającej zachowania finansowe na oczekiwane, bardziej racjonalne i przewidywalne.

\section{Efektywna edukacja finansowa społeczeństwa jako ważny czynnik wpływający na rozwój rynku kapitałowego}

Jak zostało zaznaczone we wstępie, edukacja finansowa, jako narzędzie umożliwiające podniesienie poziomu alfabetyzacji, jest procesem, w wyniku którego inwestorzy/finansowi konsumenci lepiej rozumieją istotę produktów i usług finansowych, koncepcję i istotę ryzyka, potrafią korzystać z dostępnych informacji, instrukcji oraz/lub doradztwa finansowego, nabywają umiejętności i pewności siebie, aby stać się bardziej świadomymi możliwości i ryzyka, aby dokonywać świadomych wyborów i wiedzieć, gdzie zwrócić się o pomoc i jakie podjąć działania w celu osiągnięcia bezpieczeństwa i dobrobytu finansowego.

W zakresie edukacji finansowej zostało podjętych bardzo wiele inicjatyw na całym świecie. Przyjmują one zróżnicowaną formę i prowadzone są w różnym zakresie. Są to działania o zróżnicowanej skali, prowadzone na szczeblu zarówno krajowym, jak i międzynarodowym. Aby edukacja finansowa mogła być skuteczna, należy przeprowadzić obiektywne badania społeczeństwa, na podstawie których określone zostaną główne braki i luki w alfabetyzacji finansowej. Działania te najczęściej przyjmują formę ankiet lub wywiadów face to face. Na podstawie badań można dokonać subiektywnej oceny poziomu alfabetyzacji finansowej oraz identyfikacji potrzeb w zakresie dalszego kształcenia - zarówno na płaszczyźnie merytorycznej, jak i w odniesieniu do poszczególnych grup osób. 
Jednym z ważniejszych sposobów edukacji finansowej są zintegrowane, skoordynowane, wieloaspektowe i wszechstronne narodowe strategie (plany) edukacji finansowej (Narodowe Strategie; NS), do których opracowywania i wdrażania wezwała Organizacja Współpracy Gospodarczej i Rozwoju (OECD) w 2003 roku. Wezwanie zostało skierowane do rządów krajów członkowskich w ramach rozpoczętego międzynarodowego programu edukacji finansowej (OECD 2008). Idea była odpowiedzią na obawę przed skutkami stwierdzonego niskiego poziomu alfabetyzacji społeczeństw poszczególnych krajów. Idea narodowych strategii łączy wysiłki wielu podmiotów z sektora publicznego (np. rządy krajów, banki centralne, właściwe ministerstwa), prywatnego (instytucje i podmioty finansowe) oraz szereg organizacji krajowych i międzynarodowych, co daje duże szanse na określenie najważniejszych potrzeb, prawidłowe zdefiniowanie celów edukacji finansowej i określenie ich hierarchii, zapobieganie duplikowaniu wielu inicjatyw przez co jest możliwe obniżenie kosztów prowadzonych działań. Efektywności działań sprzyja także wymiana doświadczeń krajowych i międzynarodowych na każdym etapie procesu edukacji finansowej. Propozycja OECD spotkała się z dużym zainteresowaniem zarówno krajów członkowskich, jak i innych. Wiele z nich nie tylko opracowało strategię, lecz także ją wdrożyło, pozostałe są w trakcie opracowywania i wdrażania (OECD 2013). Realizacja idei napotyka jednak na wiele problemów takich np., jak brak zasobów finansowych, problemy z identyfikacją lidera, trudności w uzgodnieniu głównych celów i treści narodowych strategii, integracja wszystkich zainteresowanych stron wokół najważniejszych celów, komunikacja między zainteresowanymi stronami, utrzymanie długoterminowego zaangażowania wszystkich uczestników rozwoju narodowych strategii oraz skuteczność w fazie operacyjnej.

Narodowe strategie skupiają wiele działań i inicjatyw, mogą one jednak stanowić element działań zakrojonych na jeszcze szerszą skalę.

Nie sposób tutaj wymienić wszystkich inicjatyw realizowanych w ramach edukacji finansowej społeczeństw poszczególnych krajów. Warto jednak zwrócić uwagę na aktywnie działające prawie we wszystkich krajach stowarzyszenia inwestorów indywidualnych oraz kluby inwestycyjne wspierające edukację finansową oraz na coraz to nowsze i ciekawsze rozwiązania, jak np. powstała w USA idea tzw. piramidy finansowych umiejętności i podstawowych kompetencji, która zawiera obszary reprezentujące najbardziej wszechstronne standardy finansowego analfabetyzmu. 


\section{Poziom wiedzy finansowej polskiego społeczeństwa oraz problem edukacji finansowej w Polsce}

Niski poziom alfabetyzacji finansowej oraz jego wpływ na rozwój rynku kapitałowego jest problemem aktualnym także w Polsce. O niewystarczającym poziomie alfabetyzacji finansowej polskiego społeczeństwa świadczą zarówno wyniki badań prowadzonych w Polsce (Fundacja Kronenberga i Citi Handlowy 2009; NBP 2013), jak i wyniki badań międzynarodowych (Atkinson i Messy 2012, s. 10, por. tabela 1; OECD 2013, por. rys. 1 i 2). Badania mające na celu określenie poziomu wiedzy finansowej polskiego społeczeństwa przeprowadzone w 2009 roku pokazały, że jest on zdecydowanie niski. Średnia liczba poprawnych odpowiedzi w teście weryfikującym wiedzę finansową i składającym się z 20 pytań wynosiła 8,1 . Wyniki badań przeprowadzonych w 2012 roku $^{1}$ potwierdziły niski i średni poziom wiedzy finansowej u większości Polaków: tylko 28\% Polaków potrafiło poprawnie odpowiedzieć na 13 lub więcej pytań, w relatywnie łatwym teście wiedzy. Niski poziom wiedzy finansowej Polaków wykazany w badaniach przeprowadzonych w 2009 r. i w 2012 r. odnosi się do wiedzy finansowej mierzonej zarówno obiektywnie (test), jak i subiektywnie (samoocena). Wyniki badań prowadzonych na arenie międzynarodowej dodatkowo przedstawiają niewystarczający poziom alfabetyzacji finansowej polskiego społeczeństwa na tle społeczeństw innych krajów, wskazując jednocześnie niekorzystną sytuację także w innych krajach.

Społeczeństwo polskie cechuje brak motywacji do nabywania i pogłębiania wiedzy finansowej oraz poprawy umiejętności finansowych. Wiedza finansowa jest postrzegana jako trudna i nudna, w związku z tym większa część społeczeństwa nie szuka merytorycznych źródeł informacji. Chociaż należy zauważyć, że odnotowano pewne pozytywne zmiany tendencji w tym obszarze: cykliczne badania postaw pokazały, że odsetek osób sięgających po profesjonalne materiały dotyczące finansów osobistych wzrósł z $24 \%$ w 2008 r. do $38 \%$ w 2012 r. (Kaczmar 2013).

Należy także zwrócić uwagę na utratę zaufania do tzw. ekspertów finansowych reprezentujących różne instytucje finansowe, zwłaszcza powiązane z ryzykownymi instrumentami rynku kapitałowego. Największym zaufaniem spośród instytucji finansowych cieszy się Narodowy Bank Polski (Czapiński i Panek 2013).

Poziom wiedzy i umiejętności finansowych przejawia się między innymi w stopniu włączenia finansowego, który także jest niski i nie sprzyja rozwo-

1 Opublikowane w 2013 roku. 
jowi rynku finansowego (w tym kapitałowego). W społeczeństwie polskim można wręcz wyszczególnić tzw. grupy wykluczone finansowo, tzn. takie, które nie korzystają z żadnych usług finansowych, nie wiedzą często jak rozpocząć korzystanie z produktów i usług finansowych, a także nie mają świadomości korzyści wynikających z ofert rynku finansowego.

Brak podstawowej wiedzy finansowej uniemożliwia sprawne zarządzanie finansami domowymi (np. prowadzenie budżetu, planowanie i kontrolowanie wydatków), podejmowanie decyzji o oszczędzaniu², a już zupełnie wyklucza świadome i efektywne inwestowanie ${ }^{3}$ zgromadzonych nadwyżek finansowych (zwłaszcza w ryzykowne instrumenty rynku kapitałowego).

\section{Ry s u n e 3. Ocena własnych inwestycji na rynkach finansowych w latach 2005-2010}

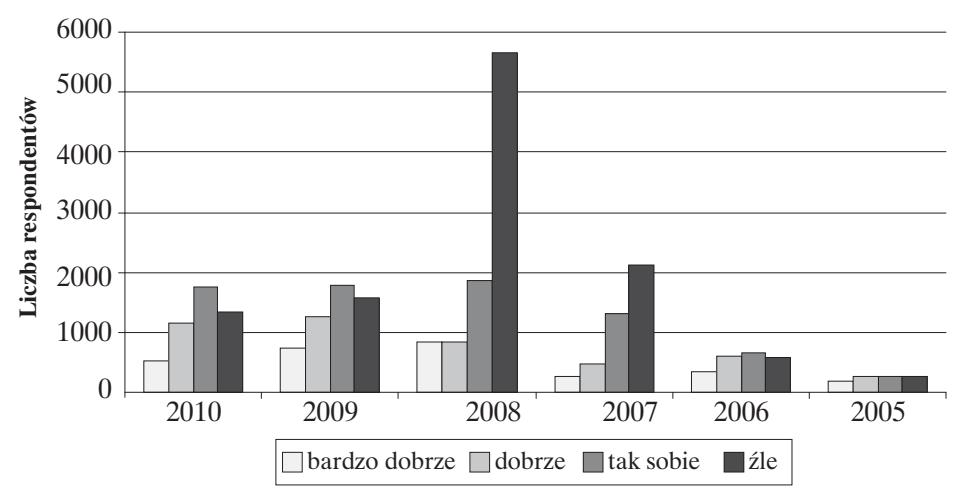

Źródło: opracowanie własne na podstawie sondażu przeprowadzonego na stronie: http://stooq. com (grudzień 2013).

Z cyklicznych badań (Fundacja Kronenberga 2010; 2011; 2012; 2013), mających na celu ocenę postaw Polaków wobec oszczędzania i inwestowania wynika, że ich zdecydowana większość nie toleruje ryzyka (67-73\% respondentów w latach 2008-2012), a nieznaczna ich część deklaruje, że zdecydowało się na rozpoczęcie inwestowania (7\% w 2007 r. i 2010 r., $11 \%$ w 2011 r., 12\% w 2012 r. i 6\% w 2013 r.) - z czego w 2013 r. inwestowanie za pośrednictwem funduszy inwestycyjnych i inwestowanie w nieruchomości zadeklarowało po $2 \%$ respondentów, a inwestowanie na giełdzie w akcje zadeklarował

2 Oszczędzanie w tym miejscu jest rozumiane jako odłożenie nadmiaru środków finansowych, których nie przeznacza się na bieżącą konsumpcję.

3 Inwestowanie rozumiane jest jako aktywne działanie, mające na celu zwiększenie wartości posiadanego kapitału. 
$1 \%$ respondentów. W grupie inwestujących Polaków dominują mężczyźni w wieku od 26 do 50 lat, osiągający wyższe dochody oraz mających wyższe wykształcenie. Jednak wielu $\mathrm{z}$ nich w ograniczonym stopniu stosuje zasady dywersyfikacji portfela inwestycyjnego, a zdecydowana większość badanych (68\% w 2012 r.) przyznała, że ulega negatywnym wpływom psychiki na decyzje inwestycyjne (inklinacje behawioralne). Skutkuje to błędnymi decyzjami inwestycyjnymi i w efekcie niezadowoleniem z poczynionych działań inwestycyjnych.

Brak zadowolenia z wyników inwestycji, w które zaangażowane są własne środki nie zachęca do dalszych działań w tym obszarze, a tym bardziej do zwiększania zaangażowania finansowego w poszczególne produkty rynku finansowego. Stąd też niezbyt imponujący jest udział inwestorów indywidualnych na Giełdzie Papierów Wartościowych, która jest jedną z najważniejszych instytucji rynku kapitałowego w Polsce. Potwierdzają to dane zaprezentowane na rysunkach 4 i 5.

Zmniejszający się udział inwestorów indywidualnych w obrotach akcjami na GPW świadczy o braku wzrastającego zainteresowania produktami rynku kapitałowego ze strony inwestorów indywidualnych. Na taką sytuację wpłynęło z pewnością wiele różnych czynników. Jednak wcześniejsza analiza poziomu alfabetyzacji finansowej polskiego społeczeństwa (zwłaszcza wiedzy

Rysunek 4. Udział inwestorów indywidualnych (w porównaniu z inwestorami instytucjonalnymi i zagranicznymi) w obrotach akcjami na rynku głównym w latach 2002-2012 (w \%)

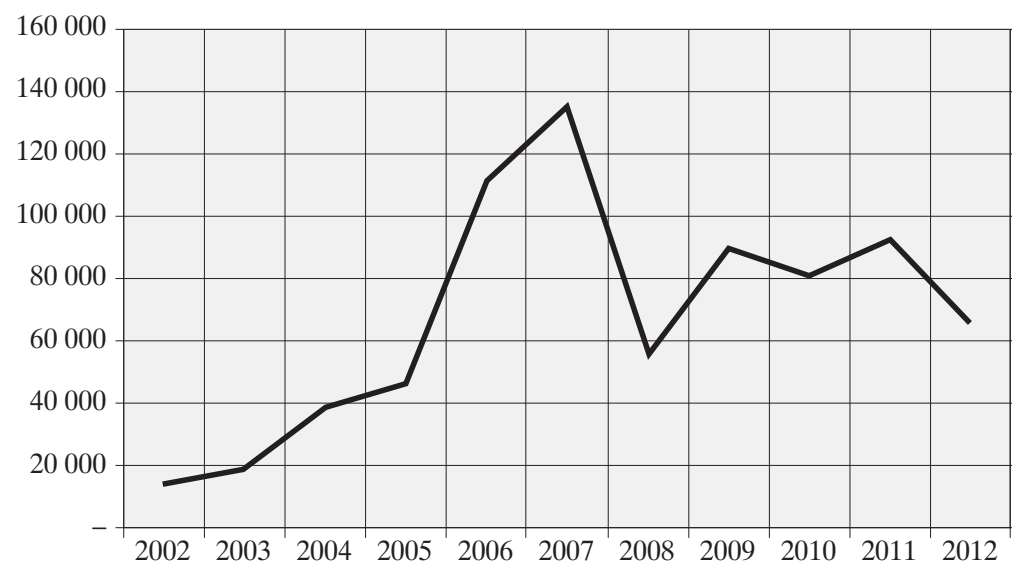

Źródło: opracowanie własne na podstwie danych GPW. 
Rysunek 5. Obroty inwestorów indywidualnych akcjami na rynku głównym w latach 2002-2012 (w mln zl)

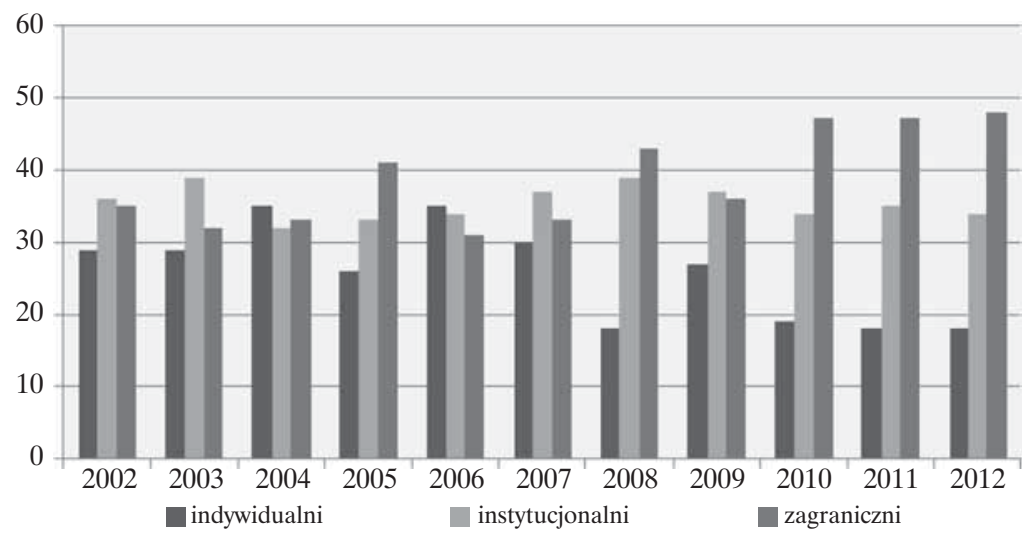

Źródło: opracowanie własne na podstwie danych GPW.

finansowej i postaw finansowych) wskazuje, że to właśnie jej niski poziom jest istotnym czynnikiem ograniczającym rozwój rynku kapitałowego z udziałem inwestorów indywidualnych.

Niezbędna zatem jest efektywna edukacja finansowa społeczeństwa. W Polsce podjętych zostało wiele inicjatyw w tym zakresie, wśród których należy wyszczególnić:

- badania mające na celu określenie poziomu edukacji finansowej polskiego społeczeństwa;

- programy, skierowane do dzieci i młodzieży, np. do dzieci szkół podstawowych (Od Grosika do Złotówki), dla uczniów gimnazjów i szkół średnich (Być Przedsiębiorczym), do młodzieży (Moje Finanse), dla młodzieży ponadgimnazjalnej interesującej się finansami - Olimpiada Wiedzy o Finansach (Banki w Akcji) itp.;

- krajowe kampanie edukacyjne (np. Tydzień dla Oszczędzania) i krajowe programy dla studentów oraz absolwentów planujących rozwinąć własny biznes (np. Business Startup) i wiele innych.

Nie wyklucza się także opracowania i wdrożenia narodowej strategii dla edukacji finansowej. Wiele znaczących instytucji również promuje i rozwija ideę edukacji finansowej w Polsce, przykładowo: Narodowy Bank Polski, Fundacja Kronenberga, Komisja Nadzoru Finansowego, Giełda Papierów Wartościowych, Akademickie Inkubatory Przedsiębiorczości i wiele innych. 
Jednak należy zauważyć, że wszystkie inicjatywy w Polsce nie są wystarczająco skoordynowane i to należy zmienić w pierwszej kolejności.

\section{Wnioski}

Zakres znaczenia poziomu alfabetyzacji finansowej społeczeństwa dla rozwoju rynku kapitałowego (jak również innych segmentów rynku finansowego) jest bardzo szeroki i obejmuje:

- świadome gromadzenie środków pieniężnych poprzez ograniczanie konsumpcji, na rzecz oszczędzania i inwestowania;

- zwiększanie zaangażowania kapitału społeczeństwa w poszczególne instrumenty i usługi rynku finansowego z jednoczesnym wpływem na ich rozwój i ewolucję;

- zmianę poziomu akceptacji ryzyka i zwiększenie zaangażowania w walory ryzykowne;

- zmianę (poprawę) wzorców i postaw finansowych;

- zwiększenie poziomu zaufania do rynków finansowych w tym także w kwestii doradztwa oszczędnościowego i/lub inwestycyjnego, poprzez zrozumienie istoty produktów oferowanych na rynku finansowym oraz poznanie zasad ochrony konsumentów;

- zwiększaniu poziomu włączenia finansowego (integracja finansowa).

Wymienione skutki zwiększania poziomu alfabetyzacji finansowej społeczeństw mogą w różnych aspektach przyczynić się do rozwoju rynku finansowego poprzez:

- zwiększenie kapitalizacji poszczególnych segmentów rynku finansowego, a tym samym zwiększenie skali i przyspieszenie rozwoju produktów i usług (innowacji) finansowych;

- wpływ na poprawę płynności na rynku finansowym;

- pozytywny wpływ na zmienność stóp zwrotu i zmniejszenie tzw. szumu na rynku akcji.

Zatem niewystarczający poziom alfabetyzacji finansowej społeczeństw wielu krajów (w tym Polski) powinien skłonić odpowiedzialne podmioty do podjęcia bardziej zaawansowanych i zakrojonych na szerszą skalę działań w zakresie bezstronnej edukacji finansowej.

Działania w zakresie edukacji finansowej powinny być uporządkowane, spójne i skoordynowane oraz powinny zmierzać w kierunku poprawy zarów- 
no wiedzy, jak i świadomości, umiejętności oraz postaw i zachowań finansowych. Proces edukacji finansowej powinien rozpocząc etap oceny poziomu wiedzy finansowej (ekonomicznej) społeczeństwa wraz z identyfikacją obszarów, w których wiedza ta jest najmniejsza - jako potencjalnych obszarów dla działań edukacyjnych. Z punktu widzenia możliwości rozwoju rynku kapitałowego ten etap jest niezwykle istotny, ponieważ najsłabsze dotychczas - pod względem poziomu alfabetyzacji finansowej - grupy społeczne, w wyniku efektywnej edukacji finansowej, mogą okazać się potencjalnymi uczestnikami tego rynku. Dotyczy to przede wszystkim dzieci, młodzieży i kobiet.

Poszczególne działania edukacyjne powinny być dedykowane konkretnym grupom docelowym z uwzględnieniem najbardziej efektywnych kanałów dystrybucji. Promowane powinny być najbardziej efektywne, w tym nowe media w edukacji finansowej.

Coraz częściej zwraca się uwagę na konieczność szeroko rozumianej koordynacji działań w zakresie podnoszenia poziomu alfabetyzacji, w tym wiedzy finansowej. Oznacza to, że poszczególne inicjatywy powinny być koordynowane na szczeblu krajowym i w miarę możliwości międzynarodowym. Wzmocnienie współpracy pomiędzy np. European Commision (EC) a innymi instytucjami międzynarodowymi powinno ułatwić promowanie wśród rządów poszczególnych krajów edukacji finansowej z możliwością osiągnięcia efektu synergii oraz wyeliminowania dublowania działań. Koordynacja działań w regionie umożliwia wspólne unijne badania $\mathrm{w}$ zakresie poziomu alfabetyzacji społeczeństw poszczególnych krajów, tworzenie wspólnych programów edukacji finansowej dedykowanych poszczególnym grupom docelowym, wymianę doświadczeń w zakresie wdrażania programów, monitorowanie postępu w różnych krajach i szereg innych inicjatyw w obszarze edukacji finansowej.

Spełnienie postulatu koordynacji działań umożliwiają narodowe strategie dla edukacji finansowej, których idea zakłada szeroko rozumianą współpracę na każdym etapie opracowywania i wdrażania strategii ze szczególnym uwzględnieniem partnerstwa podmiotów z sektora publicznego i prywatnego.

W wielu krajach, w których do tej pory nie wdrożono narodowej strategii edukacji finansowej (w tym w Polsce) nie wyklucza się wprowadzenia takiego rozwiązania. Organizacje międzynarodowe (np. OECD, EC) w sposób ciągły promują ideę narodowych strategii i nakłaniają poszczególne kraje do ich opracowywania. W wielu przypadkach podjęte zostały nawet kroki w kierunku opracowania stosownego dokumentu. Jednak niezależnie od tego czy NS została opracowana i wdrożona, czy też nie, w każdym kraju prowadzonych jest wiele inicjatyw w obszarze edukacji finansowej. Idea Narodowych Strategii nie wyklucza możliwości efektywnych działań w ramach procesu edukacji 
finansowej prowadzonych poza nimi w ramach szerokiej polityki edukacji finansowej.

\section{Bibliografia}

Atkinson, A. (2007). Financial capability amongst adults with literacy and numeracy needs, Personal Finance Research Centre. Bristol UK: University of Bristol.

Atkinson, A. i Messy, F. (2012). Measuring Financial Literacy: Results of the OECD/International Network on Financial Education (INFE) Pilot Study, OECD Working Papers on Finance, Insurance and Private Pensions, No. 15, OECD Publishing. Pobrano: http:// dx.doi.org/10.1787/5k9csfs90fr4-en.

Berggren, J. i Gonzalez, R. (2010). Gender difference in financial decision making - A quantitative study of risk aversion and overconfidence between the genders. Umeå Sweden: Umeå University.

Calvet, L.E., Campbell J.Y. i Sodini, P. (2009). Measuring the Financial Sophistication of Households, American Economic Review, 99(2).

Caratelli, M. i Ricci, O. (2012). The relationship between everyday practices and financial literacy, An empirical analysis, Proceedings of ASBBS, 19(1).

Christiansen, Ch., Joensen, S.J. i Rangvid, J. (2008). Are economists more likely to hold stocks?, Review of Finance, 12(3).

Czapiński, J. i Panek, T. (red.) (2013). Diagnoza Społeczna 2013. Warunki i jakość życia Polaków. Raport. Rada Monitoringu Społecznego, Warszawa.

Foucault, T., Sraer, D. i Thesmar, D.J. (2011). Individual Investors and Volatility, The Journal of Finance, LXVI, 4.

Fundacja Kronenberga i Citi Handlowy (2009). Stan wiedzy finansowej Polaków. Raport z badań ilościowych. Fundacja Kronenberga I Citi Handlowy, Dom Badawczy Maison, Warszawa, wrzesień.

Fundacja Kronenberga (2010/2011/2012/2013). Postawy Polaków wobec oszczędzania - raport Fundacji Kronenberga przy Citi Handlowy i Komisji Nadzoru Finansowego. Pentor (2010/2011), TNS Polska (2012/2013).

Gardeva, A. i Rhyne, E. (2011). Opportunities and Obstacles to Financial Inclusion. Survey Report, Center for Financial Inclusion. Pobrano z: http://centerforfinancialinclusionblog. files.wordpress.com/2011/07/opportunities-and-obstacles-to-financial-inclusion_110708_ final.pdf.

Kaczmar, K. (2013). Kompetencje finansowe Polaków w gospodarce rynkowej, Infos, 5(142), Biuro Analiz Sejmowych, Warszawa.

Lusardi, A. (2008). Financial Literacy: An Essential Tool for Informed Consumer Choice?, Working paper, No. UCC08-11, Joint Center for Housing Studies, Harvard University, Cambridge, Massachusetts,

Mandell, L. i Klein-Schmid L. (2009). The Impact of Financial Literacy Education on Subsequent Financial Behavior, Journal of Financial Counseling and Planning, 20(1).

Nannyanzi, S. (2009). Financial Knowledge, Locus of Control, Cultural Values and Financial Behaviour among new vision employees. Pobrano z: http://www.mubs.ac.ug/docs/ masters/acc_fin/Financial $\% 20$ knowledge, $\% 201$ cus $\% 20 \mathrm{of} \% 20$ control, $\% 20$ cultural $\% 20 \%$ 20Values\%20and\%20financial\%20behaviour.pdf (grudzień 2013). 
NBP (2013). Panorama działań edukacyjnych NBP i najnowsze wyniki badan świadomości ekonomicznej Polaków. Konferencja pn. „Dostępne Finanse 2013”, Warszawa: NBP.

OECD INFE (2011). Measuring Financial Literacy: Core Questionnaire in Measuring Financial Literacy: Questionnaire and Guidance Notes for conducting an Internationally Comparable Survey of Financial literacy. Paris: OECD.

OECD (2005). Recommendation on Principles and Good Practices for Financial Education and Awareness, Recommendation of the Council, Annex.

OECD (2008). First Meeting of The Expert Group on Financial Education, Report, Brussels, European Commission.

OECD (2009). Financial Literacy and Consumer Protection: Overlooked Aspects of the Crisis. OECD. Pobrano z: http://www.oecd.org/finance/financial-markets/43138294.pdf.

OECD (2013a). Women and Financial Literacy, OECD/INFE Evidence, Surveys and Policy Responces.

OECD (2013b). Elektroniczna baza danych OECD nt. edukacji finansowej.

OECD/INFE (2013). Current status of national strategies for financial education, OECD/ INFE Comparative Analysis and Relevant Practices, June.

Rooij, M., Lusardi, A. i Alessie, R. (2007). Financial literacy and stock market participation, Journal of Financial Economics, 101(2011).

Spataro, L. i Corsini, L. (2013). Endogenous financial literacy, saving and stock market participation, MPRA, Paper No. 44342, posted 13. Pobrano z: http://mpra.ub.uni-muenchen. de/44342/1/MPRA_paper_44342.pdf. 



\section{CZĘŚĆ II}

MODELOWANIE ZJAWISK NA RYNKU KAPITAŁOWYM W WARUNKACH NIEPEWNOŚCI I RYZYKA 



\title{
Rozdział VIII
}

\section{ALOJZY Z. NOWAK*, TADEUSZ WINKLER-DREWS** \\ Ryzyko rynku akcji międzynarodowych rynków giełdowych}

\begin{abstract}
Streszczenie
W artykule badano realne stopy zwrotu benchmarków giełd międzynarodowych: NYSE, LSE, Euronext, Deutsche Börse, Tokyo SE w okresie 1950-2012. Przeanalizowano dynamikę ryzyka względnego realnych stóp zwrotu benchmarków w okresach 1-30 lat.
\end{abstract}

Słowa kluczowe: rynki finansowe, giełda, ryzyko finansowe.

\begin{abstract}
The paper examine real rate of return of benchmarks of the top five leading stock exchanges: NYSE, LSE, Euronext, Deutsche Börse, Tokyo SE over 1950-2012. On analyze dynamic of unitized risk values of real rates of return of stocks index for holding periods 1-30 years.
\end{abstract}

Keywords: financial market, stock exchange, financial risk.

\section{Wstęp}

W ciągu ostatnich trzech dekad rynki finansowe doznały bezprecedensowej transformacji, której pierwsze symptomy można było zauważyć w końcu lat siedemdziesiątych XX w. Formalnym przejawem transformacji rynków finansowych w latach osiemdziesiątych było wprowadzenie deregulacji. Skutkami tego procesu była integracja rynków finansowych przyczyniająca się do nasilającej ich konkurencyjności (skutkującej sukcesywnym pojawianiem się innowacji finanso-

* Prof. dr hab. Alojzy Z. Nowak - Katedra Gospodarki Narodowej, Wydział Zarządzania, Uniwersytet Warszawski; e-mail: anowak@wz.uw.edu.pl.

** Dr hab., prof. ALK Tadeusz Winkler-Drews - Akademia Leona Koźmińskiego wWarszawie; e-mail: tadeusz@alk.edu.pl. 
wych). Dynamiczny rozwój technologii informatycznych i telekomunikacyjnych w latach dziewięćdziesiątych przyczynił się do liberalizacji i umiędzynarodowienia rynków finansowych, co doprowadziło do ich globalizacji, czego zaś skutkiem jest zwiększenie rozmiaru rynków finansowych i totalna ich integracja. Koniec lat dziewięćdziesiątych charakteryzował się również dynamicznym rozwojem inwestycji transgranicznych, głównie pomiędzy USA a Europą Zachodnią i w mniejszym stopniu Japonią, co zwiększyło skalę zjawiska. W ostatnich latach na światowych rynkach giełdowych dochodziło do potężnych procesów konsolidacyjnych (największe giełdy przejmowały mniejsze). W konsekwencji obrót giełdowy stał się bardziej skoncentrowany. W 2011 r. 75\% światowych obrotów akcjami dokonywanych było na kilku największych giełdach (NYSE, LSE, Euronext, Tokyo SE) (www.world-exchange.org). Efektem omawianych procesów jest globalna skala skutków wydarzeń i zjawisk na poszczególnych rynkach, zwiększająca poziom ryzyka rynkowego. W literaturze przedmiotu zagadnienie ryzyka na rynkach giełdowych było analizowane wieloaspektowo. W niniejszym artykule przedstawiamy wyniki badań kształtowania się poziomu ryzyka rynku akcji pięciu wiodących giełd: NYSE, LSE, Euronext, Deutsche Börse, Tokyo SE w okresie 1950-2012. Przyjętą miarą ryzyka jest wielkość odchylenia standardowego rozkładu realnych stóp zwrotu przypadająca na jednostkową stopę zwrotu. Poziomy ryzyka zostały wyznaczone dla horyzontów inwestycyjnych od 1roku do 30 lat. Do badań użyto miesięcznych danych bazy Global Financial Data.

\section{Rynek amerykański}

Wynikiem wzmocnienia gospodarki amerykańskiej w okresie II wojny światowej była znaczna przewaga ekonomiczna Stanów Zjednoczonych nad pozostałymi państwami kapitalistycznymi w okresie powojennym. Wyścig zbrojeń wywołany zimną wojną oraz wybuch wojny koreańskiej dały nowy impuls (boom koreański) - w latach 1950-1953 (produkcja przemysłowa USA wzrosła o 41\%). Zakończenie wojny koreańskiej spowodowało spadek wydatków budżetowych, co wywołało krótkotrwałą recesję (1953-1954). Wzrost inflacji w USA przyczynił się do kolejnej recesji (1957-1958). Stymulatorem wysokiego tempa wzrostu gospodarczego USA w latach pięćdziesiątych była rosnąca produkcja przemysłowa. W latach sześćdziesiątych napęd gospodarki stanowiły zaś nakłady na badania naukowe i wdrożeniowe w przemyśle, stymulowane wyścigiem gospodarczym związanym z wyścigiem zbrojeń. Nakłady na: wdrażanie programu „Nowa Ekonomika”, eksplorację kosmosu czy wojnę wietnamską spowodowały deficyt budżetowy oraz wzrost inflacji. Od 1969 r. 
głównym celem była walka z inflacją - odejście od keynesizmu na rzecz monetaryzmu, jednak działania te nie dały efektów i w 1970 r. zaczęła się stagflacja. W okresie 1950-1973 gospodarka amerykańska rozwijała się w tempie: PKB $3,9 \%$; produkcja przemysłowa $5,3 \%$; inflacja $2,7 \%$. Pierwszy kryzys naftowy (1974-1975) spowodował spowolnienie dynamiki gospodarki; wzrost bezrobocia i inflacji oraz wywołał stagflację. Podjęto więc walkę z recesją w duchu monetarystycznym. W 1977 r. prezydent, Jimmy Carter, zapoczątkował szereg programów o charakterze socjalnym, co tylko pogorszyło sytuację (w 1980 inflacja wyniosła 13,5\%). W 1981 r. Ronald Reagan wprowadził deregulację, zwiększono wydatki na zbrojenia „Gwiezdne wojny” (inflacja spadła do 6,2\%). W 1982 r. spadek cen ropy obniży inflację do 3,2\%, co spowolniło wzrost gospodarczy. Zapoczątkowane w 1983 r. przyspieszenie gospodarcze utrzymało się - w 1990 r. PKB rósł średnio o 3,4\%. Innowacyjność wpłynęła na wzrost eksportu, ale nie zatrzymało to wysokiego deficytu płatniczego USA, które były największym dłużnikiem świata. Do tego dochodził ogromny dług wewnętrzny - w 1986 r. deficyt wynosił 200 mld USD (głównie na skutek programu „Gwiezdne wojny”). W 1974-1990 gospodarka amerykańska rozwijała się w tempie: PKB 2,6\%; produkcja przemysłowa 2,5\%; inflacja 6,7\%. Wydatki na zbrojną interwencję w Kuwejcie w latach 1990-1991 osłabiły koniunkturę. W $2001 \mathrm{r}$. rozpoczęła się zbrojna interwencja w Afganistanie, a w okresie 2003-2005 wojna w Iraku (szacowana na 802 mld USD), które spowolniły gospodarkę. W 2008 r. rozpoczął się kryzys subprime. Interpretację rynkową omawianych powyżej zjawisk gospodarczych prezentuje rysunek 1 .

Pomimo wydatków na wyścig zbrojeń, eksplorację kosmosu, programy socjalne, wojnę w Wietnamie, zainicjowany koniunkturą wojny koreańskiej wzrostowy trend gospodarki amerykańskiej utrzymał się do początków lat siedemdziesiątych, co znajduje potwierdzenie w koniunkturze giełdy nowojorskiej. Bardzo niekorzystne dla gospodarki amerykańskiej skutki obu kryzysów energetycznych oraz wydatki na „Gwiezdne wojny” nie zmieniły wzrostowego trendu giełdowego w latach 1973-1984. Rozwój sektora IT zdynamizował rozwój gospodarki amerykańskiej na przełomie lat osiemdziesiątych i dziewięćdziesiątych, co przełożyło się również na dynamikę koniunktury giełdowej w okresie 1985-1994. Odwrócenie dynamicznego trendu wzrostowego nastąpiło w 1999 r. w wyniku kryzysu branży MTM, kolejny trend wzrostowy po 2002 r. został odwrócony na skutek kryzysu subprime. Charakterystyki rozkładów realnych stóp zwrotu indeksu DJIA prezentuje tabela 1.

Wartości oczekiwanych stóp zwrotu dla 30-letniego horyzontu są ponad dwukrotnie mniejsze od wartości oczekiwanych stóp zwrotu dla horyzontu jednorocznego. Relacje wartości odchylenia standardowego dla analo- 
gicznych horyzontów są ponad siedmiokrotne. Wartości ryzyka względnego realnych oczekiwanych stóp zwrotu indeksu DJIA w zależności od długości horyzontu inwestycyjnego ilustruje rysunek 2.

Ry s u e k 1. Wartości indeksu DJIA i inflacji USA (1950-2012)

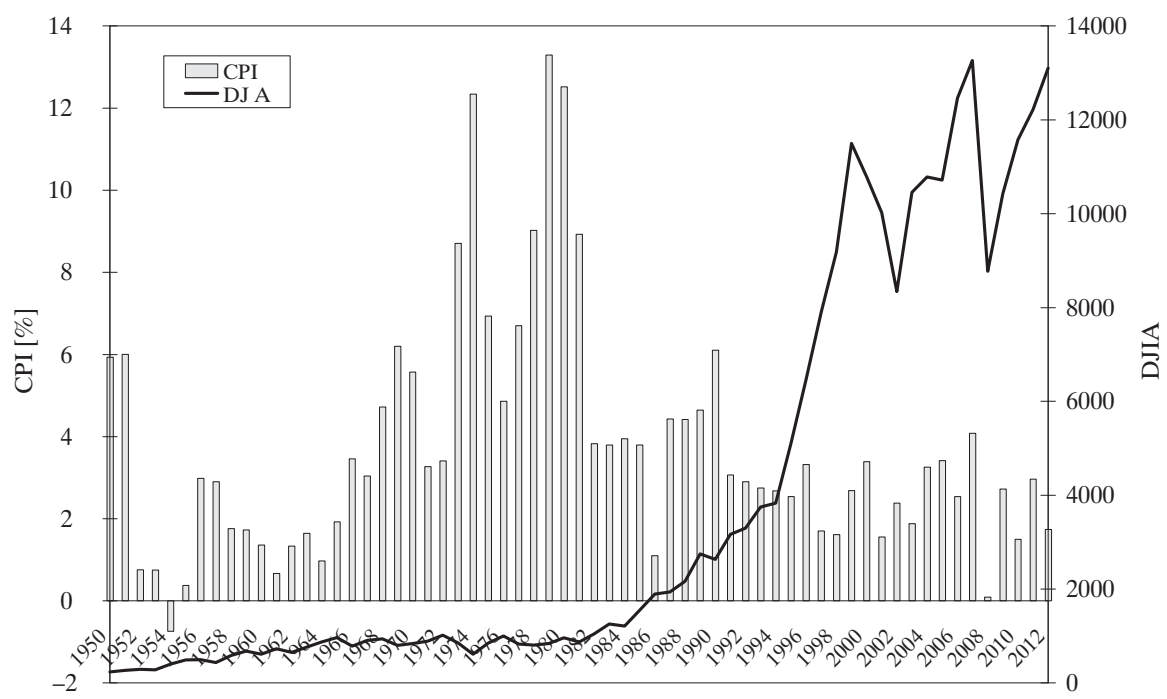

Źródło: opracowanie własne na podstawie: Global Financial Data.

\section{Ry s u n e $k$ 2. Wartości ryzyka względnego indeksu DJIA}

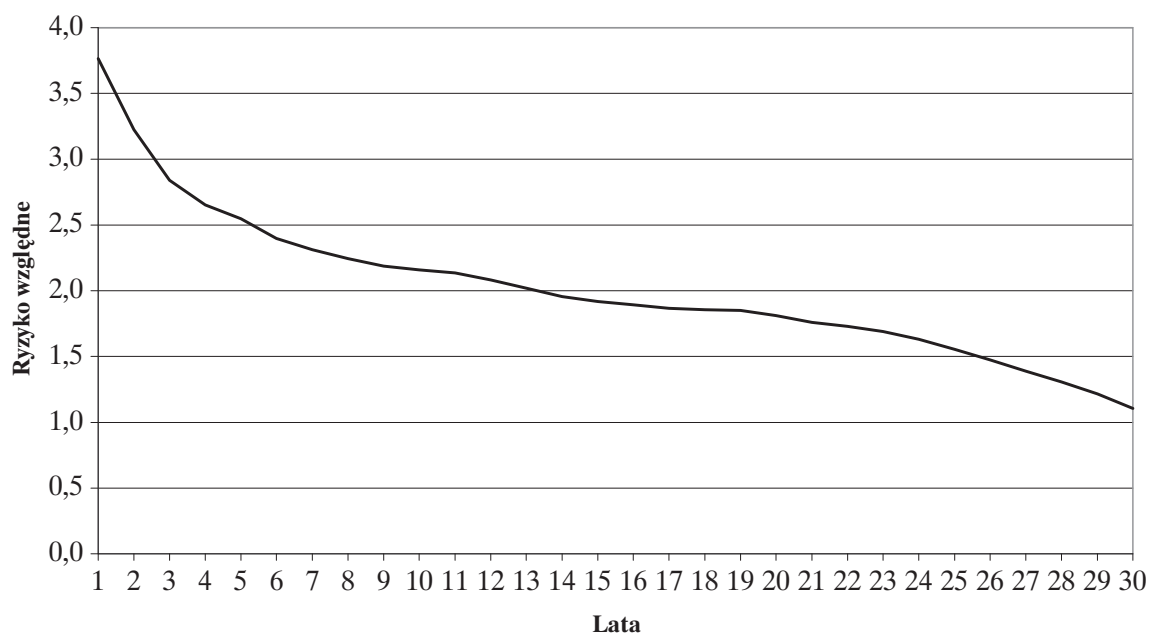

Źródło: opracowanie własne na podstawie: Global Financial Data. 
Ta be la 1. Charakterystyki rozkładów realnych stóp zwrotu indeksu DJIA

\begin{tabular}{|c|c|c|c|c|c|c|c|}
\hline \multirow{2}{*}{$\begin{array}{l}\text { Horyzont } \\
\text { inwesty- } \\
\text { cyjny } \\
\text { (lata) }\end{array}$} & \multicolumn{3}{|c|}{ Stopa zwrotu } & \multirow{2}{*}{$\begin{array}{c}\text { Odchylenie } \\
\text { standar- } \\
\text { dowe } \\
(\%)\end{array}$} & \multirow[b]{2}{*}{ Kurtoza } & \multirow[b]{2}{*}{ Skośność } & \multirow[b]{2}{*}{$\begin{array}{c}\text { Ilość } \\
\text { obserwacj }\end{array}$} \\
\hline & $\begin{array}{c}\underset{(\%)}{\operatorname{minimum}} \\
\end{array}$ & $\begin{array}{c}\text { maksi- } \\
\text { mum } \\
(\%)\end{array}$ & \begin{tabular}{|c|} 
wartość \\
oczekiwana \\
$(\%)$
\end{tabular} & & & & \\
\hline 1 & $-42,67$ & 46,72 & 4,33 & 16,30 & $-0,130$ & 0,040 & 745 \\
\hline 2 & $-29,66$ & 37,28 & 3,60 & 11,61 & $-0,013$ & 0,131 & 733 \\
\hline 3 & $-18,16$ & 28,25 & 3,29 & 9,34 & $-0,450$ & 0,184 & 721 \\
\hline 4 & $-13,94$ & 22,91 & 3,11 & 8,25 & $-0,768$ & 0,216 & 709 \\
\hline 5 & $-12,08$ & 22,20 & 3,06 & 7,79 & $-0,756$ & 0,175 & 697 \\
\hline 6 & $-13,06$ & 18,20 & 3,00 & 7,19 & $-0,856$ & 0,005 & 685 \\
\hline 7 & $-11,19$ & 16,64 & 2,92 & 6,75 & $-1,035$ & $-0,051$ & 673 \\
\hline 8 & $-9,97$ & 15,14 & 2,87 & 6,44 & $-1,102$ & $-0,159$ & 661 \\
\hline 9 & $-9,99$ & 14,89 & 2,85 & 6,23 & $-1,051$ & $-0,292$ & 649 \\
\hline 10 & $-9,45$ & 13,17 & 2,77 & 5,98 & $-1,141$ & $-0,304$ & 637 \\
\hline 11 & $-8,45$ & 12,89 & 2,72 & 5,81 & $-1,209$ & $-0,265$ & 625 \\
\hline 12 & $-7,74$ & 12,47 & 2,70 & 5,62 & $-1,202$ & $-0,236$ & 613 \\
\hline 13 & $-8,13$ & 12,79 & 2,71 & 5,47 & $-1,076$ & $-0,233$ & 601 \\
\hline 14 & $-7,74$ & 12,97 & 2,71 & 5,30 & $-0,985$ & $-0,188$ & 589 \\
\hline 15 & $-7,58$ & 12,91 & 2,68 & 5,14 & $-0,929$ & $-0,138$ & 577 \\
\hline 16 & $-7,39$ & 12,48 & 2,62 & 4,96 & $-0,886$ & $-0,117$ & 565 \\
\hline 17 & $-6,97$ & 12,92 & 2,56 & 4,78 & $-0,914$ & $-0,081$ & 553 \\
\hline 18 & $-6,36$ & 11,71 & 2,48 & 4,60 & $-1,014$ & $-0,043$ & 541 \\
\hline 19 & $-5,25$ & 10,93 & 2,39 & 4,42 & $-1,122$ & $-0,004$ & 529 \\
\hline 20 & $-4,84$ & 9,96 & 2,32 & 4,20 & $-1,214$ & 0,015 & 517 \\
\hline 21 & $-4,84$ & 8,95 & 2,28 & 4,01 & $-1,326$ & 0,026 & 505 \\
\hline 22 & $-4,23$ & 8,94 & 2,22 & 3,84 & $-1,385$ & 0,085 & 493 \\
\hline 23 & $-4,36$ & 8,53 & 2,16 & 3,65 & $-1,403$ & 0,102 & 481 \\
\hline 24 & $-3,03$ & 8,20 & 2,11 & 3,44 & $-1,441$ & 0,138 & 469 \\
\hline 25 & $-3,05$ & 8,50 & 2,09 & 3,25 & $-1,381$ & 0,167 & 457 \\
\hline 26 & $-3,12$ & 7,95 & 2,09 & 3,08 & $-1,423$ & 0,174 & 445 \\
\hline 27 & $-2,70$ & 7,05 & 2,06 & 2,86 & $-1,521$ & 0,197 & 433 \\
\hline 28 & $-2,01$ & 6,70 & 2,02 & 2,64 & $-1,495$ & 0,270 & 421 \\
\hline 29 & $-1,67$ & 6,71 & 1,99 & 2,42 & $-1,403$ & 0,307 & 409 \\
\hline 30 & $-1,15$ & 6,62 & 1,98 & 2,19 & $-1,296$ & 0,398 & 397 \\
\hline
\end{tabular}

Źródło: opracowanie własne na podstawie: Global Financial Data. 
Ta be la 2. Dynamika ryzyka względnego indeksu DJIA

\begin{tabular}{|l|c|c|r|r|r|r|c|}
\hline \multicolumn{1}{|c|}{ Horyzont inwestycyjny (lata) } & $\mathbf{1}$ & $\mathbf{5}$ & \multicolumn{1}{|c|}{$\mathbf{1 0}$} & \multicolumn{1}{|c|}{$\mathbf{5}$} & \multicolumn{1}{c|}{$\mathbf{2 0}$} & \multicolumn{1}{c|}{$\mathbf{2 5}$} & $\mathbf{3 0}$ \\
\hline Ryzyko względne indeksu DJIA & 3,77 & 2,54 & 2,16 & 1,92 & 1,81 & 1,56 & 1,11 \\
\hline Zmiana (\%) & & 32,45 & 42,58 & 48,98 & 51,90 & 58,65 & 70,5 \\
\hline
\end{tabular}

Źródło: opracowanie własne na podstawie: Global Financial Data.

Dynamikę ryzyka względnego realnych stóp zwrotu indeksu DJIA prezentuje tabela 2 .

Większa dynamika redukcji ryzyka względnego realnych stóp zwrotu benchmarku rynku amerykańskiego charakteryzuje krótkie horyzonty inwestycyjne. Dla horyzontów o długości 5-20 lat dynamika redukcji ryzyka względnego indeksu DJIA maleje. Impuls wzrostowy analizowanego parametru pojawia się na przestrzeni horyzontów o długościach 20-30 lat.

\section{Rynek brytyjski}

Pomimo że Wielka Brytania była jednym z trzech państw decydujących o rozstrzygnięciu II wojny światowej, gospodarczo wyszła z niej mocno osłabiona. Odbudowa gospodarki była możliwa dzięki pomocy USA. W latach 1945-1951 wprowadzono program nacjonalizacyjny. Ukierunkowana na kolonie gospodarka brytyjska nie była gotowa do pełnego wykorzystania proeksportowej koniunktury na surowce dla przemysłu zbrojeniowego USA w okresie wojny koreańskiej. Wybuch wojny koreańskiej dał impuls wzrostowy, przejściowo zakłócony w 1952 r. (PKB - 0,2\%, a inflacja 9,6\%). Porażka w konflikcie sueskim w 1956 r. spowodowała szybki rozpad imperium kolonialnego. Konserwatywna struktura gospodarki oraz mniejsze, w porównaniu z innymi krajami, nakłady na R\&D doprowadziły w 1959 r. do utraty pozycji europejskiego lidera pod względem PKB na rzecz RFN. Efektem programu budowania „społeczeństwa dobrobytu” oraz w 1964 r. kolejnej nacjonalizacji niektórych gałęzi przemysłu była kilkunastoprocentowa dewaluacja funta w 1967 r., co ożywiło eksport, ale również pobudziło inflację osiagającą w 1971 r. wartość 9,4\%. Głównym stymulatorem gospodarki brytyjskiej był, zgodny z zasadami keynesizmu, interwencjonizm państwowy. Wynikiem zwiększania nakładów na badania naukowe i wdrożeniowe od połowy lat sześćdziesiątych była malejąca luka technologiczna między USA a Wielką Brytanią, jednak ubocznym skutkiem był wzrost inflacji, której apogeum (24\%) przypadło na 1975 r. Eksploatacja własnych zasobów ropy spowodo- 
wała samowystarczalność zapotrzebowania na ropę, co w 1976 r. poskutkowało spadkiem inflacji (8\%), po czym przez kolejne trzy lata poziom inflacji ustalił się na poziomie kilkunastu procent. W 1979 r. rządy objęli konserwatyści, wprowadzając neoliberalizm monetarny (thatcheryzm) mający na celu restrukturyzacje przemysłu, ustabilizowanie inflacji, wzmocnienie waluty. Nadejście drugiego kryzysu energetycznego udaremniło reformowanie gospodarki, wywołując w latach 1980-1981 największe spośród krajów rozwiniętych załamanie gospodarcze (PKB -2\%). Konsekwencją wprowadzanych reform był 3,5\% wzrost PKB oraz inflacja do 5\% w 1982 r. W 1983 r. nastąpił znaczny wzrost obrotów międzynarodowych, a w 1986 r. cena ropy wróciła do poziomu przed kryzysem. W latach 1974-1990 gospodarka brytyjska rozwijała się w tempie $1,9 \%$. W dekadzie lat dziewięćdziesiątych XX w. Anglia rozwijała się stabilnie, jednak w pierwszej dekadzie XXI w. rozwój został zakłócony kryzysem subprime (2008 r.). Rynkową interpretację opisanych procesów ekonomicznych prezentuje rysunek 3.

W latach 1950-1973 londyński rynek akcji znajdował się w umiarkowanym trendzie wzrostowym. Rosnąca amplituda naprzemiennych fluktuacji benchmarku LSE wskazuje, że w omawianym okresie rozwój gospodarki brytyjskiej nie dokonywał się bez trudności. Zachowanie rynku giełdowego w latach

\section{Ry s u n e k. Wartości indeksu FTSE i inflacji Wielkiej Brytanii (1950-2012)}

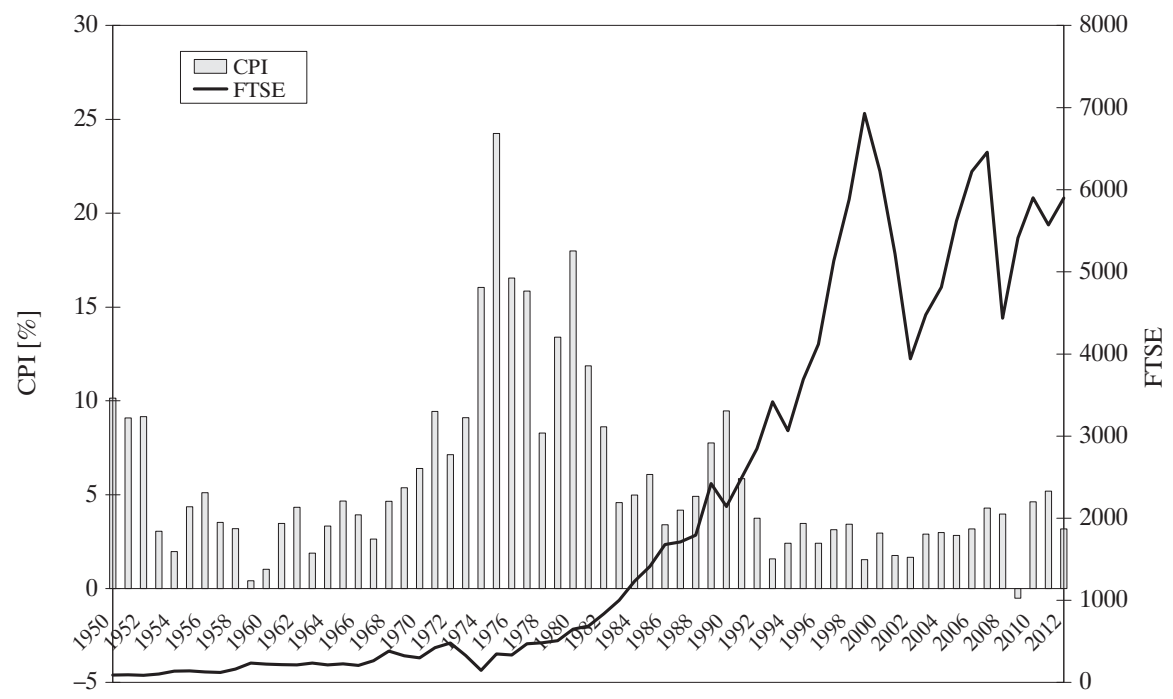

Źródło: opracowanie własne na podstawie: Global Financial Data. 
1950-1955 było adekwatne do dość stabilnego 3\% wzrostu PKB w tym okresie. Porażka w konflikcie sueskim (1956 r.) zainicjowała dziesięcioletni okres większych odchyleń indeksu od linii trendu. Na dewaluację funta (1967 r.) wywołującą sukcesywny wzrost inflacji, a następnie stagflację w wyniku pierwszego kryzysu energetycznego londyńska giełda zareagowała jeszcze większą dynamiką głównego indeksu. Eksploatacja podmorskich złóż ropy, łagodząca skutki pierwszego kryzysu energetycznego, oraz tatcheryzm, osłabiający skutki drugiego kryzysu energetycznego, w dużej mierze przyczyniły się do nieliniowego wzrostowego trendu benchmarku giełdy londyńskiej w latach 1974-1989. W okresie 1990-2012 indeks FTSE charakteryzowały duże amplitudy fluktuacji wokół silnego trendu wzrostowego; punkty zwrotne wyznaczały zjawiska globalne - kryzys MTM w 2000 r. oraz kryzys subprime (2006 r.). Charakterystyki rozkładów realnych stop zwrotu indeksu FTSE prezentuje tabela 3 .

Wartości oczekiwanych stóp zwrotu dla 30-letniego horyzontu są ponad 1,5-krotnie mniejsze od wartości oczekiwanych stóp zwrotu dla horyzontu jednorocznego. Relacje wartości odchylenia standardowego dla analogicznych horyzontów są ponad dwunastokrotne. Wartości ryzyka względnego realnych oczekiwanych stóp zwrotu indeksu FTSE w zależności od długości horyzontu inwestycyjnego ilustruje rysunek 4.

\section{Ry u n e 4. Wartości ryzyka względnego indeksu FTSE}

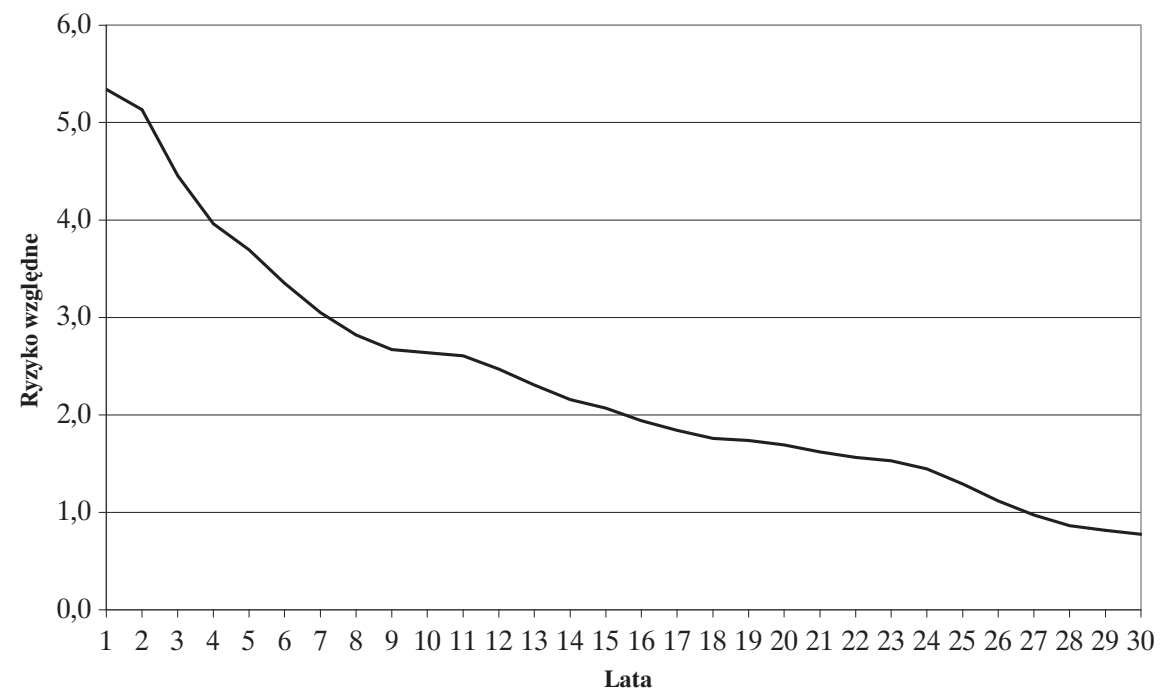

Źródło: opracowanie własne na podstawie: Global Financial Data. 
Ta be la 3. Charakterystyki rozkładów realnych stóp zwrotu indeksu FTSE

\begin{tabular}{|c|c|c|c|c|c|c|c|}
\hline \multirow{2}{*}{$\begin{array}{c}\text { Horyzont } \\
\text { inwesty- } \\
\text { cyjny } \\
\text { (lata) }\end{array}$} & \multicolumn{3}{|c|}{ Stopa zwrotu } & \multirow{2}{*}{$\begin{array}{c}\text { Odchylenie } \\
\text { standar- } \\
\text { dowe } \\
(\%)\end{array}$} & \multirow[b]{2}{*}{ Kurtoza } & \multirow[b]{2}{*}{ Skośność } & \multirow[b]{2}{*}{$\begin{array}{c}\text { Ilośćć } \\
\text { obserwacji }\end{array}$} \\
\hline & $\begin{array}{c}\underset{(\%)}{\operatorname{minimum}} \\
\end{array}$ & $\begin{array}{c}\text { maksi- } \\
\text { mum } \\
(\%)\end{array}$ & $\begin{array}{c}\text { wartość } \\
\text { oczekiwana } \\
(\%)\end{array}$ & & & & \\
\hline 1 & $-65,32$ & 89,06 & 3,56 & 19,02 & 1,260 & $-0,040$ & 745 \\
\hline 2 & $-52,03$ & 40,04 & 2,57 & 13,19 & 1,320 & $-0,462$ & 733 \\
\hline 3 & $-37,52$ & 30,37 & 2,34 & 10,43 & 0,948 & $-0,595$ & 721 \\
\hline 4 & $-25,41$ & 22,90 & 2,14 & 8,48 & 0,487 & $-0,571$ & 709 \\
\hline 5 & $-22,87$ & 23,70 & 2,03 & 7,50 & 0,400 & $-0,500$ & 697 \\
\hline 6 & $-22,24$ & 21,61 & 2,01 & 6,74 & 0,369 & $-0,536$ & 685 \\
\hline 7 & $-16,45$ & 16,70 & 2,02 & 6,16 & $-0,007$ & $-0,451$ & 673 \\
\hline 8 & $-13,91$ & 14,20 & 2,01 & 5,67 & $-0,221$ & $-0,476$ & 661 \\
\hline 9 & $-11,72$ & 11,60 & 2,00 & 5,34 & $-0,557$ & $-0,527$ & 649 \\
\hline 10 & $-10,64$ & 11,48 & 1,93 & 5,09 & $-0,891$ & $-0,453$ & 637 \\
\hline 11 & $-10,68$ & 12,23 & 1,85 & 4,82 & $-0,964$ & $-0,393$ & 625 \\
\hline 12 & $-9,22$ & 11,55 & 1,83 & 4,52 & $-1,030$ & $-0,313$ & 613 \\
\hline 13 & $-8,85$ & 11,90 & 1,86 & 4,29 & $-0,959$ & $-0,297$ & 601 \\
\hline 14 & $-8,68$ & 9,83 & 1,89 & 4,08 & $-0,921$ & $-0,282$ & 589 \\
\hline 15 & $-8,55$ & 10,53 & 1,90 & 3,93 & $-0,907$ & $-0,148$ & 577 \\
\hline 16 & $-6,48$ & 9,50 & 1,92 & 3,73 & $-0,906$ & $-0,052$ & 565 \\
\hline 17 & $-5,75$ & 9,29 & 1,92 & 3,54 & $-0,798$ & 0,069 & 553 \\
\hline 18 & $-4,28$ & 9,16 & 1,92 & 3,38 & $-0,772$ & 0,143 & 541 \\
\hline 19 & $-4,72$ & 9,12 & 1,88 & 3,27 & $-0,786$ & 0,189 & 529 \\
\hline 20 & $-4,65$ & 8,51 & 1,85 & 3,13 & $-0,826$ & 0,162 & 517 \\
\hline 21 & $-3,89$ & 8,26 & 1,82 & 2,95 & $-0,831$ & 0,235 & 505 \\
\hline 22 & $-3,44$ & 8,29 & 1,79 & 2,80 & $-0,863$ & 0,338 & 493 \\
\hline 23 & $-2,98$ & 8,60 & 1,73 & 2,65 & $-0,735$ & 0,503 & 481 \\
\hline 24 & $-2,92$ & 8,57 & 1,72 & 2,49 & $-0,621$ & 0,618 & 469 \\
\hline 25 & $-2,59$ & 8,98 & 1,77 & 2,29 & $-0,460$ & 0,634 & 457 \\
\hline 26 & $-1,80$ & 8,15 & 1,85 & 2,07 & $-0,510$ & 0,539 & 445 \\
\hline 27 & $-1,75$ & 7,14 & 1,91 & 1,86 & $-0,800$ & 0,347 & 433 \\
\hline 28 & $-1,07$ & 5,86 & 1,94 & 1,68 & $-1,061$ & 0,229 & 421 \\
\hline 29 & $-1,06$ & 5,94 & 1,95 & 1,59 & $-0,973$ & 0,294 & 409 \\
\hline 30 & $-1,01$ & 5,92 & 1,96 & 1,52 & $-0,807$ & 0,346 & 397 \\
\hline
\end{tabular}

Źródło: opracowanie własne na podstawie: Global Financial Data. 
Ta b e l a 4. Dynamika ryzyka względnego indeksu FTSE

\begin{tabular}{|l|c|c|c|c|c|c|c|}
\hline \multicolumn{1}{|c|}{ Horyzont inwestycyjny (lata) } & $\mathbf{1}$ & $\mathbf{5}$ & $\mathbf{1 0}$ & $\mathbf{1 5}$ & $\mathbf{2 0}$ & $\mathbf{2 5}$ & $\mathbf{3 0}$ \\
\hline Ryzyko względne indeksu FTSE & 5,34 & 3,69 & 2,64 & 2,07 & 1,69 & 1,29 & 0,78 \\
\hline Zmiana (\%) & & 30,91 & 50,58 & 61,36 & 68,31 & 75,82 & 85,49 \\
\hline
\end{tabular}

Źródło: opracowanie własne na podstawie: Global Financial Data.

Dynamikę ryzyka względnego realnych stóp zwrotu indeksu FTSE prezentuje tabela 4.

Duża dynamika redukcji ryzyka względnego realnych stóp zwrotu benchmarku rynku brytyjskiego charakteryzuje horyzonty inwestycyjne 1-10 lat. Dla horyzontów o długości 10-25 lat dynamika redukcji ryzyka względnego indeksu FTSE maleje. Impuls wzrostowy analizowanego parametru pojawia się w horyzontach 25-30 lat.

\section{Rynek niemiecki}

Zniszczenia wojenne oraz reparacje wojenne znacznie osłabiły potencjał przemysłowy Niemiec. Pomoc USA i Anglii w odbudowie, eksport surowców dla przemysłu zbrojeniowego do USA w czasie boomu koreańskiego, brak obciążeń wydatkami zbrojeniowymi były silnymi impulsami „niemieckiego cudu gospodarczego". W 1959 r. Niemcy stały się liderem pod względem PKB. W latach sześćdziesiątych znaczącym wsparciem dla Niemiec były kredyty USA, a siłę napędową stanowiły nakłady na rozwój postępu naukowo-technicznego. W latach 1950-1973 produkcja przemysłowa RFN wzrosła prawie 5-krotnie, a utrzymująca się do 1970 r. podwartościowość marki dynamizowała handel zagraniczny (eksport wzrósł ponad trzydziestokrotnie), dając 5\% średnioroczne tempo wzrostu PKB przy jednoczesnym wzroście inflacji. Pierwszy kryzys energetyczny spowodował wzrost inflacji (7\% w 1974 r.) i załamanie koniunktury. Oparta w dużej mierze na węglu gospodarka niemiecka z kryzysu wyszła stosunkowo szybko, osiagając w 1976 r. 14,3 mld USD nadwyżkę w bilansie płatniczym. Drugi kryzys energetyczny nie pozwolił kontynuować łagodnego spadku inflacji, która w 1981 r. osiągnęła 6,3\%. Początek lat osiemdziesiątych to czas słabnięcia marki i redukcji kapitałów zagranicznych. Ograniczenie wydatków budżetowych, wysoki poziom eksportu i inwestycji w okresie 1974-1990 spowodowały 2,3\% wzrost PKB. Przemiany w Europie Środkowo-Wschodniej po 1990 r. dały nowy impuls rozwoju gospodarczego przy kontrolowanym poziomie 
inflacji. Pomimo znacznych wydatków budżetowych z tytułu zjednoczenia Niemiec, gospodarka niemiecka rozwijała się stabilnie. Kryzys subprime osłabił gospodarkę niemiecką. Rynkową interpretację przemian gospodarczych w Niemczech prezentuje rysunek 5.

Ry s u n e k. Wartości indeksu DAX i inflacji Niemiec (1950-2012)

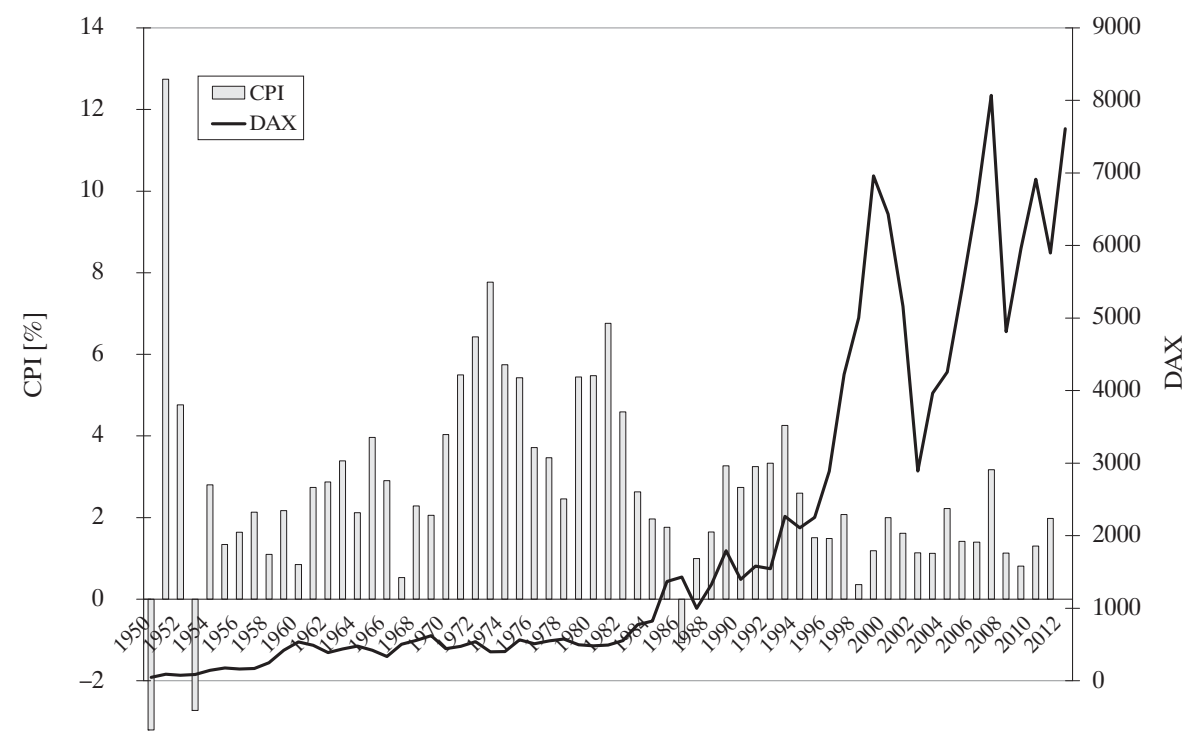

Źródło: opracowanie własne na podstawie: Global Financial Data.

Dobra koniunktura niemieckiej giełdy w latach 1950-1958 reprezentowana relatywnie małymi fluktuacjami benchmarku wokół trendu wzrostowego koresponduje z dobrą kondycją niemieckiej gospodarki w tym okresie. Pomimo kryzysów energetycznych kondycja niemieckiej gospodarki była dobra, na co wskazuje utrzymujący się przez dwie dekady (1959-1982) wzrostowy trend giełdowy. Silnie wzrostowa koniunktura giełdy niemieckiej w okresie 1983-1995 reprezentuje kondycję gospodarki przełomu lat osiemdziesiątych i dziewięćdziesiątych. Znaczne fluktuacje indeksu DAX wokół trendu są adekwatne do obciążeń ekonomicznych związanych ze zjednoczeniem Niemiec. Trend wzrostowy w okresie 1996-2012 świadczy o dobrej kondycji gospodarki niemieckiej w pierwszej dekadzie XXI wieku. Wpływ otoczenia zewnętrznego na gospodarkę niemiecką manifestuje się podobnie jak u pozostałych dużymi fluktuacjami benchmarku. Charakterystyki rozkładów realnych stóp zwrotu indeksu DAX prezentuje tabela 5. 
Ta b e l a 5. Charakterystyki rozkładów realnych stóp zwrotu indeksu DAX

\begin{tabular}{|c|c|c|c|c|c|c|c|}
\hline \multirow{2}{*}{$\begin{array}{l}\text { Horyzont } \\
\text { inwesty- } \\
\text { cyjny } \\
\text { (lata) }\end{array}$} & \multicolumn{3}{|c|}{ Stopa zwrotu } & \multirow{2}{*}{$\begin{array}{c}\text { Odchylenie } \\
\text { standar- } \\
\text { dowe } \\
(\%)\end{array}$} & \multirow[b]{2}{*}{ Kurtoza } & \multirow[b]{2}{*}{ Skośność } & \multirow[b]{2}{*}{$\begin{array}{c}\text { Ilośćc } \\
\text { obserwacj }\end{array}$} \\
\hline & $\underset{(\%)}{\operatorname{minimum}}$ & $\begin{array}{c}\text { maksi- } \\
\text { mum } \\
(\%)\end{array}$ & $\begin{array}{c}\text { wartość } \\
\text { oczekiwana } \\
(\%)\end{array}$ & & & & \\
\hline 1 & $-52,60$ & 98,18 & 7,09 & 25,03 & 0,193 & 0,538 & 745 \\
\hline 2 & $-36,60$ & 70,75 & 5,67 & 18,50 & 0,511 & 0,652 & 733 \\
\hline 3 & $-32,71$ & 54,24 & 4,88 & 14,30 & 0,380 & 0,672 & 721 \\
\hline 4 & $-18,34$ & 39,51 & 4,52 & 11,87 & $-0,305$ & 0,622 & 709 \\
\hline 5 & $-16,05$ & 28,93 & 4,34 & 10,38 & $-0,766$ & 0,473 & 697 \\
\hline 6 & $-12,87$ & 30,95 & 4,17 & 9,04 & $-0,296$ & 0,619 & 685 \\
\hline 7 & $-10,09$ & 33,14 & 4,04 & 8,21 & 0,594 & 0,931 & 673 \\
\hline 8 & $-8,61$ & 27,93 & 3,93 & 7,53 & 0,672 & 0,993 & 661 \\
\hline 9 & $-10,66$ & 25,37 & 3,80 & 7,10 & 0,580 & 0,869 & 649 \\
\hline 10 & $-6,76$ & 26,18 & 3,56 & 6,64 & 1,011 & 0,886 & 637 \\
\hline 11 & $-6,17$ & 23,70 & 3,33 & 6,06 & 0,601 & 0,699 & 625 \\
\hline 12 & $-6,02$ & 19,59 & 3,18 & 5,42 & $-0,287$ & 0,348 & 613 \\
\hline 13 & $-6,74$ & 15,90 & 3,15 & 4,90 & $-0,381$ & 0,109 & 601 \\
\hline 14 & $-7,35$ & 15,87 & 3,12 & 4,54 & $-0,276$ & 0,057 & 589 \\
\hline 15 & $-5,90$ & 13,78 & 3,08 & 4,26 & $-0,566$ & 0,055 & 577 \\
\hline 16 & $-5,46$ & 11,94 & 3,04 & 4,02 & $-0,596$ & 0,036 & 565 \\
\hline 17 & $-5,06$ & 10,77 & 3,01 & 3,85 & $-0,497$ & 0,062 & 553 \\
\hline 18 & $-4,72$ & 11,36 & 2,97 & 3,73 & $-0,273$ & 0,138 & 541 \\
\hline 19 & $-4,80$ & 11,14 & 2,91 & 3,53 & $-0,201$ & 0,058 & 529 \\
\hline 20 & $-4,88$ & 10,54 & 2,84 & 3,22 & $-0,032$ & $-0,121$ & 517 \\
\hline 21 & $-5,07$ & 9,38 & 2,79 & 2,90 & 0,269 & $-0,298$ & 505 \\
\hline 22 & $-5,02$ & 8,86 & 2,77 & 2,72 & 0,014 & $-0,274$ & 493 \\
\hline 23 & $-3,57$ & 8,42 & 2,77 & 2,55 & $-0,508$ & $-0,205$ & 481 \\
\hline 24 & $-3,08$ & 6,94 & 2,77 & 2,31 & $-0,814$ & $-0,064$ & 469 \\
\hline 25 & $-1,57$ & 7,24 & 2,79 & 2,13 & $-0,997$ & 0,261 & 457 \\
\hline 26 & $-1,37$ & 6,91 & 2,81 & 1,95 & $-0,888$ & 0,286 & 445 \\
\hline 27 & $-1,81$ & 6,27 & 2,86 & 1,78 & $-0,631$ & $-0,174$ & 433 \\
\hline 28 & $-1,49$ & 5,88 & 2,88 & 1,63 & $-0,487$ & $-0,390$ & 421 \\
\hline 29 & $-0,47$ & 5,52 & 2,88 & 1,47 & $-0,717$ & $-0,441$ & 409 \\
\hline 30 & $-1,00$ & 5,27 & 2,87 & 1,41 & $-0,601$ & $-0,606$ & 397 \\
\hline
\end{tabular}

Źródło: opracowanie własne na podstawie Global Financial Data. 
Wartości oczekiwanych stóp zwrotu dla 30-letniego horyzontu są ponad 2-krotnie mniejsze od wartości oczekiwanych stóp zwrotu dla horyzontu jednorocznego. Relacje wartości odchylenia standardowego dla analogicznych horyzontów są prawie siedemnastokrotne. Wartości ryzyka względnego realnych oczekiwanych stóp zwrotu indeksu DAX w zależności od długości horyzontu inwestycyjnego ilustruje rysunek 6 .

\section{R y s u n e 6. Wartości ryzyka względnego indeksu DAX}

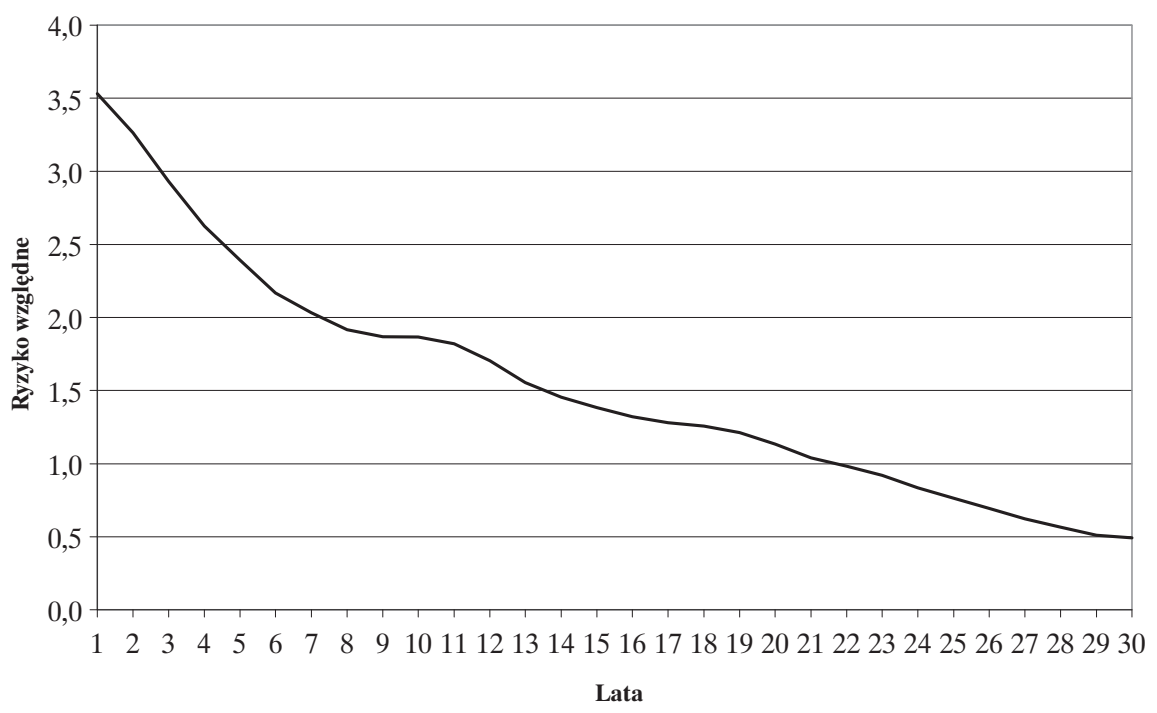

Źródło: opracowanie własne na podstawie: Global Financial Data.

Ta b e l a 6. Dynamika ryzyka względnego indeksu DAX

\begin{tabular}{|l|c|c|c|c|c|c|c|}
\hline \multicolumn{1}{|c|}{ Horyzont inwestycyjny [lata] } & $\mathbf{1}$ & $\mathbf{5}$ & $\mathbf{1 0}$ & $\mathbf{1 5}$ & $\mathbf{2 0}$ & $\mathbf{2 5}$ & $\mathbf{3 0}$ \\
\hline Ryzyko względne indeksu DAX & 3,53 & 2,39 & 1,87 & 1,38 & 1,13 & 0,76 & 0,49 \\
\hline Zmiana (\%) & & 32,34 & 47,16 & 60,84 & 67,85 & 78,33 & 86,14 \\
\hline
\end{tabular}

Źródło: opracowanie własne na podstawie: Global Financial Data.

Dynamikę ryzyka względnego realnych stóp zwrotu indeksu DAX prezentuje tabela 6.

Większa dynamika redukcji ryzyka względnego realnych stóp zwrotu benchmarku rynku niemieckiego charakteryzuje horyzonty inwestycyjne 1-15 lat. Dla horyzontów o długości 15-20 lat dynamika redukcji ryzyka względnego indeksu DAX jest bardziej stabilna. Impuls wzrostowy analizo- 
wanego parametru pojawia się w horyzontach 20-25 lat. Dynamika redukcji ryzyka względnego realnej stopy zwrotu indeksów DAX oraz FTSE na przestrzeni 30-letniego horyzontu inwestycyjnego jest porównywalna.

\section{Rynek francuski}

W odbudowie francuskiej gospodarki istotną rolę odegral plan Marshalla oraz pomoc USA. Fundamentem polityki gospodarczej Francji było centralne planowanie oraz nacjonalizacja sektorów: energetycznego, górnictwa węglowego, transportu lotniczego, znacznej części banków. Militarne zaangażowanie w Indochinach nie pozwoliło na pełne wykorzystanie przez Francję proeksportowej koniunktury boomu koreańskiego - w latach 1952-1953 zanotowano spadek tempa rozwoju. Zaangażowanie militarne w Indochinach oraz w Algierii poskutkowało brakiem odporności Francji na ogólnoświatowy spadek koniunktury w latach 1958-1959. Realizacja programu Wielkiej Francji opartego na mocnej gospodarce oraz dewaluacja i wymiana franka zwiększyły konkurencyjność eksportu. Zasilenie kapitałowe i technologiczne z USA spowodowały latach 1960-1970 średni wzrost PKB o 5,7\%. Recesja gospodarcza spowodowana pierwszym kryzysem energetycznym miała mniejsze rozmiary niż w innych krajach - w 1980 r. Francja pod względem wielkości dochodu narodowego ustępowała tylko RFN. Koniec drugiego kryzysu energetycznego zbiegł się ze zmianami politycznymi, rządy prawicowo-liberalne zastąpione zostały w 1981 r. - lewicowymi. Konsekwencją osłabienia kryzysami naftowymi oraz przeprowadzonej za wysokimi odszkodowaniami nacjonalizacji było pogorszenie konkurencyjności gospodarki francuskiej, co z kolei wywołało kilkunastoprocentową inflację. W 1981-1983 ze względu na trudności handlowe nastąpiły dwie dewaluacje franka. W 1986 r., po objęciu rządów przez prawicę, dokonano reprywatyzacji wobec znacjonalizowanych banków i przedsiębiorstw. W 1974-1990 Francja rozwijała się dość dobrze, szybciej niż Anglia i podobnie jak Niemcy. Przemiany w Europie Środkowo-Wschodniej nie były dla gospodarki francuskiej, jak dla gospodarki niemieckiej, silnym impulsem. W pierwszej dekadzie XXI w. gospodarka francuska rozwijała się w miarę stabilnie. Kryzys subprime wywołał w porównaniu z Anglią i USA relatywnie mniejsze osłabienie. Rynkową interpretację zjawisk zachodzących w gospodarce francuskiej prezentuje rysunek 7.

Niezbyt duże amplitudy fluktuacji benchmarku francuskiego rynku akcji wokół umiarkowanie wzrostowego trendu w okresie 1950-1962 sugerują, że 
Ry s u n k 7. Wartości indeksu CAC 40 i inflacji Francji (1950-2012)

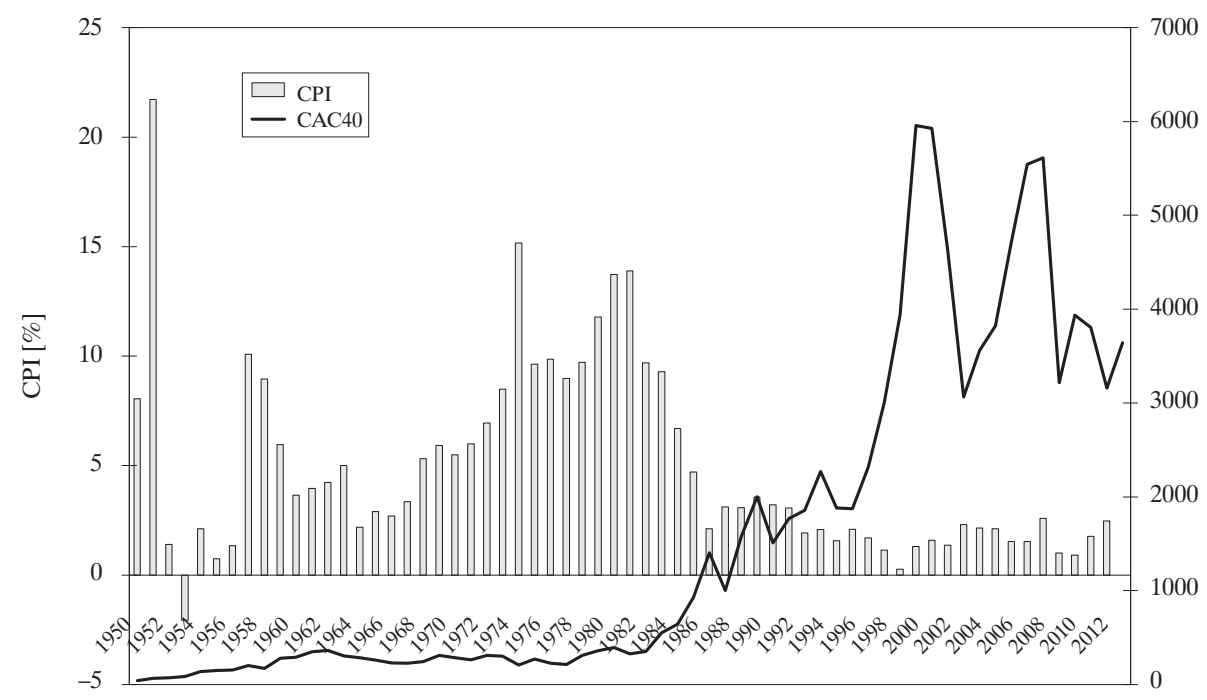

Źródło: opracowanie własne na podstawie: Global Financial Data.

przegranie wojny w Indochinach (1945-1954) oraz w Algierii (1954-1962) nie wpłynęło na zachowanie tego rynku. Relatywnie większe odchylenie indeksu od linii trendu w 1958 r. sygnalizuje małą odporność francuskiej gospodarki na ogólnoświatowy spadek koniunktury w latach 1958-1959. Dewaluacja franka (1960 r.) pobudzająca eksport i postęp technologiczny zdynamizowały gospodarkę francuską lat siedemdziesiątych. Zarówno dobra kondycja gospodarki francuskiej, jak i lepsza od innych krajów kompensacja negatywnych skutków obu kryzysów energetycznych pozwoliły na utrzymanie korzystnej koniunktury giełdowej, ale o słabszym niż poprzednio trendzie wzrostowym i silniejszych fluktuacjach benchmarku. Dwie dewaluacje franka w latach 1981-1983 zainicjowały piętnastoletni okres silnego trendu wzrostowego indeksu CAC40, którego znaczna dynamika była reakcją rynku na burzliwe przemiany polityczno-gospodarcze w europie końca XX wieku. Rosnąca skala wzajemnych oddziaływań rynkowych w wyniku postępującego procesu globalizacji przejawiała się znaczną niestabilnością benchmarku giełdy paryskiej wokół trendu spadkowego w okresie 1997-2012. Charakterystyki rozkładów realnych stóp zwrotu indeksu CAC 40 prezentuje tabela 7.

Wartości oczekiwanych stóp zwrotu dla 30-letniego horyzontu są ponad 2-krotnie mniejsze od wartości oczekiwanych stóp zwrotu dla horyzontu 
Tabela 7. Charakterystyki rozkładów realnych stóp zwrotu indeksu CAC 40

\begin{tabular}{|c|c|c|c|c|c|c|c|}
\hline \multirow{2}{*}{$\begin{array}{c}\text { Horyzont } \\
\text { inwesty- } \\
\text { cyjny } \\
\text { (lata) }\end{array}$} & \multicolumn{3}{|c|}{ Stopa zwrotu } & \multirow{2}{*}{$\begin{array}{c}\text { Odchylenie } \\
\text { standar- } \\
\text { dowe } \\
(\%)\end{array}$} & \multirow[b]{2}{*}{ Kurtoza } & \multirow[b]{2}{*}{ Skośność } & \multirow[b]{2}{*}{$\begin{array}{c}\text { Ilośćć } \\
\text { obserwacji }\end{array}$} \\
\hline & $\begin{array}{c}\underset{(\%)}{\operatorname{minimum}} \\
\end{array}$ & $\begin{array}{c}\text { maksi- } \\
\text { mum } \\
(\%)\end{array}$ & $\begin{array}{c}\text { wartość } \\
\text { oczekiwana } \\
(\%)\end{array}$ & & & & \\
\hline 1 & $-50,02$ & 81,60 & 4,80 & 22,67 & 0,106 & 0,286 & 745 \\
\hline 2 & $-34,50$ & 50,00 & 3,79 & 16,82 & $-0,415$ & 0,264 & 733 \\
\hline 3 & $-26,77$ & 39,63 & 3,37 & 14,03 & $-0,573$ & 0,361 & 721 \\
\hline 4 & $-24,15$ & 34,08 & 3,11 & 12,41 & $-0,386$ & 0,482 & 709 \\
\hline 5 & $-18,74$ & 27,45 & 2,90 & 10,75 & $-0,616$ & 0,393 & 697 \\
\hline 6 & $-15,22$ & 24,03 & 2,75 & 9,29 & $-0,870$ & 0,322 & 685 \\
\hline 7 & $-13,82$ & 22,14 & 2,65 & 8,45 & $-0,943$ & 0,265 & 673 \\
\hline 8 & $-13,40$ & 18,97 & 2,52 & 7,96 & $-1,070$ & 0,144 & 661 \\
\hline 9 & $-10,90$ & 17,53 & 2,45 & 7,69 & $-1,226$ & 0,086 & 649 \\
\hline 10 & $-9,69$ & 16,03 & 2,32 & 7,30 & $-1,380$ & 0,038 & 637 \\
\hline 11 & $-9,78$ & 15,23 & 2,22 & 6,90 & $-1,401$ & $-0,049$ & 625 \\
\hline 12 & $-9,97$ & 14,27 & 2,18 & 6,52 & $-1,294$ & $-0,124$ & 613 \\
\hline 13 & $-9,11$ & 13,51 & 2,16 & 6,02 & $-1,227$ & $-0,241$ & 601 \\
\hline 14 & $-9,72$ & 12,50 & 2,14 & 5,70 & $-1,064$ & $-0,286$ & 589 \\
\hline 15 & $-10,35$ & 13,28 & 2,13 & 5,55 & $-0,789$ & $-0,194$ & 577 \\
\hline 16 & $-9,26$ & 13,86 & 2,10 & 5,40 & $-0,602$ & $-0,081$ & 565 \\
\hline 17 & $-8,25$ & 14,55 & 2,05 & 5,26 & $-0,470$ & $-0,014$ & 553 \\
\hline 18 & $-7,44$ & 14,25 & 2,01 & 5,10 & $-0,479$ & 0,005 & 541 \\
\hline 19 & $-7,76$ & 13,65 & 1,99 & 4,95 & $-0,637$ & $-0,039$ & 529 \\
\hline 20 & $-7,67$ & 11,63 & 1,96 & 4,75 & $-0,783$ & $-0,121$ & 517 \\
\hline 21 & $-7,03$ & 10,71 & 1,93 & 4,56 & $-0,838$ & $-0,080$ & 505 \\
\hline 22 & $-6,17$ & 11,32 & 1,92 & 4,44 & $-0,892$ & 0,033 & 493 \\
\hline 23 & $-5,70$ & 11,01 & 1,91 & 4,23 & $-0,874$ & 0,184 & 481 \\
\hline 24 & $-5,45$ & 9,86 & 1,90 & 3,97 & $-0,894$ & 0,249 & 469 \\
\hline 25 & $-5,26$ & 9,10 & 1,91 & 3,71 & $-0,979$ & 0,234 & 457 \\
\hline 26 & $-4,34$ & 9,01 & 1,95 & 3,44 & $-1,094$ & 0,156 & 445 \\
\hline 27 & $-3,74$ & 7,39 & 2,00 & 3,18 & $-1,262$ & 0,069 & 433 \\
\hline 28 & $-3,38$ & 7,55 & 2,03 & 2,93 & $-1,257$ & 0,106 & 421 \\
\hline 29 & $-2,31$ & 7,70 & 2,03 & 2,69 & $-1,234$ & 0,278 & 409 \\
\hline 30 & $-1,73$ & 7,62 & 2,00 & 2,46 & $-1,166$ & 0,370 & 397 \\
\hline
\end{tabular}

Źródło: opracowanie własne na podstawie: Global Financial Data. 
jednorocznego. Relacje wartości odchylenia standardowego dla analogicznych horyzontów są ponad dziewięciokrotne. Wartości ryzyka względnego realnych oczekiwanych stóp zwrotu indeksu CAC 40 w zależności od długości horyzontu inwestycyjnego ilustruje rysunek 8.

Dynamikę ryzyka względnego realnych stóp zwrotu indeksu CAC 40 prezentuje tabela 8 .

Ry s u n e $k$. Wartości ryzyka względnego indeksu CAC 40

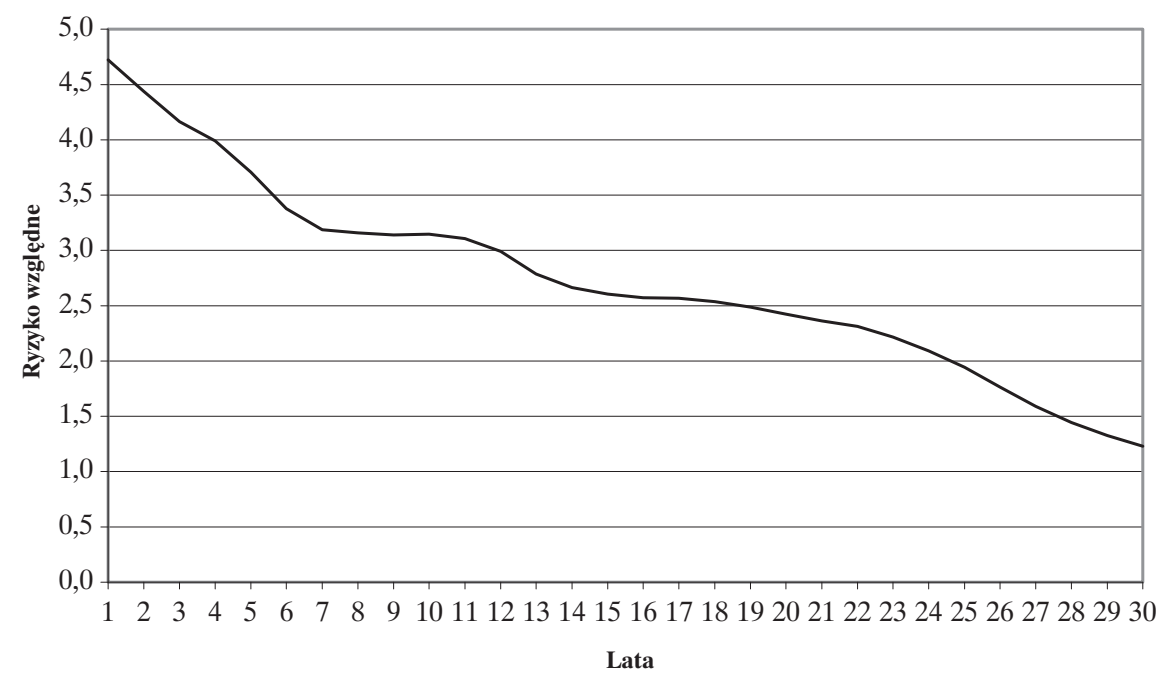

Źródło: opracowanie własne na podstawie: Global Financial Data.

Ta b e la 8. Dynamika ryzyka względnego indeksu CAC 40

\begin{tabular}{|l|c|c|c|c|c|c|c|}
\hline \multicolumn{1}{|c|}{ Horyzont inwestycyjny (lata) } & $\mathbf{1}$ & $\mathbf{5}$ & $\mathbf{1 0}$ & $\mathbf{1 5}$ & $\mathbf{2 0}$ & $\mathbf{2 5}$ & \multicolumn{1}{c|}{$\mathbf{3 0}$} \\
\hline Ryzyko względne indeksu CAC 40 & 4,73 & 3,70 & 3,14 & 2,61 & 2,42 & 1,94 & 1,23 \\
\hline Zmiana (\%) & & 21,65 & 33,51 & 44,76 & 48,72 & 58,86 & 73,95 \\
\hline
\end{tabular}

Źródło: opracowanie własne na podstawie: Global Financial Data.

Benchmark rynku francuskiego charakteryzuje znacznie mniejsza dynamika redukcji ryzyka względnego realnych stóp zwrotu w porównaniu z wcześniej analizowanymi indeksami. Dynamika analizowanego parametru jest stabilna dla horyzontów inwestycyjnych 5-15 lat. Dla horyzontów o długości 15-25 lat dynamika redukcji ryzyka względnego indeksu CAC 40 stabilizuje się na niższym poziomie. Impuls wzrostowy analizowanego parametru 
pojawia się w horyzontach 25-30 lat. Dynamika redukcji ryzyka względnego realnej stopy zwrotu indeksów CAC 40 oraz DJIA wykazuje podobieństwo.

\section{Rynek japoński}

Skutkiem utraty kolonii oraz znacznych zniszczeń podczas II wojny światowej była depresja gospodarcza w okresie powojennym. Zwycięstwo komunistów w Chinach w 1949 r. zmusiło USA do zmiany polityki wobec Japonii. Wdrożenie drastycznych reform oraz 2 mld USD kredytu od USA nie przywróciły przedwojennego poziomu produkcji przemysłowej. Silnym impulsem była wojna koreańska - z tytułu obsługi wojskowej i aprowizacyjnej Japonia otrzymała od USA 1,4 mld USD, zdynamizował się eksport. Kolejny silny impuls wzrostowy pojawił się na skutek wojny wietnamskiej (1964-1973). W wyniku stabilizacji politycznej i interwencjonizmu państwowego w latach 1950-1973 gospodarka japońska, nazywana „cudem gospodarczym”, rozwijała się średniorocznie w tempie: PKB 9,2\%; produkcja przemysłowa 14,6\%; inflacja 5,2\%. Efektem znacznego uzależnienia gospodarki od importu był spadek tempa wzrostu PKB oraz wzrost inflacji (24\%) na skutek pierwszego kryzysu energetycznego. W wyniku reakcji, jaką było znaczne ograniczenie wydatków budżetowych, inflacja obniżyła się w 1976 r. do poziomu $10 \%$, a w 1978 r. wyniosła 4,2\%, co przyczyniło się do aprecjacji jena. Mimo że drugi kryzys energetyczny był mniej dotkliwy dla gospodarki japońskiej, jen uległ deprecjacji. W latach osiemdziesiątych nastąpiło ograniczenie importu oraz ożywienie eksportu - szczególnie eksportu kapitału, dzięki czemu Japonia była liderem inwestycji zagranicznych, co przyczyniło się do aprecjacji i internacjonalizacji jena. Dynamicznie rosnący popyt wewnętrzny i niska inflacja $\mathrm{w}$ drugiej połowie lat osiemdziesiątych wykreowały koniunkturę sprzyjającą inwestycjom z dźwignią finansową, nazywaną „bańką mydlaną". Gospodarka japońska w latach 1974-1990 rozwijała się najszybciej spośród rozwiniętych krajów kapitalistycznych, osiągając średnioroczne tempo: PKB, 3,9\%; produkcji przemysłowej 3,5\%; inflacji 5,2\%. W obawie przed skutkami „pęknięcia bańki mydlanej” bank Japonii od 1989 r. zaczął podnosić stopy procentowe, co wywołało pęknięcie bańki i aprecjację jena. Nastąpiło pierwsze w historii powojennej spowolnienie, a tempo wzrostu PKB Japonii było niższe od tempa wzrostu pozostałych wysoko rozwiniętych państw, powodując w latach 1991-1993 recesję Heisei. Wzrost inwestycji i konsumpcji w latach 1995-1996 wywołały ożywienie, ale natychmiastowe 
podniesienie stawek podatkowych spowodowało powrót recesji. Zła polityka kredytowa lat osiemdziesiątych, negatywne zjawiska w gospodarcze oraz kryzys azjatycki 1997-1999 wywołały kryzys w sektorze bankowym. Reakcja było podniesienie wymogów zdolności kredytowej, co skutkowało w latach 2000-2002 kolejną recesją gospodarki realnej. Lata dziewięćdziesiąte XX w., nazywane „straconą dekadą” Japonii, będą konsekwencją długotrwałej deflacji. Zapoczątkowany w ostatniej dekadzie XX w. kryzys utrzymał się w pierwszej dekadzie XXI w. Rynkową interpretację etapów rozwoju gospodarki japońskiej prezentuje rysunek 9.

\section{R y s u n e 9. Wartości indeksu NIKKEI 225 i inflacji Japonii (1950-2012)}

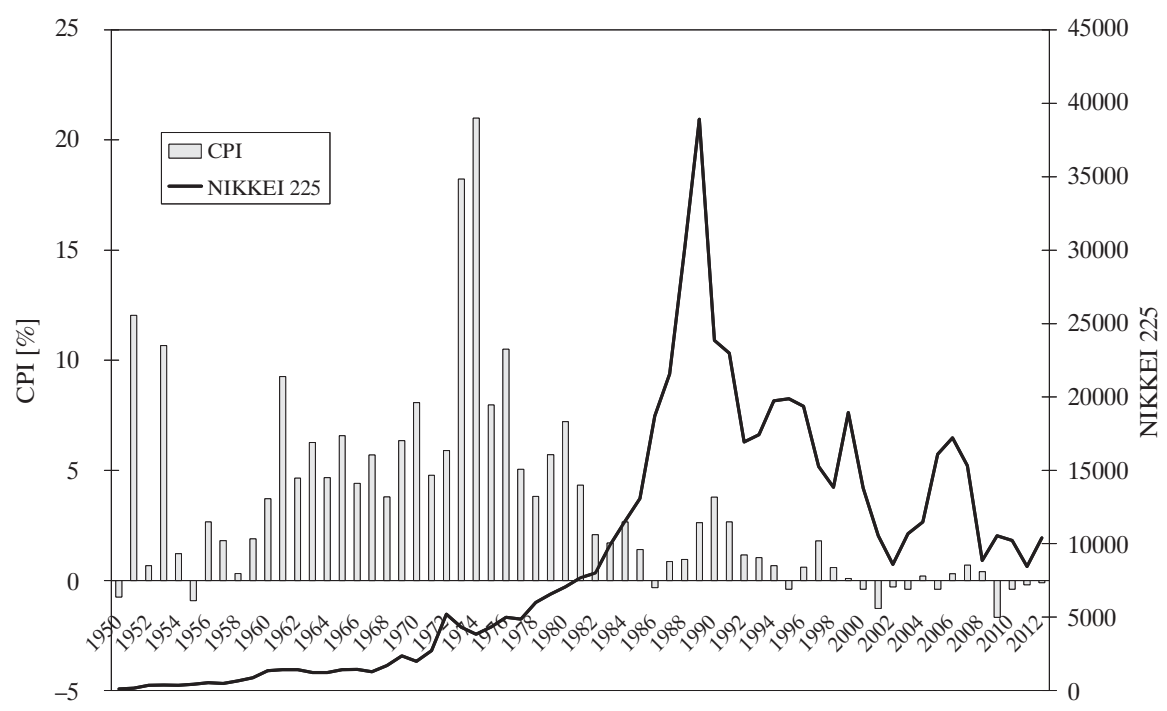

Źródło: opracowanie własne na podstawie: Global Financial Data.

Japoński „cud gospodarczy” na tokijskiej giełdzie manifestował się silnym trendem wzrostowym w okresie 1950-1958, następnie nieznacznie osłabł w okresie 1959-1968 i zdynamizował się w końcowej fazie 1970-1972. Wywołane kryzysami energetycznymi negatywne skutki gospodarcze nie zmieniły wzrostowej koniunktury giełdy tokijskiej w okresie 1969-1982. Symptomem giełdowym eksplozji japońskiego eksportu w latach osiemdziesiątych oraz „polityki budzenia konsumpcji krajowej” był wykładniczy trend wzrostowy benchmarku giełdy tokijskiej w latach 1983-1989. Następstwem ,gospodarki bańki mydlanej” był kryzys początku lat dziewięćdziesiątych rozpoczynający 
spadkową koniunkturę giełdową kontynuowaną w wyniku kryzysów azjatyckiego i subprime. Charakterystyki rozkładów realnych stóp zwrotu indeksu NIKKEI 225 prezentuje tabela 9.

Ta b e l a 9. Charakterystyki rozkładów realnych stóp zwrotu indeksu NIKKEI 225

\begin{tabular}{|c|c|c|c|c|c|c|c|}
\hline \multirow{2}{*}{$\begin{array}{c}\text { Horyzont } \\
\text { inwesty- } \\
\text { cyjny } \\
\text { (lata) }\end{array}$} & \multicolumn{3}{|c|}{ Stopa zwrotu } & \multirow{2}{*}{$\begin{array}{c}\text { Odchylenie } \\
\text { standar- } \\
\text { dowe } \\
(\%)\end{array}$} & \multirow[b]{2}{*}{ Kurtoza } & \multirow[b]{2}{*}{ Skośność } & \multirow[b]{2}{*}{$\begin{array}{c}\text { Ilość } \\
\text { obserwacji }\end{array}$} \\
\hline & $\underset{(\%)}{\operatorname{minimum}}$ & $\begin{array}{c}\underset{(\%)}{\operatorname{maximum}} \\
\end{array}$ & $\begin{array}{c}\text { wartość } \\
\text { oczekiwana } \\
(\%)\end{array}$ & & & & \\
\hline 1 & $-49,60$ & 136,81 & 6,84 & 25,05 & 2,070 & 0,894 & 745 \\
\hline 2 & $-34,72$ & 88,85 & 5,61 & 18,65 & 0,840 & 0,658 & 733 \\
\hline 3 & $-26,31$ & 63,67 & 4,82 & 14,91 & 0,060 & 0,473 & 721 \\
\hline 4 & $-20,24$ & 35,00 & 4,22 & 12,62 & $-0,906$ & 0,324 & 709 \\
\hline 5 & $-15,82$ & 28,78 & 4,05 & 11,35 & $-0,856$ & 0,411 & 697 \\
\hline 6 & $-14,14$ & 28,05 & 4,00 & 10,01 & $-0,600$ & 0,509 & 685 \\
\hline 7 & $-13,82$ & 25,22 & 3,92 & 8,99 & $-0,633$ & 0,491 & 673 \\
\hline 8 & $-12,28$ & 23,99 & 3,80 & 8,36 & $-0,663$ & 0,467 & 661 \\
\hline 9 & $-12,01$ & 24,96 & 3,70 & 7,96 & $-0,169$ & 0,535 & 649 \\
\hline 10 & $-9,49$ & 26,82 & 3,52 & 7,47 & 0,316 & 0,632 & 637 \\
\hline 11 & $-9,95$ & 26,47 & 3,34 & 7,02 & 0,401 & 0,547 & 625 \\
\hline 12 & $-11,07$ & 22,11 & 3,17 & 6,48 & 0,068 & 0,218 & 613 \\
\hline 13 & $-11,66$ & 19,50 & 3,10 & 6,02 & $-0,091$ & $-0,068$ & 601 \\
\hline 14 & $-10,59$ & 16,69 & 3,07 & 5,66 & $-0,400$ & $-0,282$ & 589 \\
\hline 15 & $-8,83$ & 14,47 & 3,06 & 5,39 & $-0,565$ & $-0,357$ & 577 \\
\hline 16 & $-7,36$ & 14,37 & 3,09 & 5,10 & $-0,723$ & $-0,368$ & 565 \\
\hline 17 & $-6,44$ & 13,15 & 3,13 & 4,83 & $-0,883$ & $-0,328$ & 553 \\
\hline 18 & $-7,00$ & 12,45 & 3,17 & 4,74 & $-0,789$ & $-0,228$ & 541 \\
\hline 19 & $-8,24$ & 12,95 & 3,23 & 4,63 & $-0,562$ & $-0,250$ & 529 \\
\hline 20 & $-7,55$ & 12,69 & 3,27 & 4,49 & $-0,403$ & $-0,320$ & 517 \\
\hline 21 & $-6,69$ & 12,91 & 3,30 & 4,41 & $-0,097$ & $-0,268$ & 505 \\
\hline 22 & $-7,06$ & 14,22 & 3,37 & 4,27 & 0,269 & $-0,190$ & 493 \\
\hline 23 & $-6,24$ & 14,05 & 3,41 & 3,92 & 0,418 & $-0,237$ & 481 \\
\hline 24 & $-5,25$ & 11,81 & 3,46 & 3,46 & 0,163 & $-0,333$ & 469 \\
\hline 25 & $-4,70$ & 10,44 & 3,54 & 3,12 & $-0,102$ & $-0,326$ & 457 \\
\hline 26 & $-3,33$ & 10,03 & 3,62 & 2,83 & $-0,494$ & $-0,233$ & 445 \\
\hline 27 & $-1,97$ & 9,50 & 3,67 & 2,64 & $-0,798$ & $-0,165$ & 433 \\
\hline 28 & $-1,31$ & 9,23 & 3,70 & 2,62 & $-0,938$ & $-0,124$ & 421 \\
\hline 29 & $-1,15$ & 9,37 & 3,73 & 2,68 & $-0,985$ & $-0,047$ & 409 \\
\hline 30 & $-1,78$ & 9,12 & 3,73 & 2,71 & $-0,991$ & 0,039 & 397 \\
\hline
\end{tabular}

Źródło: opracowanie własne na podstawie: Global Financial Data. 
Wartości oczekiwanych stóp zwrotu dla 30-letniego horyzontu są 1,8-krotnie mniejsze od wartości oczekiwanych stóp zwrotu dla horyzontu jednorocznego. Relacje wartości odchylenia standardowego dla analogicznych horyzontów są ponad dziewięciokrotne. Wartości ryzyka względnego realnych oczekiwanych stóp zwrotu indeksu NIKKEI 225 w zależności od długości horyzontu inwestycyjnego ilustruje rysunek 10.

Ry s u n e 10 . Wartości ryzyka względnego indeksu NIKKEI 225

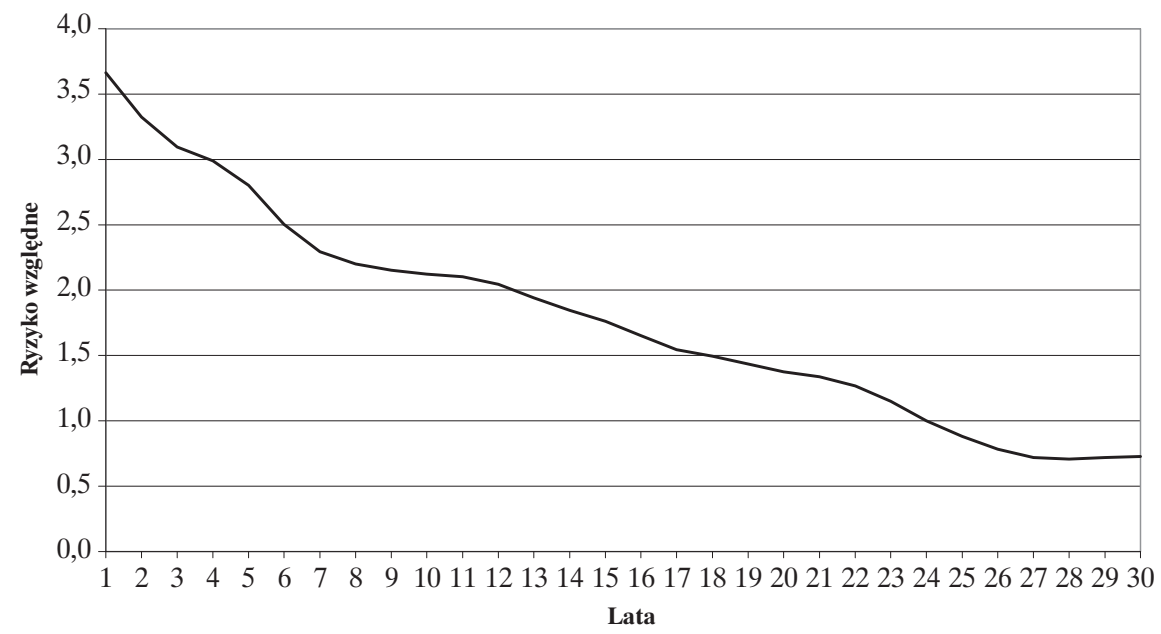

Źródło: opracowanie własne na podstawie: Global Financial Data.

Ta b e l a 1 0. Dynamika zmiany ryzyka względnego indeksu NIKKEI 225

\begin{tabular}{|l|c|r|r|r|r|r|r|}
\hline \multicolumn{1}{|c|}{ Horyzont inwestycyjny (lata) } & \multicolumn{1}{c|}{$\mathbf{1}$} & $\mathbf{5}$ & \multicolumn{1}{|c|}{$\mathbf{1 0}$} & $\mathbf{1 5}$ & $\mathbf{2 0}$ & \multicolumn{1}{|c|}{$\mathbf{2 5}$} & \multicolumn{1}{c|}{$\mathbf{3 0}$} \\
\hline Ryzyko względne indeksu NIKKEI 225 & 3,66 & 2,80 & 2,12 & 1,76 & 1,37 & 0,88 & 0,73 \\
\hline Zmiana (\%) & & 23,35 & 41,97 & 51,81 & 62,49 & 75,88 & 80,16 \\
\hline
\end{tabular}

Źródło: opracowanie własne na podstawie: Global Financial Data.

Dynamikę zmiany ryzyka względnego realnych stóp zwrotu indeksu NIKKEI 225 prezentuje tabela 10.

Benchmark rynku japońskiego charakteryzuje relatywnie mniejsza dynamika redukcji ryzyka względnego realnych stóp zwrotu. Dynamika analizowanego parametru jest stabilna dla horyzontów inwestycyjnych 5-25 lat. Dla horyzontów o długości 25-30 lat dynamika redukcji ryzyka względnego indeksu NIKKEI 225 słabnie. 


\section{Podsumowanie}

Wartości ryzyka względnego realnych stóp zwrotu indeksu FTSE osiągają najwyższy poziom dla horyzontów 1-5 lat (rys. 11). W dłuższych horyzontach najwyższe wartości ryzyka względnego osiągają indeks CAC 40. Poziom ryzyka względnego indeksu DAX jest najniższy dla wszystkich analizowanych horyzontów inwestycyjnych.

Ry s u n e 11 . Ryzyko względne realnych stóp zwrotu indeksów giełdowych

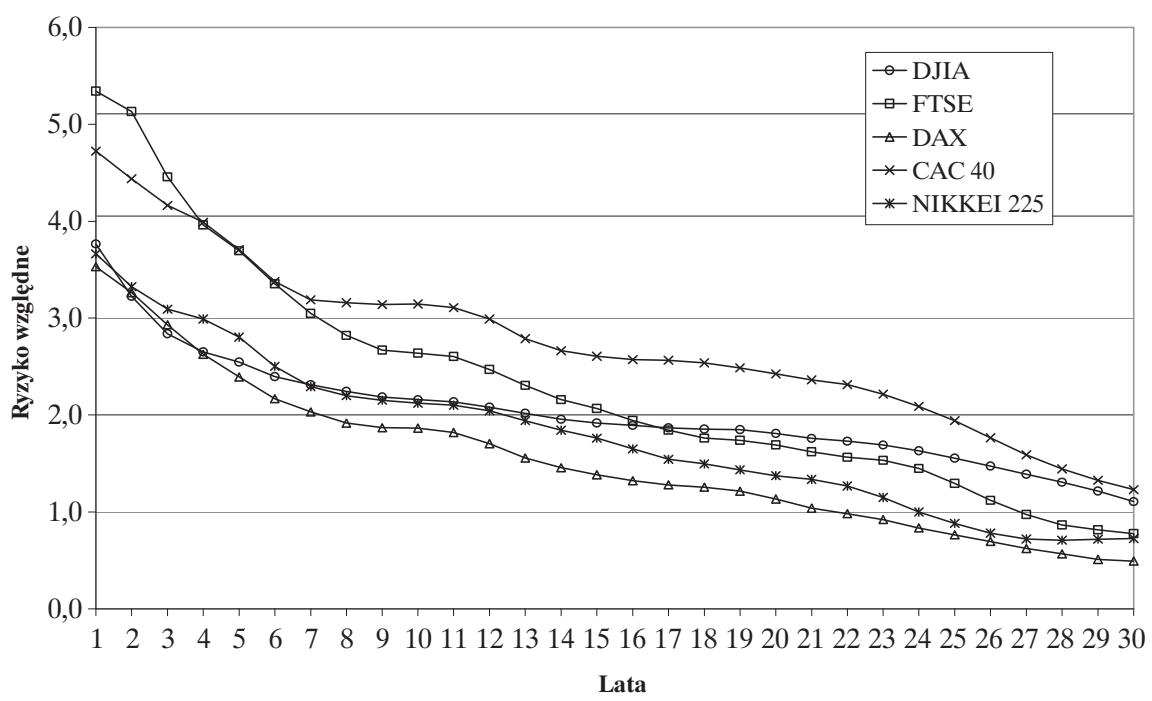

Źródło: opracowanie własne na podstawie: Global Financial Data.

W krótkich horyzontach (1-5 lat) największa dynamika redukcji ryzyka względnego realnych stóp zwrotu charakteryzuje indeksy DJIA, DAX, FTSE (32,5-30,3\%), mniejszą dynamikę wykazały indeksy CAC 40 i NIKKEI 225 $(23,4$ i $21,7 \%)$.

W dziesięcioletnich horyzontach największa dynamika redukcji ryzyka względnego charakteryzowała indeksy FTSE $(50,6 \%)$ oraz DAX $(47,2 \%)$; indeksy DJIA, NIKKEI 225 porównywalnie redukowały ryzyko względne (42,6 i 42\%); najmniej dynamicznie następuje redukcja ryzyka względnego dla indeksu CAC $40(33,5 \%)$.

Indeksami dynamicznie redukującymi ryzyko względne realnych stóp zwrotu w horyzontach piętnastoletnich były: FTSE i DAX (61,4 i 60,8\%), 
pozostałe indeksy charakteryzuje mniejsza dynamika redukcji ryzyka względnego: NIKKEI 225 - 51,8\%, DJIA - 49\%, CAC40 - 44,8\%.

W horyzontach dwudziestoletnich najbezpieczniejsze były indeksy: FTSE i DAX (68,3 i 67,9\%), pozostałe były mniej bezpieczne NIKKEI 225 (62,5\%), DJIA (51,9\%), CAC 40 (48,7\%).

Horyzonty dwudziestopięcioletnie najbardziej sprzyjały redukcji ryzyka względnego indeksowi DAX (78,3\%); indeksy: NIKKEI 225 i FTSE miały porównywalny poziom przedmiotowego parametru (75,9 i 75,8\%), jak również porównywalnie redukowały ryzyko względne indeksy: CAC 40 i DJIA $(58,9$ i $58,7 \%)$.

W trzydziestoletnich horyzontach inwestycyjnych najbezpieczniejszymi okazały się DAX i FTSE (86,1 i 85,5\%), a następnie NIKKEI 225 (80,2\%), CAC 40 (74\%) oraz DIJA, (70,5\%.)

W pięcioletnich horyzontach najlepsza dynamika redukcji ryzyka względnego realnych stóp zwrotu charakteryzuje indeks DJIA; dla horyzontów 10-20 lat najbezpieczniejszy okazał się indeks FTSE. Dla indeksu DAX najlepszymi okazały się horyzonty 25-30 lat. Dla horyzontów 5-20 lat najmniejszą dynamikę redukcji ryzyka względnego zanotował indeks CAC 40, a w horyzontach 25-30 lat indeks DJIA.

\section{Bibliografia}

Allen, R. (2011). Global economic history: a very short introduction. Oxford: Oxford University Press.

Alpert, P. (1951). Twentieth century economic history of Europe. New York: Henry Schuman, cop.

Arestis, Ph., Sobreira, R. i Oreirp José, J.L. (2011). An assessment of the global impact of the financial crisis. Basingstoke: Palgrave Macmillan.

Arrighi, G. (2010). The long twentieth century: money, power and the origins of our Times. London: New York Verso, cop.

Bairoch, P. (1993). Economics and world history: myths and paradoxes. Chicago: University of Chicago Press, cop.

Bernholz, P. (2003). Monetary regimes and inflation: history, economic and political relationships. Cheltenham; Northampton: Edward Elgar.

Bordo, M. (2012). Deep recessions, fast recoveries, and financial crises: evidence from the American record. Cambridge, Massachusetts: National Bureau of Economic Research.

Budd, C.H. (2011). Finance at the threshold: rethinking the real and financial economies. Farnham, England Burlington: Gower.

Cassis, Y. (2011). Crises and opportunities (1890-2010): the shaping of modern finance. Oxford: Oxford University Press.

Clark, G.A. (2007). Farewell to alms: a brief economic history of the world. Princeton; Oxford: Princeton University Press, cop. 
Eichengreen, B. (2012). The world economy after the global crisis: a new economic order for the 21st century. Singapore: World Scientific Publishing.

Ferguson, N. (2008). The ascent of money: a financial history of the world. New York: Penguin Press.

Flandreau, M., Holtfrerich, C-L. i James H. (2003). International financial history in the twentieth century: system and anarch. Washington: German Historical Institute; Cambridge: Cambridge University Press, cop.

Fridson, M.S. (1998). It was a very good year: extraordinary moments in stock market history. New York: John Wiley and Sons.

Giersch, H.A. (1978). European look at the world economy. Kiel: Universität Kiel.

Glossner, C.L. (2010). The making of the German post-war economy: political communication and public reception of the social market economy after World War II. London; New York: Tauris Academic Studies, cop.

Greasley, D. (2011). Economics and history: surveys in cliometrics. Chichester: Wiley-Blackwell.

Haug, A.A. i Dewald W.G. (2004). Long-term effects of monetary growth on real and nominal variables, major industrial countries, 1880-2000. Frankfurt am Main: European Central Bank.

Kindleberger, C.P. i Laffargue J.P. (2008). Financial crises: theory, history, and Policy. Cambridge: Cambridge University Press; Paris: Editions de la Maison des Sciences de l'Homme.

Littlewood, J. (1998). The stock market: 50 years of capitalism at work. London: Financial Times.

Maddison, A. (2000). Monitoring the world economy 1820-1992. Paris: Organisation for Economic Co-operation and Development.

Mishkin, F.S. (2002). US stock market crashes and their aftermath: implications for monetary policy. Cambridge, Massachusetts: National Bureau of Economic Research.

Mosk, C. (2008). Japanese economic development: markets, norms, structures. London; New York: Routledge.

Pomfret, R.W.T. (2011). The age of equality: the twentieth century in economic perspective. Cambridge, Massachusetts; London: Belknap Press of Harvard University Press.

Quennouëlle-Corre, L. i Cassis, Y. (2011). Financial centres and international capital flows in the nineteenth and twentieth centuries. Oxford: Oxford University Press.

Read, C. (2010). The rise and fall of an economic empire: with lessons for aspiring economies. Basingstoke: Palgrave Macmillan.

Rhode, P.W. (2006). The global economy in the 1990s: a long-run perspective. Cambridge: Cambridge University Press, cop.

Rivoire, J. (1980). L'économie mondiale depuis 1945. Paris: Presses Universitaires de France.

Rockoff, H. (2003). Deflation, silent runs, and bank holidays, in the Great Contraction. Cambridge, Massachusetts: National Bureau of Economic Research.

Schröter, H.G. (2005). Americanization of the European economy: a compact survey of American economic influence in Europe since the 1880s. Dordrecht: Springer, cop.

Silver, M. (1995). Economic structures of antiquity. Westport, Connecticut; London: Greenwood Press, cop.

Vickers, D. (2011). The day after the dollar crashes: a survival guide for the rise of the New World Order. Hoboken, New Jersey: John Wiley and Sons.

World Bank (2010). Global economic prospects: crisis, finance, and growth. Washington: World Bank.

www.globafinancialdata.com.

www.world-exchange.org. 


\title{
Rozdział IX
}

GRZEGORZ PERCZAK ${ }^{*}$

\section{Zastosowanie rozkładu NIG w modelowaniu danych finansowych przy wykorzystaniu dodatkowych informacji o cenach minimalnych i maksymalnych ${ }^{1}$}

\begin{abstract}
Streszczenie
Praca zawiera propozycje modyfikacji modeli GARCH, które zostały skonstruowane nie tylko na podstawie cen zamknięcia, lecz także na podstawie informacji o dobowych minimach i maksimach cen. Jako warunkowy rozkład składnika losowego przyjęto rozkład NIG.

Zakładając, że dzienne stopy zwrotu są zmiennymi losowymi o warunkowym rozkładzie normalnym odwrotnym gaussowskim, zaproponowano rozkład łączny wektorów losowych, którego współrzędnymi są zmienne losowe wartości minimalnej, maksymalnej i końcowej logarytmicznych stóp zwrotu. Rozkład ten został następnie wykorzystany do konstrukcji funkcji wiarygodności służących do estymacji parametrów modeli. Ceny minimalne i maksymalne zastosowane zostały również w modelach do estymacji dziennej wariancji stóp zwrotu. W tym celu wykorzystano nowe propozycje estymatorów wariancji.

Estymacja zaproponowanych parametryzacji modeli GARCH przeprowadzana jest na podstawie szerszego, na ogół ogólnie dostępnego, zbioru informacji o cenach instrumentów finansowych, co powoduje, że modele te lepiej opisują finansowe szeregi czasowe.
\end{abstract}

Słowa kluczowe: rozkład NIG, rozkład łączny, model GARCH, estymatory zrealizowanego zakresu zmian, ceny otwarcia/maksymalne/minimalne/zamknięcia.

* Mgr inż. Grzegorz Perczak - Uniwersytet Mikołaja Kopernika w Toruniu; e-mail: grzegorz.perczak@gmail.com.

1 Praca została sfinansowana ze środków Narodowego Centrum Nauki projekt numer 2012/05/B/HS4/00675 nt. „Modelowanie i prognozowanie zmienności - wykorzystanie dodatkowych informacji o cenach minimalnych i maksymalnych”. Artykuł jest rozszerzeniem i kontynuacją badań przedstawionych w pracach: Perczak (2013) oraz Perczak, Fiszeder (2014) 


\begin{abstract}
The paper includes propositions of modifications of GARCH models, which are formulated on the basis of not only closing prices but also of information about daily minimum and maximum prices. The NIG distribution is used as the conditional distribution of the innovation.

Assuming that the day returns are random variables with the conditional NIG distribution, the joint distribution of random vector of minimum, maximum and finish values of logarithmic returns is proposed. This distribution is then applied in the formulation of likelihood functions used to the estimation of models parameters. Low and high prices are also applied in models to the estimation of daily variance of returns. For this purpose new proposals of variance estimators are used.

The estimation of proposed parameterisations of GARCH models is performed for wider, usually generally available, set of information about prices of financial instruments, that is why presented models better describe financial time series.
\end{abstract}

Keywords: NIG distribution, joint distribution, GARCH model, range-based volatility estimation, open/high/low/close/prices.

\title{
Wstęp
}

Zmienność jest jednym z ważniejszych pojęć współczesnych finansów. Znaczenie zmienności wynika zarówno z teorii finansów, jak i z licznych zastosowań praktycznych. Wyniki badań empirycznych wskazują, że rozszerzanie istniejących już modeli zmienności i formułowanie kolejnych parametryzacji, dążących do coraz lepszego dopasowania modelu do danych empirycznych jest mniej efektywne niż wykorzystanie informacji powszechnie dostępnych na rynku (zob np. Fiszeder 2009). Do niedawna modele parametryczne stosowane do opisu zmienności konstruowane były wyłącznie na podstawie cen zamknięcia. Dodatkowe dane rynkowe, które można uwzględnić przy konstrukcji modeli zmienności można umownie podzielić na dwie grupy: 1) dane o częstotliwości wyższej niż dzienna, czyli tzw. dane intraday, które są zbiorem uporządkowanych par zawierających wartość ceny i czas jej odnotowania; 2) informacje o minimalnych i maksymalnych cenach, w tym przypadku nie jest jednak odnotowywany moment ani nawet kolejność ich wystąpienia.

Zastosowanie danych o częstotliwości wyższej niż dzienna (tzw. notowań wysokiej częstotliwości) wiąże się jednak z koniecznością pokonania szeregu problemów, takich jak: 1) dostępność i koszt nabycia danych; 2) duża złożoność obliczeniowa prowadzonych analiz; 3) mikrostruktura rynku (zob. Doman 2011), trudności z szacowaniem zmienności, których źródłem są silne wahania cykliczne notowań w ciągu dnia, autokorelacja, „szokowy” wpływ informacji makroekonomicznych na notowania. 
Celem niniejszego opracowania jest zaproponowanie parametryzacji modelu GARCH, które będą spełniały następujące warunki: 1) dodatkowe informacje o cenach minimalnych i maksymalnych zostaną wykorzystane zarówno przy estymacji dziennej wariancji, jak i przy konstrukcji funkcji wiarygodności służącej do estymacji parametrów modelu GARCH; 2) w modelu zostanie zastosowana autorska propozycja bardziej efektywnego estymatora dziennej wariancji stóp zwrotu; 3) modele będą w stanie opisać asymetrię i kurtozę warunkowego rozkładu dziennych stóp zwrotu; 4) przyjęte modele będą oszczędnie sparametryzowane; nie zostaną wprowadzone dodatkowe parametry w stosunku do standardowych parametryzacji modelu GARCH.

Niniejszy artykuł jest rozszerzeniem wyników przedstawionych w pracy Perczaka (2013).

\section{Gęstość rozkładu łącznego minimum, maksimum i wartości końcowej arytmetycznego ruchu Browna}

Dla standardowego procesu Wienera $B_{\tau}, \tau \geq 0$ zdefiniowany zostaje ruch Browna $X_{\tau}=\mu \tau+\sigma^{2} B_{\tau}$ oraz ustalona wartość $s>0$. Niech $A_{s}$, i $C_{s}$, będą zmiennymi losowymi zdefiniowanymi następująco: $A_{s}=\min _{0<\tau \leq s} X_{\tau}$ i $C_{s}=\max _{0<\tau \leq s} X_{\tau}$. Wartość procesu w punkcie $s$ jest zmienną losową, dla której zachodzi $X_{s} \sim N\left(\mu s, \sigma^{2} s\right)$. Przedstawiane zagadnienie ilustruje rysunek 1.

Ry s u n e 1. Wartość minimalna $A_{s}$, maksymalna $C_{s}$ i końcowa $X_{s}$, osiagnnięte przez ruch Browna w chwili $s$

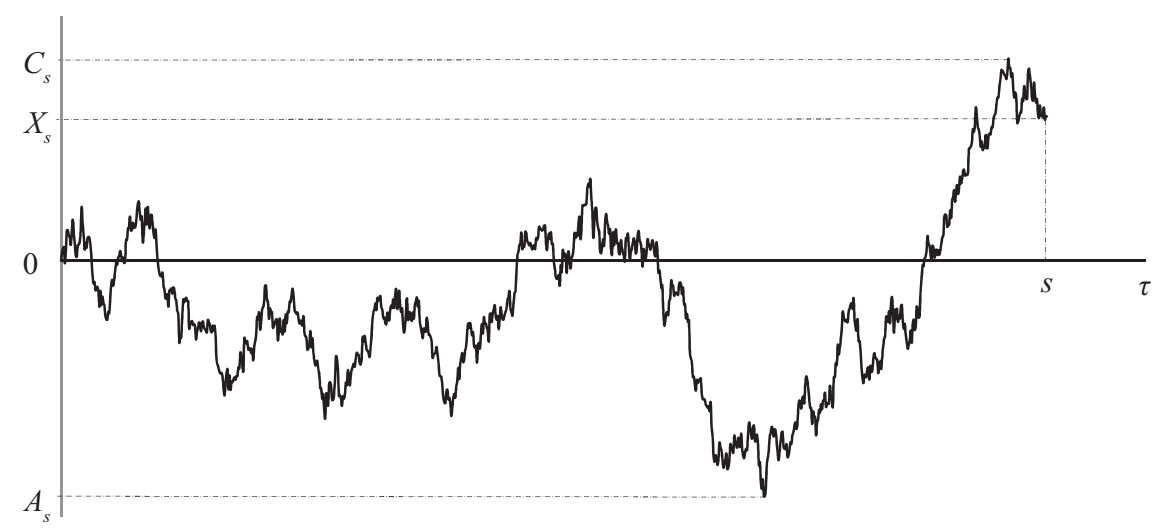

Źródło: opracowanie własne. 
Gęstość $f_{A C N}\left(a, c, x ; \mu s, \sigma^{2}, s\right)$ rozkładu łącznego wektora zmiennych losowych $\left(A_{s}, C_{s}, X_{s}\right)$ przedstawia równanie (zob. Perczak i Fiszeder 2013):

$$
\begin{aligned}
f_{A C N}\left(a, c, x ; \mu s, \sigma^{2} s\right) & =\frac{1}{\sqrt{2 \pi \sigma^{5} s^{\frac{5}{2}}}} \sum_{k=-\infty}^{k=\infty}\left(g\left(a, c, x ; k, k, \mu, \sigma^{2}, s\right)-\right. \\
& \left.-\left(a, c, x ; k, k+1, \mu, \sigma^{2}, s\right)\right),
\end{aligned}
$$

gdzie funkcja $g$ opisana jest zależnością:

$$
\begin{gathered}
g\left(a, c, x ; k_{1}, k_{2}, \mu, \sigma^{2}, s\right)=4 k_{1} k_{2}\left(\left(x-2\left(c k_{2}-a k_{1}\right)\right)^{2}-\right. \\
\left.-\sigma^{2} s\right) e^{\frac{2(c k 2-a k) \mu s-(x-2(c k 2-a k)-\mu s)^{2}}{2 \sigma^{2} s}} .
\end{gathered}
$$

Wektor losowy $\left(A_{s}, C_{s}, X_{s}\right)$ ma rozkład łączny $A C N\left(\mu s, \sigma^{2} s\right)$, jeśli jego gęstość opisana jest wzorem (1).

\subsection{Podstawowe własności rozkładów odwrotnego gaussowskiego IG oraz normalnego odwrotnego gaussowskiego NIG}

Zmienna losowa $X$ ma rozkład odwrotny gaussowski, oznaczany jako $I G(\delta, \gamma)$ (Inverse Gaussian) z parametrami $0<\delta$ i $0 \leq \gamma$, jeżeli jej gęstość rozkładu prawdopodobieństwa $f_{I G}(x, \delta, \gamma)$ określona dla $x>0$ jest postaci podanej przez Barndorffa-Nielsena (1997, s. 2, równanie 2.5):

$$
f_{I G}(x ; \delta, \gamma)=\frac{\delta}{\sqrt{2 \pi}} x^{-\frac{3}{2}} \exp \left(\delta \gamma-\frac{\delta^{2} x^{-1}+\gamma^{2} x}{2}\right) .
$$

Funkcja charakterystyczna tej zmiennej ma postać:

$$
\varphi_{I G}(u ; \delta, \gamma)=E\left[e^{i u X}\right]=e^{\delta\left(\gamma-\sqrt{\gamma^{2}-2 i u}\right)} .
$$

Stąd wartość oczekiwana i wariancja równe są odpowiednio:

$$
E[X]=\frac{\delta}{\gamma}, \operatorname{Var}[X]=\frac{\delta}{\gamma^{3}} .
$$

Wszystkie momenty zmiennej $X$ mają wartości skończone. Dla dowolnej dodatniej stałej $s$ zachodzą równoważności: 


$$
X \sim I G(\delta, \gamma) \Leftrightarrow s X \sim I G(\delta \sqrt{s}, \gamma / \sqrt{s})
$$

oraz

$$
s X \sim I G(\delta, \gamma) \Leftrightarrow X \sim I G(\delta / \sqrt{s}, \gamma \sqrt{s})
$$

Rysunki 2 i 3 przedstawiają wykresy funkcji gęstości rozkładów odwrotnych gaussowskich $I G(\delta, \gamma)$ dla wybranych wartości parametrów $\delta$ i $\gamma$. Wszystkie wykresy na rysunku 2 zawierają przykłady funkcji gęstości rozkładów o wartości oczekiwanej równej 1, natomiast wykresy na rysunku 3 przedstawiają wybrane funkcje gęstości rozkładów o wariancji równej 1 . Wpływ grubości „ogona” zmiennej losowej o rozkładzie $I G(\delta, \gamma)$ na wartość wariancji tej zmiennej losowej nie został na tym rysunku dobrze uwidoczniony. $\mathrm{Z}$ tego powodu wykresy funkcji z rysunku 3 zostały powielone na rysunku 4, lecz na tym ostatnim zastosowano logarytmiczną skalę na osi pionowej oraz poszerzono zbiór argumentów na osi poziomej.

Rys u nek 2. Wykresy funkcji gęstości wybranych zmiennych losowych o rozkładzie odwrotnym gaussowskim $I G(\delta, \gamma)$, których wartość oczekiwana jest równa 1

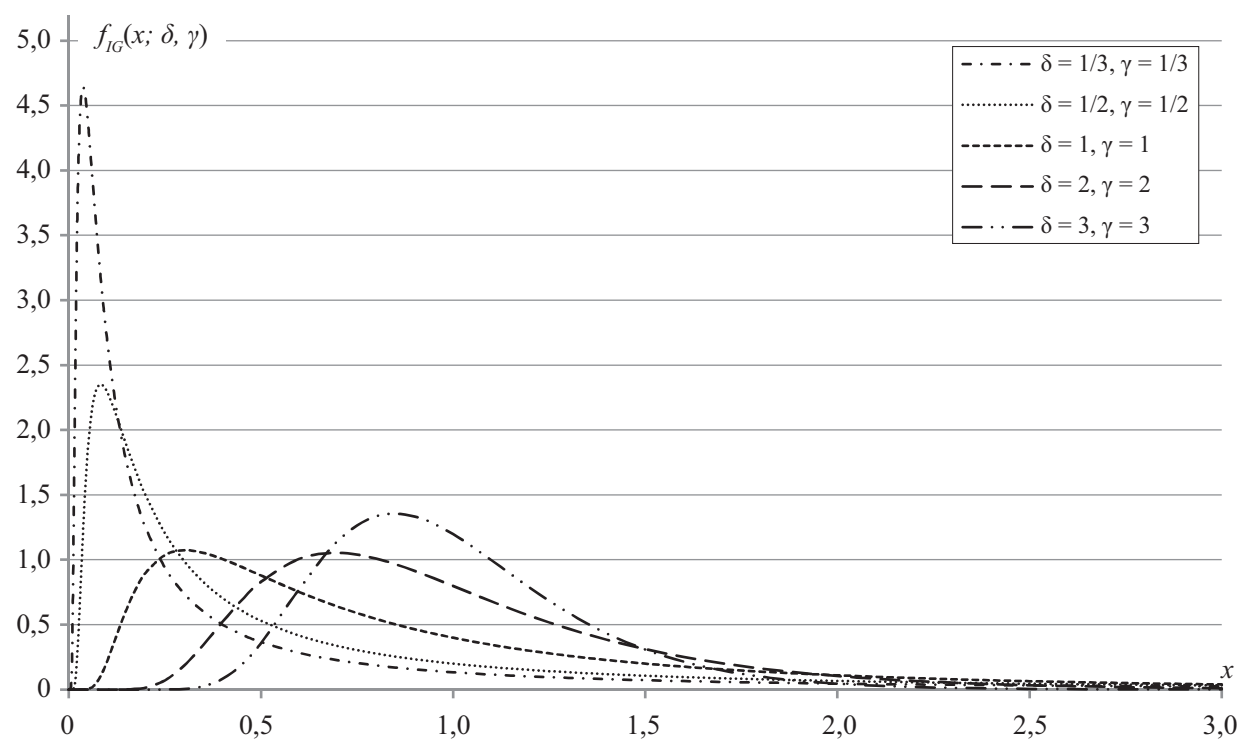

Źródło: opracowanie własne. 
Rysunek 3. Wykresy funkcji gęstości wybranych zmiennych losowych o rozkładzie odwrotnym gaussowskim $I G(\delta, \gamma)$, których wariancja jest równa 1

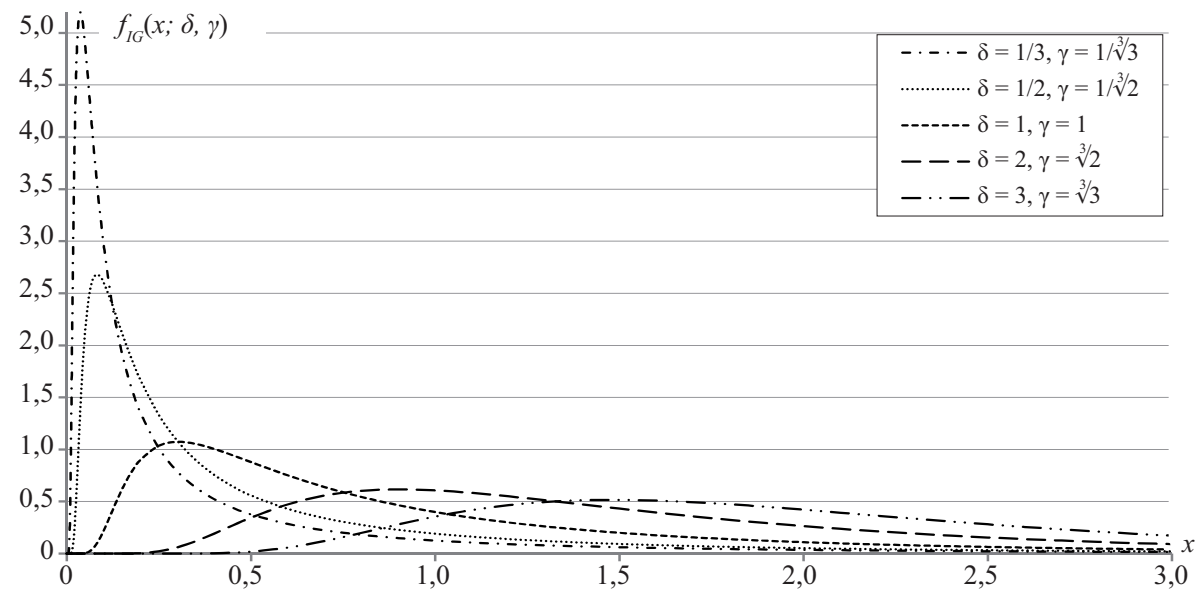

Źródło: opracowanie własne.

Rysunek 4. Wykresy funkcji gęstości wybranych zmiennych losowych o rozkładzie odwrotnym gaussowskim $I G(\delta, \gamma)$, których wariancja jest równa 1 (wartości funkcji przedstawiono w skali logarytmicznej)

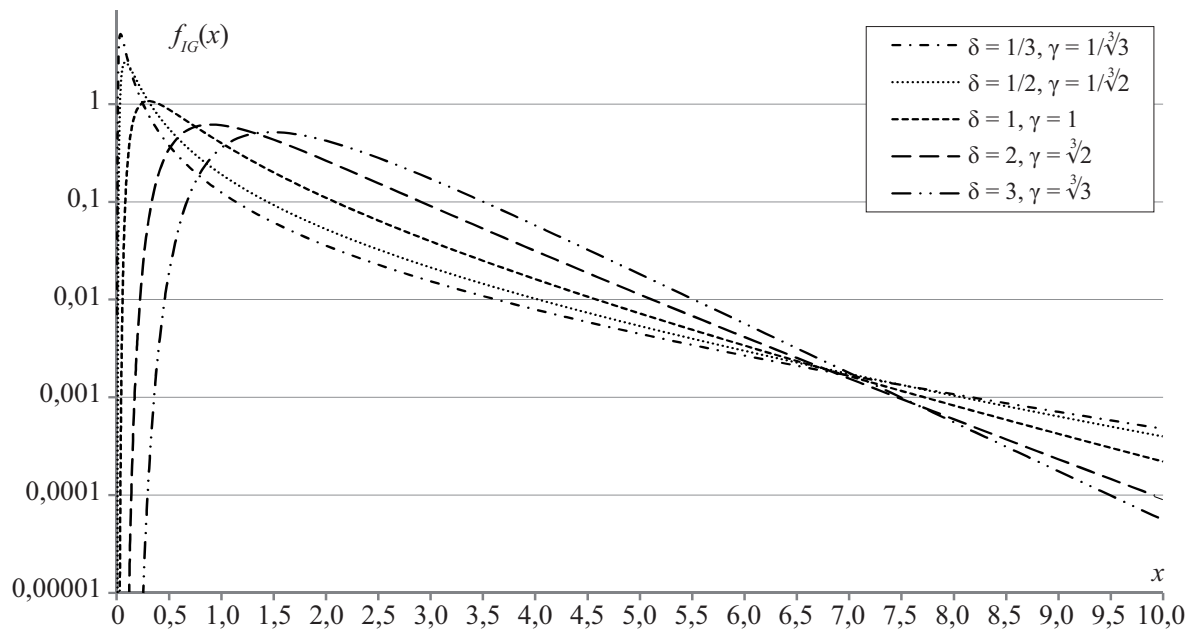

Źródło: opracowanie własne. 
Zmienna losowa $X$ ma rozkład $N I G(\alpha, \beta, \delta, \mu)$ z parametrami $0 \leq \alpha$, $-\alpha \leq \beta \leq \alpha, O<\delta$, i $\mu \in R$, jeżeli $X \mid W \sim \mathrm{N}(\mu+\beta W, W)$, gdzie $W \sim I G(\delta, \gamma)$ oraz $\gamma=\sqrt{\alpha^{2}-\beta^{2}}$.

Gęstość rozkładu prawdopodobieństwa tej zmiennej ma zatem postać (zob. Barndorff-Nielsen 1997, s. 2, równanie 2.1):

$$
\begin{gathered}
f_{N I G}(x ; \alpha, \beta, \delta, \mu)=\int_{0}^{\infty} f_{N}(x ; \mu+\beta w, w) f_{I G}(w ; \delta, \gamma) d w= \\
=\frac{\alpha \delta e^{\beta(x-\mu)+\delta \gamma}}{\pi \sqrt{\delta^{2}+(x-\mu)^{2}}} K_{1}\left(\alpha \sqrt{\delta^{2}+(x-\mu)^{2}}\right),
\end{gathered}
$$

gdzie $f_{N}\left(x ; \mu, \sigma^{2}\right)=\frac{1}{\sqrt{2 \pi}} e^{\frac{-(x-\mu)^{2}}{2 \sigma^{2}}} \operatorname{oraz} K_{\lambda}(z)=\frac{1}{2} \int_{0}^{\infty} y^{\lambda-1} \exp \left(-\frac{1}{2} z\left(y+\frac{1}{y}\right)\right) d y$.

Wartość współczynnika koncentracji rozkładu $N I G$ jest nie mniejsza od wartości współczynnika koncentracji rozkładu normalnego. Rozkład NIG nadaje się zatem do opisu rozkładów o grubych ogonach. Ponadto, zmienna losowa o rozkładzie NIG ma wszystkie momenty skończone. Oznacza to, że ogony tego rozkładu nie są „tak grube”, jak w przypadku rozkładu t-Studenta. W porównaniu z tym ostatnim, rozkład $N I G$ nadaje się zatem lepiej do opisu rozkładów logarytmicznych zwrotów instrumentów finansowych w sytuacjach, gdy znajomość tych rozkładów służy do wyceny instrumentów pochodnych.

Na rysunkach 5 i 6 przedstawiono wykresy funkcji gęstości rozkładów normalnych odwrotnych gaussowskich $N I G$ dla wybranych wartości parametrów $\alpha, \beta, \delta, \mu$. Dla porównania dodatkowo dołączono wykres funkcji gęstości rozkładu normalnego i t-Studenta o 3 stopniach swobody, co oznacza, że tylko pierwsze dwa momenty tego ostatniego rozkładu mają wartości skończone. Wartości oczekiwane i wariancje każdego rozkładu na obu rysunkach są równe odpowiednio 0 i 1 . Na rysunku 6 zastosowano logarytmiczną skalę.

J.H. Venter i P.J. de Jongh (2004) badali użyteczność stosowania różnych typów rozkładów do opisu innowacji w celu uzyskania efektywnej estymacji parametrów modelu GARCH. Doszli do konkluzji, że stosowanie rozkładu $N I G$ daje bardzo konkurencyjne efekty względem stosowania innych rozkładów, w tym także względem skośnego rozkładu t-Studenta. Zalecają, aby „W większości przypadków” rozkład NIG rutynowo stosować w praktyce, co uczynione zostanie także w niniejszym opracowaniu. W tym celu wygodniejsze 
Ry s u n e 5. Wykresy funkcji gęstości wybranych zmiennych losowych o wartości oczekiwanej równej 0 i wariancji równej 1

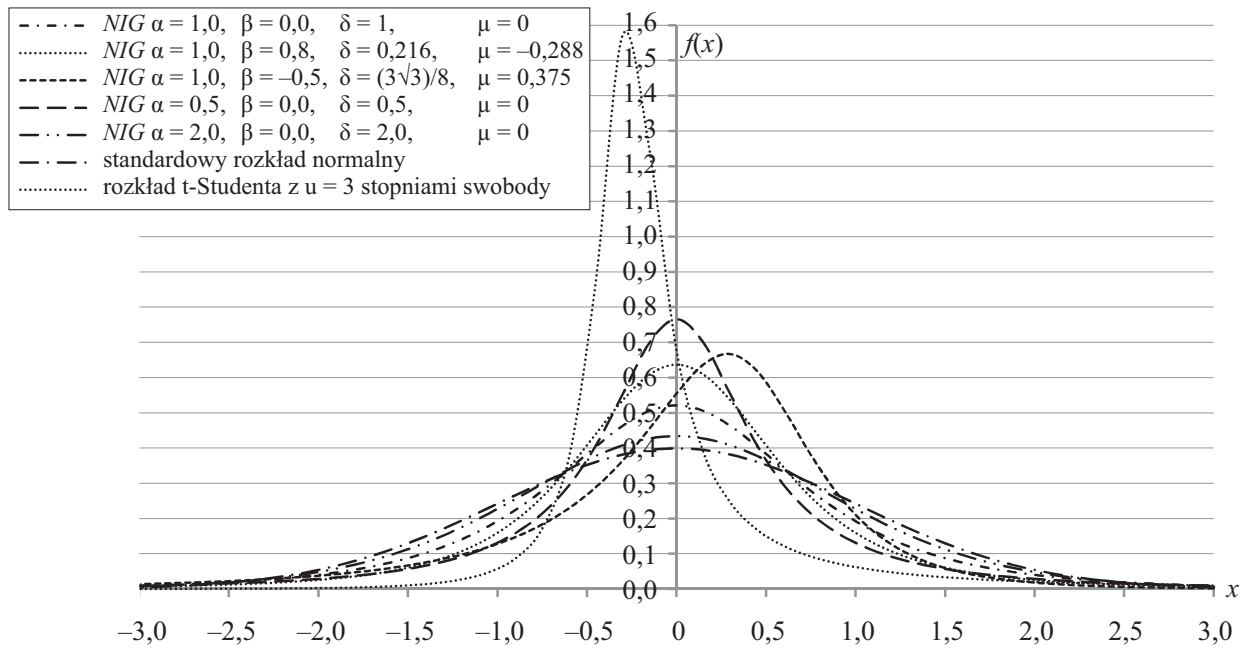

Źródło: opracowanie własne.

Ry s u n e k. Wykresy z rysunku 5 przedstawione w skali logarytmicznej

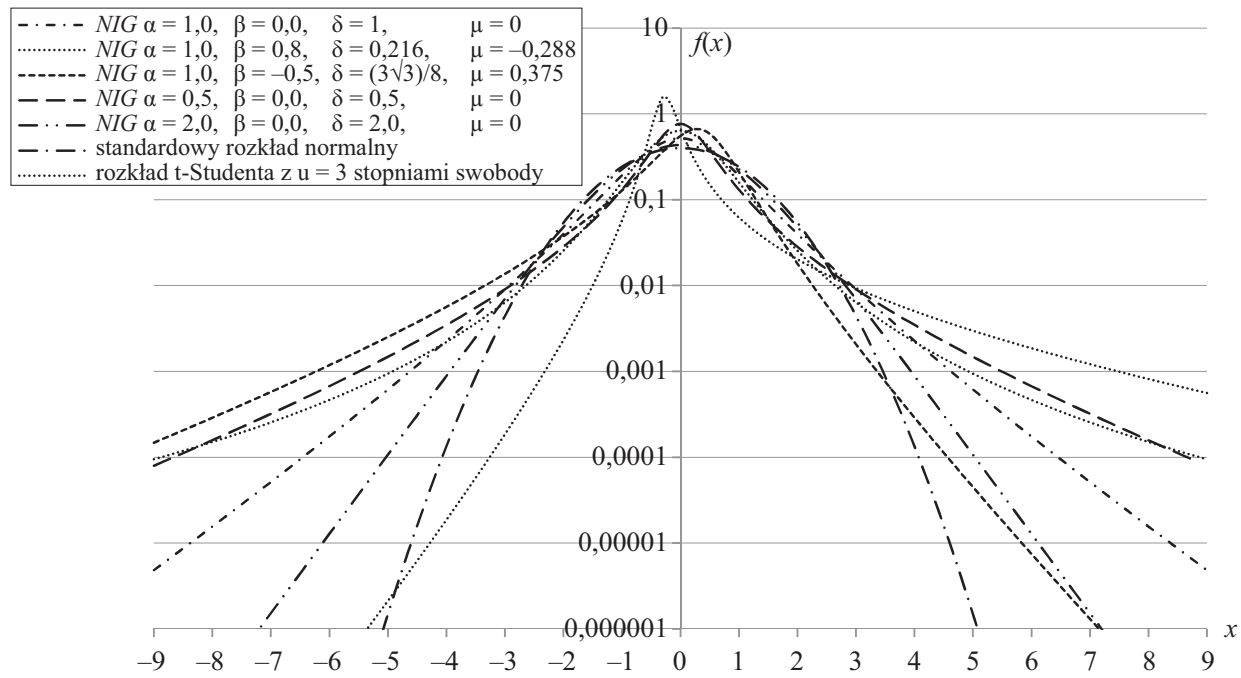

Źródło: opracowanie własne. 
będzie jednak zastosowanie nieco innej parametryzacji tego rozkładu, przedstawionej poniżej.

Zmienna losowa $X$ ma rozkład $N I G(\bar{\alpha}, \bar{\beta}, \delta, \mu)$, jeśli jej funkcja gęstości rozkładu prawdopodobieństwa dana jest formułą (zob. Barndorff-Nielsen 1997, s. 2, równanie 2.4; Jensen i Lunde 2001, s. 324):

$$
f_{N G}(x ; \overline{\alpha, \bar{\beta}, \delta, \mu})=\frac{\bar{\alpha} e^{\bar{\beta}\left(\frac{x-\mu}{\delta}\right)+\bar{\gamma}}}{\pi \delta \sqrt{1+\left(\frac{x-\mu}{\delta}\right)^{2}}} K_{1}\left(\bar{\alpha} \sqrt{1+\left(\frac{x-\mu}{\delta}\right)^{2}}\right) .
$$

Wartość oczekiwana i wariancja tej zmiennej dane są odpowiednio formułami:

$$
E[X]=\mu+\frac{\bar{\beta} \delta}{\bar{\gamma}}, \quad \operatorname{Var}[X]=\frac{\overline{\alpha^{2}} \delta^{2}}{\bar{\gamma}^{3}} .
$$

Z punktu widzenia potrzeb niniejszej pracy, użyteczną zaletą tej parametryzacji jest fakt, że tylko dwa parametry, tj. $\bar{\alpha} \mathrm{i} \bar{\beta}$, jednoznacznie determinują wartości współczynników asymetrii i koncentracji:

$$
A[X]=\frac{3 \bar{\beta}}{\bar{\alpha} \sqrt{\bar{\gamma}}}, \quad K[X]=3+\frac{3}{\bar{\gamma}}\left(1+4\left(\frac{\bar{\beta}}{\bar{\alpha}}\right)^{2}\right) .
$$

\subsection{Proces BIG}

Rozkład NIG można przedstawić w postaci mieszaniny wariancji i średniej rozkładu gaussowskiego z rozkładem mieszającym, za który przyjmuje się rozkład odwrotny gaussowski (por. Weron i Weron 1998, s. 288). Formalnie, oznacza to, że jeżeli $0<\gamma, 0<\delta, \mu \in R, \beta \in R, Z \sim N(0,1)$ i $W \sim I G(\delta, \gamma)$, wówczas zmienna losowa $X \mid W=\mu+\beta W+\sqrt{W} Z \operatorname{ma} \operatorname{rozkład} N(\mu+\beta W, W)$ a stąd oraz z równania (7) wynika, że $X \sim N I G(x ; \alpha, \beta, \delta, \mu)$ dla $\alpha=\sqrt{\beta^{2}+\gamma^{2}}$ (por. Barndorff-Nielsen i Shephard 2001, s. 15).

Przedstawiona w poprzednim akapicie zależność może być wykorzystana do opisu własności nowego procesu stochastycznego. Niech $0<s, 0<\gamma$, $0<\delta$ będą ustalonymi parametrami, dla których określona zostaje zmienna losowa $Y \sim I G(\delta \sqrt{s}, \gamma \sqrt{s})$. Z relacji opisanych w formule (6) wynika, że dla zmiennej $W=s Y$ zachodzi $W \sim I G(\delta s, \gamma)$. Niech $B_{\tau}$ będzie standardowym procesem Wienera. Zdefiniowany zostaje proces, którego warunkową wartość w chwili $\tau$ opisuje równanie: 


$$
X_{\tau} \mid Y=\mu \tau+\beta Y \tau+\sqrt{Y} B_{\tau}, \mu \in R, \beta \in R
$$

Dla dowolnej wartości $\tau$, wielkość $X_{\tau}$ jest zmienną losową o warunkowym rozkładzie normalnym: $X_{\tau} \mid Y \sim N(\mu \tau+\beta Y \tau, Y \tau)$. W punkcie $\tau$ równym ustalonej wartości s zachodzi związek: $X_{\mathrm{s}} \mid Y \sim N(\mu s+\beta Y s, Y s)=N(\mu s+\beta W, W)$. Stąd $X_{s} \sim N I G(\alpha, \beta, \delta s, \mu s)$.

Należy podkreślić, że bezwarunkowy rozkład zmiennej $X_{\tau}$ jest znany tylko dla $\tau=s$. Dla innych wartości $\tau$ rozkład ten nie jest znany. Ogólnie, nie są także znane rozkłady przyrostów tego procesu. Wartość parametru $s$ ma zatem istotne znaczenie przy opisie omawianego procesu.

Zdefiniowany proces $X_{\tau}$ zostanie nazwany procesem BIG (Brownian Inverse Gaussian). Opisana powyżej jego specyfikacja jest modyfikacją procesu opisanego przez J.H. Ventera, P.J. de Jongha i G. Griebenowa (2006, s. 102, wzór 6).

\subsection{Gęstość rozkładu łącznego stóp zwrotu minimum, maksimum i wartości końcowej procesu BIG}

Niech $X_{\tau}$ będzie procesem $B I G$ zdefiniowanym w równaniu (11) dla ustalonych parametrów $0<s, 0<\gamma, 0<\delta, \mu \in R, \beta \in R$. Zdefiniowane zostają ponadto $A_{s}=\min _{0<\tau \leq s} X_{\tau}$ i $C_{s}=\max _{0<\tau \leq s} X_{\tau}$. Korzystając z wzoru (7), wyznaczono gęstość rozkładu łącznego wektora zmiennych losowych $\left(A_{s}, C_{s}, X_{s}\right)$ w punkcie o współrzędnych $(a, c, x)$ :

$$
\begin{gathered}
f_{A C N I G}(a, c, x ; \alpha, \beta, \delta s, \mu s)=\int_{0}^{\infty} f_{A C N}(a, c, x ; \mu s+\beta y s, y s) f_{I G}(y s ; \delta s, \gamma) d(y s)= \\
=\sum_{k=-\infty}^{k=\infty} \frac{4 \alpha^{2} \delta s k^{2} e^{\beta(x-\mu s)+\delta s \gamma}}{\pi}\left(\alpha \theta_{1} \frac{K_{1}\left(\alpha \sqrt{\theta_{1}+\vartheta}\right)}{\left(\theta_{1}+\vartheta\right)^{\frac{3}{2}}}+\left(3 \theta_{1}-\vartheta\right)^{2} \frac{K_{2}\left(\alpha \sqrt{\theta_{1}+\vartheta}\right)}{\left(\theta_{1}+\vartheta\right)^{2}}\right)- \\
-\sum_{k=-\infty}^{k=\infty} \frac{4 \alpha^{2} \delta s k(k+1) e^{\beta(x-\mu s)+\delta s \gamma}}{\pi}\left(\alpha \theta_{2} \frac{K_{1}\left(\alpha \sqrt{\theta_{2}+\vartheta}\right)}{\left(\theta_{2}+\vartheta\right)^{\frac{3}{2}}}+\right. \\
\left.+\left(3 \theta_{2}-\vartheta\right)^{2} \frac{K_{2}\left(\alpha \sqrt{\theta_{2}+\vartheta}\right)}{\left(\theta_{2}+\vartheta\right)^{2}}\right)
\end{gathered}
$$

gdzie: $\theta_{1}=(2 k(c-a)-x)^{2}, \quad \theta_{2}=(2 c+2 k(c-a)-x)^{2}, \quad \vartheta_{1}=\delta^{2} s^{2}+(x-\mu s)^{2}-x^{2}$.

Wektor losowy $\left(A_{s}, C_{s}, X_{s}\right)$ będzie miał rozkład oznaczony jako $A C N I G$, tj. $\left(A_{s}, C_{s}, X_{s}\right) \sim A C N I G(\alpha, \beta, \delta s, \mu s)$, jeżeli jego gęstość będzie określona 
równaniem (12). Oczywiście, współrzędna $X_{s}$ wektora $\left(A_{s}, C_{s}, X_{s}\right)$ o rozkładzie $A C N I G(\alpha, \beta, \delta s, \mu s)$ ma rozkład brzegowy $X_{s} \sim N I G(\alpha, \beta, \delta s, \mu s)$.

Podobnie jak miało to miejsce w przypadku rozkładu $N I G$, przyjmując podstawienie $\bar{\alpha}=\alpha \delta s, \quad \bar{\beta}=\beta \delta s, \quad \bar{\gamma}=\sqrt{\bar{\alpha}^{2}-\bar{\beta}^{2}}$, możliwe jest określenie dla rozkładu $A C N I G$ alternatywnej parametryzacji $A C N I G(\bar{\alpha}, \bar{\beta}, \delta s, \mu s)$. Wymaga to dokonania stosunkowo prostych przekształceń wzoru (12):

$$
\begin{gathered}
f_{A C N I G}(a, c, x ; \bar{\alpha}, \bar{\beta}, \delta s, \mu s)= \\
=\sum_{k=-\infty}^{k=\infty} \frac{4 \bar{\alpha}^{2} k^{2} e^{\bar{\beta}\left(\frac{x-\mu s}{\delta s}\right)+\bar{\gamma}}}{\pi \delta s}\left(\frac{\bar{\alpha}}{\delta s} \theta_{1} \frac{K_{1}\left(\frac{\bar{\alpha}}{\delta s} \sqrt{\theta_{1}+\vartheta}\right)}{\left(\theta_{1}+\vartheta\right)^{\frac{3}{2}}}+\left(3 \theta_{1}-\vartheta\right)^{2} \frac{K_{2}\left(\frac{\bar{\alpha}}{\delta s} \sqrt{\theta_{1}+\vartheta}\right)}{\left(\theta_{1}+\vartheta\right)^{2}}\right)- \\
-\sum_{k=-\infty}^{k=\infty} \frac{4 \bar{\alpha}^{2} k(k+1) e^{\bar{\beta}\left(\frac{x-\mu s}{\delta s}\right)+\bar{\gamma}}}{\pi \delta s}\left(\frac{\bar{\alpha}}{\delta s} \theta_{2} \frac{K_{1}\left(\frac{\bar{\alpha}}{\delta s} \sqrt{\theta_{2}+\vartheta}\right)}{\left(\theta_{2}+\vartheta\right)^{\frac{3}{2}}}+\right. \\
\left.+\left(3 \theta_{2}-\vartheta\right)^{2} \frac{K_{2}\left(\frac{\bar{\alpha}}{\delta s} \sqrt{\theta_{2}+\vartheta}\right)}{\left(\theta_{2}+\vartheta\right)^{2}}\right)
\end{gathered}
$$

gdzie: $\theta_{1}=(2 k(c-a)-x)^{2}, \quad \theta_{2}=(2 c+2 k(c-a)-x)^{2}, \quad \vartheta_{1}=\delta^{2} s^{2}+(x-\mu s)^{2}-x^{2}$.

Wektor losowy $\left(A_{s}, C_{s}, X_{s}\right)$ będzie miał rozkład oznaczony jako $A C N I G$, tj. $\left(A_{s}, C_{s}, X_{s}\right) \sim A C N I G(\bar{\alpha}, \bar{\beta}, \delta s, \mu s)$, jeżeli jego gęstość będzie określona równaniem (13).

Analogicznie, współrzędna $X_{s}$ wektora $\left(A_{s}, C_{s}, X_{s}\right)$ o rozkładzie $A C N I G(\bar{\alpha}, \bar{\beta}, \delta s, \mu s)$ ma rozkład brzegowy $X_{s} \sim N I G(\bar{\alpha}, \bar{\beta}, \delta s, \mu s)$.

\subsection{Estymacja wariancji procesu BIG na podstawie stóp zwrotu minimum, maksimum i wartości końcowej}

Na podstawie dotychczasowych ustaleń zachodzi implikacja:

$$
\begin{gathered}
\mathrm{W} \sim \mathrm{IG}(\delta s, \gamma) \wedge\left(A_{s}, C_{s}, X_{s}\right) \mid W \sim A C N(\mu s+\beta W, W) \\
\Downarrow \\
\left(A_{s}, C_{s}, X_{s}\right) \sim A C N I G(\alpha, \beta, \delta s, \mu s) .
\end{gathered}
$$

Estymator Rogersa-Satchella (1991) jest nieobciążonym estymatorem wariancji ruchu Browna (zob. Perczak i Fiszeder 2013): 


$$
\left(A_{s}, C_{s}, X_{s}\right) \mid W \sim A C N(\cdot, W) \Rightarrow E\left[C_{s}\left(C_{s}-X_{s}\right)+A_{s}\left(A_{s}-X_{s}\right) \mid W\right]=W .
$$

Czyli:

$$
\begin{aligned}
E\left[C_{s}\left(C_{s}-X_{s}\right)\right. & \left.+A_{s}\left(A_{s}-X_{s}\right)\right]=E\left[E \left[C_{s}\left(C_{s}-X_{s}\right)+\right.\right. \\
& \left.\left.+A_{s}\left(A_{s}-X_{s}\right) \mid W\right]\right]=E[W]=\frac{\delta s}{\gamma} .
\end{aligned}
$$

Zatem, estymator postaci:

$$
\hat{V}(s)=\frac{\alpha^{2}}{\gamma^{2}}\left(C_{s}\left(C_{s}-X_{s}\right)+A_{s}\left(A_{s}-X_{s}\right)\right)=\frac{\bar{\alpha}^{2}}{\bar{\gamma}^{2}}\left(C_{s}\left(C_{s}-X_{s}\right)+A_{s}\left(A_{s}-X_{s}\right)\right)
$$

ma wartość oczekiwaną równą (patrz formuły przedstawione w 9):

$$
E[\hat{V}(s)]=\frac{\alpha^{2}}{\gamma^{2}} \frac{\delta s}{\gamma}=\frac{\alpha^{2} \delta s}{\gamma^{3}}=\frac{\bar{\alpha}^{2} \delta^{2} s^{2}}{\bar{\gamma}^{3}}=\operatorname{Var}\left[X_{s}\right]
$$

a to oznacza, że jest on nieobciążonym estymatorem wariancji wartości przyjmowanej przez proces $B I G$ w punkcie $s$.

\section{Model GARCH z warunkowym rozkładem NIG składnika losowego konstruowany na podstawie rozszerzonego zbioru danych}

W dalszej części opracowania proces $B I G$ zostanie wykorzystany do opisu wewnątrzdziennego procesu logarytmicznych stóp zwrotu instrumentu. Parametr $s$ będzie równy jednostce, za którą zostanie przyjęty czas pomiędzy zamknięciami notowań rynkowych w dwóch kolejnych dniach.

Przez $S_{t, \tau}$ oznaczana będzie cena instrumentu finansowego odnotowana w kolejnym dniu notowań $t(t \in N, 0<t)$ po upływie czasu $\tau(0 \leq \tau \leq 1)$ od ostatniego notowania poprzedniego dnia. Zachodzi zatem tożsamość: $S_{t-1,1}=S_{t, 0}$. Przez pojęcie ,wewnątrzdziennej stopy zwrotu w chwili $\tau$ w dniu $t$ " rozumiana będzie wartość $X_{t, \tau}=\ln \left(S_{t, \tau} / S_{t, 0}\right.$. Przyjęte zostaje założenie, że dla $0 \leq \tau \leq 1$ wielkość $X_{t, \tau}$ jest procesem $B I G$. Ponieważ zakładamy także, że $s=1$, w związku z tym $X_{t, 1}$ jest zmienną losową o rozkładzie NIG. Parametry tego rozkładu zostaną przedstawione poniżej przy pełnej prezentacji modelu.

Dodatkowo przyjęto odpowiednio definicje minimalnej dziennej, maksymalnej dziennej i jednodniowej (wartości końcowej dziennej) stopy zwrotu: 
$A_{t, 1}=\min _{0 \leq \tau \leq 0} \ln \left(S_{t, \tau} / S_{t, 0}\right), C_{t, 1}=\max _{0 \leq \tau \leq 0} \ln \left(S_{t, \tau} / S_{t, 0}\right)$ i $X_{t, 1}=\ln \left(S_{t, 1} S_{t, 0}\right)$. Dla uproszczenia oznaczeń ustalone zostanie, że: $A_{t}:=A_{t, 1}, C_{t}:=C_{t, 1}, X_{t}:=X_{t, 1}$. Wykorzystywane informacje dotyczące dziennych notowań instrumentu finansowego reprezentowane będą teraz przez uporządkowaną trójkę liczb $\left(a_{t}, c_{t}, x_{t}\right)$ zamiast pojedynczej wartości $x_{t}$, jak ma to miejsce w klasycznym modelu GARCH.

Model NIG-S\&ARCH (NIG stochastic and autoregressive conditional heteroskedasticity) został wprowadzony przez M.B. Jensena i A. Lundego (2001). Jego postać, rozszerzoną o równanie autoregresyjne oraz ogólną specyfikacje modelu GARCH, można przedstawić w formie następujących równań:

$$
\begin{gathered}
X_{t} \mid \mathfrak{I}_{t-1} \sim N I G\left(\bar{\alpha}, \bar{\beta}, \frac{\bar{\gamma}^{3 / 2}}{\bar{\alpha}} \sqrt{h_{t}, \mu_{t}}\right), \\
\mu_{t}=\phi_{0}+\sum_{i=1}^{r} \phi_{i} X_{t-1}, \\
\varepsilon_{t}=X_{t}-\mu_{t}-\frac{\bar{\beta} \sqrt{\bar{\gamma}}}{\bar{\alpha}} \sqrt{h_{t}}, \\
h_{t}=\omega_{0}+\sum_{i=1}^{q} \omega_{i} \varepsilon_{t-i}^{2}+\sum_{i=1}^{p} \xi_{i} h_{t-i} .
\end{gathered}
$$

W tak skonstruowanym modelu zmienna $\varepsilon_{t}$ ma następujące własności:

$$
\begin{gathered}
\varepsilon_{t} \mid \mathfrak{J}_{t-1} \sim N I G\left(\bar{\alpha}, \bar{\beta}, \frac{\bar{\gamma}^{3 / 2}}{\bar{\alpha}} \sqrt{h_{t}},-\frac{\bar{\beta} \sqrt{\gamma}}{\bar{\alpha}}\right), E\left[\varepsilon_{t} \mid \mathfrak{I}_{t-1}\right]=0 \\
\mathrm{i} \operatorname{Var}\left[\varepsilon_{t} \mid \mathfrak{J}_{t-1}\right]=h_{t} .
\end{gathered}
$$

Parametry tego modelu mogą być estymowane za pomocą MNW na podstawie funkcji wiarygodności z wykorzystaniem wyłącznie cen zamknięcia:

$$
\begin{aligned}
& \{\hat{\alpha}, \hat{\beta}, \hat{\boldsymbol{\omega}}, \hat{\boldsymbol{\xi}}, \hat{\boldsymbol{\varphi}}\}=\underset{\bar{\alpha}, \bar{\beta}, \omega, \xi, \varphi}{\arg \max } \ln L_{N I G}(\bar{\alpha}, \bar{\beta}, \boldsymbol{\omega}, \boldsymbol{\xi}, \boldsymbol{\varphi})= \\
& =\underset{\bar{\alpha}, \bar{\beta}, \omega, \xi, \varphi}{\arg \max } \sum_{t=1}^{n} \ln f_{N I G}\left(x_{t} ; \bar{\alpha}, \bar{\beta}, \frac{\bar{\gamma}^{3 / 2}}{\bar{\alpha}} \sqrt{h_{t}(\omega, \boldsymbol{\xi})}, \mu_{t}(\varphi)\right),
\end{aligned}
$$


gdzie $\omega=\left(\omega_{0}, \omega_{1}, \ldots \omega_{q}\right), \boldsymbol{\xi}=\left(\xi_{1}, \xi_{2}, \ldots \xi_{p}\right), \varphi=\left(\varphi_{0}, \varphi_{2}, \ldots \varphi_{r}\right)$, funkcja fNIG została zaś przedstawiona w równaniu (8). Model ten określany będzie w dalszej części pracy jako AR-S\&GARCH-NIG i oznaczany $N_{11}$.

Do konstrukcji nowych parametryzacji modelu AR-S\&GARCH-NIG zostaną wykorzystane dodatkowe informacje o cenach minimalnych i maksymalnych. W pierwszej kolejności anulowane jest ustalenie przyjęte w równaniu (18). W jego miejsce definiowany będzie rozkład wektora losowego:

$$
\left(A_{t}, C_{t}, X_{t}\right) \mid \mathfrak{I}_{t-1} \sim A C N I G\left(\bar{\alpha}, \bar{\beta}, \frac{\bar{\gamma}^{3 / 2}}{\bar{\alpha}} \sqrt{h_{t}}, \mu_{t}\right) .
$$

Dalej proces wykorzystania dodatkowych informacji przebiegać będzie w dwóch niezależnych kierunkach:

1) przez zastąpienie formuły ustalania składnika losowego przyjętej w równaniu (20) estymatorem wariancji przedstawionym w formule (16), tj.

$$
\varepsilon_{t}^{2}=\frac{\bar{\alpha}^{2}}{\bar{\gamma}^{2}}\left(C_{t}\left(C_{t}-X_{t}\right)+\left(A_{t}-X_{t}\right)\right),
$$

2) przez anulowanie sposobu estymacji parametrów opisanej równaniem (22) i przyjęcie w zamian, że parametry modelu mogą być estymowane za pomocą MNW na podstawie funkcji wiarygodności konstruowanej $\mathrm{z}$ wykorzystaniem cen minimalnych, maksymalnych i zamknięcia:

$$
\begin{gathered}
\{\hat{\bar{\alpha}}, \hat{\boldsymbol{\beta}}, \hat{\boldsymbol{\omega}}, \hat{\boldsymbol{\xi}}, \hat{\boldsymbol{\varphi}}\}=\underset{\bar{\alpha}, \boldsymbol{\beta}, \boldsymbol{\omega}, \xi, \boldsymbol{\varphi}}{\arg \max } \ln L_{A C N I G}(\bar{\alpha}, \overline{\boldsymbol{\beta}}, \boldsymbol{\omega}, \boldsymbol{\xi}, \boldsymbol{\varphi})= \\
=\underset{\overline{\alpha, \beta, \omega, \xi, \varphi}}{\arg \max } \sum_{t=1}^{n} \ln f_{A C N I G}\left(\alpha_{t}, c_{t}, x_{i} ; \bar{\alpha}, \bar{\beta}, \frac{\bar{\gamma}^{3 / 2}}{\bar{\alpha}} \sqrt{h_{t}(\boldsymbol{\omega}, \boldsymbol{\xi})}, \mu_{t}(\boldsymbol{\varphi})\right) .
\end{gathered}
$$

W efekcie zostaną zaproponowane trzy nowe parametryzacje: $N_{12}, N_{21}, N_{22}$, które wraz z parametryzacją opisanego już modelu $N_{11}$ przedstawia tabela 1.

W modelu $N_{11}$ przedstawiona w równaniu (20) wartość składnika losowego $\varepsilon_{t}$ jest równa $X-E\left[X_{t} \mid \mathfrak{J}_{t-1}\right]$. Wartość ta ustalona jest w sposób typowy dla modeli GARCH. Kwadrat składnika losowego $\varepsilon_{t}^{2}=\left(X-E\left[X_{t} \mid \mathfrak{I}_{t-1}\right]\right)^{2}$, który jest wykorzystany w równaniu (21) do obliczenia wartości długoterminowej wariancji $h_{t}$, można interpretować jako estymator zrealizowanej wariancji procesu wewnątrzdziennej stopy zwrotu w dniu $t$. Estymator ten ustalony jest na podstawie jedynej dostępnej informacji dotyczącej realizacji tego procesu: wartości jednodniowego zwrotu $X_{t}$. 
Ta be la 1. Opis parametryzacji modeli przedstawionych w opracowaniu

\begin{tabular}{|l|c|c|c|c|}
\hline Oznaczenie modelu & $N_{11}$ & $N_{12}$ & $N_{21}$ & $N_{22}$ \\
\hline Nazwa modelu & $\begin{array}{c}\text { AR-S\&GARCH- } \\
\text {-NIG }\end{array}$ & $\begin{array}{c}\text { AR-S\&GARCH- } \\
\text {-NIG z OHLC }\end{array}$ & $\begin{array}{c}\text { AR-S\&GARCH- } \\
\text {-HL-NIG }\end{array}$ & $\begin{array}{c}\text { AR-S\&GARCH- } \\
\text {-HL-NIG } \\
\text { z OHLC }\end{array}$ \\
\hline $\begin{array}{l}\text { Równanie opisujące } \\
\text { rozkład stóp zwrotu }\end{array}$ & $(18)$ & $(23)$ & $(23)$ & $(23)$ \\
\hline Równanie AR & $(19)$ & $(19)$ & $(19)$ & $(19)$ \\
\hline $\begin{array}{l}\text { Równanie opisujące } \\
\text { sposób definiowania } \\
\text { składnika losowego }\end{array}$ & $(20)$ & $(24)$ & $(20)$ & $(24)$ \\
\hline Równanie GARCH & $(21)$ & $(21)$ & $(21)$ & $(21)$ \\
\hline $\begin{array}{l}\text { Równanie opisujące } \\
\text { sposób estymacji } \\
\text { parametrów }\end{array}$ & $(22)$ & $(22)$ & $(25)$ & $(25)$ \\
\hline
\end{tabular}

Źródło: opracowanie własne.

Najgłębszą modyfikacją modelu $N_{11}$ jest model $N_{22}$. Zrezygnowano w nim z przedstawionej w równaniu (20) formuły ustalenia składnika losowego $\varepsilon_{t}$. Kwadrat jego wartości nadal jest jednak interpretowany jako estymator zrealizowanej wariancji procesu wewnątrzdziennej stopy zwrotu w dniu $t$. Korzystając z faktu, że wartości minimalnej dziennej $A_{t}$ i maksymalnej dziennej $C_{t}$ stopy zwrotu są znane, zastosowano bardziej efektywny estymator przedstawiony w równaniu (24). Ponadto, funkcja wiarygodności, jaka została skonstruowana w modelu $N_{22}$, wykorzystuje dodatkową znajomość cen minimalnych i maksymalnych, uwzględniając przy tym zależności pomiędzy wszystkimi współrzędnymi wektora losowego $\left(A_{t}, C_{t}, X_{t}\right)$.

\section{Analiza empiryczna zmienności indeksu WIG i kursu USD/PLN}

Przedstawione w pracy propozycje parametryzacji modeli GARCH zostały zastosowane do szacowania zmienności indeksu rynku akcji WIG notowanego na GPW w Warszawie oraz kursu walutowego USD/PLN notowanego na międzynarodowym rynku walutowym FOREX. Analizę przeprowadzono dla 10-letniego okresu od 30 września 2002 r. do 28 września 2012 r., czyli odcinka czasu obejmującego zarówno okresy hossy, jak i bessy, a także, co jest istotne, kryzysu finansowego. Dla obu instrumentów wyznaczono wektory dziennych stóp zwrotu: $\left(a_{1}, c_{1}, x_{1}\right),\left(a_{2}, c_{2}, x_{2}\right), \ldots,\left(a_{n}, c_{n}, x_{n}\right)$. Długości 
badanych szeregów czasowych stóp zwrotu wynosiły $n=2513$ oraz $n=2571$ odpowiednio dla indeksu WIG i kursu USD/PLN.

W badaniu zastosowano cztery parametryzacje modeli GARCH przedstawionych w częściach trzeciej: $N_{11}, N_{12}, N_{21}, N_{22}$. Zarówno dla indeksu WIG, jak i kursu walutowego nie zaobserwowano istotnej statystycznie autokorelacji stóp zwrotu, przyjęto zatem, że $r=0$, tzn. $\mu_{t}=\phi_{0}$. Rzędy opóźnień $p$ i $q$ w modelach GARCH ustalono na podstawie kryterium informacyjnego Schwarza. Dla modelu $N_{11}$ dla indeksu WIG wybrano $p=1$ i $q=3$ (dla porównania zamieszczono również wyniki dla opóźnień równych jeden), we wszystkich pozostałych przypadkach natomiast $p=1$ i $q=1$. Do estymacji parametrów modeli zastosowano metodę największej wiarygodności. Jak to zostało już wcześniej przedstawione, parametry modeli $N_{11}, N_{12}$ estymowano na podstawie logarytmu funkcji wiarygodności ln $L_{N I G}$. Jednakże dla celów informacyjnych podano także wartości ln $L_{A C N I G}$. Analogicznie, parametry modeli $N_{21}, N_{22}$ szacowano, maksymalizując wartości $\ln L_{A C N I G}$, a dla celów informacyjnych podano także wartości $\ln L_{N I G}$. Dodatkowo dla każdego modelu podano również wartości kryterium informacyjnego Schwarza obliczone dla obu funkcji wiarygodności. Otrzymane wyniki zostały zaprezentowane w tabeli 2.

Wszystkie obliczenia wykonano za pomocą samodzielnie napisanych kodów źródłowych w języku $\mathrm{C}++$, wykorzystując bibliotekę obliczeń numerycznych GSL (http://www.gnu.org/software/gsl/).

Analizując rezultaty przedstawione w tabeli 2, można stwierdzić, że:

1) zastosowanie estymatorów dziennej wariancji (równanie 24) konstruowanych na podstawie danych o cenach minimalnych i maksymalnych w miejsce „standardowo" zdefiniowanego składnika losowego (równanie 20) obniża (tzn. poprawia) zazwyczaj wartości in $L_{A C N I G}$;

2) estymacja parametrów dla indeksu WIG na podstawie funkcji wiarygodności wykorzystującej ceny minimalne i maksymalne lepiej opisuje zjawisko asymetrii;

3) wykorzystanie do estymacji informacji o minimalnych i maksymalnych cenach powoduje zmiany ocen parametrów w modelu GARCH; zwiększają się na ogól oceny parametru $\omega_{1}$, zmniejszają się oceny $\xi_{1}$, oraz zmniejsza się suma ocen $\omega_{1}+\xi_{1}$ w porównaniu do modelu GARCH szacowanego na podstawie cen zamknięcia; ma to istotne znaczenie z punktu widzenia zarówno modelowania, jak i prognozowania zmienności; oznacza to bowiem, że wpływ zmian w poprzednim okresie na bieżącą zmienność jest większy, a zatem jest szybsza reakcja na zmieniającą się sytuację rynkową według modelu, do którego estymacji zastosowano również ceny 


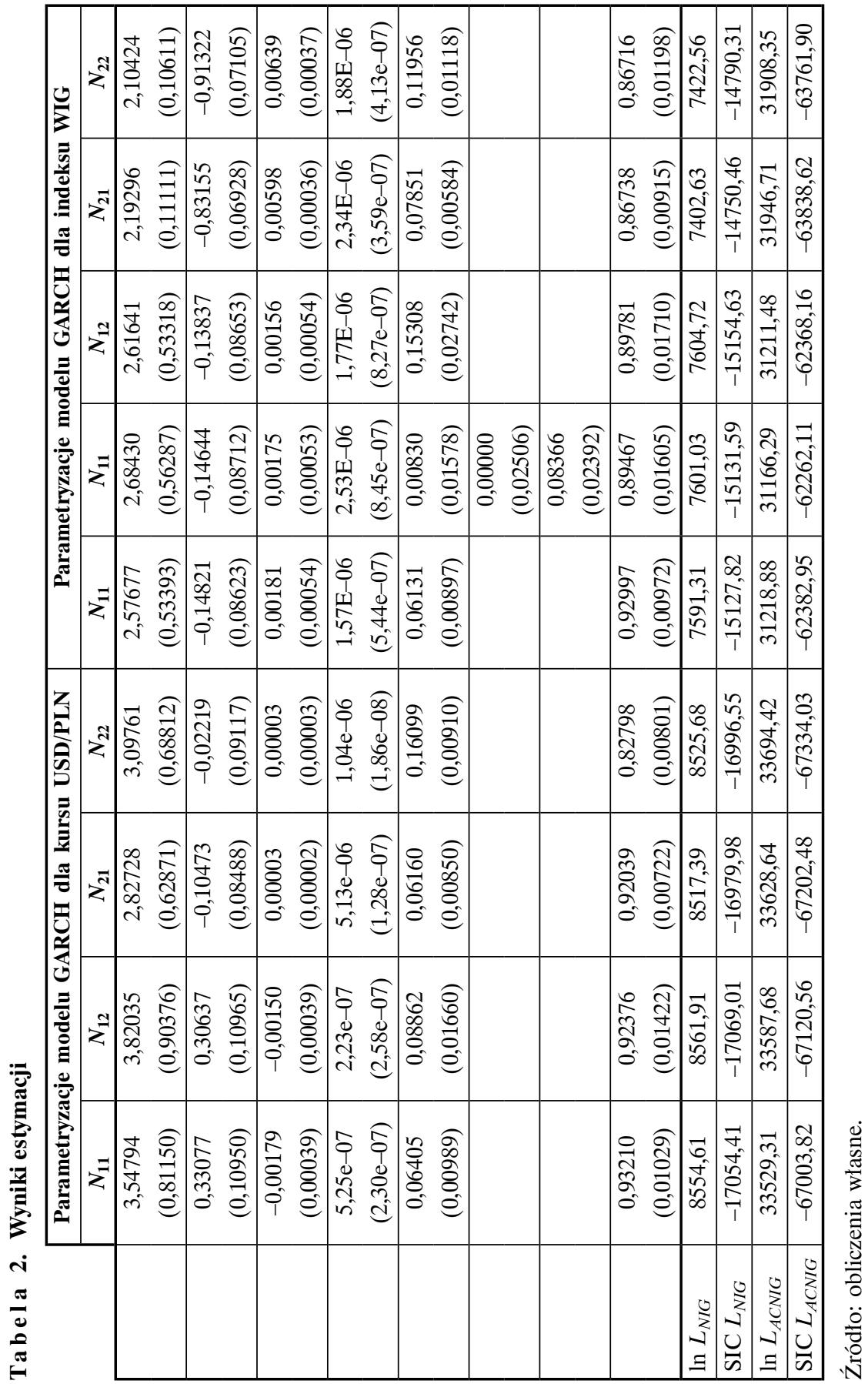


minimalne i maksymalne; ponadto, zjawiska szokowe mają bardziej krótkotrwały wpływ na zmienność niż wynikałoby to z modelu GARCH szacowanego na podstawie wyłącznie cen zamknięcia, co było w wyraźnej opozycji do wyników uzyskiwanych na przykład na podstawie zmienności implikowanej (zob. np. Engle i Mustafa 1992). Właśnie to zastrzeżenie było dotychczas wymieniane jako jedna $\mathrm{z}$ największych słabości modeli GARCH. Wydaje się zatem, że dzięki zastosowaniu danych o cenach minimalnych i maksymalnych do estymacji parametrów modelu uzyskuje się oceny, które są bliższe prawdziwym parametrom.

\section{Podsumowanie}

W pracy zaprezentowano propozycje parametryzacji modeli GARCH, które zostały skonstruowane nie tylko na podstawie cen zamknięcia, lecz także na podstawie informacji o dobowych minimach i maksimach cen. Zakładając, że procesy śróddziennych stóp zwrotu są procesem o warunkowym rozkładzie $N I G$, przedstawiono rozkłady łączne wektorów losowych, których współrzędnymi są zmienne losowe wartości minimalnej, maksymalnej i końcowej logarytmicznych stóp zwrotu.

Modyfikacja tradycyjnego modelu GARCH przeprowadzona została w dwóch odrębnych kierunkach:

1) poprzez zastosowanie autorskiego bardziej efektywnego estymatora dziennej wariancji skonstruowanego na podstawie stóp zwrotu minimum, maksimum i zamknięcia;

2) poprzez wykorzystanie do estymacji parametrów modeli funkcji wiarygodności skonstruowanych na podstawie wspomnianych funkcji gęstości łącznych rozkładów wektorów losowych.

Wszystkie propozycje modeli GARCH są oszczędnie sparametryzowane i mają tę samą liczbę parametrów, co tradycyjny model GARCH ze składnikiem losowym opisanym warunkowym rozkładem skośnym t-Studenta. Pomimo wykorzystania danych z notowań wewnątrzdziennych, modele konstruowane są na podstawie danych o częstotliwości dziennej, tzn. na podstawie szeregów wektorów stóp zwrotu minimum, maksimum i wartości końcowej. Pozwala to uniknąć problemów związanych z analizą danych o bardzo wysokiej częstotliwości.

Dzięki wykorzystaniu dodatkowych informacji o cenach minimalnych i maksymalnych: 
1) skonstruowano funkcje wiarygodności, które wykorzystują znacznie szerszy zbiór danych rynkowych opisujących instrumenty finansowe, w efekcie uzyskuje się znacząco większe wartości funkcji wiarygodności;

2) szacunki zmienności uzyskiwane na podstawie zaprezentowanych modeli mają własności bliższe tym, jakie obserwuje się na podstawie analizy innych metod, np. zmienności implikowanej; stosowanie klasycznych modeli GARCH i wyłącznie cen zamknięcia może zatem prowadzić do błędów poznawczych.

Można przypuszczać, że wykorzystanie dodatkowych danych w procesie estymacji parametrów modelu GARCH pozwoli na konstrukcję trafniejszych prognoz zmienności w porównaniu z modelami, których parametry estymowane są na podstawie tylko cen zamknięcia, wymaga to jednak przeprowadzenia dodatkowych badań. Dostępność notowań rynkowych w postaci cen minimum, maksimum na równi z cenami zamknięcia daje nadzieję, na powszechne stosowanie zaprezentowanych modeli w przyszłości.

\section{Bibliografia}

Andersson, J. (2001). On the normal inverse Gaussian stochastic volatility model, Journal of Business and Economic Statistics, 19, 44-54.

Barndorff-Nielsen, O.E. (1977). Exponentially decreasing distributions for the logarithm of particle size, Proceedings of the Royal Society London, Series A, 353, 401-419.

Barndorff-Nielsen, O.E. (1995). Normal Inverse Gaussian Processes and the Modelling of Stock Returns, Research Report 300, Department of Theoretical Statistics, University of Aarhus.

Barndorff-Nielsen, O.E. (1997). Normal Inverse Gaussian Distributions and Stochastic volatility Modelling, Scandinavian Journal of Statistics, 24(1), 1-13.

Barndorff-Nielsen, O.E. i Shephard, N. (2001). Modelling by Lévy Processes for Financial Econometrics. W: O.E. Barndorff-Nielsen, T. Mikosch, S. Resnick (red.), Lévy Processes - Theory and Applications. Boston: Birkhauser, 283-318.

Bollerslev, T. (1986). Generalised Autoregressive Conditional Heteroskedasticity, Journal of Econometrics, 31, 307-327.

Bollerslev, T. (1987). A conditional heteroscedastic time series model for speculative prices and rates of return, Review of Economics and Statistics, 69, 542-547.

Cox, D.R. i Miller, M.D. (1965). The theory of stochastic processes. London: Methuen and Co.

Diebold, F.X. (1986). Modelling the Persistence of Conditional Variances: A Comment, Econometric Reviews, 5, 51-56.

Doman, M. (2011). Mikrostruktura giełd papierów wartościowych. Poznań: Wydawnictwo Uniwersytetu Ekonomicznego w Poznaniu.

Engle, R.F. i Mustafa, C. (1992). Implied ARCH Models from Options Prices, Journal of Econometrics, 52, 289-311. 
Fiszeder, P. (2009). Modele klasy GARCH w empirycznych badaniach finansowych. Toruń: Wydawnictwo UMK.

Forsberg, L. (2002). On the Normal Inverse Gaussian Distribution in Modeling Volatility in the Financial Markets. Doctoral thesis, Studia Statistica Upsaliensia 5, A. Christofferson, K.G. Jöreskog (red.). Uppsala University Library.

Forsberg, L. i Bollerslev, T. (2002). Bridging the gap between the distribution of realized (ECU) volatility and ARCH modelling (of the Euro): the GARCH-NIG model, Journal of Applied Econometrics, 17(5), 535-548.

Jensen, M. B. i Lunde, A. (2001). The NIG-S \& ARCH model: a fat tailed, stochastic, and autoregressive conditional heteroscedastic volatility model, Econometrics Journal, 4, 319-342.

Li, A. (1998). The pricing of double barrier options and their variations, Advances in Futures and Options Research, 10.

Lildholdt, P.M. (2002). Estimation of GARCH models based on open, close, high, and low prices, Working paper 128, Centre for Analytical Finance, Aarhus School of Business.

Osiewalski, J. i Pipień, M., Bayesian Forecasting of Foreign Exchange Rates Using GARCH Models with Skewed $t$ Conditional Distributions, 25-th International Conference MACROMODELS'98 vol. II, W. Welfe (red.), Łódź 1999, s. 195-218.

Parkinson, M. (1980). The extreme value method for estimating the variance of the rate of return, Journal of Business, 53, 61-68.

Patton, A.J. (2006). Volatility Forecast Comparison Using Imperfect Volatility Proxies, Quantitative Finance Research Centre, Research Paper 175. Sydney: University of Technology.

Perczak, G. (2013). Zastosowanie rozkładu NIG w modelowaniu danych finansowych przy wykorzystaniu dodatkowych informacji o cenach minimalnych i maksymalnych, II Kongres Rynku Kapitałowego, Krajowy Depozyt Papierów Wartościowych SA i Wydział Zarządzania Uniwersytetu Warszawskiego, Warszawa.

Perczak, G. i Fiszeder, P. (2013). Estymacja wariancji arytmetycznego ruchu Browna na podstawie znanych wartości minimum, maksimum, końcowej oraz dryfu, Przeglad Statystyczny, 60(1).

Perczak, G. i Fiszeder, P. (2014). Model GARCH - wykorzystanie dodatkowych informacji o cenach minimalnych i maksymalnych, Bank $i$ Kredyt (w druku).

Rogers, L.C.G. i Satchell, S.E. (1991). Estimating Variance From High, Low and Closing Prices, The Annals of Applied Probability, 1(4), 504-512.

Venter, J.H. i de Jongh, P.J. (2004). Selecting an innovation distribution for Garch models to improve efficiency of risk and volatility estimation, The Journal of Risk, 6, 27-52.

Venter, J.H., de Jongh, P.J. i Griebenow, G. (2005). NIG-GARCH Models Based on Open, Close, High and Low prices, South African Statistical Journal, 39(2), 79-101.

Venter, J.H., de Jongh, P.J. i Griebenow, G. (2006). GARCH-type volatility models based on Brownian inverse Gaussian intra-day return processes, Journal of Risk, 8(4), 97-116.

Weron, A. i Weron, R. (1998). Inżynieria finansowa. Wycena instrumentów pochodnych. Symulacje komputerowe. Statystyka rynku, Warszawa: Wydawnictwa Naukowo-Techniczne. 


\title{
Rozdział X
}

\author{
SEBASTIAN MAJEWSKI*
}

\section{Wpływ informacji nieekonomicznych na kształtowanie się kursów akcji spółek prowadzących działalność sportową}

\begin{abstract}
Streszczenie
W ostatnich latach sport coraz częściej staje się dziedziną życia, w której zauważa się silne wpływy procesów komercjalizacyjnych. W Europie dotyczy to najbardziej piłki nożnej, gdzie według Raportu Delloitte (2013) przychody dwudziestu największych klubów piłkarskich Europy sięgnęły w 2012 roku blisko 5 miliardów euro. Kluby piłkarskie, ratując się przed trudnościami finansowymi, zaczęły pozyskiwać środki na swoją działalność z publicznej emisji akcji. W tym momencie notowania ich akcji, a przede wszystkim stopy zwrotu stały się bardziej wrażliwe niż inne na oddziaływanie czynników o charakterze nieekonomicznym, takich jak na przykład wyniki meczów czy informacje o transferach zawodników. Artykuł skupia się na badaniu wpływu informacji nieekonomicznych na ceny i stopy zwrotu z akcji. Za przykład empiryczny posłużą dwa walory: ceny akcji BVB (Borussii Dortmund) oraz wartości indeksu Dow Jones Stoxx Football Index.
\end{abstract}

Słowa kluczowe: informacja i efektywność rynku, Giełda Papierów Wartościowych.

\begin{abstract}
In recent years sport is increasingly becoming a part of life, in which the strong influence of the commercialization process is noted. It could be observed generally in Europe in football, where, according to the report of Delloitte, revenues of twenty largest football clubs in Europe in 2012 amounted nearly 5 billion euros. Football clubs trying to avoid financial difficulties began to raise funds for their activities from the public issue of shares. At this point, their prices and rates of return have become more sensitive than others to the effects of non-economic factors, such as results of matches and information on transfers of players. This article is concentrated on the analysis of influence of non-economic information on prices and rates of return of sport
\end{abstract}

Dr hab. Sebastian Majewski - Katedra Ubezpieczeń i Rynków Kapitałowych, Wydział Nauk Ekonomicznych i Zarządzania, Uniwersytet Szczeciński; e-mail: Sebastian. Majewski@wneiz.pl. 
companies. An empirical example in this research is based on two instruments: shares of BVB (Borussia Dortmund) and values of Dow Jones Stoxx Football Index.

Keywords: Information and Market Efficiency, Stock Market.

\section{Wstęp}

Powszechna globalizacja ekonomii dotyczy nie tylko rynków finansowych, o czym można się było przekonać podczas kryzysu finansowego lat 2007-2009, lecz także pozostałych dziedzin życia, w tym również sportu. W przypadku piłki nożnej obserwuje się w ostatnich latach dwa rodzaje procesów o prędkościach: globalnej i lokalnej (Antonowicz, Szlendak i Kossakowski 2012). Oba te procesy przede wszystkim sprzyjają dywergencji między klubami piłkarskimi. Autorzy nie wspominają jednak, że czasami tego typu procesy mają charakter zamierzony. Może wydawać się dziwnym, że władze klubu rezygnują z nowoczesnych źródeł finansowania, przez co z pełną świadomością wybierają lokalną prędkość rozwoju. Przykładem klubu, który zdecydował się na taką drogę jest Athletic Bilbao, jego finansowanie opiera się bowiem na rocznych składkach członkowskich socios, a sam klub przez to podkreśla przywiązanie do tradycji i kultury Basków (Prabucki 2012). Powstaje jednak grupa klubów, których pozycja na rynku zapewnia im ogromne dochody finansowe. Według Raportu Delloitte przychody dwudziestu największych klubów piłkarskich Europy sięgnęły w 2012 r. blisko 5 mld euro. Inna część klubów piłkarskich, ratując się przed trudnościami finansowymi, zdecydowała się na pozyskanie środków finansowych na działalność sportową z publicznej emisji akcji. Od tego momentu notowania akcji tych spółek, a przede wszystkim stopy zwrotu, stały się bardziej wrażliwe niż inne na oddziaływanie czynników o charakterze nieekonomicznym (takich jak na przykład wyniki meczów czy informacje o transferach zawodników).

W artykule zostanie przeprowadzona analiza oddziaływania czynników o charakterze nieekonomicznym na kurs akcji i stopy zwrotu spółki giełdowej BVB oraz indeksu giełdowego klubów piłkarskich Dow Jones Stoxx Football Index (DJ Stoxx FI). W ujęciu, którego dotyczy artykuł, czynnikami nieekonomicznymi są pewne zmienne, których wpływ na zmienną objaśnianą (ekonomiczną) nie mieści się w klasycznych teoriach ekonomicznych. Taka definicja zmiennych jest zbieżna z definicją czynników behawioralnych, podaną w pracy S. Majewskiego (2012). Według klasyfikacji tam przytoczonej, czynniki, o których pisano, mieszczą się w kategorii czynników kulturowych - sportowych. 
Do realizacji postawionego w artykule celu zostaną wykorzystane testy statystyczne sprawdzające istotność różnic w zmianach cen przed i po zajściu zdarzenia, a także modele ekonometryczne typu GARCH (p, q) (Doque i Ferreira 2005; Sarac i Zeren 2013). Celem artykułu jest sprawdzenie czy ceny akcji Borussii Dortmund oraz indeksu giełdowego SEFI są wrażliwe na wyniki sportowe klubu piłkarskiego BVB w rozgrywkach Bundesligi, w rozgrywkach europejskich i meczach towarzyskich oraz inne zdarzenia związane $\mathrm{z}$ funkcjonowaniem tego klubu piłkarskiego. Zatem hipoteza badawcza brzmi następująco: Zdarzenia sportowe, a w szczególności wyniki spotkań piłkarskich mają wpływ na zmiany stóp zwrotu z akcji BVB. Hipotezę tę można rozszerzyć o hipotezę dodatkową mówiącą o tym, że zmiany stóp zwrotu $\mathrm{z}$ indeksu giełdowego DJ Stoxx FI są wrażliwe na zdarzenia sportowe związane z klubem piłkarskim BVB.

\section{Rynek piłki nożnej w Europie}

Na rynek piłkarski w Europie składają się przede wszystkim kluby piłkarskie, których wartość na poziomie najwyższych klas rozgrywkowych wynosi w sumie ponad 20 mld euro, 678 klubów piłkarskich i 18315 zawodników. Ich wartość to ponad $0,2 \%$ PKB całej Unii Europejskiej. Olbrzymia część przychodów przypada niestety dwudziestu największym klubom. Jak podaje Delloitte w swoim raporcie, prawie pięć miliardów euro przychodów z tytułu prowadzenia działalności piłkarskiej przypada jedynie na pięć najbogatszych lig. Są nimi: angielska (1,8 mld euro), hiszpańska ( 1 mld euro), francuska (0,3 mld euro), włoska ( 0,9 mld euro) i niemiecka ( 0,9 mld euro). Przeprowadzenie choćby szczątkowej analizy ekonomicznej prowadzenia działalności piłkarskiej nie jest możliwe ze względu na brak informacji o podstawowej kategorii ekonomicznej, czyli o kosztach. Te z kolei są niezwykle wysokie, co powoduje, że mimo rosnących przychodów część klubów staje się niewypłacalna. Niektóre z nich rozwiązują swoją sytuację przez stworzenie spółki akcyjnej i emisję papierów wartościowych. W takiej sytuacji była kilka lat temu na przykład Borussia Dortmund, która obecnie jest uznawana za jeden z bogatszych klubów na świecie (11 miejsce w rankingu Delloitte). Jednocześnie BVB jest pierwszym klubem piłkarskim - spółką giełdową w Niemczech.

Europejski rynek piłkarski również przez finansistów został oceniony jako niezwykle atrakcyjny, czego dowodem jest powstanie 22 kwietnia 2002 r. indeksu giełdowego Stoxx Europe Football. W skład tego indeksu wchodziły na samym początku 33 spółki akcyjne będące klubami piłkarskimi z Europy i Turcji. Liczba ta zmniejszała się z roku na rok, głównie w wyniku prze- 
jęć przez spółki niepubliczne, by w 2013 r. wynieść 23. Pierwszym w historii klubem piłkarskim, który zdecydował się na debiut na publicznym rynku papierów wartościowych był Tottenham Hotspurs w 1983 r. Wiele innych klubów angielskich zdecydowało się na podobne rozwiązanie, między innymi Manchester United (wycofany z rynku i następnie debiutujący na NYSE) czy Newcastle (przejęty przez spółkę niepubliczną). Jednak skład obecnego indeksu DJ Stoxx FI tworzą jedynie dwa kluby szkockie i nie ma w nim żadnego angielskiego. Pozostałe spółki pochodzą z: Danii (5), Turcji (4), Włoch (3), Portugalii (3), Holandii (1), Francji (1), Niemiec (1), Szwecji (1), Macedonii (1) i Polski (1). Kapitalizacja spółek wchodzących w skład indeksu wynosi w obecnie 537 mln euro. Najważniejszymi komponentami indeksu jest pięć spółek, stanowiących blisko 55\% całego indeksu:

1) Besiktas - 13,74\%,

2) Borussia Dortmund - $11,82 \%$,

3) Parken Sport \& Entertainment - 10,30\%,

4) Juventus - 9,91\%,

5) Fenerbahce Sportif Hizmet - 8,27\%

Kształtowanie się wartości indeksu w latach 2002-2013 przedstawiono na rysunku 1 . Na rysunku można zaobserwować, że indeks ten, podobnie jak cały rynek, zareagował na kryzys finansowy lat 2008-2009 bardzo silnymi spadkami.

$\mathrm{Na}$ kształtowanie się indeksu piłkarskiego wpływ mają również zmiany w składzie samego indeksu. Jak zauważono, indeks tworzyły 33 papiery

Ry s u n e k 1. Kształtowanie się wartości indeksu piłkarskiego w latach 2002-2013

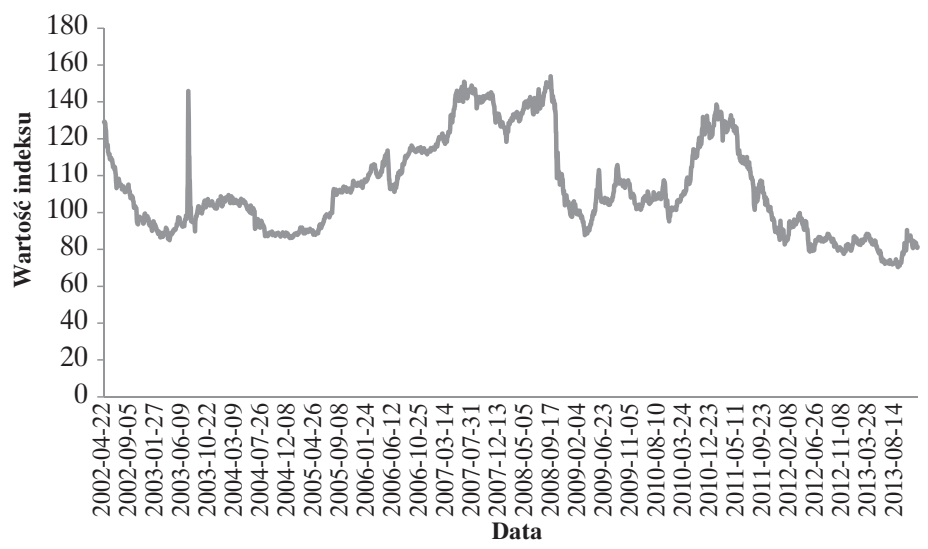

Źródło: opracowanie własne. 
wartościowe, a w obecnie jest ich 23. Co prawda, korzystnie dla stabilizacji samego indeksu, sytuacja przestała się zmieniać dynamicznie od 2009 r. W 2010 r. indeks tworzyły 24 spółki, z czego 4 pochodziły z Wielkiej Brytanii, natomiast w obecnym składzie są tylko dwie reprezentujące przeciętną ligę szkocką (jedna ze spółek jest w niższej klasie rozgrywkowej, do której trafiła ze względu na kłopoty finansowe). Po zestawieniu obecnego składu indeksu z rankingiem zaprezentowanym przez Delloitte'a okazuje się, że na 20 spółek w rankingu tylko 3 (15\%) jest jednocześnie komponentami indeksu. Podobna sytuacja dotyczy lig reprezentowanych w najlepszej dwudziestce. Jedynie 5 spółek reprezentuje najlepsze ligi europejskie, przy czym nie ma w indeksie reprezentantów takich lig, jak angielska czy hiszpańska.

Jednym z ważniejszych klubów piłkarskich, którego właścicielem jest spółka giełdowa, wśród składników indeksu piłkarskiego jest Borussia Dortmund. Spośród trzech spółek, które wystąpiły jednocześnie w opisywanym wyżej raporcie i wśród składników indeksu DJ Stoxx F, jako jedyna osiągnęła sukces sportowy zarówno na rynku krajowym, jak i zagranicznym. Stąd hipoteza, że jeżeli BVB w indeksie waży blisko $12 \%$, to nie bez znaczenia dla wartości indeksu będą jej wyniki sportowe.

31 października 2000 r. Borussia Dortmund zadebiutowała na rynku podstawowym Giełdy we Frankfurcie z ceną 11 euro za akcję. Była to pierwsza emisja papierów wartościowych klubu piłkarskiego w Niemczech (http:// www.bvb.de/Der-BVB/Chronik/2000). Celem władz spółki było nie tylko ratowanie finansów klubu, lecz także zapewnienie środków na rozwój w perspektywie długookresowej. W 2003 r. spółka skończyła rozbudowę stadionu, niestety rozpoczęło to szereg trudności finansowych. W 2005 r. spółka była bliska bankructwa spowodowanego ambitnymi planami i brakiem odpowiedniego montażu finansowego, co zakończyło się szybką zmianą zarządu. Od 2011 r. BVB odnotowuje pasmo sukcesów na arenie krajowej i międzynarodowej i dotyczy to również finansów klubu.

\section{Przegląd literatury i metodyka badań}

Prace nad występowaniem zjawiska sentymentu graczy giełdowych, odznaczającego się wpływem wyników klubów sportowych i innych informacji związanych z piłką nożną na zmiany cen papierów wartościowych, których emitentami są kluby piłkarskie, rozpoczęły się na początku XXI w. Przegląd ważniejszych dokonań w tym zakresie przedstawiono w tabeli 1. 
CZĘŚĆ II. MODELOWANIE ZJAWISK NA RYNKU KAPITAŁOWYM W WARUNKACH...

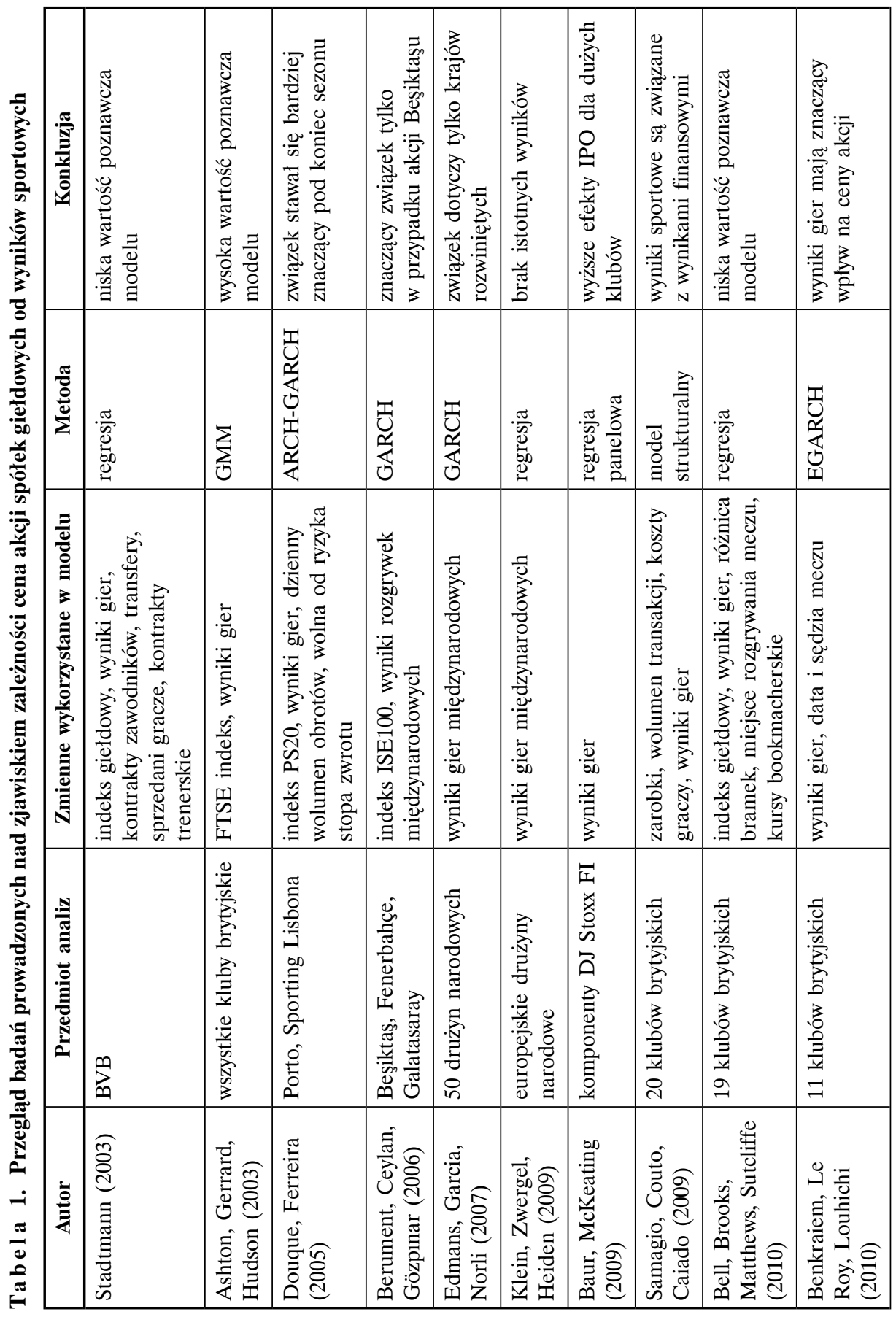




\begin{tabular}{|c|c|c|c|c|c|c|}
\hline 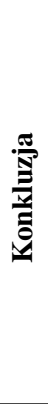 & 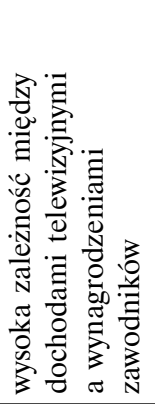 & 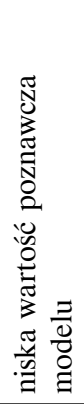 & 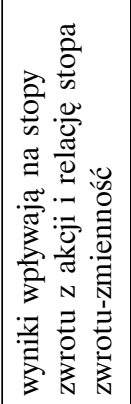 & 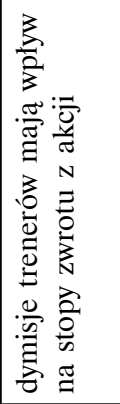 & 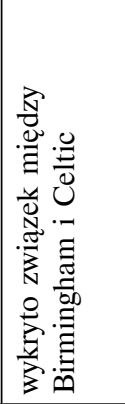 & 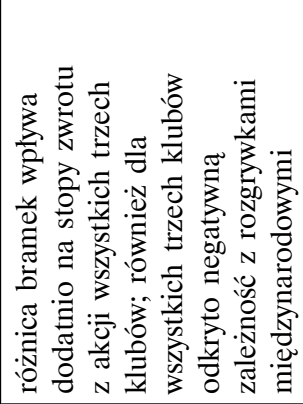 \\
\hline 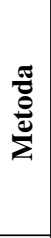 & 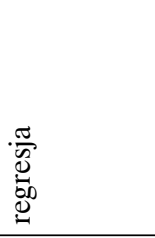 & 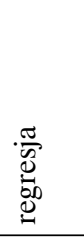 & 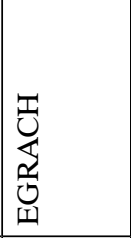 & 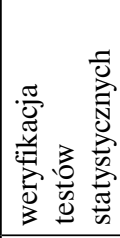 & 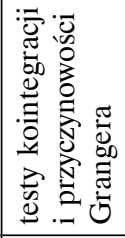 & 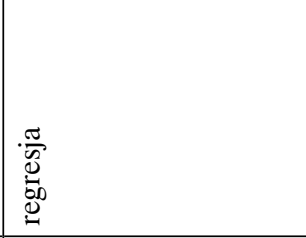 \\
\hline 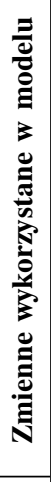 & 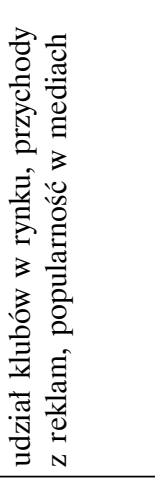 & 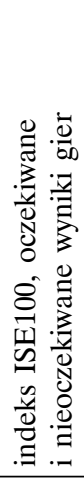 & 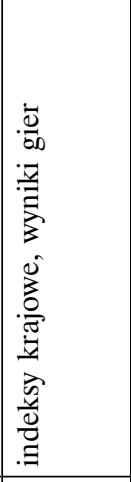 & 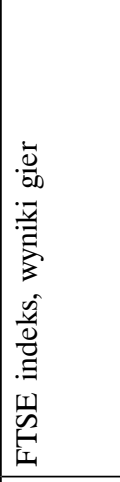 & 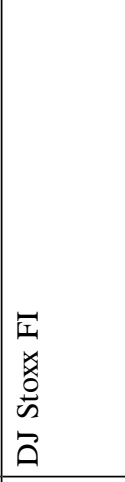 & 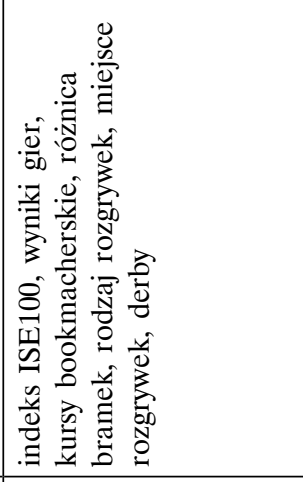 \\
\hline 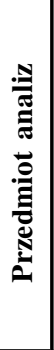 & 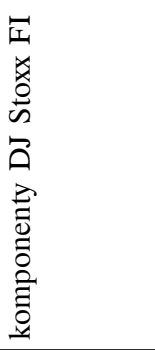 & 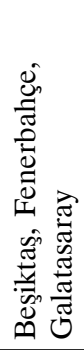 & 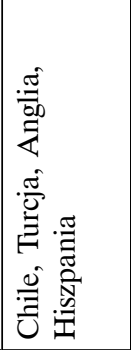 & 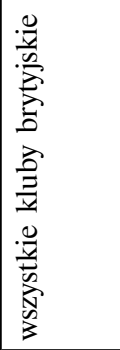 & 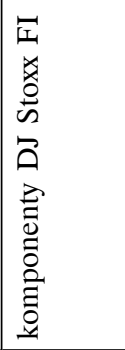 & 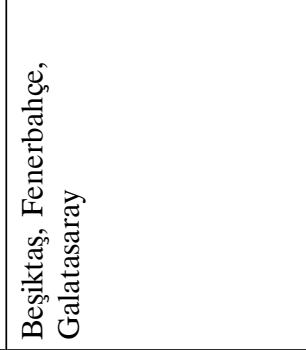 \\
\hline$\stackrel{\grave{E}}{\grave{E}}$ & 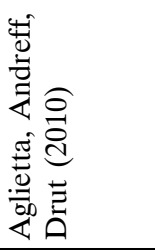 & 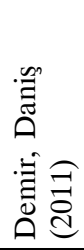 & 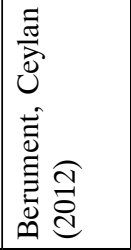 & 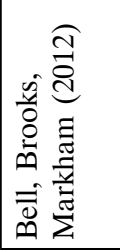 & 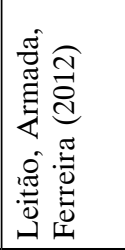 & 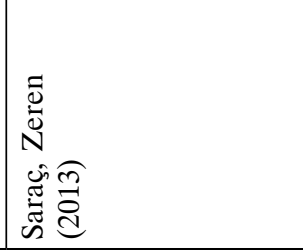 \\
\hline
\end{tabular}


Jak można zaobserwować, w niewielu przypadkach stosowanie metod ilościowych w procesie wykrywania związków między wynikami drużyn piłkarskich a kursami akcji spółek giełdowych nie przynosiło rezultatów. Często wykrywano związki o charakterze przyczynowym, które mogą być podstawą do podejmowania decyzji inwestycyjnych.

W prowadzonym badaniu zastosowano dwie metody badawcze oparte na:

- testach statystycznych,

- modelach autoregresyjnych.

W pierwszym podejściu zamierza się przeprowadzić weryfikację hipotezy statystycznej głoszącej, że stopy zwrotu przed wystąpieniem informacji i po wystąpieniu informacji są takie same, wobec hipotezy alternatywnej, że są różne (Edmans, Garcia i Norli 2007). Postawione hipotezy dotyczą takich problemów, jak:

- reakcja cen na informacje o zakupie/sprzedaży zawodników BVB;

- reakcja cen na informacje o wynikach meczów i Lidze Mistrzów (przegrana, wygrana).

W drugim podejściu zostanie wykorzystane modelowanie procesów autoregresyjnych (ARCH i GARCH) do określenia istotności następujących zdarzeń w kształtowaniu się stóp zwrotu z akcji Borussii Dortmund i wartości indeksu DJ Stoxx FI:

- wygrana/przegrana/remis w meczu ligowym;

- wygrana/przegrana/remis w Lidze Mistrzów;

- wygrana/przegrana/remis we wszystkich rozgrywkach (również w meczach towarzyskich);

- dzień rozgrywania meczów (dzień tygodnia).

$\mathrm{W}$ tej procedurze ustalono następujące zmienne zero-jedynkowe:

$\mathrm{L}_{\mathrm{BL}} \quad$ - przegrane w meczach Bundesligi;

$\mathrm{L}_{\mathrm{CL}} \quad$ - przegrane w meczach Ligi Mistrzów;

$\mathrm{L}_{\mathrm{ALL}}$ - przegrane w meczach wszystkich typów rozgrywek;

$\mathrm{W}_{\mathrm{BL}}$ - wygrane w meczach Bundesligi;

$\mathrm{W}_{\mathrm{CL}}$ - wygrane w meczach Ligi Mistrzów;

$\mathrm{W}_{\mathrm{ALL}}$ - wygrane w meczach wszystkich typów rozgrywek;

$\mathrm{D}_{\mathrm{BL}} \quad$ - remisy w meczach Bundesligi;

$\mathrm{D}_{\mathrm{CL}} \quad$ - remisy w meczach Ligi Mistrzów;

$\mathrm{D}_{\mathrm{ALL}}-$ remisy w meczach wszystkich typów rozgrywek;

M, T, W, TH, F - dni tygodnia: poniedziałek-piątek. 
Zakładana funkcja regresji, na podstawie której będą budowane modele autoregresyjne ma postać klasycznego modelu ekonometrycznego z wieloma zmiennymi objaśniającymi:

$$
y_{t}=\gamma_{0}+\sum_{k=1}^{n} \gamma_{k} X_{k t}+\varepsilon_{t} .
$$

Ogólna postać szacowanego modelu $\mathrm{ARCH}(\mathrm{q})$ przedstawia się następująco (Engle 1982):

$$
h_{t}=\alpha_{0}+\sum_{i=1}^{q} \alpha_{i} \varepsilon_{t-i}^{2}
$$

gdzie:

$$
\alpha_{0}>0, \quad 0 \leq \alpha_{i} \leq 1, \quad+\varepsilon_{t} \sim N\left(0, h_{t}\right) .
$$

Natomiast ogólna postać modelu GARCH jest następująca (Bollerslev 1986):

$$
h_{t}=\alpha_{0}+\sum_{i=1}^{q} \alpha_{i} \varepsilon_{t-i}^{2}+\sum_{j=1}^{p} \beta_{j} h_{t-j}
$$

Estymacja parametrów podanych modeli pozwoli odpowiedzieć na pytanie: czy czynniki o charakterze sportowym wpływające na stan emocjonalny inwestorów interesujących się futbolem mają istotny wpływ na kształtowanie się procesów cenowych na giełdzie papierów wartościowych. Szacowanie parametrów odbywa się metodą największej wiarygodności. W badaniu wykorzystano do tego celu program GRETL.

\section{Badanie empiryczne}

Na pierwszym etapie badania przeprowadzono weryfikację hipotez statystycznych o wpływie informacji nieekonomicznych na kształtowanie się stóp zwrotu z akcji Borussii Dortmund. Na podstawie informacji o liczebności poszczególnych podgrup stóp zwrotu stosowano testy na różnicę średnich w małej lub dużej próbie, a także obliczono wartość statystyki $p$, przy której można by było odrzucić hipotezę mówiącą o podobieństwie średnich. Dla weryfikacji hipotezy o wpływie wyniku meczu BVB na stopy zwrotu otrzymano wyniki zawarte w tabeli 2. 
Ta b e la 2. Wartości statystyk sprawdzających dla testów dla średnich stóp zwrotu uzyskanych przy zajściu określonych zdarzeń sportowych

\begin{tabular}{|l|c|c|}
\hline \multicolumn{1}{|c|}{ Pary zdarzeń } & $\begin{array}{c}\text { Wartość } \\
\text { statystyki }\end{array}$ & P-value \\
\hline Mecze wygrane v. mecze przegrane & $\mathbf{6 , 4 5}$ & 0,00000 \\
\hline Mecze wygrane v. mecze zremisowane & $\mathbf{5 , 1 3}$ & 0,00000 \\
\hline Mecze wygrane v. mecze przegrane i zremisowane & $\mathbf{7 , 3 8}$ & 0,00000 \\
\hline $\begin{array}{l}\text { Wygrane mecze w Bundeslidze v. przegrane i zremisowane mecze } \\
\text { w Bundeslidze }\end{array}$ & $\mathbf{6 , 6 1}$ & 0,00000 \\
\hline $\begin{array}{l}\text { Wygrane mecze w Bundeslidze v. wygrane mecze w rozgrywkach } \\
\text { europejskich }\end{array}$ & 0,04 & 0,48589 \\
\hline Dzień po meczu v. pozostałe dni sesyjne & $\mathbf{1 , 9 9}$ & 0,02283 \\
\hline
\end{tabular}

Źródło: obliczenia własne.

Na podstawie informacji zawartych w tabeli 2 można wnioskować, że stopy zwrotu uzyskiwane $\mathrm{z}$ akcji spółki BVB po meczach wygranych istotnie silnie różnią się od stóp zwrotu uzyskiwanych po meczach zremisowanych i przegranych tej drużyny. Nie ma znaczenia czy wygrane klubu dotyczą rozgrywek międzynarodowych, czy też rozgrywek krajowych - różnica między stopami zwrotu jest nieistotna statystycznie (hipotezę zerową w takim wypadku można odrzucić na poziomie istotności $\alpha=0,48589$ ). Naturalne w tym wypadku jest również twierdzenie, że na pierwszej sesji po rozegranych meczach wystąpią istotne statystycznie zmiany stóp zwrotu, o czym świadczy wartość ostatniej zawartej w tabeli statystyki. Ciekawe informacje zawierają również rozkłady stóp zwrotu dla analizowanych grup zdarzeń. Na podstawie stóp zwrotu $\mathrm{z}$ akcji BVB w latach 2010-2013 w dwóch grupach: po wygranych meczach oraz po meczach przegranych i zremisowanych obliczono podstawowe statystyki podsumowujące, które zaprezentowano w tabeli 3.

Na podstawie informacji zawartych w tabeli 3 można zauważyć, że różnica w dziennych stopach zwrotu, uzyskanych po meczach wygranych oraz przegranych i zremisowanych wynosi 3,2 punktu procentowego, czyli więcej niż odchylenia standardowe uzyskane w obu tych przypadkach. Należy dodać, że rozkłady dla analizowanych zmiennych różnią się również asymetrią - rozkład stóp zwrotu uzyskanych po wygranych meczach jest lekko asymetryczny prawostronnie, natomiast $\mathrm{w}$ drugim przypadku asymetria ta jest wyraźna lewostronna. Również wartości najmniejsze i największe uzyskane w grupach wskazują wyraźnie, że po wygranych meczach można się spodziewać zdecydowanie wyższych stóp zwrotu niż w przypadku pozostałych 
Ta b e la 3. Podstawowe statystyki opisowe dla stóp zwrotu z akcji BVB w latach 2010-2013

\begin{tabular}{|l|c|c|}
\hline \multicolumn{1}{|c|}{ Parametr } & Wygrane & Przegrane i remisy \\
\hline Średnia & $0,88 \%$ & $-2,32 \%$ \\
\hline Mediana & $0,76 \%$ & $-1,57 \%$ \\
\hline Wartość najczęstsza & $0,85 \%$ & $0,00 \%$ \\
\hline Odchylenie standardowe & $3,03 \%$ & $2,94 \%$ \\
\hline Spłaszczenie & 1,93 & 2,25 \\
\hline Asymetria & 0,40 & $-1,33$ \\
\hline Minimum & $-7,99 \%$ & $-13,51 \%$ \\
\hline Maksimum & $12,20 \%$ & $2,25 \%$ \\
\hline
\end{tabular}

Źródło: obliczenia własne.

spotkań. Można by zatem twierdzić, że wykryto występowanie efektów „wygranych i przegranych meczów”.

Aby jednak wykluczyć przypadek, należy zweryfikować hipotezę o występowaniu efektu poniedziałku czy też innego dnia tygodnia. Dlatego też postawiono hipotezy zerowe, że we wszystkich dniach tygodnia stopy zwrotu są jednakowe. $\mathrm{W}$ tym wypadku na poziomie istotności $\alpha=0,05$ nie było podstaw do odrzucenia hipotezy zerowej. To oznacza, że w analizowanych przypadkach nie występował efekt dnia tygodnia.

Kolejne postawione hipotezy dotyczyły następującego stwierdzenia: stopy zwrotu po ukazaniu się incydentalnych, ale ważnych informacji istotnych z punktu widzenia pozycji klubu piłkarskiego Borussia Dortmund mają wpływ na kształtowanie się stóp zwrotu z akcji tej spółki giełdowej. Ze względu na dostępność informacji medialnych do weryfikacji wybrano dane dzienne od początku 2013 r. Rok ten można jednak uważać za szczególny pod tym względem - od początku bowiem pojawiały się informacje o odejściu podstawowych zawodników (Roberta Lewandowskiego, Mario Goetze) oraz o możliwych zakupach zawodników na ich pozycje (Pierre Emerick Aubameyang, Henrikh Mhitaryan i inni). Szczególne znaczenie tych informacji polegało na spekulacjach o osłabieniu BVB i wzmocnieniu jej największego konkurenta w Niemczech - Bayernu Monachium. W tabeli 4 zawarto informacje o uzyskanych wartościach testów statystycznych dla wydarzeń: po publikacjach informacji niekorzystnych, korzystnych i bez takich wydarzeń.

Jak można zauważyć w tabeli 4 nie uzyskano satysfakcjonujących wyników weryfikacji statystycznej, jedynie w przypadku testów dla dwóch średnich w grupach: stóp zwrotu odnotowanych po pojawieniu się wiadomości, o któ- 
Ta b e l a 4. Wartości statystyk sprawdzających dla testów dla średnich stóp zwrotu uzyskanych przy zajściu określonych zdarzeń

\begin{tabular}{|l|c|c|}
\hline \multicolumn{1}{|c|}{ Pary zdarzeń } & $\begin{array}{c}\text { Wartość } \\
\text { statystyki }\end{array}$ & P-value \\
\hline Po wiadomościach o transferach v. bez takich wiadomości & 1,40 & 0,08121 \\
\hline $\begin{array}{l}\text { Po korzystnych dla klubu wiadomościach v. po niekorzystnych } \\
\text { wiadomościach }\end{array}$ & $-0,005$ & 0,49788 \\
\hline Po korzystnych dla klubu wiadomościach v. bez żadnych wiadomości & 0,86 & 0,19545 \\
\hline Po niekorzystnych dla klubu wiadomościach v. bez żadnych wiadomości & 0,87 & 0,19116 \\
\hline
\end{tabular}

Źródło: obliczenia własne.

rych mowa i stóp zwrotu z okresu, kiedy takie wiadomości się nie pojawiały zbliżono się do poziomu, dla którego można by odrzucić hipotezę zerową. W tym wypadku poziom ten nieznacznie musiałby przekroczyć 0,08 . Na fakt tak słabych wyników może wpływać incydentalność informacji - w tak małej skali trudno jest wnioskować. Jednak fakt uzyskania tak bliskich odrzucenia hipotezy zerowej wyników powoduje konieczność obserwacji tego zjawiska w przyszłości.

W drugiej części badania zdecydowano się na budowę modeli ekonometrycznych, które po pierwsze służyłyby pełniejszemu opisowi badanego zjawiska, jakim jest zmiana stóp zwrotu z akcji klubu piłkarskiego będącego spółką giełdową, a po drugie mogłyby być użytecznym narzędziem wspomagającym proces decyzyjny dla inwestorów giełdowych. Zostały skonstruowane dwa rodzaje modeli: pierwszy objaśniający stopy zwrotu z akcji BVB (tab. 5) i drugi objaśniający stopy zwrotu z indeksu giełdowego DJ Stoxx FI (tab. 6). W pierwszym przypadku potraktowano model ekonometryczny jako klasyczne narzędzie decyzyjne, natomiast $\mathrm{w}$ drugim przypadku - jako informację o zależności między indeksem giełdowym a czynnikami wpływającymi na stopy zwrotu $\mathrm{z}$ akcji, których udział w indeksie stanowi około $10 \%$.

Na podstawie oszacowanych modeli dla stopy zwrotu z akcji BVB wybrano, dzięki zastosowaniu kryterium logarytmu wiarygodności i kryterium Akaike'a, model, w którym stopę zwrotu objaśniają: zwycięstwa, remisy, przegrane oraz piątki. Uznano, że te zmienne w najbardziej istotny sposób wpływają na zmienną objaśnianą.

Na podstawie poczynionych oszacowań można zdecydowanie stwierdzić, że dla akcji Borussii Dortmund obserwuje się występowanie „efektu wyniku meczu", co oznacza, że po każdym wygranym meczu tego klubu można się spodziewać dodatnich stóp zwrotu na rynku akcji, a po każdym przegranym i zremisowanym ujemnych stóp zwrotu. Dodatkowo odkrytym faktem jest, 


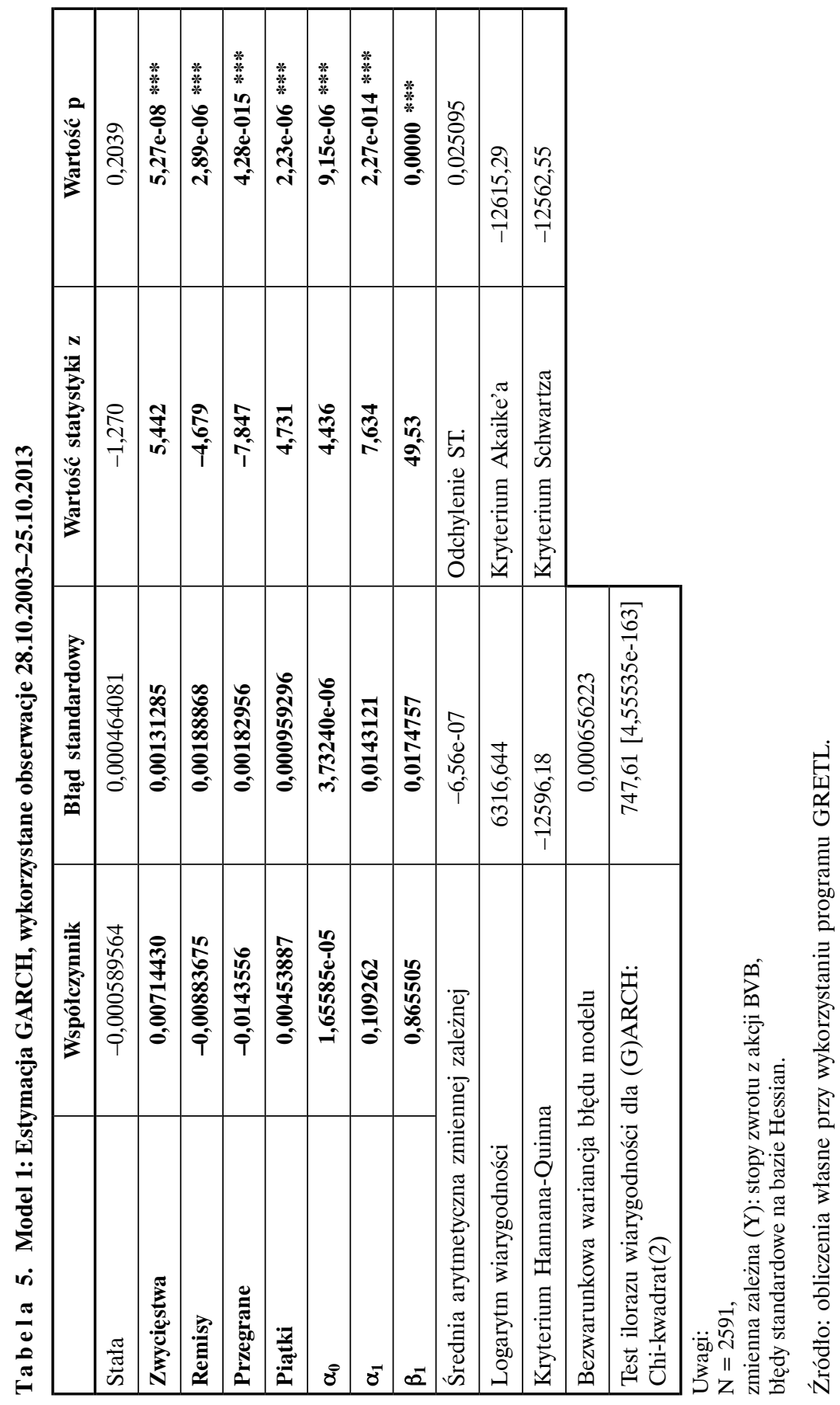




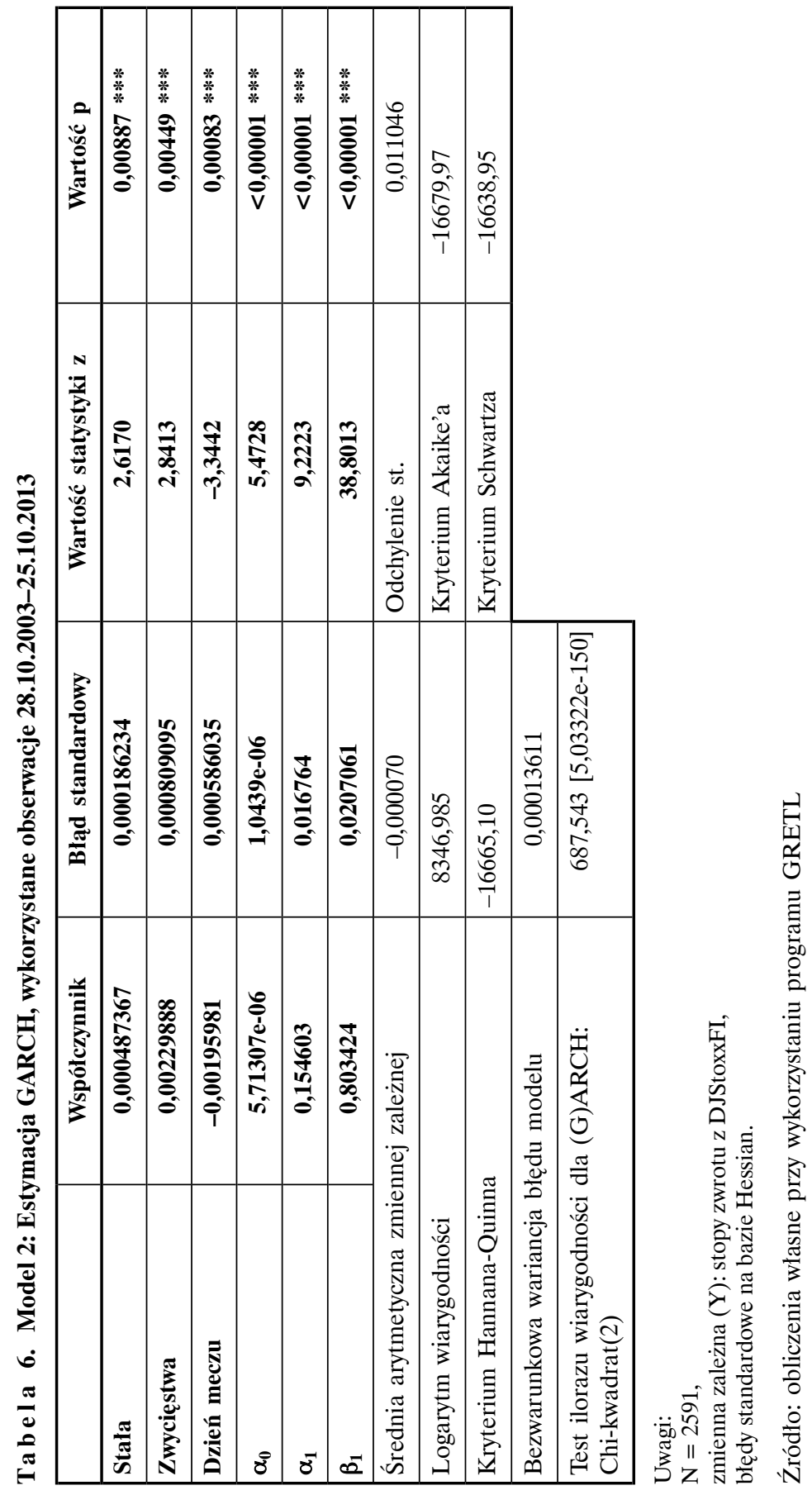


że jak wskazuje model, w każdy piątek można się spodziewać dodatnich stóp zwrotu.

Na podstawie podanych powyżej szacunków modelu $\operatorname{GARCH}(1,1)$ dla indeksu piłkarskiego DJ można wnioskować, że istnieje zależność między dniami rozgrywania meczów przez klub piłkarski Borussia Dortmund a stopami zwrotu $\mathrm{z}$ indeksu giełdowego, a także między sygnałami o wygranych meczach przez ten klub a analizowanymi stopami zwrotu. Z tym, że o ile wygrane skutkują wzrostami stóp zwrotu, o tyle dzień rozgrywania meczu skutkuje ich spadkami wartości. Niemniej jednak, jak można się było spodziewać, indeks ten wykazuje występowanie efektu „wygranych meczów”.

\section{Wnioski końcowe}

W niniejszym artykule została przeprowadzona analiza oddziaływania czynników o charakterze nieekonomicznym, a dokładniej informacji o wydarzeniach związanych z działalnością klubu sportowego BVB na kurs akcji i stopy zwrotu spółki giełdowej, będącej właścicielem tego klubu oraz indeksu giełdowego klubów piłkarskich Dow Jones Stoxx Football Index (DJ Stoxx FI). W badaniu wykorzystano testy statystyczne sprawdzające istotność różnic w zmianach cen przed i po zajściu zdarzenia, a także modele ekonometryczne typu GARCH $(1,1)$.

W trakcie badań udało się udowodnić, że:

1) zdarzenia sportowe, a w szczególności wyniki spotkań piłkarskich mają wpływ na zmiany stóp zwrotu $\mathrm{z}$ akcji BVB;

2) zmiany stóp zwrotu $z$ indeksu giełdowego DJ Stoxx FI są wrażliwe na zdarzenia sportowe związane z klubem piłkarskim BVB.

Można zatem stwierdzić, że występuje efekt działań emocjonalnych inwestorów giełdowych, który powodowanych jest czynnikami zewnętrznymi, takimi jak: wynik spotkania piłkarskiego czy dzień rozgrywania meczu. Takie efekty można nazwać efektami „wygranych i przegranych meczów”.

\section{Bibliografia}

Antonowicz, D., Szlendak, T. i Kossakowski, R. (2012). Piłkarz jako marka i preferencyjny kibic jako aborygen. O wybranych społecznych konsekwencjach komercjalizacji sportu, Kultura i Społeczeństwo, Sport w kulturze, 3, Warszawa.

Bollerslev, T. (1986). Generalized autoregressive conditional heteroskedasticity, Journal of Econometrics, 31. 
Deloitte, (2013). Captains of industry. Football Money League. Sport Business Group, January.

Duque, J. i Ferreira, N.A.A. (2005). Explaining Share Price Performance of Football Clubs Listed on The Euronext Lisbon. Instituto Superior de Economia e Gestao.

Edmans, A., Garcia, D. i Norli, O. (2007). Sports Sentiment and Stock Returns, The Journal of Finance, LXII, 4.

Engle, R. (1982). Autoregressive conditional heteroskedasticity with estimates of the variance of UK inflation, Econometrica, 50.

http://www.bvb.de/Der-BVB/Chronik/2000 (20.12.20013).

Leitão, J., da Rocha Amanda, M. i Ferreira, J. (2012). Corruption and Co-Movements in European Listed Sport Companies: Did Calciocaos really matter?, MPRA Paper No. 42474. Germany: University Library of Munich.

Majewski, S. (2012), Wpływ czynników behawioralnych na rynkową wycenę akcji. Ujęcie ilościowe, Rozprawy i Studia, t. 843. Szczecin: Wydawnictwo Naukowe Uniwersytetu Szczecińskiego.

Prabucki, B. (2012). Gry sportowe jako element wzmacniający współczesne tożsamości etniczne. Analiza na przykładzie Basków, Homo Ludens, 1(4).

Saraç, M. i Zeren, F. (2013). The Effect of Soccer Performance on Stock Return: Empirical Evidence From "The Big Three Clubs" of Turkish Soccer League, Journal of Applied Finance \& Banking, 3(5).

Stadtmann, G. (2003). An Empirical Examination of the News Model: The Case of Borussia Dortmund GmbH \& Co. KGaA, Zeitschrift f"ur Betriebswirtschaft, 74(2). 


\title{
Rozdział XI
}

\author{
PIOTR JAWORSKI*, HUBERT WIŚNIEWSKI**
}

\section{Rynkowe wykorzystanie kointegracji \\ - osiąganie absolutnych stóp zwrotu z kontraktów futures notowanych na GPW w Warszawie}

\begin{abstract}
Streszczenie
Celem artykułu jest analiza długoterminowych zależności pomiędzy cenami kontraktów terminowych notowanych na Giełdzie Papierów Wartościowych w Warszawie. Po dokonaniu przeglądu literatury światowej na temat funkcjonowania wspomnianego zjawiska, poddano weryfikacji występowanie pomiędzy nimi kointegracji. W tym celu wykorzystano metodę Johansena. Na jej podstawie stwierdzono występowanie kointegracji pomiędzy analizowanymi cenami derywatów. Następnie dokonano konstrukcji opartych na niej portfeli inwestycyjnych realizujących strategie typu long-short i jednocześnie będących neutralnymi w stosunku do rynku. Uzyskane wyniki wskazują na istnienie wzajemnych długoterminowych związków pomiędzy cenami rozpatrywanych kontraktów. Wyniki zastosowanej strategii inwestycyjnej okazały się niezwykle interesujące i zgodne z oczekiwaniami autorów.
\end{abstract}

Słowa kluczowe: kontrakty terminowe, kointegracja, absolutna stopa zwrotu.

\section{Summary}

The main goal of this article is analysis the long-term relationship between futures prices quoted on the Warsaw Stock Exchange. After making research of the world literature on this topic, the presence of cointegration between them has been verified. For this purpose was used the Johansen metod. On the basis of the occurrence of cointegration between the analyzed prices of derivatives investment portfolios of pursuing policies of a long-short, while being neutral in

* Mgr Piotr Jaworski - doktorant, Wydział Zarządzania, Uniwersytet Warszawski; e-mail: pjaworski@mail.wz.uw.edu.pl.

** Mgr Hubert Wiśniewski - doktorant, Wydział Nauk Ekonomicznych, Uniwersytet Warszawski; e-mail: hubertwis82@wp.pl. 
relation to the market were constructed. The results indicate the existence of long-term mutual relationships between the prices of the chosen contracts. The results of the investment strategy are extremely interesting and in line with the authors expectations.

Keywords: futures, cointegration, absolute return.

\section{Wstęp}

Zapoczątkowany w 2008 r. światowy kryzys na rynkach finansowych zmienił w znacznym stopniu obraz, do którego byli przyzwyczajeni inwestorzy. Ceny wielu aktywów spadły, zwiększyła się ich zmienność oraz przekształciły występujące między nimi korelacje. To spowodowało, że wiele działających na rynku funduszy inwestycyjnych poniosło znaczne straty na zarządzanych przez siebie portfelach, co pchnęło je do poszukiwania alternatywnych metod pomnażania katitału, najlepiej w sposób niezależny od bieżącej sytuacji rynkowej. Rozwiązaniem bolączek inwestorów miały okazać się fundusze o charakterze absolutnej stopy zwrotu (absolute return), które mają za zadanie wypracowanie stabilnego zysku, pozostając neutralne w stosunku do rynków finansowych, na których operują.

Wiele tego rodzaju funduszy stosuje strategie inwestycyjne typu longshort, co oznacza, że część zarządzanego portfela inwestycyjnego stanowią długie pozycje w określonym rodzaju aktywach, a część pozycje krótkie, dobrane tak, aby wartość portfela wzrastała niezależnie od bieżącej sytuacji rynkowej. Aby zbudować taki portfel inwestycyjny, należy określić wzajemne, stałe relacje między znajdującymi się w nim instrumentami finansowymi. Tradycyjna teoria analizy portfelowej zakłada model oparty na korelacji, który niestety nie może być obecnie stosowany ze względu na brak jej niezmienności w czasie. By poradzić sobie z tym problemem, można zastosować ilościowe techniki w finansach oparte na ekonometrii i statystyce, dzięki którym zostanie wyznaczona względnie stała w czasie relacja między zachowaniem się cen instrumentów finansowych. Tehniką tą jest kointegracja, która bazuje na analizie szeregów czasowych cen danego instrumentu, a nie jego stóp zwrotu. Dzięki jej zastosowaniu nie traci się cennych informacji o występowaniu trendu, które są pomijane w analizie ich pierwszych różnic, czyli korelacji stóp zwrotu.

Celem niniejszego artykułu jest wyznaczenie stałej relacji między zachowaniem się cen kontraktów terminowych notowanych na Giełdzie Papierów Wartościowych w Warszawie, określenie stopnia ich oddziaływania oraz konstrukcja za ich pomocą portfela inwestycyjnewgo dającego dodatnie stopy 
zwrotu niezależnie od warunków rynkowych, który mógłby być wykorzystywany przez fundusze absolutnej stopy zwrotu. Autorzy próbują odpowiedzieć na pytanie czy na GPW można generować dodatkową alfę przez wykorzystanie technik używanych na świecie przez fundusze hedgingowe. Strategia dla funduszy została wykonana poprzez zastosowanie modelowania ekonometrycznego opartego na tygodniowych danych dotyczących cen kontraktów futures notowanych na GPW.

\section{Kointegracja a korelacja}

Najogólniej mówiąc, korelacja jest związkiem pomiędzy dwiema zmiennymi losowymi. Nie dowodzi więc ona żadnego związku przyczynowo-skutkowego. Natomiast kointegracja oznacza długookresową zależność procesów finansowych, którą interpretuje się jako ścieżkę równowagi niezależną od czasu. Najbardziej znaną definicją kointegracji jest definicja kointegracji dwóch zmiennych zaproponowana przez R.F. Engela i C.W.J. Grangera (1987), zgodnie z którą szeregi czasowe $X_{t}$ i $Y_{t}$ są skointegrowane rzędu $d, b$, gdzie $d \geq b \geq 0$, co zapisujemy jako $X_{t}, Y_{t} \sim C I(d, b)$, jeśli:

1) oba szeregi są zintegrowane rzędu $d\left(X_{t} Y_{t} \sim I(d)\right)$,

2 ) istnieje liniowa kombinacja tych zmiennych, tzn. $\beta_{1} X_{t}+\beta_{2} Y_{t}$, która jest integrowana rzędu $d-b$.

Natomiast wektor $\left[\beta_{1}, \beta_{2}\right]$ nazywany jest wektorem kointegracyjnym. Powyższą definicję można uogólnić na przypadek $n$ zmiennych. Wtedy to, jeśli $Z_{t}$ oznacza $n \times 1$ wektor zmiennych $Z_{1 t}, Z_{2 t}, \ldots, Z_{n t}$ oraz:

1) każda $z$ nich jest $I(d)$,

2) istnieje $n \times 1$ wektor taki, że $Z_{t}^{\prime} \beta \sim I(d-b)$,

to $Z_{t}^{\prime} \beta \sim C I(d, b)$. Empirycznie najbardziej interesujący jest przypadek, gdy szereg transformowany $\mathrm{z}$ użyciem wektora kointegracyjnego staje się stacjonarny, tzn. gdy: $d=b$, a współczynniki kointegracji (czyli tworzące wektor kointegracyjny) mogą być utożsamiane z długookresowymi związkami pomiędzy tymi zmiennymi.

Dlatego też wysoka korelacja może istnieć zarówno, gdy istnieje kointegracja, jak i gdy kointegracji nie ma, przenosząc to chociażby do analizy cen walorów giełdowych. Korelacja odnosi się tylko do krótkoterminowych zależności między stopami zwrotu. Nie można zaś za jej pomocą uchwycić długoterminowych związków między cenami walorów. Do tego niezbędna jest kointegracja procesów opisujących ruch tych cen. Dlatego też klasyczne 
strategie hedge funds, bazujące tylko na korelacjach, nie gwarantują zysków w długim okresie. Jednak, pomimo ciągłego rozwoju finansów ilościowych i empirycznych, przy analizie finansowych szeregów czasowych wielu badaczy opiera się głównie na korelacji badanych zmiennych. Podejście to należy jednak rozszerzyć w celu prawidłowej analizy badanego zjawiska. Wynika to chociażby z faktu, że korelacje można stosować do szeregów stacjonarnych tzw. $I(0)$, tzn. opisywanych przez proces stochastyczny, którego łączny rozkład jest stały. Oznacza to jednak niezmienność w czasie wszystkich momentów zwykłych i centralnych. Należy również dodać, że większość zmiennych finansowych opisywana jest przez szeregi niestacjonarne, zazwyczaj $I(1)$, czyli dopiero pierwsze różnice tej zmiennej są stacjonarne. Dlatego stosowanie korelacji dla takich zmiennych jest metodologicznie niepoprawne. Co więcej większość tradycyjnych modeli regresji stosowanych do tego typu danych prowadzi do tzw. regresji pozornych. Regresja taka zazwyczaj charakteryzuje się bardzo dobrymi właściwościami statystycznymi, tzn. istotnymi parametrami strukturalnymi i wysoką wartością współczynnika dopasowania $R^{2}$. Jednak wnioskowanie w oparciu o taką regresję jest nieuzasadnione. Wyjściem z sytuacji wydaje się sprowadzanie zmiennych $I(1)$, przez różnicowanie do zmiennych stacjonarnych. Jednak modelowanie na pierwszych różnicach pozwala uzyskać tylko tzw. relacje krótkookresowe wpływu zmiennych objaśnianych na zmienną objaśniającą. Istnieje jednak rozwiązanie dla tej teoretycznie patowej sytuacji. Mianowicie równania dla przyrostów zmiennych można w pewnych przypadkach uzupełnić o tzw. składnik korekty błędem, który wyraża długookresową relację pomiędzy niestacjonarnymi zmiennymi. Modele uzupełnione o taki składnik nazywane są modelami korekty błędem (ECM). Podstawową kwestią dla sformułowania odpowiedniego modelu dla zmiennych niestacjonarnych jest zatem stwierdzenie czy istnieje dla nich relacja długookresowa. Jeśli tak, to mówimy, że zmienne są skointegrowane. Dlatego też badanie kointegracji zmiennych ma fundamentalne znaczenie do przeprowadzania dalszych analiz zależności między zmiennymi i wyciągania na ich podstawie poprawnych wniosków. Do najbardziej popularnych metod badania kointegracji zalicza się metodę Engle’a i Grangera, która jednak nie jest pozbawiona licznych wad. Dlatego w tej pracy do badania kointegracji analizowanych zmiennych zostanie wykorzystana bardziej wyrafinowana metoda Johansena, bazująca na modelach wektorowo-autoregresyjnych. Zostanie ona przedstawiona nieco szerzej w części czwartej niniejszego artykułu 


\section{Dlaczego warto używać kointegracji w zarządzaniu portfelem}

Stwierdzenie występowania kointegracji dla indeksu i wybranych instrumentów oznacza wyznaczenie stałego spreadu pomiędzy indeksem a naśladującym go portfelem. W takim przypadku w długim terminie stopy zwrotu $\mathrm{z}$ portfela replikującego będą równe tym z naśladowanego indeksu. Dodatkowo ze względu na wyznaczanie zależności na szeregach czasowych obejmujących długi termin otrzymane za pomocą tej metody udziały poszczególnych aktywów w portfelu są mało wrażliwe na krótkoterminowe zmiany cen, jak na przykład bańki spekulacyjne. W krótkim terminie możliwe są odchylenia od wyznaczonej równowagi, spowodowane zmianami krótkookresowych korelacji pomiędzy portfelem replikującym a indeksem, jednak takie sytuacje należy traktować jako dodatkowe źródło alfy w portfelu, możliwe do osiągnięcia poprzez zastosowanie arbitrażu. Gdy w analizowanym szeregu czasowym pojawia się choćby niewielki trend liniowy, modelowanie go za pomocą korelacji stóp zwrotu, czyli pierwszych różnic logarytmów naturalnych jego cen, prowadzi do wyeliminowanie tego trendu i co za tym idzie do utracenia części cennych informacji na temat zachowania się cen. Dlatego też stosowanie kointegracji jest bardziej właściwe do analizy zachowania się instrumentów finansowych.

Na podstawie zależności kointegracyjnych można konstruować trzy rodzaje strategii inwestycyjnych (Alexander i Dimitriu 2002). Pierwszą z nich jest naśladowanie benchmarku przez portfel inwestycyjny. Strategia ta ma za zadanie replikowanie danego indeksu w zakresie stóp zwtotu i jego zmienności. Mając wyznaczoną prostą zależność śledzącą indeks, można zastosować naturalne rozszerzenie jej potencjału, czyli naśladowanie „sztucznych” indeksów zbudowanych poprzez dodanie do wartości wyjściowych pewnej stopy zwrotu przyrastającej w czasie tak, aby przywyższała lub obniżała wartości indeksu o określoną ilość punktów procentowych. Indeksy te nazywane są indeskami plus lub minus. Tak skonstruowany portfel może być wykorzystany do zbudowania strategii long-short, zajmując odpowiednie pozycje w nim i bazowym indeksie lub w indeksach plus oraz minus. Trzeci rodzaj strategii inwestycyjnych polega na zastosowaniu samego portfela replikującego indeks plus, żeby posiadać portfel dający stopy zwrotu lepsze niż jego benchmark.

Dotychczasowe badania kointegracji na rynkach finansowych zostały zapoczątkowane przez A. Lucasa (1997) i C.O. Alexander (1999). Stwierdzono, że jej główne charakterystyki, takie jak stacjonarny błąd standardowy 
regresji oraz stabilność parametrów, pozwalają na projektowanie zróżnicowanych technik tradingowych, począwszy od naśladowania indeksu do strategii typu long-short będących neutralnymi względem rynku. Alexander i Dimitriu (2002), testując w latach 1995-2001 strategie oparte na kointegracji z indeksem DJIA, uzyskały najlepszy wynik ze stopą zwrotu na poziomie $10 \%$ w skali roku, przy odchyleniu standardowym $2 \%$ i niską korelacją z indeksem. Również inne badania amerykańskiego rynku giełdowego (Alexander, Giblin i Weddington 2002) wskazują na występowanie na nim kointegracji i możliwości tworzenia strategii neutralnych względem rynku. Kointegracja była też badana dla kontraktów ternimowym na towary rolne (Arendalski i Postek 2012). Autorzy wykazali możliwości realizacji abnormalnych zysków ze strategii na niej opartej, przy jednoczesnej niskiej korealcji z rynkiem akcji.

\section{Dane i badanie ich kointegracji}

W badaniu wykorzystano dane tygodniowe dla kontraktów futures dla pięciu walorów: indeksu WIG 20 (lnFW20) oraz akcji spółek: PKN Orlen, KGHM Polska Miedź, PEKAO SA, PKO BP. Z pojawieniem się na rynku tych ostatnich wiąże się początek analizowanych szeregów, tj. 15 lipca 2005 r., koniec zaś to 13 października 2013 r. Zgodnie z literaturą dotyczącą tego zagadnienia, analizie zostały poddane logarytmy cen wymienionych powyżej kontraktów futures. Rysunek 1 obrazuje wahania rozpatrywanych wielkości w całym badanym okresie. Na jego podstawie można dostrzec relację długookresową między nimi.

W celu sprawdzenia kointegracji rozpatrywanych zmiennych zastosowano wspomnianą metodę Johansena. Metoda Johansena jest dużo efektywniejsza od procedury Engle'a-Grangera, pozwala ona bowiem otrzymać wszystkie wektory kointegrujące jednocześnie. Należy zwrócić uwagę, że metoda Johansena wymaga tego samego stopnia integracji zmiennych. Zakłada się, że wynikiem tego etapu jest stwierdzenie czy zmienne są zintegrowane rzędu pierwszego. Do tego zadania wykorzystano dwa powszechnie stosowane w literaturze testy: Dickey-Fuller i Phillips-Perron.

Tabela 1 przedstawia wyniki, które dla wszystkich rozpatrywanych szeregów są zgodne i jednoznaczne. Mianowicie każda z analizowanych zmiennych nie jest stacjonarna, świadczą o tym niskie wartości statystyk dla obydwu testów. Dlatego też nie można odrzucić hipotezy zerowej o obecności pierwiastka jednostkowego (niestacjonarności badanego szeregu). Natomiast 
Ry s u n e 1. Wahania logarytmu cen kontraktów futures na indeks WIG 20 oraz akcje PKN Orlen, KGHM, PEKAO SA, PKO BP w okresie

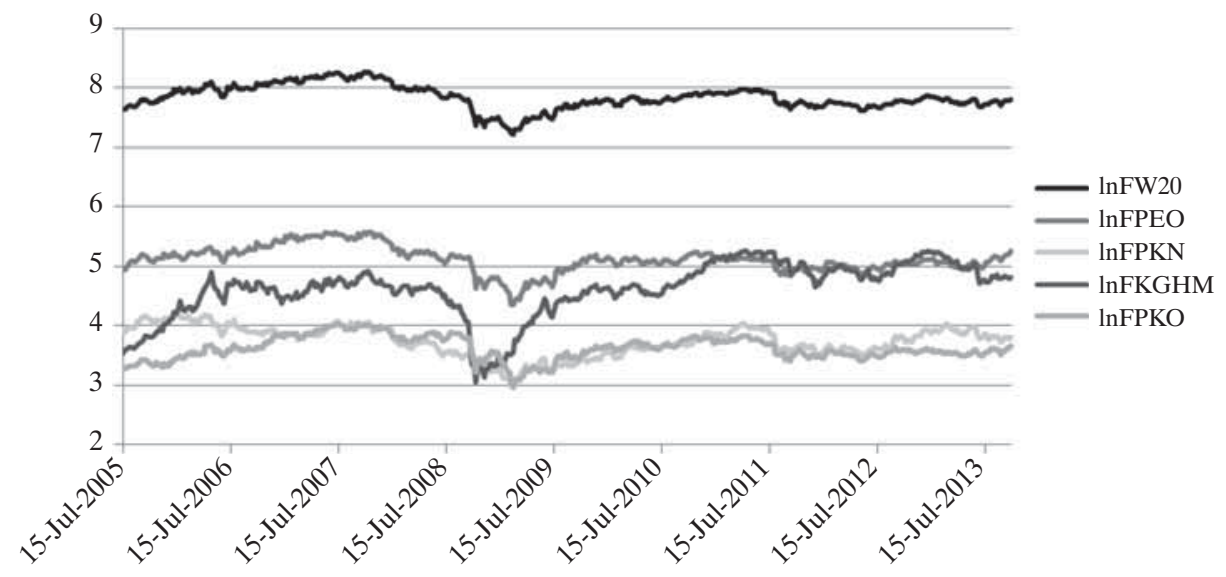

Źródło: opracowanie własne.

w przypadku pierwszych różnic (oznaczone $\Delta \mathrm{w}$ tab. 1), dla każdej z rozpatrywanych zmiennych wartości statystyk testowych są większe od odpowiednich wartości krytycznych dla obydwu testów. Wynik taki daje podstawy do odrzucenia hipotez zerowych i uznania, że badane pierwsze różnice są stacjonarne. Wynika więc $z$ tego jasno, że jeżeli zmienne są niestacjonarne, a ich pierwsze różnice stacjonarne, to dysponujemy zmiennymi zintegrowanymi rzędu pierwszego tzw. $I(1)$.

Jak już wspomniano, metoda Johansena opiera się na modelach wektorowo-autoregresyjnych. W tym celu należy dokonać właściwej specyfikacji tego modelu, co wiąże się między innymi z doborem właściwej liczby opóźnień zmiennych w modelu.

Do ustalenia liczby opóźnień w modelu wykorzystano powszechnie stosowane kryteria informacyjne, takie jak: AIC (Akaike's information criterion), SBIC (Schwartz Bayesian information criterion), HQIC (Hannan and Quinn information criterion). W tym przypadku ich wyniki były jednoznaczne i wskazały użycie modelu z pierwszymi opóźnieniami.

Kolejnym krokiem w całej procedurze Johansena jest testowanie rzędu macierzy współczynników, która została zdefiniowana w modelu korekty błędem. Rząd tej macierzy należy utożsamiać jako liczbę liniowo niezależnych wektorów kointegracyjnych. W przypadku, gdy rząd jest równy zeru, 
Ta be la 1. Wartości statystyki $Z(t)$ testów: Dickey-Fuller i Phillips-Perron

\begin{tabular}{|l|c|c|}
\hline \multicolumn{1}{|c|}{ Zmienne } & Dickey-Fuller & Phillips-Perron \\
\hline $\ln F W 20$ & $-1,946$ & $-1,969$ \\
\hline$\Delta \ln F W 20$ & $-19,619^{*}$ & $-19,590^{*}$ \\
\hline $\ln \mathrm{FPEO}$ & $-2,126$ & $-2,121$ \\
\hline$\Delta \ln F P E O$ & $-20,315^{*}$ & $-20,314^{*}$ \\
\hline $\ln \mathrm{FPKN}$ & $-1,986$ & $-1,871$ \\
\hline$\Delta \ln F P K N$ & $-21,578^{*}$ & $-21,653^{*}$ \\
\hline $\ln \mathrm{FKGHM}$ & $-2,429$ & $-2,494$ \\
\hline$\triangle \ln F K G H M$ & $-19,936^{*}$ & $-19,991^{*}$ \\
\hline $\ln \mathrm{FPKO}$ & $-2,492$ & $-2,633$ \\
\hline$\triangle \ln F P K O$ & $-19,394^{*}$ & $-19,383^{*}$ \\
\hline
\end{tabular}

Uwaga: wartości krytyczne: $-3,446$ i $-2,873$ odpowiednio dla poziomu istotności 1 i $5 \%$; dla rozpatry-

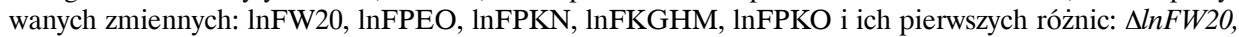

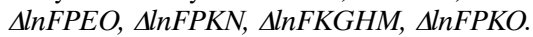

Źródło: opracowanie własne.

rozpatrywane zmienne nie są skointegrowane. Jak wynika z rysunku 2 między analizowanymi zmiennymi istnieje jeden wektor koinegracyjny. Wektor ten nie będzie prezentowany, gdyż nie jest to celem tej pracy. Jednak jego istnienie jest fundamentalne do prowadzenia dalszych badań będących przedmiotem tego artykułu.

Ponieważ stwierdzono kointegrację pomiędzy analizowanymi zmiennymi, w kolejnym kroku badania zbudowano porfel naśladujący zachowanie

\section{Ry s u n e 2. Wynik testu kointegracji}

\begin{tabular}{|c|c|c|c|c|c|c|}
\hline \multicolumn{7}{|c|}{ Johansen tests for cointegration } \\
\hline Trend: c & onstant & & & & Number of obs $=$ & 430 \\
\hline Sample: & $2-431$ & & & & Lags $=$ & 1 \\
\hline & & & & & $5 \%$ & \\
\hline maximum & & & & trace & critical & \\
\hline rank & parms & LL & eigenvalue & statistic & value & \\
\hline 0 & 5 & 4490.187 & . & 68.8094 & 68.52 & \\
\hline 1 & 14 & 4503.4756 & 0.05994 & $42.2323 *$ & 47.21 & \\
\hline 2 & 21 & 4512.7775 & 0.04234 & 23.6284 & 29.68 & \\
\hline 3 & 26 & 4519.9775 & 0.03293 & 9.2284 & 15.41 & \\
\hline 4 & 29 & 4523.2664 & 0.01518 & 2.6506 & 3.76 & \\
\hline 5 & 30 & 4524.5917 & 0.00615 & & & \\
\hline
\end{tabular}

Źródło: opracowanie własne. 
cen kontraktów terminowych na indeks WIG20 powiększony o pięć punktów procentowych w skali roku. Zastosowano pięcioletnie okresy testowe, na których wyznaczano współczynniki wektora kointegracji, korzystając z kroczącej regresji liniowej, gdzie każdy kolejny krok wynosił cztery tygodnie. W obliczeniach nie uwzględniono kosztów transakcyjnych występujących na rynku, ponieważ dla kontraktów terminowych znajdują się one na bardzo niskim poziomie i nie powinny w znaczny sposób wpływać na wyniki badania. Estymacje były przepreowadzane na następującym modelu:

$$
\ln \text { FW20plus }=\alpha+\beta_{1} \ln f p e o+\beta_{2} \ln f p k n+\beta_{3} \ln f k g h+\beta_{4} \ln f p k o+\varepsilon,
$$

gdzie:

ln FW20plus - logarytm naturalny cen kontraktów terminowych na WIG20 powiększony o pięć punktów procentowych w skali roku,

$\ln f p e o, \ln f p k n, \ln f k g h, \ln f p k o$ - logarytmy naturalne cen kontraktów terminowych na Pekao, PKN Orlen, KGHM oraz PKO BP.

Dla każdej z tak przeprowadzonych estymacji brano pod uwagę jej współczynniki $\beta$, normalizowano do jedności i w ten sposób wyznaczano wagi poszczególnych kontraktów w portfelu replikującym. W kolejnym kroku testowano zachowanie się strategii $\mathrm{w}$ okresie poestymacyjnym czterech tygodni dla każdego z okresów testowych. Skumulowane stopy zwrotu z tak zaprojektowanej strategii prezentuje zmienna fplus na rysunku 3. Rysunek przedstawia również skumulowane stopy zwrotu dla samych kontraktów terminowych na WIG20 ( $f w$ ) oraz strategii inwestycyjnej polegającej na zajęciu długiej pozycji w porfelu naśladującym zachowanie cen kontraktów terminowych na indeks WIG20 powiększony o pięć punktów procentowych oraz krótkiej pozycji w kontraktach terminowych na indeks WIG20 (plus-fw). Tak zaprojektowana strategia powinna być neutralna wobec rynku oraz przynosić stopę zwrotu na pozione 5\% w skali roku.

Zgodnie z przyjętymi założeniami skumulowana stopa zwrotu z portfela indeks plus znajduje się przez cały okres testowy powyżej stopy zwtotu ze swojego benchmarku, czyli kontraktów terminowych na WIG20. Można również zauważyć, że zgodnie z celem konstrukcji takiego portfela replikacyjnego różnica między nimi przyrasta w czasie. Po złożeniu tych portfeli w strategię typu market neutral otrzymano portfel, którego skumulowana stopa zwrotu jest dodatnia we wszystkich poza jednym z testowanych okresów, co należy uznać za zdecydowanie pozytywne i oczekiwane działanie tej strategii. Realizuje ona zwrot na poziomie $4,56 \%$ w skali roku, co również jest bardzo 
Ry s u n e k 3. Skumulowane stopy zwrotu $z$ analizowanych strategii inwestycyjnych

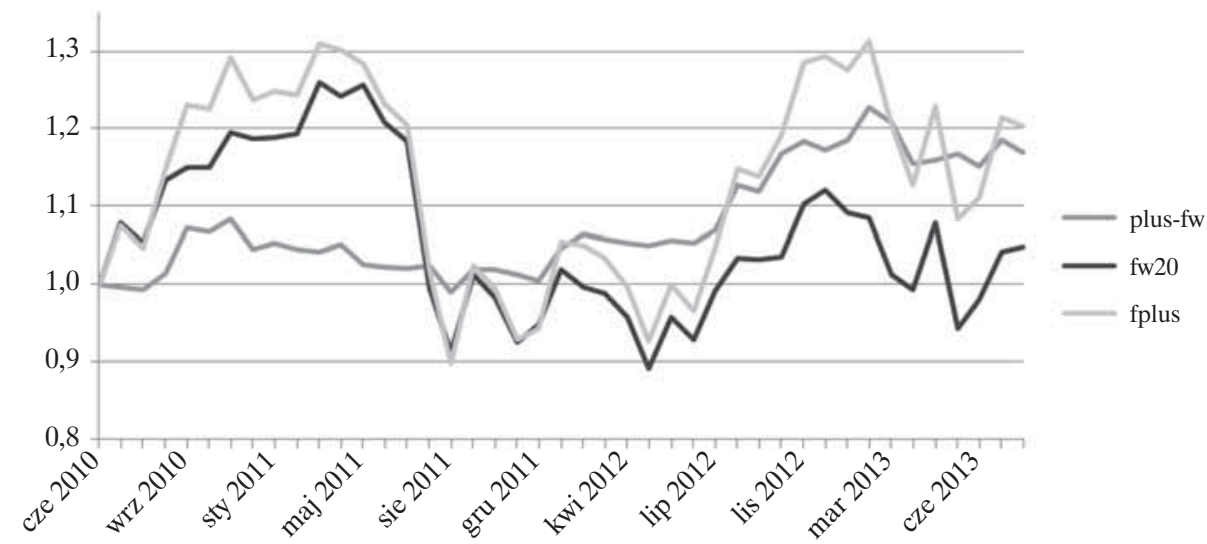

Źródło: opracowanie własne.

zbliżone do zakładanego poziomu 5 punktów procentowych. Warto również wspomnieć, że realny zysk z tego typu strategii jest znacznie wyższy, ponieważ obracając tylko kontraktami terminowymi, stosuje się lewarowanie, więc faktyczny zysk ze strategii kształtuje się na znacznie wyższym poziomie.

Również statystyki charakteryzujące analizowane dane wskazują na osiągnięcie przez strategię pożądanych rezultatów. Odchylenia standardowe stóp zwrotu portfela indeks plus oraz kontraktów terminowych na WIG20 wznoszą odpowiednio 12,47 oraz 5,69\%, podczas gdy dla strategii long-short poziom ten wynosi $2,21 \%$. Jest to niezwykle ważne, ponieważ oznacza, że strategia ta realizuje stabilne wyniki inwestycyjne. Poziom skrelowania jej z benchmarkiem, kontraktami terminowymi na WIG20 jest na poziomie 0,34, co można uznać za niski poziom, który potwierdza, że jest to strategia typu market neutral.

\section{Wnioski}

Otrzymane wyniki dotyczące długookresowej zależności analizowanych walorów pozwalają na wyciągnięcie kilku interesujących wniosków. Istnieje równowaga pomiędzy cenami kontraktów terminowych na akcje wchodzące w skład indeksu WIG20 a derywatami na niego. Dzięki wyznaczeniu tych relacji można modelować zarówno strategie replikujące zachowanie się samego indeksu, jak i przewyższające jego stopy zwrotu. W wyniku zastoso- 
wania strategi typu market neutral można otrzymać portfel nie tylko generujący dodatnie, niezależne od rynku stopy zwrotu, lecz także charakteryzujący się bardzo małą ich zmiennością. Niezwykle ważną cechą zaprezentowanego portfela absolutnej stopy zwrotu jest utrzymywanie jego skumulowanych zysków na dodatnim poziomie przez niemal cały okres weryfikacyjny. Wyniki badań mogą być szczególnie ciekawe dla rodzimych funduszy inwestycyjnych projektujących swoje strategie zarządzania portfelem dla poszukiwania absolutnych stóp zwrotu. Otrzymane wyniki są zgodne z zaprezentowaną literaturą i zachęcają do dalszych badań tego zagadnienia. Prawdopodobnie można otrzymać lepsze odwzorowanie, optymalizując okresy testowe dla wyznaczenia zależności kointegracyjnych.

\section{Bibliografia}

Alexander, C., Giblin, I., i Weddington, W. (2002). Cointegration and asset allocation: a new active hedge fund strategy, Research in International Business and Finance, 16, 65-90.

Alexander, C.O. (1999). Optimal hedging using cointegration, Philosophical Transactions of the Royal Society, A 357, 2039-2058

Alexander, C.O. i Dimitriu, A. (2002). The Cointegration Alpha: Enhanced Index Tracking and Long-Short Equity Market Neutral Strategies, Discussion Paper 2002-08, ISMA Centre Discussion Papers in Finance Series.

Arendarski, P. i Postek, L. (2012). Cointegration Based Trading Strategy For Soft Commodities Market, Working Papers 2012-02, Faculty of Economic Sciences, University of Warsaw.

Elton, E.J. i Gruber, M.J. (1998). Nowoczesna teoria portfelowa i analiza papierów wartościowych. Warszawa: WIG Press.

Engle, R.F. i Granger, C.W.J. (1987). Cointegration and error correction: representation, estimation and testing, Econometrica, 55, 251-276

Johansen, S. (1995). Likelihood - Based Inference in Cointegrated Vector Autoregressive. New York: Oxford University Press.

Lucas, A. (1997). Strategic and Tactical Asset Allocation and the Effect of Long-Run Equilibrium Relations, Research Memorandum Vrije Universiteit Amsterdam, 42. 


\title{
Rozdział XII
}

\author{
RENATA KARKOWSKA* \\ KATARZYNA NIEWIŃSKA**
}

\section{Niestabilność współczynnika beta w sektorze finansowym}

\section{- analiza dla wybranych rynków europejskich}

\begin{abstract}
Streszczenie
Ostatni kryzys finansowych 2008-2009 pokazał, jak trudne może być zarządzanie ryzykiem systematycznym na rynku kapitałowym. Tym bardziej, że efekt zarażania powoduje brak skutecznej dywersyfikacji aktywów portfela inwestycyjnego. Wiedza, jak reagują akcje spółek wchodzących w skład portfela inwestycyjnego okazuje się szczególnie istotna w warunkach dużej zmienności indeksów giełdowych. Mając na uwadze powyższe problemy, w artykule postawiono następujące hipotezy badawcze: (1) ryzyko systematyczne wśród spółek sektora finansowego w Europie wykazuje zróżnicowanie czasowo-przestrzenne; (2) wartości współczynnika beta w okresie dekoniunktury są wyższe niż w fazie wzrostów; (3) okres hossy giełdowej sprzyja niedoszacowaniu ryzyka w sektorze finansowym. Badanie zostało przeprowadzone dla spółek sektora finansowego, wchodzących w skład wybranych indeksów giełdowych w Europie w okresie 2003-2013.
\end{abstract}

Słowa kluczowe: współczynnik beta, model jednowskaźnikowy Sharpe’a, ryzyko systematyczne.

\begin{abstract}
The last financial crisis of 2008-2009 showed how difficult the management of the systematic risk on the capital market can be. Knowledge of how the shares of companies included in the investment portfolio react, is particularly important in the environment of high volatility of market indexes. Taking into consideration the above mentioned issues, the following hypotheses in this paper were proposed: (1) the systematic risk of the financial sector in Europe is time-space differentiated, (2) the value of the beta measures during recession are higher than in the phase of growth, (3) during

* Dr Renata Karkowska - Katedra Systemów Finansowych Gospodarki, Wydział Zarządzania, Uniwersytet Warszawski; e-mail: rkarkowska@wz.uw.edu.pl.

** Mgr Katarzyna Niewińska - Katedra Systemów Finansowych Gospodarki, Wydział Zarządzania, Uniwersytet Warszawski; e-mail: kniewinska@wz.uw.edu.pl.
\end{abstract}


the time of the bull market the risk in the financial sector if often underestimated. The study was conducted for the financial sector companies included in the selected stock market indexes in Europe.

Keywords: beta coefficient, Share Single Index model, systematic risk.

\section{Wstęp}

Nowoczesna analiza portfelowa związana jest ściśle z procesem podejmowania decyzji inwestycyjnych. Zajmuje się wyborem portfela efektywnego, który dla danego inwestora będzie portfelem optymalnym, czyli zgodnym z jego preferencjami odnośnie do oczekiwanej stopy zwrotu i ryzyka. Dzięki wykorzystaniu metod nowoczesnej analizy portfelowej inwestorzy mogą budować portfele odpowiadające ich preferencjom, co do stopy zwrotu i ryzyka. Jednak należy pamiętać, iż to podejście opiera się na danych historycznych, które zgodnie z hipotezami efektywnego rynku nie powinny dawać możliwości osiągania większych zysków. Mimo to, wykorzystanie nowoczesnej analizy portfelowej może być potencjalnie źródłem cennych danych, ułatwiających wybór efektywnych portfeli. Prosta zasada inwestycyjna, wykorzystująca historyczne poziomy współczynników beta, mierzących ryzyko rynkowe, ogranicza się do wyboru walorów agresywnych, czyli wzrastających więcej niż indeks w okresach dobrej koniunktury oraz defensywnych, czyli tracących mniej niż rynek w okresach spadkowych.

Całkowite ryzyko portfela można podzielić na dwie części: systematyczne i specyficzne. O ile ryzyko specyficzne jest charakterystyczne dla danego waloru lub jego emitenta, podlega dywersyfikacji, a zmienność cen jest statystycznie niezależna od siebie, o tyle ryzyko systematyczne określa się mianem ryzyka niedywersyfikowalnego i wynika z czynników oddziałujących jednocześnie na zmiany cen na całym rynku, tj. przemiany gospodarcze czy polityczne. Wahania te wynikają z zewnątrz i są niezależne od podmiotu gospodarczego. Większość papierów wartościowych reaguje na te zmiany z podobną siłą. Tę stosunkowo prostą zależność wskazał Sharpe (1964), rozwijając model jednowskaźnikowy (Single Index Model). Współczynnik beta prezentowany w modelu Sharpe'a jest miarą reakcji ceny danych papierów wartościowych na zmiany cen rynkowych. Można zatem wykorzystać szacunki wskaźnika beta do określenia ryzyka systematycznego dla danych walorów.

$\mathrm{Z}$ punktu widzenia niniejszego badania interesować nas będzie niestabilność współczynnika beta w różnych okresach koniunktury, dla spółek sektora finansowego na wybranych rynkach europejskich. Wybór próby badawczej był podyktowany istotną niestabilnością cen walorów sektora finansowego 
podczas ostatniego kryzysu finansowego. Może to również okazać się istotne z punktu widzenia ryzyka systemowego sektora finansowego. Jak dotąd nie ma idealnych miar tego ryzyka, mimo poczynionych znaczących badań w tym kierunku. Artykuł składa się z pięciu części: wstępu, przeglądu literatury i zasadności podjętego badania, opisu przyjętej metody badawczej i wykorzystanych danych, prezentacji uzyskanych wyników oraz podsumowania i wniosków.

\section{Przegląd literatury}

Jedne z pierwszych badań, gdzie została udowodniona empirycznie niestabilność współczynnika beta w czasie, przeprowadził M. Blume (1971). W następnych badaniach, przeprowadzonych przez R. Levy'ego (1974) oraz F. Fabozziego i J. Francisa (1978), poruszono kwestię niestabilności współczynnika beta w okresach wzrostów/spadków na rynku giełdowym. Badanie Levy'ego bazowało na akcjach 500 spółek notowanych na NYSE w okresie 1960-1970. Wyniki, jakie uzyskał, potwierdzały istotność stosowania oddzielnych kalkulacji współczynnika beta w różnych fazach koniunktury giełdowej. Wahania ryzyka systematycznego na rynku kapitałowym interesowały również M. Kim i K. Zumwalta (1979). Rezultatem badania było twierdzenie, że inwestorzy odmiennie podejmują ryzyko w okresach spadków niż wzrostów rynkowych. W związku $\mathrm{z}$ tym estymacja współczynników beta dla tego samego aktywa istotnie różni się w zależności od nastrojów inwestorów. A. Odabaşı (2003) oszacował zmiany współczynnika beta w latach 1992-1999 dla giełdy w Istambule, gdzie dla 8-letniego badanego okresu beta jest niestabilna w $80 \%$, natomiast dla krótszego podokresu - czteroletniego - już tylko 65\%. Badania z wykorzystaniem modelu CAPM dla 10 spółek notowanych na giełdzie w Bukareszcie, w okresie od stycznia do lipca 2009 roku, przeprowadzili również R. Stefanescu, C. Nistori i R. Dumitriu (2009), dowodząc, że optymizm inwestorów w czasie hossy powoduje wyższe wartości współczynnika beta. Odwrotnie dzieje się natomiast w okresach bessy. Zmienność ryzyka systematycznego w sektorze bankowym dla rynków rozwiniętych estymowali S. Mergner i J. Bulla (2008), M. King (2009) oraz T. Caporale (2012), dowodząc z kolei, że wartości współczynników beta dla spółek finansowych są niedoszacowane w okresach dobrej koniunktury. Przyczyną powyższego może być prawdopodobnie niższy koszt pozyskania kapitału i wyższy poziom dźwigni finansowej stosowanej przez banki. Bardziej rozwinięte badanie przeprowadzili T. Adam i I. Jánský (2012). Opierało się ono na oszacowaniu zmienności bety dla sektorów bankowych w ośmiu 
wysoko rozwiniętych krajach dla lat 1999-2012 za pomocą modelu Bayesa. Badanie to również dowiodło, że okresach bessy na rynku współczynnik beta był bardzo wysoki.

Podjęta przez autorów analiza zmienności ryzyka systematycznego w spółkach finansowych, w okresie 10 lat, obejmuje swoim zakresem fazy hossy i bessy na rynku kapitałowym oraz uwzględnia kraje o różnym poziomie rozwoju gospodarczego - Polskę, Czechy, Hiszpanię, Francję i Wielką Brytanię. Według najlepszej wiedzy autorów, analiza o takich przekroju czasowo-przestrzennym wypełnia lukę w dotychczas przeprowadzonych badaniach.

\section{Metoda badawcza i opis danych}

W teorii finansów klasyczną miarą ryzyka jest wariancja. Ma ona jednak pewne wady, mianowicie jednakowo traktuje zmiany zarówno ujemne, jak i dodatnie w stosunku do średniej. W celu zmierzenia efektywności portfela odchylenia ujemne są niepożądane. Dlatego dla estymacji zmian ujemnych H. Markowitz (1959) zaproponował semiwariancję, która jest średnią odchyleń poniżej pewnego poziomu:

$$
d s_{i}^{2}(l)=\frac{\sum_{t=1}^{m} d_{i t}^{2}(l)}{m-1},
$$

gdzie,

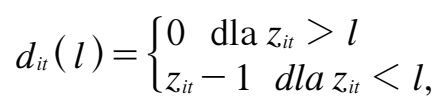

$z_{i t} \quad-$ stopa zwrotu w $t$ okresie dla $i$-tej spółki,

$d s_{i}^{2}(l)$ - semiwariancja,

$m$ - liczba okresów,

$l \quad-$ równe średniej stopie zwrotu.

Jeżeli zadana stopa zwrotu będzie stopą wolna od ryzyka, możemy uzyskać semiwariancję dla stopy wolnej od ryzyka:

$$
d s_{i}^{2}(g)=\frac{\sum_{t=1}^{m} d_{i t}^{2}(g)}{m-1},
$$


gdzie,

$$
d_{i t}(g)= \begin{cases}0 & \text { dla } z_{i t}>z_{f} \\ z_{i t}-z_{f} & \text { dla } z_{i t}<z_{f}\end{cases}
$$

$z_{f}$ - stopa zwrotu wolna od ryzyka w $t$ okresie.

Semiwariancja mierzy zatem tylko dolnostronną zmienność stóp zwrotu.

Uogólnieniem semiwariancji jest zdefiniowanie dolnych momentów częściowych przez P. Fishburna (1977) i V. Bawę (1975). Dolny moment $n$-tego stopnia jest równy:

$$
\operatorname{LPM}_{i}^{n}(f)=\frac{\sum_{t=1}^{m} d_{i t}^{n}(f)}{m-1} .
$$

Przyjęcie wariancji jako miary ryzyka jest podstawą klasycznej miary wspó1czynnika beta $\beta$. Wielu autorów natomiast wyznacza dolnostronne współczynniki $\beta$, różnicując je ze względu na punkt odniesienia, tj. zadana stopa zwrotu czy średnia stopa wolna od ryzyka (Rutkowska-Ziarko 2010; Estrada 2007).

W niniejszej pracy przyjęto klasyczne współczynniki beta według standardowego modelu Sharpe'a.

Model jednowskaźnikowy Sharpe’a opiera się na założeniu, iż jedynym czynnikiem makroekonomicznym występującym na rynku kapitałowym jest stopa zwrotu indeksu rynkowego. Wzrost wartości indeksu rynkowego powinien prowadzić do wzrostu wartości stóp zwrotu większości akcji, jego spadek zaś analogicznie - do zniżek ich wartości.

Zależność stóp zwrotu akcji od stopu zwrotu indeksu rynkowego została opisana wzorem:

$$
R_{i t}=\alpha_{i t}+\beta_{i t} R_{M t}+\varepsilon_{t}, \quad \varepsilon_{t} \sim N(0, Q)
$$

gdzie:

$R_{i t} \quad$ - stopa zwrotu $i$-tej akcji,

$R_{M t} \quad$ - stopa zwrotu indeksu rynkowego,

$\alpha_{i b} \beta_{i t}$ - parametry równania,

$\varepsilon_{t} \quad$-składnik losowy równania.

Zależność pokazuje, że na ryzyko związane ze stopą zwrotu z danego waloru składają się dwa elementy: $\beta R_{M t}$, który jest wielokrotnością stopy 
dochodu $\mathrm{z}$ indeksu i nazywany jest ryzykiem systematycznym oraz $\varepsilon$, który nie wykazuje żadnego związku z portfelem rynkowym i jest ryzykiem niesystematycznym (Hull 2011, s. 31).

W celu estymacji współczynnika beta w okresach wzrostów i spadków rynkowych wykorzystano model DBMM - Dual Beta Market Model (Bhaduri i Durai 2006, s. 57).

$$
R_{i, t}=\alpha_{i}+\beta_{i 1} * Z_{1} * R_{\text {index } K_{-}}+\beta_{i 2} * Z_{2} * R_{\text {index } K_{-} t}+\varepsilon_{i t},
$$

gdzie:

$Z_{1}=1$ dla wzrostu indeksu i 0 dla spadku indeksu,

$Z_{2}=0$ dla wzrostu indeksu i 1 dla spadku indeksu,

$\beta_{i 1}$ - beta dla wzrostu rynkowego,

$\beta_{i 2}$ - beta dla spadku rynkowego,

$R_{i, t}, R_{\text {indexK_t }}$ - odpowiednio stopy zwrotu dla waloru $i$ i indeksu $K$ w czasie $t$.

W badaniu zostaną poddane analizie tygodniowe stopy zwrotu spółek finansowych z głównych indeksów giełdowych z wybranych pięciu europejskich rynków giełdowych - Polski, Czech, Francji, Hiszpanii i Wielkiej Brytanii. Przyjęty został 10-letni okres badawczy (od 1 stycznia 2003 r. do 25 września 2013 r.). Kalkulacja tygodniowych stóp zwrotu była następująca:

$$
\mathrm{R}_{i, t}=\left(\ln \mathrm{P}_{i, t}-\ln \mathrm{P}_{i, t-1}\right) * 100,
$$

gdzie:

$\mathrm{R}_{i, t}$ - tygodniowa stopa zwrotu dla waloru $i$ w okresie $t$,

$\mathrm{P}_{i, t}$ - cena waloru $i$ w okresie $t$

$\mathrm{P}_{i, t-1} \quad$ - cena waloru $i$ w okresie $t-1$.

W celu uchwycenia zmian współczynnika beta dla okresów koniunktury i dekoniunktury rynkowej zostały wyodrębnione okresy spadków i wzrostów na poszczególnych giełdach. Przyjęto metodę 14-dniowej średniej ruchomej dla wyodrębnienia poszczególnych okresów. Dla WIG20 wyszczególniono następujące okresy wzrostów: 2003.01.01-2007.07.01; 2009.03.01-2011.06.17; 2012.06.01-2013.01.01; 2013.04.20-2013.09.25, zaś spadków: 2007.07.022009.02.27; 2011.06.18-2012.05.31; 2013.01.02-2013.04.20. Dla PX czas koniunktury trwał: 2003.01.01-2007.10.08; 2009.02.18-2011.06.14, a dekoniunktury: 2007.10.09-2009.02.17; 2011.06.15-2013.09.25. Indeks CAC40 
rósł między: 2003.01.01-2007.07.16; 2009.03.07-2011.04.29; 2011.11.242013.09.25, zaś spadał: 2007.07.17-2009.03.06; 2011.04.30-2011.11.23. IBEX 35 wzrastał w trakcie: 2003.01.01-2007.10.29; 2009.03.03-2009.12.01; 2012.05.31-2013.09.25 i malał w okresach: 2007.10.30-2009.03.02; 2009.12.02-2012.05.30. FTSE100 wzrastał: 2003.01.01-2007.07.19; 2009.03.03-2013.09.25, a spadał od 2007.07.20-2009.03.02.

Współczynniki korelacji oraz statystyki opisowe wybranych indeksów zostały zaprezentowane w tabelach 1 i 2 .

Wartości indeksów zostały zobrazowane na wykresach szeregów czasowych (por. rys. 1).

Ta b e la 1. Współczynniki korelacji liniowej dla obserwacji z próby 2003.01.02-2013.09.25

\begin{tabular}{|l|c|c|c|c|l|}
\hline WIG20 & PX & CAC40 & IBEX35 & FTSE100 & \\
\hline 1,0000 & 0,9337 & 0,8340 & 0,8679 & 0,8955 & WIG20 \\
\hline & 1,0000 & 0,9034 & 0,9338 & 0,7814 & PX \\
\hline & & 1,0000 & 0,8874 & 0,6595 & CAC40 \\
\hline & & & 1,0000 & 0,6579 & IBEX35 \\
\hline & & & & 1,0000 & FTSE100 \\
\hline
\end{tabular}

Uwaga: wartość krytyczna (przy dwustronnym 5\% obszarze krytycznym) $=0,0378$ dla $\mathrm{n}=2689$.

Źródło: Thomson Reuters.

Ta b e l a 2. Statystyki opisowe dla obserwacji z próby 2003.01.02-2013.09.25

\begin{tabular}{|l|c|c|c|c|}
\hline \multicolumn{1}{|c|}{ Zmienna } & Średnia & Mediana & Minimalna & Maksymalna \\
\hline WIG20 & 2370,19 & 2352,88 & 1069,72 & 3917,87 \\
\hline PX & 1137,28 & 1136,40 & 459,600 & 1936,90 \\
\hline CAC40 & 4015,12 & 3782,20 & 2403,04 & 6168,15 \\
\hline IBEX35 & 10036,60 & 9668,90 & 5452,40 & 15945,70 \\
\hline FTSE100 & 5337,63 & 5489,16 & 3287,04 & 6840,27 \\
\hline \multicolumn{1}{|c|}{ Zmienna } & $\begin{array}{c}\text { Odchylenie } \\
\text { standardowe }\end{array}$ & $\begin{array}{c}\text { Współczynniki } \\
\text { zmienności }\end{array}$ & Skośność & Kurtoza \\
\hline WIG20 & 637,191 & 0,268836 & 0,210866 & $-0,358898$ \\
\hline PX & 350,106 & 0,307845 & 0,217538 & $-0,623248$ \\
\hline CAC40 & 842,545 & 0,209843 & 0,758228 & $-0,349597$ \\
\hline IBEX35 & 2445,94 & 0,243702 & 0,539318 & $-0,528472$ \\
\hline FTSE100 & 784,134 & 0,146907 & $-0,378448$ & $-0,862312$ \\
\hline
\end{tabular}

Źródło: Thomson Reuters. 
Ry su n e k 1. Wartości cen indeksów WIG20, PX, CAC40, IBEX35, FTSE100 w okresie 2003/01/02-2013/09/25

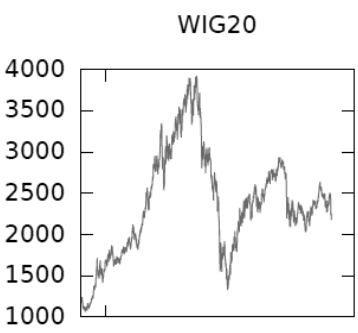

IBEX35

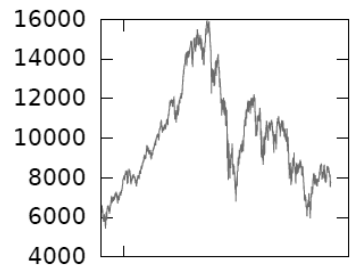

PX

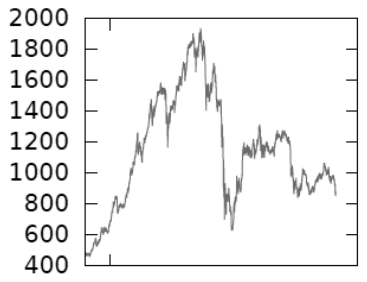

FTSE100

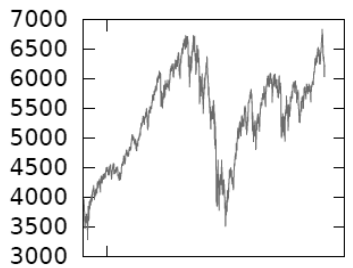

CAC40

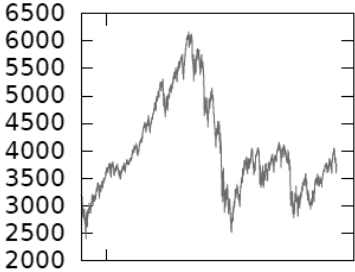

Źródło: Thomson Reuters.

Dla celów badania zostały wybrane indeksy typu cenowego, tak aby dochody z tytułu dywidend nie powodowały zaburzeń w kształtowaniu się wartości indeksu. WIG20 jest publikowany na GPW w Warszawie, a jego wielkość jest szacowana na podstawie 20 największych i najbardziej płynnych spółek. Indeks PX jest oficjalnym indeksem parkietu w Pradze i obejmuje 50 największych spółek. Z paryskiego parkietu Euronext do analizy został wybrany indeks CAC40, który skupia 40 akcji największych i najbardziej płynnych spółek. Rynek hiszpański reprezentuje indeks IBEX35, który został stworzony dla największych i najbardziej płynnych 35 spółek na madryckiej giełdzie. Ostatnim indeksem wybranym do badania jest FTSE 100. Jest to indeks 100 największych brytyjskich spółek pod względem ich kapitalizacji i płynności (84,35\% kapitalizacji rynku akcji w Wielkiej Brytanii). Kształtowanie się cen wybranych indeksów zostało zobrazowane na rysunkach 2-6.

$\mathrm{Z}$ każdego rynku zostały wybrane spółki z sektora finansowego, wchodzące w skład głównego indeksu. Łącznie w badaniu zostało poddane analizie 37 spółek finansowych z 5 rynków europejskich, obejmujących swoim spektrum zarówno kraje dojrzałe, jak i rozwijające się. Źródłem danych na temat cen akcji spółek wchodzących w skład poszczególnych indeksów giełdowych zostały zaczerpnięte z aplikacji Eikon Thomson Reuters. 
Rys u n e 2. Rozkład współczynnika beta dla giełdy warszawskiej

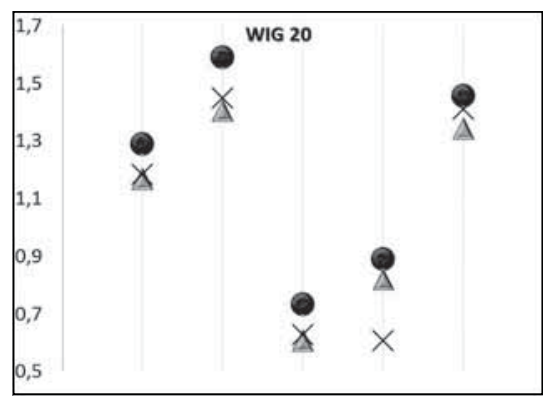

Źródło: opracowanie własne.

Ry s u n e 4. Rozkład współczynnika beta dla giełdy londyńskiej

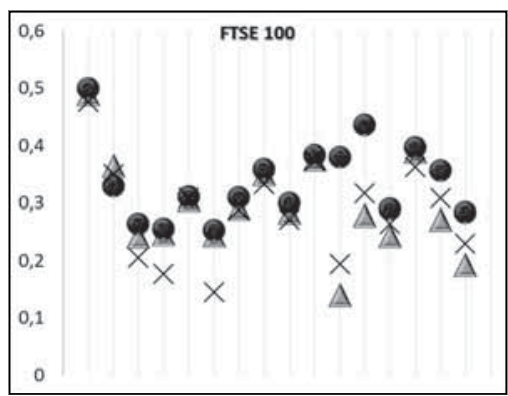

Źródło: opracowanie własne.

Ry s u n e k. Rozkład współczynnika beta dla giełdy paryskiej

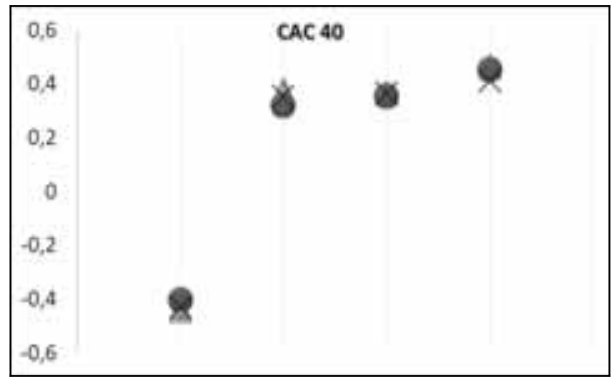

Źródło: opracowanie własne.
Ry s u n e k 3. Rozkład współczynnika beta dla giełdy hiszpańskiej

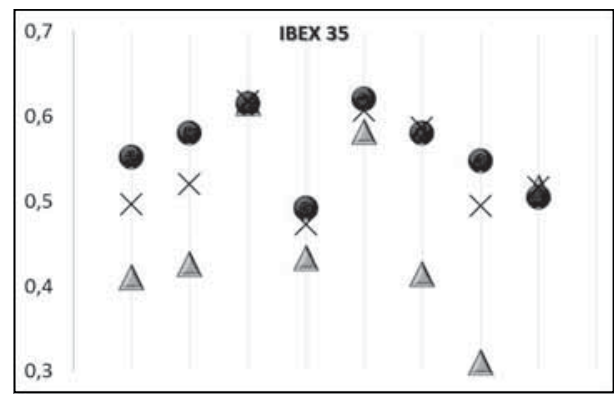

Źródło: opracowanie własne.

Ry s u n e 5. Rozkład współczynnika beta dla gietdy praskiej

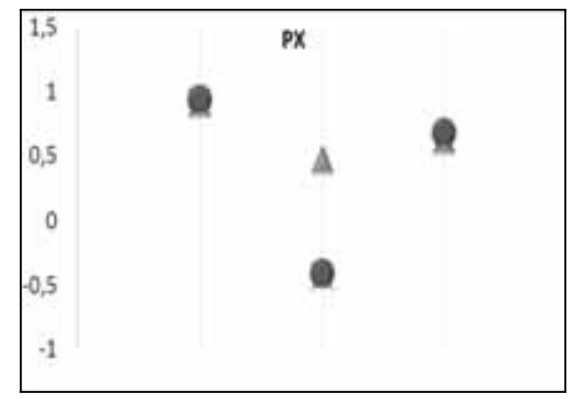

Źródło: opracowanie własne.

$\Delta$ beta - wzrosty indeksu

beta - spadki indeksu

$\times$ beta - pełny okres 


\section{Wyniki badań}

Wyniki przeprowadzonego badania zostały zaprezentowane w tabeli 3, a ich graficzne obrazy na rysunkach 2-6. Wartości współczynnika beta dla każdej spółki finansowej wchodzącej w skład danego indeksu zostały przedstawione w podziale dla okresu wzrostu i spadku koniunktury. Analiza wykazała, że:

1) wszystkie wartości parametru beta są istotnie statystycznie, co sygnalizuje wysoką stabilność otrzymanych wyników;

2) w większości przypadków współczynnik beta przyjmował wartości dodatnie, co oznacza, że zwrot zmian ceny danego waloru i indeksu był tożsamy; wyjątek stanowiły spółki Erste Group z rynku praskiego i AXA z rynku francuskiego;

3) spółki sektora finansowego z krajów mniej rozwiniętych, tj. Polski i Czech okazały się najbardziej ofensywne, wartości beta przyjmowały tam wartości z przedziału $0,55-1,5$;

4) z kolei spółki z rynków dojrzałych (zob. indeks FTSE100) cechuje defensywna reakcja zmian cen akcji na zmianę indeksu, tj. wartość parametru beta przyjmuje wartości mniejsze od 1 ;

5) wartości współczynnika beta dla okresów dekoniunktury były wyższe niż w okresach prosperity; najwięcej traciły banki na rynkach rozwijających się, tj. Polski, Czech, ale również Hiszpanii.

\section{Podsumowanie i wnioski}

Informacja o fluktuacji ryzyka systematycznego w różnych fazach cyklu giełdowego i na różnych rynkach kapitałowych może okazać się cenną dla inwestorów zarządzających portfelem akcji. Osiągnięte wyniki potwierdzają, że niestabilność współczynnika beta, podobnie jak na rynku amerykańskim, występuje również na europejskim rynku kapitałowym. Wzięcie pod uwagę tego faktu w procesie podejmowania decyzji może wpłynąć na podniesienie efektywności podejmowanych decyzji inwestycyjnych.

Przeprowadzone badanie potwierdziło postawioną wstępnie hipotezę o istotnym zróżnicowaniu wielkości współczynnika beta dla spółek sektora finansowego na wybranych rynkach europejskich. W przypadku negatywnych informacji z giełdy, stopy zwrotu spółek finansowych reagowały silniej, niż wynikałoby to z wartości współczynnika beta dla pełnego okresu próby. 


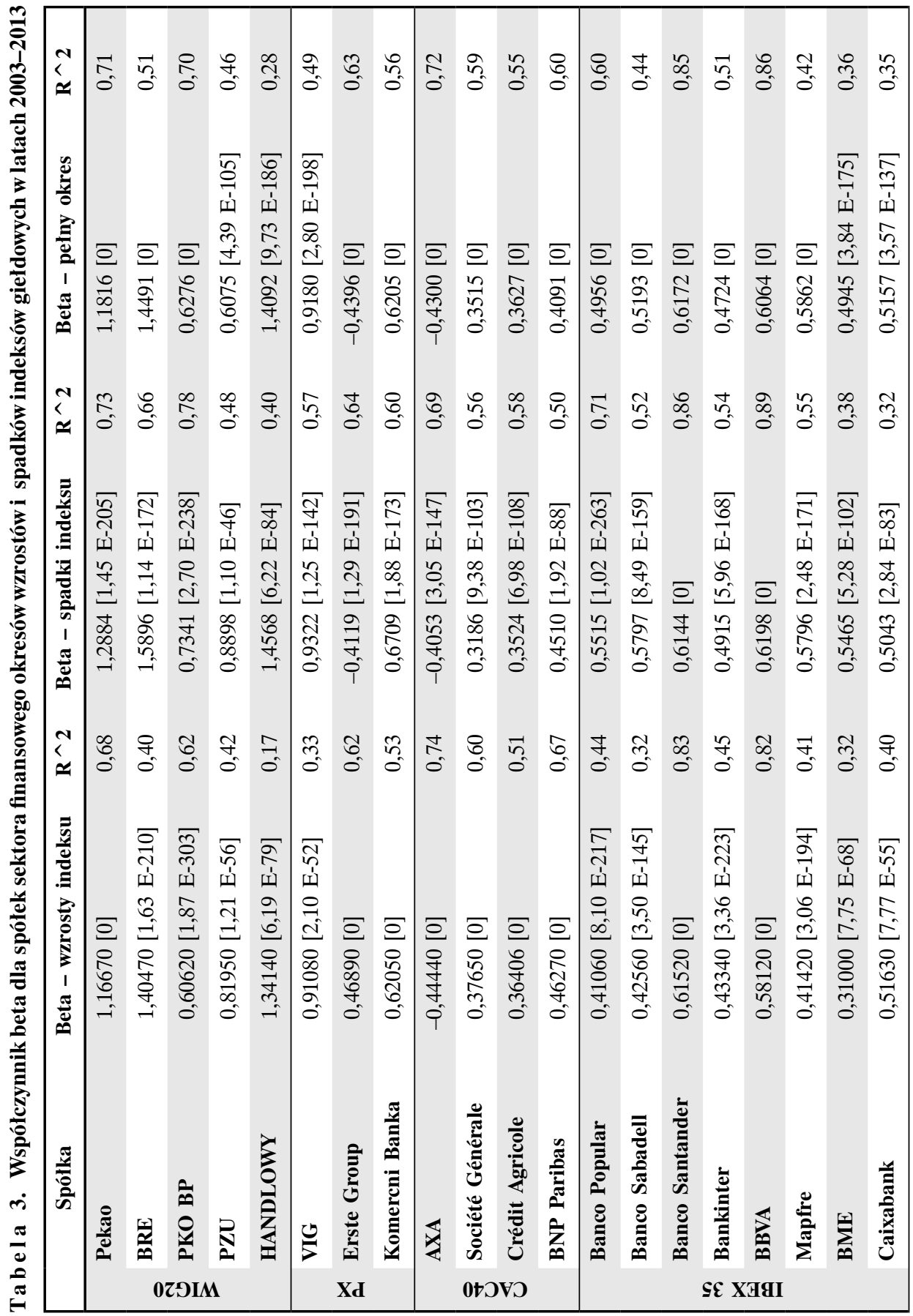




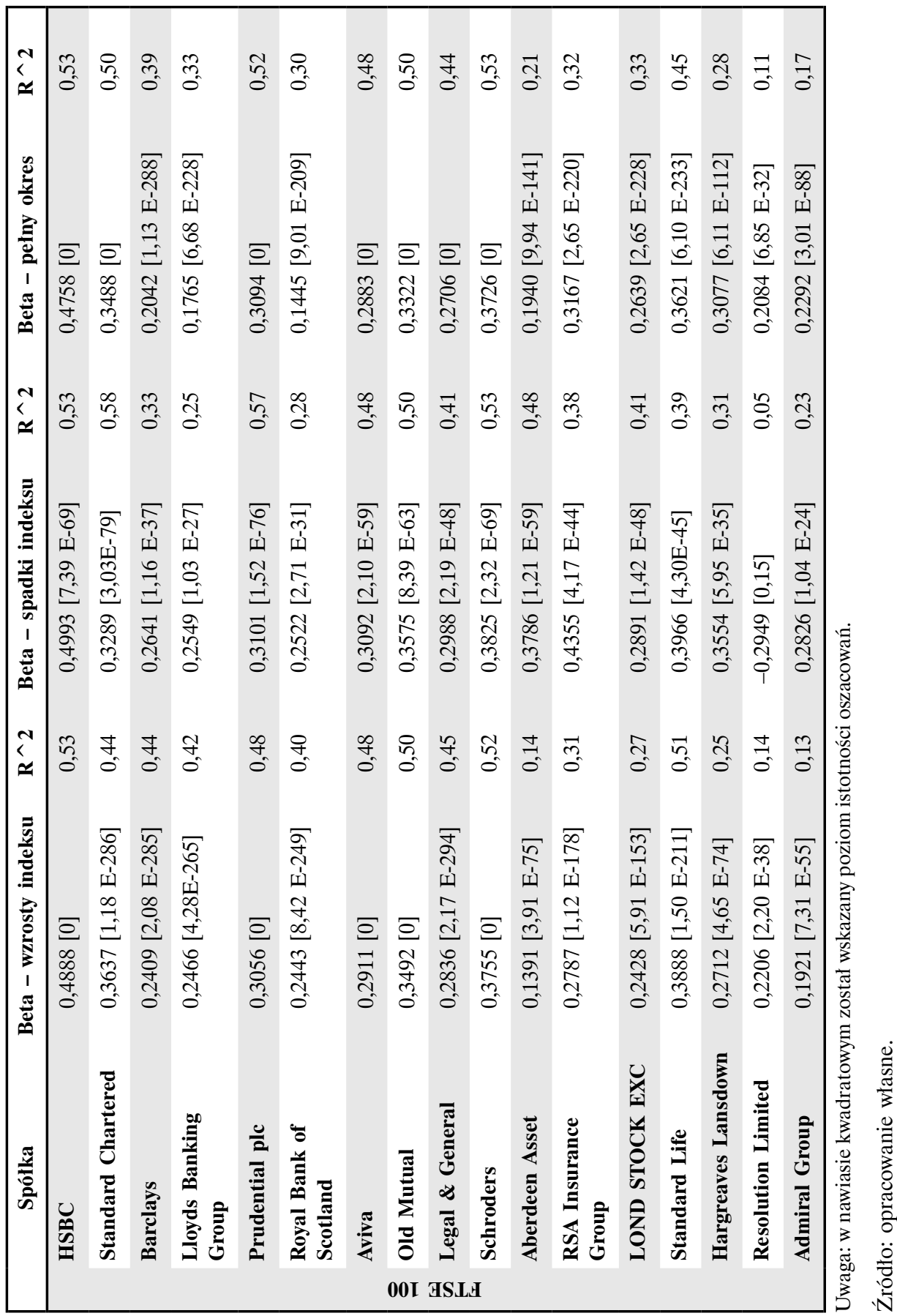


Innymi słowy, w fazie spadków spółki finansowe traciły więcej niż w fazie wzrostów. Oznacza to również, że inwestorzy niedoszacowywali ryzyka systematycznego w okresie hossy giełdowej. Istotnym jest również, że zjawisko niestabilności parametru beta w większym stopniu towarzyszy rynkom rozwijającym się, tj. w Polsce, Czechach, Hiszpanii. Różnice w wysokości parametru beta na rynkach rozwiniętych okazały się stosunkowo niższe. Wydaje się, że przyczyna zróżnicowania geograficznego współczynnika beta może leżeć $\mathrm{w}$ rodzaju stosowanych strategii inwestycyjnych, niskim poziomie rozwoju rynku kapitałowego w krajach słabiej rozwiniętych oraz kłopotów $\mathrm{z}$ utrzymaniem płynności $\mathrm{w}$ wyniku ponadprzeciętnego spadku indeksów giełdowych.

\section{Bibliografia}

Adam, T. i Jánský, I. (2012). Banking Betas in Times of Financial Instability. IES FSV UK. Bawa, V. (1975). Optimal rules for ordering uncertain prospects, Journal of Financial Economics, 2(1), 95-121.

Bhaduri, S., Durai, S. (2006). Asymmetric beta in bull and bear market conditions: evidences from India, Applied Financial Economics Letter, 2, 55-59.

Blume, M. (1971). On the Assessment of Risk, Journal of Finance, 26, 1-10.

Caporale, T. (2012). Time varying capm betas and banking sector risk, Economics Letters, 115(2), 293-295.

Estrada, J. (2007). Mean-semivariance behavior: Downside risk and capital asset pricing, International Review of Economics \& Finance, 16, 169-185.

Fabozzi, F. i Francis, J. (1978). Beta as a random coefficient, Journal of Financial and Quantitative Analysis, 13(1), 101-116.

Fishburn, P. (1977). Mean-risk analysis with risk associated with below-target returns, The American Economic Review, March, 116-126.

Hull, J. (2011). Zarzadzanie ryzykiem instytucji finansowych. Warszawa: PWN.

King, M. (2009). The cost of equity for global banks: a CAPM perspective from 1990 to 2009, BIS Quarterly Review, 59.

Kim. M. i Zumwaltay, K. (1979). An Analysis of Risk in Bull and Bear Markets, Journal of Financial and Quantitative Analysis, 14(5), 1015-1025.

Levy, R. (1974). Beta Coefficients as Predictors of Return, Financial Analysts Journal, January-February.

Markowitz, H. (1959). Porfolio selection: efficient diversification of investments. New York: John Wiley and Sons.

Mergner, S. i Bulla, J. (2008). Time-varying beta risk of pan-european industry portfolios: A comparison of alternative modeling techniques, The European Journal of Finance, 14(8), 771-802.

Odabaş1, A. (2003). An Investigation of Beta Instability in the Istanbul Stock Exchange, The Istanbul Stock Exchange Review, Istanbul. 
Rutkowska-Ziarko, A. (2010). Wykorzystanie dolno stronnych wspótczynników beta $w$ analizie ryzyka systematycznego na GPW $w$ Warszawie $w$ warunkach zmiennej koniunktury, Acta Universitatis Nocolai Copernici, Ekonomia XLI, Nauki Humanistyczno-Społeczne, Zeszyt 397.

Sharpe, W. (1964). Capital Assets Prices: A Theory of Market Equilibrium Under Conditions of Risk, The Journal of Finance XIX, September.

Stefanescu, R., Nistor, C. i Dumitriu R. (2009). Asymmetric responses of CAPM - beta to the bull and bear markets on the Bucharest Stock Exchange, Annals of the University of Economics, 9(4). 


\title{
Rozdział XIII
}

TOMASZ JEDYNAK*

\section{Ocena efektywności strategii inwestycji społecznie odpowiedzialnych na przykładzie wyników polskich funduszy inwestycyjnych}

\begin{abstract}
Streszczenie
W opracowaniu dokonano weryfikacji hipotezy stanowiącej, iż efektywność inwestycji opartych na strategii SRI nie odbiega w sposób istotny od efektywności klasycznych strategii inwestycyjnych. Badanie przeprowadzono na grupie 82 funduszy akcyjnych dostępnych w Polsce, spośród których 4 fundusze deklarują stosowanie strategii SRI. Z pomiędzy pozostałych 78 funduszy wylosowano 10, które stanowiły podstawę skonstruowania benchmarku dla funduszy stosujących strategię SRI. Przeprowadzone badania wykazały, że przeciętna stopa zwrotu osiągana przez fundusze deklarujące stosowanie strategii SRI nie różniła się istotnie od tej osiąganej przez fundusze stosujące klasyczne strategie inwestycyjne. W przypadku trzech z czterech badanych funduszy SRI, wariancja ich stopy zwrotu była statystycznie różna od wariancji stopy zwrotu z przyjętego benchmarku. Ze względu na krótki okres badawczy analiza miar efektywności opartych na modelu CAPM nie dała rezultatów, które można uznać za wyczerpujące i wiarygodne. Ostatecznie stwierdzono, iż rezultaty przeprowadzonych badań nie dostarczają dostatecznych podstaw, aby odrzucić przyjętą hipotezę badawczą. W celu jej ostatecznej weryfikacji konieczne jest przeprowadzenie dalszych, pogłębionych badań w tym zakresie.
\end{abstract}

Słowa kluczowe: inwestycje społecznie odpowiedzialne, SRI, efektywność inwestycji, fundusze inwestycyjne.

\footnotetext{
Abstact

Evaluation of the effectiveness of socially responsible investment strategy on the example of the performance of Polish investment funds. The study was to verify the hypothesis which assumes that the effectiveness of investment strategies based on the SRI is not significantly different from the effectiveness of investment strategies which are considered classic. The research was conducted

* Mgr Tomasz Jedynak - Katedra Zarządzania Ryzykiem i Ubezpieczeń, Uniwersytet Ekonomiczny w Krakowie; e-mail: tomasz.jedynak@uek.krakow.pl.
} 
on a group of 82 equity funds available in Poland, of which four declare implementing the SRI strategy. Among 78 remaining funds, 10 were drawn to compile a benchmark for SRI funds. The study showed that the average rate of return achieved by SRI fund did not differ significantly from that achieved by the funds using classical investment strategies. For three of the four examined SRI funds, the variance of the rate of return was significantly different from the variance of the return on the benchmark. Due to the short period of research, analysis of performance measures based on the CAPM model did not give the results that can be considered to be complete and reliable. It was concluded that on the basis of the study there were no sufficient grounds to reject the main hypothesis. In order to final verification of that hypothesis it is necessary to conduct further, in-depth research in this area.

Keywords: Socially responsible investing, SRI, investment efficiency, investment funds.

\section{Wstęp}

Począwszy od lat dziewięćdziesiątych XX w. na świecie intensywnie rozwija się koncepcja inwestowania społecznie odpowiedzialnego (socially responsible investing, SRI), której podstawowym założeniem jest uwzględnianie w procesie podejmowania decyzji inwestycyjnych, poza kryteriami czysto finansowymi, również przesłanek o charakterze społeczno-etycznym, ekologicznym i środowiskowym. Idea ta w ostatnich latach nabrała szczególnego znaczenia w obliczu globalnego kryzysu finansowego zapoczątkowanego w Stanach Zjednoczonych, który ujawnił niedoskonałości strategii inwestycyjnych wywodzących się z klasycznej teorii portfela. Głównym celem opracowania jest weryfikacja hipotezy badawczej stanowiącej, iż efektywność inwestycji opartych na strategii SRI nie odbiega w sposób istotny od efektywności strategii inwestycyjnych uznawanych za tradycyjne. Dla realizacji tak zdefiniowanego celu określono zadania badawcze polegające na weryfikacji hipotez pomocniczych mówiących, iż (1) przeciętna stopa zwrotu osiągana przez fundusze stosujące strategię SRI nie różni się od stopy zwrotu osiąganej przez fundusze stosujące tradycyjne strategie inwestycyjne; (2) mierzone wariancją stopy zwrotu ryzyko funduszy stosujących strategię SRI jest statystycznie równe ryzyku ponoszonemu przez fundusze stosujące tradycyjne strategie inwestycyjne; (3) mierzona miarami opartymi na modelu CAPM efektywność funduszy stosujących strategię SRI jest równa efektywności funduszy stosujących tradycyjne strategie inwestycyjne. Zakres podmiotowy badania obejmuje 82 fundusze akcyjne funkcjonujące na polskim rynku kapitałowym, w tym 4 fundusze deklarujące stosowanie strategii SRI. Zakres przedmiotowy obejmuje natomiast stopy zwrotu generowane przez te fun- 
dusze w przyjętym okresie badawczym, tj. od 01.01.2008 do 31.12.2012 r. Uwzględniając empiryczny charakter opracowania, jako podstawową metodę badawczą zastosowano wnioskowanie statystyczne.

\section{Inwestycje społecznie odpowiedzialne w świetle dotychczasowych badań}

Pojęcie inwestycji społecznie odpowiedzialnych nie doczekało się dotychczas jednej, powszechnie uznawanej w literaturze definicji. Jeden z prekursorów koncepcji SRI, P. Kinder uważa, że inwestycje społecznie odpowiedzialne dotyczą wcielania kryteriów społecznych lub etycznych w proces podejmowania decyzji inwestycyjnych (Domini i Kinder 1984). Z kolei autorzy raportu Światowego Forum Ekonomicznego w Genewie z 2005 r. określają inwestycje społecznie odpowiedzialne jako ,inwestowanie w sposób biorący pod uwagę wpływ inwestycji na szeroko rozumiane społeczeństwo oraz środowisko naturalne zarówno dzisiaj, jak i w przyszłości" (World Economic Forum 2005). J.H. Langbein i R.H. Posner określają natomiast SRI jako „[inwestycje] dokonywane $\mathrm{z}$ wyłączeniem papierów wartościowych przedsiębiorstw postrzeganych jako nieodpowiedzialne społecznie z portfela inwestycyjnego, mimo iż z innego punktu widzenia mogą być atrakcyjne, oraz uwzględnianie w nim, określonych, $\mathrm{z}$ innego punktu widzenia nieatrakcyjnych przedsiębiorstw, które postępują w sposób godny społecznej pochwały" (Langbein i Posner 1980).

Nie wdając się w szczegółowe rozważania na temat definiowania SRI, stwierdzić należy, że termin „inwestycje społecznie odpowiedzialne” stanowi wspólne określenie dla szerokiej gamy strategii inwestycyjnych wykorzystujących oprócz kryteriów czysto finansowych również inne, niejednokrotnie niewymierne aspekty lokowania środków na rynku kapitałowym ${ }^{1}$. Przy czym podkreślić należy, że nie chodzi tutaj o pominięcie w analizie klasycznego, wywodzącego się z nowoczesnej teorii portfelowej pojęcia efektywności inwestycji, a raczej o jej uzupełnienie o dodatkowe czynniki jakościowe, takie jak aspekty środowiskowe, społeczno-etyczne, jakość zarządzania przedsiębiorstwem itp.

Okres dynamicznego rozwoju oraz gwałtownego wzrostu zainteresowania inwestorów inwestycjami społecznie odpowiedzialnymi na świecie rozpoczął

1 Zainteresowanych problematyką definiowania oraz istoty koncepcji inwestowania społecznie odpowiedzialnego autor odsyła do publikacji: Jedynak (2011a). 
się w latach dziewięćdziesiątych XX w. Wraz rosnącym uznaniem inwestorów, SRI przyciągnęły również uwagę środowiska akademickiego. Wśród badaczy brakuje jednak zgodności, co do wpływu stosowania strategii SRI na efektywność portfela. Z jednej strony, przykładowo J. Derwall i in. (2005) udowadniają, że czynniki pozafinansowe mogą wpływać na rentowność przedsiębiorstwa, co z kolei przekłada się również na ceny ich akcji. Z drugiej zaś - C. Geczy, R. Stambaugh i D. Levin (2003) wykazują, iż portfel stworzony w oparciu o strategię SRI charakteryzuje się niższą efektywnością od portfela rynkowego, a finansowe pobudki stosowania SRI są pozbawione podstaw. A. Gregory, J. Matako i R. Luther (1997) nie stwierdzili natomiast istotnych różnic pomiędzy funduszami SRI a grupą porównawczą. Do podobnych wniosków doszedł również Z. Bello (2005) oraz R. Bauer, J. Derwall i R. Otten (2007). Dotychczas niewielu polskich autorów podjęło problematykę inwestycji społecznie odpowiedzialnych oraz ich efektywności. Wśród prac poruszających analizowane zagadnienia wskazuje się m.in. na publikacje M. Czerwonki (2013), T. Czerwińskiej (2009), P. Kaźmierkiewicza (2010), D. Urbana (2011). Problematykę inwestycji społecznie odpowiedzialnych w Polsce poruszał również autor opracowania (Jedynak 2011; 2011a; 2012).

\section{Metodologia badań}

Problematyka porównania efektywności inwestycji społecznie odpowiedzialnych z efektywnością inwestycji wykorzystujących klasyczne metody doboru aktywów do portfela może być rozważana na płaszczyźnie teoretycznej oraz w świetle badań empirycznych. Badania teoretyczne koncentrują się wokół dogłębnej analizy założeń teorii portfelowej oraz implikacji, jakie oznaczają one dla portfela inwestycyjnego tworzonego w oparciu o strategię SRI. Empiryczna weryfikacja przedstawionego zagadnienia bazuje na danych rzeczywistych i może zostać przeprowadzona za pomocą czterech następujących metod:

- porównywania stóp zwrotu generowanych przez tradycyjne indeksy giełdowe ze stopami zwrotu z indeksów typu SRI;

- analizy porównawczej wyników funduszy inwestycyjnych deklarujących stosowanie SRI z osiągnięciami tradycyjnych funduszy inwestycyjnych;

- wykorzystania znanych modeli rynku kapitałowego do analizy stóp zwrotu generowanych przez portfele, w skład których wchodzą spółki odpowiedzialne społecznie oraz ich porównanie ze stopami zwrotu z portfela rynkowego lub portfeli budowanych metodami klasycznymi; 
- wykorzystania metod symulacyjnych w celu stworzenia losowych, hipotetycznych portfeli akcji spółek uznawanych za społecznie odpowiedzialne, a następnie porównanie ich efektywności z portfelami składającymi się $\mathrm{z}$ akcji dowolnych spółek.

W kontekście weryfikacji postawionej we wstępie niniejszego opracowania hipotezy badawczej, stanowiącej, że efektywność inwestycji opartych na SRI nie odbiega w sposób istotny od efektywności klasycznych strategii inwestycyjnych, niewątpliwie najwłaściwszym rozwiązaniem byłoby równoległe zastosowanie wszystkich wskazanych powyżej metod oraz kompleksowe zestawienie płynących $\mathrm{z}$ nich wniosków. Tak szeroko zdefiniowany zakres badawczy wykraczałby jednak poza ramy niniejszego opracowania, dlatego też zdecydowano się na wykorzystanie wyłącznie drugiej ze wskazanych metod, tj. przeprowadzenie analizy wyników inwestycyjnych osiąganych przez funkcjonujące w Polsce fundusze akcyjne deklarujące stosowanie SRI (por. tab. 1.) oraz porównanie ich z wynikami funduszy akcyjnych inwestujących w sposób tradycyjny².

Ta b e l a 1. Polskie fundusze SRI objęte badaniem

\begin{tabular}{|l|l|l|}
\hline \multicolumn{1}{|c|}{ Nazwa funduszu } & \multicolumn{1}{|c|}{ Skrót } & $\begin{array}{c}\text { Data } \\
\text { pierwszego } \\
\text { notowania }\end{array}$ \\
\hline SKOK SFIO Etyczny 2 (SKOK Parasol FIO) & SKOK 2 & $2010-08-18$ \\
\hline PZU Energia Medycyna Ekologia (PZU FIO Parasolowy) & PZU EME & $2007-12-20$ \\
\hline PKO Biotechnologii i Innowacji Globalny (Parasolowy FIO) & PKO BIG & $2010-04-07$ \\
\hline Investors zmian klimatycznych & INVESTORS ZK & 2008-01-28 \\
\hline
\end{tabular}

Źródło: opracowanie własne.

Opracowana, w celu weryfikacji postawionej we wstępie hipotezy, metodologia badań zakładała porównanie stóp zwrotu osiąniętych przez funkcjonujące w Polsce fundusze akcyjne deklarujące stosowanie SRI ze stopami zwrotu z benchmarku, który został zdefiniowany jako średnia stopa zwrotu

2 Niniejsze opracowanie stanowi fragment zakrojonych na szerszą skalę badań autora, w ramach których planowane jest wykorzystanie wszystkich wskazanych metod. Dotychczas opublikowane zostały wyniki porównania stóp zwrotu generowanych przez tradycyjne indeksy giełdowe ze stopami zwrotu z indeksu typu SRI. Z badań tych wynika, że efektywność inwestycji społecznie odpowiedzialnych mierzona za pomocą Respect Index nie wykazuje statystycznie istotnych różnic względem inwestycji w portfel szerokiego rynku, którego odbiciem jest indeks WIG (Jedynak 2012). 
z wybranych w sposób losowy 10 funduszy stosujących tradycyjne kryteria doboru spółek do portfela. Populację generalną, z której wylosowano fundusze do benchmarku stanowiło 78 funduszy, tj. fundusze akcyjne dostępne w Polsce, których jednostki uczestnictwa są notowane co najmniej od 1.01.2008 r., z wyłączeniem funduszy inwestujących w sektorze nieruchomości i sektorze surowców oraz wyłącznie na rynkach określanych jako wschodzące, rynkach azjatyckich, we wschodniej Europie, w Turcji lub w USA. Z populacji generalnej wyłączono również 4 fundusze SRI. Listę wylosowanych funduszy, w oparciu o które stworzono benchmark zawiera tabela 2. Zakres czasowy badania obejmował okres od 1.01.2008 do 31.12.2012 r. Stosunkowo krótki horyzont badania wynika z ograniczonej dostępności danych historycznych, która jest spowodowana krótkim okresem notowania jednostek uczestnictwa funduszy stosujących SRI - najdłużej obecny na polskim rynku fundusz SRI (PZU EME) notowany jest od dopiero od 20 grudnia $2007 \mathrm{r}$.

Ta b e la 2. Fundusze stanowiące podstawę opracowania benchmarku

\begin{tabular}{|l|c|}
\hline \multicolumn{1}{|c|}{ Nazwa funduszu } & $\begin{array}{c}\text { Data pierwszego } \\
\text { notowania }\end{array}$ \\
\hline Amplico Akcji Średnich Spółek (Krajowy FIO) & $2006-11-14$ \\
\hline UniAkcje Małych i Średnich Spółek (UniFundusze FIO) & $2007-09-20$ \\
\hline ING Akcji (ING FIO) & $1998-03-09$ \\
\hline Millennium Dynamicznych Spółek (Millennium FIO) & $2007-04-10$ \\
\hline Arka BZ WBK Funduszy Akcji Zagranicznych (Arka BZ WBK FIO) & $2006-05-30$ \\
\hline Skarbiec - Top Funduszy Akcji SFIO & $2005-02-14$ \\
\hline PKO Akcji FIO & $1998-01-27$ \\
\hline Allianz Akcji (Allianz FIO) & $2004-01-28$ \\
\hline UniAkcje: Nowa Europa (UniFundusze FIO) & $2006-06-22$ \\
\hline Investor Akcji Dużych Spółek FIO & $2006-06-22$ \\
\hline
\end{tabular}

Źródło: opracowanie własne.

W toku przeprowadzonych badań falsyfikacji poddane zostały wskazane poniżej hipotezy określone mianem pomocniczych.

$$
\begin{aligned}
& \mathrm{H}_{0}: r_{S R I}=r_{B}, \\
& \mathrm{H}_{1}: r_{S R I} \neq r_{B},
\end{aligned}
$$

gdzie $r_{S R I}$ oznacza średnią stopę zwrotu z funduszy deklarujących stosowanie SRI, a $r_{B}$ - średnią stopę zwrotu funduszy stosujących tradycyjne metody doboru spółek do portfela, którą w przeprowadzonym badaniu obra- 
zuje przyjęty benchmark. Za miarę osiąganego przez poszczególne fundusze dochodu przyjęto miesięczne stopy zwrotu, które zostały obliczone na podstawie dziennych zmian wartości jednostek uczestnictwa tych funduszy. W celu weryfikacji powyższej hipotezy zastosowano statystyczny test wartości przeciętnych dla dwóch prób niezależnych zakładający różne wariancje.

$$
\begin{aligned}
& \mathrm{H}_{0}: \sigma_{S R I}=\sigma_{B}, \\
& \mathrm{H}_{1}: \sigma_{S R I} \neq \sigma_{B},
\end{aligned}
$$

gdzie $\sigma_{S R I}$ - odchylenie standardowe stopy zwrotu z funduszy deklarujących stosowanie SRI, a $\sigma_{B}$ - odchylenie standardowe stóp zwrotu $\mathrm{z}$ funduszy tradycyjnych (benchmarku). W toku badania powyższa hipoteza została zweryfikowana statystycznym testem dla równości wariancji.

$$
\begin{aligned}
& \mathrm{H}_{0}: E_{S R I}=E_{B}, \\
& \mathrm{H}_{1}: E_{S R I} \neq E_{B},
\end{aligned}
$$

gdzie $E_{S R I}$ oznacza efektywność funduszy deklarujących stosowanie SRI, a $E_{B}$ - efektywność funduszy tradycyjnych (benchmarku). Efektywność w tym przypadku rozumiana jest jako relacja osiaganego zysku do ponoszonego ryzyka, a za jej miary przyjęto wywodzące się z klasycznej teorii portfelowej, wymienione poniżej, miary efektywności.

\section{Wskaźnik Treynora:}

$$
r_{p}=\alpha_{p}+B_{p} \times r_{m}+\varepsilon_{t},
$$

gdzie:

$r_{p}$ - stopa zwrotu z portfela $\mathrm{p}$,

$\alpha_{p}$ - wyraz wolny dla portfela $\mathrm{p}$,

$B_{p}$ - współczynnik beta portfela $\mathrm{p}$,

$r_{m}$ - stopa zwrotu z portfela rynkowego (indeks WIG),

$\varepsilon_{t}$ - składnik losowy portfela.

\section{Wskaźnik Sharpe'a:}

$$
S=\frac{r_{p-} r_{f}}{\sigma_{p}},
$$


gdzie:

$S$ - wskaźnik Sharpe'a,

$\sigma_{p}$ - odchylenie standardowe stóp zwrotu z portfela $\mathrm{p}$,

$r_{f}$ - stopa wolna od ryzyka (przyjęto stawkę WIBOR 1M).

Alfa Jensena:

$$
\alpha_{p}=r_{p}-\left(r_{f}+\beta_{p}\left(r_{m}-r_{f}\right)\right)+\varepsilon_{t},
$$

gdzie:

$\alpha_{p}$ - miernik alfa Jensena.

Współczynniki beta poszczególnych funduszy oraz benchmarku niezbędne do obliczenia wskaźnika Treynora oraz alfy Jensnena oszacowano, wykorzystując metodę najmniejszych kwadratów dla modelu jednowskaźnikowego:

$$
r_{f}=\alpha_{f}+\beta_{f} \times r_{m}+\varepsilon
$$

gdzie:

$r_{f}$ - stopa zwrotu z funduszu $f$,

$\alpha_{f}$ - wyraz wolny dla równania liniowego funduszu $f$,

$\beta_{f}$ - współczynnik beta inwestycji $f$,

$r_{m}$ - stopa zwrotu z portfela rynkowego (indeks WIG),

$\varepsilon$ - wyraz wolny równania, obrazujący czynnik losowy.

Ze względu na krótki horyzont badania uniemożliwiający wygenerowanie wystarczająco długiego szeregu danych, hipotezy 3 nie weryfikowano statystycznie, ograniczając się do bezpośredniego porównania uzyskanych miar efektywności w poszczególnych podokresach badawczych.

\section{Podsumowanie wyników badań}

Tabela 3 zawiera podstawowe statystyki opisujące uwzględnione w badaniu fundusze oraz benchmark w przyjętym horyzoncie czasowym. W celu uszczegółowienia analizy przedstawiono również dane za poszczególne podokresy. Ponadto $\mathrm{w}$ tabeli przedstawione zostały również wyniki testów Shapiro-Wilka oraz chi-kwadrat, za pomocą których zweryfikowano normalność rozkładów poszczególnych zmiennych. Weryfikacja normalności roz- 
kładu była konieczna ze względu na wykorzystanie w dalszej części badania parametrycznych testów dla wartości przeciętnych oraz testów dla równości wariancji.

Ta b e la 3. Średnie miesięczne stopy zwrotu oraz ich odchylenia standardowe dla badanych funduszy i benchmarku

\begin{tabular}{|c|c|c|c|c|c|c|c|}
\hline \multirow{2}{*}{ Fundusz } & \multirow{2}{*}{ Okres } & \multirow{2}{*}{$\begin{array}{c}\text { Średnia } \\
\text { miesięcz- } \\
\text { na stopa } \\
\text { zwrotu }\end{array}$} & \multirow{2}{*}{$\begin{array}{c}\text { Odchylenie } \\
\text { standardo- } \\
\text { we stopy } \\
\text { zwrotu }\end{array}$} & \multicolumn{4}{|c|}{ Normalność rozkładu } \\
\hline & & & & \begin{tabular}{|c|} 
statystyka W (test \\
Shapiro-Wilka)
\end{tabular} & p-value & $\begin{array}{c}\text { statystyka } \chi^{2} \text { (test } \\
\text { chi-kwadrat) }\end{array}$ & p-value \\
\hline \multirow{6}{*}{$\begin{array}{l}1 \\
\frac{1}{0} \\
\frac{1}{\infty}\end{array}$} & 2008 & - & - & \multirow{6}{*}{0,9831} & \multirow{6}{*}{0,9164} & \multirow{6}{*}{1,7917} & \multirow{6}{*}{0,1807} \\
\hline & 2009 & - & - & & & & \\
\hline & $2010^{*}$ & $1,36 \%$ & 0,0232 & & & & \\
\hline & 2011 & $-2,03 \%$ & 0,0325 & & & & \\
\hline & 2012 & $1,64 \%$ & 0,0405 & & & & \\
\hline & 2010-2012 & $0,03 \%$ & 0,0398 & & & & \\
\hline \multirow{6}{*}{ 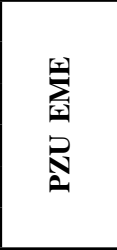 } & 2008 & $-0,39 \%$ & 0,0264 & \multirow{6}{*}{0,9707} & \multirow{6}{*}{0,1586} & \multirow{6}{*}{4,9279} & \multirow{6}{*}{0,4247} \\
\hline & 2009 & $-0,64 \%$ & 0,0222 & & & & \\
\hline & 2010 & $1,56 \%$ & 0,0284 & & & & \\
\hline & 2011 & $2,12 \%$ & 0,0227 & & & & \\
\hline & 2012 & $0,48 \%$ & 0,0126 & & & & \\
\hline & $2008-2012$ & $0,60 \%$ & 0,0255 & & & & \\
\hline \multirow{6}{*}{$\begin{array}{l}0 \\
0 \\
0 \\
0 \\
0\end{array}$} & 2008 & - & - & \multirow{6}{*}{0,9814} & \multirow{6}{*}{0,8380} & \multirow{6}{*}{0,7947} & \multirow{6}{*}{0,3727} \\
\hline & 2009 & - & - & & & & \\
\hline & $2010^{*}$ & $1,21 \%$ & 0,0237 & & & & \\
\hline & 2011 & $-0,60 \%$ & 0,0298 & & & & \\
\hline & 2012 & $0,33 \%$ & 0,0277 & & & & \\
\hline & 2010-2012 & $0,20 \%$ & 0,0289 & & & & \\
\hline \multirow{6}{*}{ 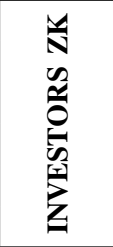 } & 2008 & $-4,52 \%$ & 0,0819 & \multirow{6}{*}{0,8891} & \multirow{6}{*}{0,0001} & \multirow{6}{*}{4,5999} & \multirow{6}{*}{$0,0319^{\prime}$} \\
\hline & 2009 & $1,71 \%$ & 0,0477 & & & & \\
\hline & 2010 & $0,02 \%$ & 0,0312 & & & & \\
\hline & 2011 & $-2,11 \%$ & 0,0367 & & & & \\
\hline & 2012 & $0,06 \%$ & 0,0265 & & & & \\
\hline & 2008-2012 & $-0,85 \%$ & 0,0525 & & & & \\
\hline \multirow{6}{*}{ 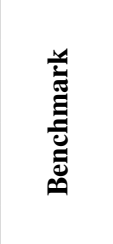 } & 2008 & $-6,04 \%$ & 0,0662 & \multirow{6}{*}{0,9448} & \multirow{6}{*}{0,0090} & \multirow{6}{*}{3,1773} & \\
\hline & 2009 & $2,98 \%$ & 0,0602 & & & & \\
\hline & 2010 & $1,31 \%$ & 0,0314 & & & & \\
\hline & 2011 & $-1,73 \%$ & 0,0398 & & & & $0,0 / 47$ \\
\hline & 2012 & $1,28 \%$ & 0,0313 & & & & \\
\hline & $2008-2012$ & $-0,35 \%$ & 0,0570 & & & & \\
\hline
\end{tabular}

* Dane obejmują niepełny rok.

Źródło: opracowanie własne. 
Statystyczna weryfikacja hipotezy (1), wykazała iż w przypadku żadnego $z$ badanych funduszy stosujących SRI nie ma podstaw do odrzucenia hipotezy zerowej stanowiącej, że przeciętna stopa zwrotu osiągana przez fundusze stosujące SRI nie różni się od stopy zwrotu osiąganej przez fundusze stosujące tradycyjne strategie inwestycyjne (por. tab. 4).

Wyniki weryfikacji hipotezy (2) nie są równie jednoznaczne, jak w przypadku hipotezy (1). Na poziomie istotności $\alpha=0,05 \mathrm{w}$ przypadku jednego $z$ badanych funduszy (INVESTORS ZK) nie stwierdzono występowania statystycznie istotnej różnicy pomiędzy jego wariancją a wariancją benchmarku. Z kolei w przypadku trzech pozostałych funduszy (SKOK 2, PZU EME, PKO BIG) wystąpiły statystycznie istotne różnice, pozwalające odrzucić hipotezę zerową mówiącą, że mierzone wariancją stopy zwrotu ryzyko inwestycyjne funduszy stosujących SRI jest równe ryzyku ponoszonemu przez fundusze w benchmarku.

Ta b e l a 4. Porównanie średnich stóp zwrotu i wariancji z wybranych funduszy SRI oraz benchmarku

\begin{tabular}{|l|c|c|c|c|c|}
\hline & Liczba obserwacji & Statystyka t & p-value & Statystyka F & p-value \\
\hline SKOK 2 & 28 & 0,3158 & 0,7529 & 2,0091 & 0,0492 \\
\hline PZU EME & 60 & 1,1688 & 0,2448 & 5,0009 & 0,0000 \\
\hline PKO BIG & 32 & 0,5083 & 0,6125 & 3,8187 & 0,0001 \\
\hline INVESTORS ZK & 59 & $-0,4954$ & 0,6213 & 1,1763 & 0,5371 \\
\hline
\end{tabular}

Źródło: opracowanie własne.

Podstawowe miary efektywności inwestycji dla badanych funduszy oraz benchmarku zostały zaprezentowane w tabeli 5 .

$\mathrm{Z}$ przedstawionych $\mathrm{w}$ tabeli 5 danych wynika, że w przyjętym okresie badawczym współczynniki beta dla poszczególnych funduszy deklarujących SRI były niższe od analogicznego współczynnika dla benchmarku. Oznacza to, że badane fundusze SRI w mniejszym stopniu narażone były na ryzyko systematyczne. Ze względu na krótki okres badania, uwzględnione w badaniu miary efektywności inwestycji oparte na modelu CAPM nie pozwalają natomiast na sformułowanie jednoznacznych wniosków w zakresie efektywności strategii SRI. Wartości wskaźników Sharpe'a i Treynora oraz alfy Jensena w poszczególnych latach nie wykazują zauważalnych prawidłowości. W okresie 2010-2012 miara Sharpe'a oraz alfa Jensena jednego funduszu SRI (PZU EME) były wyższe od benchmarku. Również w okresie 2008-2012 
Ta b e l a 5. Wskaźniki efektywności dla badanych funduszy SRI i benchmarku

\begin{tabular}{|c|c|c|c|c|c|}
\hline Fundusz & Okres & Beta & $\begin{array}{l}\text { Wskaźnik } \\
\text { Treynora }\end{array}$ & $\begin{array}{l}\text { Wskaźnik } \\
\text { Sharpe'a } \\
\end{array}$ & Alfa Jensena \\
\hline \multirow[t]{7}{*}{ SKOK 2} & 2008 & - & - & - & - \\
\hline & 2009 & - & - & - & - \\
\hline & 2010 & - & - & - & - \\
\hline & 2011 & 0,6124 & $-0,0391$ & $-0,7359$ & $-0,0110$ \\
\hline & 2012 & 0,9109 & 0,0137 & 0,3079 & $-0,0027$ \\
\hline & 2010-2012 & 0,7711 & $-0,0045$ & $-0,0871$ & $-0,0004$ \\
\hline & 2008-2012 & - & - & - & - \\
\hline \multirow[t]{7}{*}{ PZU EME } & 2008 & 0,2030 & $-0,0506$ & $-0,3887$ & - \\
\hline & 2009 & 0,1755 & $-0,0541$ & $-0,4280$ & - \\
\hline & 2010 & $0,2764^{*}$ & 0,0455 & 0,4505 & 0,0091 \\
\hline & 2011 & $-0,2817$ & $-0,0621$ & 0,7710 & 0,0116 \\
\hline & 2012 & $0,0243^{*}$ & 0,0330 & 0,0635 & 0,0004 \\
\hline & 2010-2012 & $-0,1084^{*}$ & $-0,0949$ & 0,4467 & \\
\hline & 2008-2012 & $\mathbf{0 , 1 0 3 2}$ & $\mathbf{0 , 0 2 1 5}$ & 0,0870 & 0,0026 \\
\hline \multirow[t]{7}{*}{ PKO BIG } & 2008 & - & - & - & - \\
\hline & 2009 & - & - & - & - \\
\hline & 2010 & - & - & - & - \\
\hline & 2011 & 0,5293 & $-0,0183$ & $-0,3250$ & 0,0015 \\
\hline & 2012 & 0,4544 & $-0,0014$ & $-0,0230$ & $-0,0082$ \\
\hline & 2010-2012 & 0,4523 & $-0,0039$ & $-0,0608$ & 0,0000 \\
\hline & 2008-2012 & - & - & - & - \\
\hline \multirow[t]{7}{*}{ INVESTORS ZK } & 2008 & - & - & - & - \\
\hline & 2009 & $0,2772^{*}$ & 0,0504 & 0,2925 & 0,0050 \\
\hline & 2010 & 0,5489 & $-0,0051$ & $-0,0858$ & $-0,0097$ \\
\hline & 2011 & 0,5805 & $-0,0427$ & $-0,6757$ & $-0,0125$ \\
\hline & 2012 & $0,3360^{*}$ & $-0,0101$ & $-0,1280$ & $-0,0090$ \\
\hline & 2010-2012 & 0,5075 & $-0,0203$ & $-0,3053$ & $-0,0117$ \\
\hline & 2008-2012 & $\mathbf{0 , 5 3 2 3}$ & $-0,0231$ & $-0,2342$ & $-0,0102$ \\
\hline \multirow[t]{7}{*}{ Benchmark } & 2008 & 0,7860 & $-0,0777$ & $-0,9223$ & $-0,0136$ \\
\hline & 2009 & 0,6613 & 0,0403 & 0,4427 & 0,0053 \\
\hline & 2010 & 0,7014 & 0,0144 & 0,3091 & 0,0014 \\
\hline & 2011 & 0,7974 & $-0,0263$ & $-0,5277$ & $-0,0042$ \\
\hline & 2012 & 0,6965 & 0,0127 & 0,2827 & $-0,0028$ \\
\hline & 2010-2012 & 0,7478 & $-0,0009$ & $-0,0180$ & $-0,0027$ \\
\hline & 2008-2012 & 0,7669 & $-0,0095$ & $-0,1278$ & $-0,0042$ \\
\hline
\end{tabular}

* Bety statystycznie nieistotne.

Źródło: opracowanie własne. 
PZU EME okazał się lepszy od benchmarku. Powyższe stwierdzenia nie upoważniają jednak do wysunięcia na ich podstawie jakichkolwiek uogólnień.

\section{Wnioski}

W opracowaniu analiza porównawcza wyników funduszy inwestycyjnych deklarujących stosowanie SRI z wynikami uzyskiwanymi przez fundusze stosujące klasyczne metody doboru aktywów do portfela została przeprowadzona na trzech płaszczyznach stanowiących określone we wstępie zadania badawcze. Przeprowadzone badania wykazały, że przeciętna stopa zwrotu osiągana przez fundusze deklarujące stosowanie strategii SRI w przyjętym okresie badawczym nie różniła się istotnie od przeciętnej stopy zwrotu osiąganej przez fundusze stosujące tradycyjne strategie inwestycyjne. Wykazano również, że w przypadku trzech z czterech badanych funduszy SRI, wariancja ich stopy zwrotu była statystycznie różna od wariancji stopy zwrotu z przyjętego benchmarku. Wynik taki może sugerować, że fundusze SRI charakteryzują się niższym ryzykiem od funduszy tradycyjnych. Analiza miar efektywności opartych na modelu CAPM dla poszczególnych funduszy oraz benchmarku, ze względu na krótki horyzont badania, nie przyniosła jednoznacznych rezultatów, nie dając tym samym podstaw do weryfikacji postawionej hipotezy. Podsumowując zatem przeprowadzone badania stwierdza się, że ich rezultat nie dostarcza wystarczających podstaw do odrzucenia hipotezy stanowiącej, iż efektywność inwestycji opartych na SRI jest zbliżona do efektywności klasycznych strategii inwestycyjnych.

\section{Bibliografia}

Bauer, R., Derwall, J. i Otten R. (2007). The Ethical Mutual Fund Performance Debate: New Evidence from Canada, Journal of Business Ethics, 70(2). Doi: 10.1007/s10551-006-9099-0.

Bello, Z. (2005). Socially Responsible Investing and Portfolio Diversification, Journal of Financial Research, 28(1), 41-57. Doi: 10.1111/j.1475-6803.2005.00113.x.

Czerwińska, T. (2009). Społeczna odpowiedzialność polityki inwestycyjnej funduszy emerytalnych, Wiadomości Ubezpieczeniowe, 3, 11-27.

Czerwonka, M. (2013). Inwestowanie spotecznie odpowiedzialne. Warszawa: Difin.

Derwall, J., Gunster, N., Bauer, R. i Koedijk, K. (2005). The Eco-Efficiency Premium Puzzle, Financial Analysts Journal, 61(2), 51-63. Doi: 10.2469/faj.v61.n2.2716.

Domini, A. i Kinder, P. (1984). Ethical Investment. New York: Addison-Wesley.

Geczy, C., Stambaugh, R. i Levin, D. (2003). Investing in Socially Responsible Mutual Funds, SSRN Electronic Journal. Doi: 10.2139/ssrn.416380. 
Gregory, A., Matako, J. i Luther, R. (1997). Ethical unit trust financial performance: Small company effects and fund size effects, Journal of Business Finance and Accounting, 24(5), 705-725. Doi: 10.1111/1468-5957.00130.

Jedynak, T. (2011). Kontrowersje wokół efektywności inwestycji społecznie odpowiedzialnych, Zeszyty Naukowe Polskiego Towarzystwo Ekonomicznego, 11, 237-252.

Jedynak, T. (2011a). Rozwój koncepcji inwestowania społecznie odpowiedzialnego w Polsce i na świecie, Zeszyty Naukowe Uniwersytetu Ekonomicznego w Krakowie. Seria Finanse, $875,17-28$.

Jedynak, T. (2012). Efektywność strategii inwestycji w akcje spółek społecznie odpowiedzialnych na przykładzie Respect Index, Zeszyty Naukowe Polskiego Towarzystwa Ekonomicznego, 12, 161-172.

Kaźmierkiewicz, P. (2010). Analiza atrakcyjności inwestycji w spółki odpowiedzialne społecznie (SRI) na podstawie rankingu Global100, E-Finanse. Finansowy kwartalnik internetowy, 6, 28-45.

Langbein, J. H. i Posner, R.H. (1980). Social Investing and the Law of Trusts, Michigan Law Review, 72. Doi: 10.2307/1288337.

Urban, D. (2011). Zarys koncepcji inwestowania społecznie odpowiedzialnego, Acta Universitatis Lodziensis, Folia Oeconomica, 261, 495-505.

World Economic Forum (2005). Mainstream responsible investing, Geneva, World Economic Forum. Pozbrano z: http://www.accountability.org/images/content/3/1/316/Mainstreaming\%20Responsible\%20Investment.pdf (20.10.2013). 
ISBN 978-83-63962-51-7 